\title{
Strategien der Desorientierung in der postmodernen Prosa
}

\author{
Thomas Pynchons The Crying of Lot 49 \\ Elfriede Jelineks Lust \\ Witold Gombrowicz‘ Kosmos
}

\begin{abstract}
Dissertation
zur Erlangung des philosophischen Doktorgrades

an der Philosophischen Fakultät der Georg-August-Universität Göttingen
\end{abstract}

\author{
vorgelegt von \\ Kamil Siwiec \\ aus Toruń, Polen
}

Göttingen 2016 


\section{Inhaltsverzeichnis}

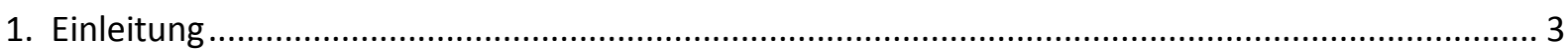

2. Reflexion über die Postmoderne - eine Dauerbaustelle.............................................................. 8

2.1. Friedrich Nietzsche - der Vorläufer par excellence der Postmoderne ................................... 17

2.2. Jürgen Habermas' Konsens vs. Jean-François Lyotards Dissens oder der, einzig wahre' Streit

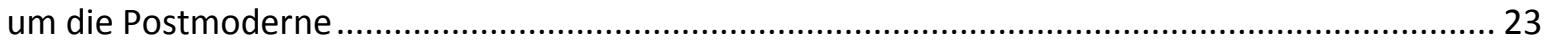

2.3. Postmoderne - das Zeitalter der permanenten Ästhetisierung............................................. 29

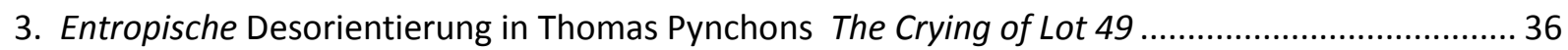

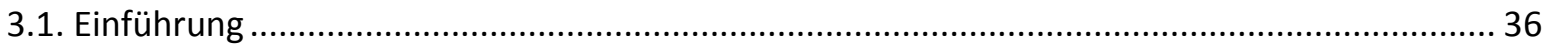

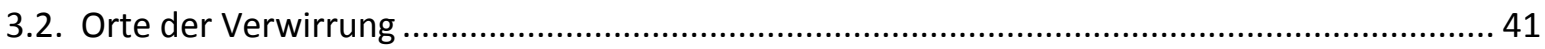

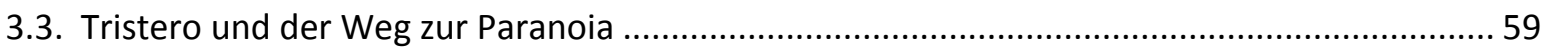

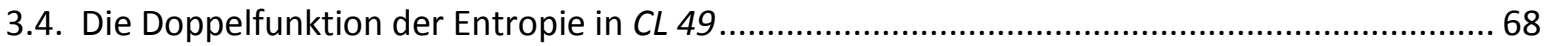

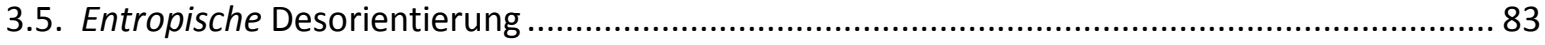

4. Hyper-Subversive Desorientierung in Elfriede Jelineks Lust ......................................................... 88

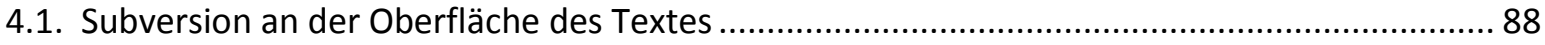

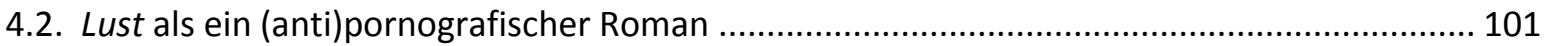

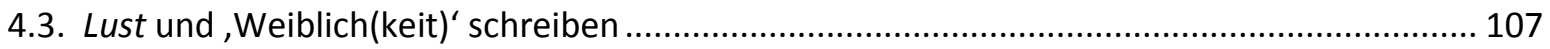

5. Unheimliche Desorientierung in Witold Gombrowicz' Kosmos .................................................. 124

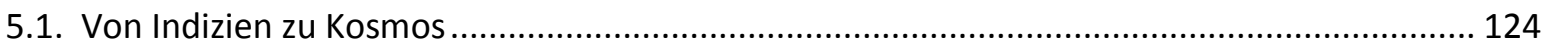

5.2. Vom Spatz zu den Mündern oder die Welt mit Unheimlichkeit unternäht ............................ 130

5.2.1. Das Unheimliche im Kontext der Psychoanalyse .......................................................... 138

5.2.2. Die verwirrende Unheimlichkeit der Selbstigkeit.............................................................. 150

5.3. Vom Erdklümpchen zum Regenguss - ein Laboratorium des Bewusstseins ......................... 159

5.4. Exkurs: Philosophische (Meta)Desorientierung im Kontext der Kosmos-Lesarten ................. 174

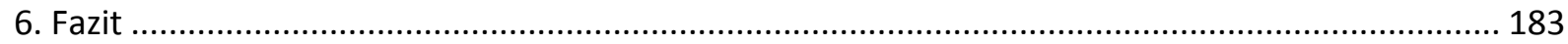

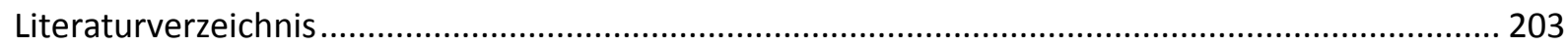




\section{Einleitung}

Durch den Einsatz einer Strategie erwartet (bzw. erhofft man) das effiziente Erreichen eines Ziels, auf dem Weg zu dem die Involvierten von der Strategie gelenkt werden. Somit weist jedes strategische Vorgehen manipulatorische Züge auf. Der Zustand der Desorientierung scheint sich an Orten zu konstituieren, an denen der Rezipient die Klarheit und ein ungestörtes Gefühl der (guten) Orientierung besitzt. ${ }^{1}$ Der desorientierte Leser wird vor die Notwendigkeit gestellt, seine Erwartungen zu verwerfen oder wenigstens in Frage zu stellen, die ihm vertrauten Strategien der Sinnstiftung zu hinterfragen oder die Lektüre abzubrechen. Unter ,Desorientierung' verstehe ich den Zustand der Unmöglichkeit, sich während der Sinnkonstituierung ${ }^{2}$ der Textfragmente und folglich des Textganzen eines literarischen Werkes der Diskursivität ${ }^{3}$ zu bedienen. Die Desorientierung konstituiert sich als Folge der Verdichtung von Verwirrungen, deren Zahl und/oder Art und Weise die Lektüre in erster Linie punktuell stören. Es kann dabei nicht ausgeschlossen werden, dass ein literarischer Text den Leser angesichts der Anhäufung von Verwirrungen schon nach einer kurzen Lektüre desorientiert. Oft wird die Desorientierung ontologisch und/oder epistemologisch fundiert, d.h. es bleibt unklar, welcher Art Entitäten die Protagonisten begegnen und auf welchen Wegen sie zur Erkenntnis kommen. Desorientierend kann auch ein Insistieren auf das Vorhandensein einer Realität/Dimension wirken, bei gleichzeitiger explizit thematisierter Unmöglichkeit des Ausdrucks dieser Realität. Die strategische Desorientierung in einem literarischen Text kann sowohl mit der Konturierung der Gegenstände oder Personen

\footnotetext{
${ }^{1} \mathrm{Vgl}$. Andrzej Zalewski: Strategiczna dezorientacja. Perypetie rozumu w postmodernistycznym filmie fabularnym. [Strategische Desorientierung. Peripetien der Vernunft im postmodernen Spielfilm], Warszawa 1998, S.7. Zalewskis Auseinandersetzung wurde für mich zum Hauptanreiz für mein Dissertationsvorhaben. Sein Buch, das die strategische Desorientierung in Spielfilmen diagnostiziert und exploriert, machte mich darauf neugierig, ob sich bei diesem Phänomen Parallelen mit der postmodernen Literatur finden lassen. (Alle Übersetzungen aus dem Polnischen stammen von mir.)

${ }^{2}$ In seiner innerhalb der philosophischen Logik fundierten Unterscheidung zwischen ,Sinn' und ,Bedeutung' betont Frege, dass selbst dann, wenn man schon einen „Sinn auffaßt, hat man noch nicht mit Sicherheit eine Bedeutung." Gottlob Frege, Über Sinn und Bedeutung. In: Ders. Funktion, Begriff, Bedeutung. Fünf logische Studien. Hrsg. von Günther Patzig, Göttingen 2008, S. 25. Freges einleuchtende Bemerkungen wären sicherlich unentbehrlich, wenn man die Untersuchung eines literarischen Textes aus der philosophischen Perspektive betrachten möchte. Die Fregesche ,Bedeutung' entspricht im heutigen Gebrauch dem Begriff der ,Referenz' und ,Sinn' wird mit ,Bedeutung' übersetzt. Vgl. Peter Prechtl, Franz-Peter Burkard (Hg.), Metzler Philosophie Lexikon. Begriffe und Definitionen. Stuttgart-Weimar 1999, S. 61. Da in meiner Arbeit die Referenz als Problem nicht thematisiert wird, gebrauche ich die Begriffe ,Sinn' und, Bedeutung' synonymisch.

${ }^{3}$ Unter ,Diskursivität' verstehe ich „ein methodisch strukturiertes und begriffliches Denken [sowie] eine rein argumentativ aufgebaute Begründungsweise.“ Peter Prechtl, Franz-Peter Burkard (Hg.), a.a.O., S. 115. „Das diskursive Denken ist im Gegensatz zur intuitiven Erkenntnis von jedem nachvollziehbar." Alexander Ulfig, Lexikon der philosophischen Begriffe. Wiesbaden 1997, S. 91.
} 
als auch mit der Art und Weise, wie das Geschehen erzählt wird, zu tun haben. Selten wurde in der nachmodernen Literatur die Strategie des „Konstruieren[s] von Objekten (ihrer Sammlungen oder Umwelten), die von Anfang an seltsam sind“4 Beispiele finden wir aber in den Romanen von Boris Vian. ${ }^{5}$ Die andere - die sozusagen nicht gegenstandsbasierte Strategie der Desorientierung - zielt darauf, das Wahrnehmen des Rezipienten von dem Gegenstand oder der Person zu lösen und seine Aufmerksamkeit auf die ungewöhnliche Art des Erzählens zu lenken. In beiden Fällen soll die herkömmliche Lesbarkeit des Textes, d.i. die gewohnte Dekodierbarkeit der Bedeutung de(kon)struiert werden. Mit der Frage der Lesbarkeit müssen weiter die Sinnhaftigkeit der Erzählung und ihre mehr oder weniger radikale (Zer)Störung sondiert werden. Wird es aber immer möglich sein, die Stellen im Text aufzuzeigen, an denen der Sinn aufhört, diskursiv entschlüsselbar, explizierbar, erklärbar zu sein? Kann vielleicht die Sinnstiftung in den verschiedenen Annäherungen an den Text anders verlaufen? Kann sich das auf den ersten Blick Seltsame und Unklare im Text durch eine tiefere Betrachtung, durch ein Bohren im Text als (teilweise) klar erweisen? Alle drei Fragen würde ich bejahen. Die Antworten auf die erste Frage liefern meine Analysen der drei postmodernen Romane. Die zweite muss mit einer Anmerkung versehen werden. Zu Recht betont Zalewski, dass

„das Dechiffrieren der Geheimnisse der Texte keineswegs der erste und früheste Level des Umgangs mit ihm ist. Die Lektüre fängt nicht an mit einer Analyse oder mit hermeneutischen Prozeduren der Aufhellung des Sinns der Symbole, die im Text enthalten sind. Sie startet mit den wesentlich einfacheren Tätigkeiten des passiven Sich-Aneignens des Inhalts des Textes $[\ldots]^{\text {‘6 }}$

Somit gemeint (und hier untersucht) wird die primäre Desorientierung, die mit der ersten sozusagen spontanen - Lektüre verbunden ist. Es ist zwar wahrscheinlich, dass das anfängliche Überrascht- oder Verwirrt-Sein mit dem tieferen Ergründen des Textes behoben wird $^{7}$, die möglichen Verläufe solcher intensivierten Betrachtungen könnten jedoch wegen ihrer Beliebigkeit schwer analysiert werden.

\footnotetext{
${ }^{4}$ Ebd., S.17 [„,konstruowanie obektów (ich zbiorów, czy też środowisk) od początku niezwykłych.”]

${ }^{5}$ Es war Leslie A. Fiedler, der in seinem berühmten Aufsatz Überquert die Grenze, schließt den Graben! Boris Vian für einen der ersten postmodernen Schriftsteller erklärte. Vgl. In: Wolfgang Welsch (Hg.), Wege aus der Moderne, Weinheim 1988, S. 61.

${ }^{6}$ Andrzej Zalewski, a.a.O., S.42. [„,deszyfracja zagadek tekstu nie jest bynajmniej pierwszym i najwcześniejszym poziomem obcowania z nim. Lektura nie zaczyna się od analizy, czy, przykładowo, od hermeneutycznych procedur wyświetlania sensu symboli zawartych w tekście (...)"]

${ }^{7}$ Vgl. ebd., S.53.
} 
Literaturgeschichtlich beschränkt sich meine Untersuchung auf die Literatur der Postmoderne, die als Zeitalter der radikalen Pluralisierung und Fragmentierung sowie permanenten Ästhetisierung ${ }^{8}$ aller kulturellen Bereiche gekennzeichnet ist. In der Entgrenzung des Ästhetischen sehe ich ein Novum, das paradigmatische Wenden in allen Geisteswissenschaften und Künsten eingeleitet hat. Das Literarästhetische verstehe ich grundsätzlich als keine Elementqualität, ,sondern [als] eine Qualität der Relation zwischen den Textkonstituenten, zwischen Konstituenten und Text und zwischen Text(konstituenten) und Rezipienten." ${ }^{9}$ Die Strategien der Entgrenzung des Ästhetischen in postmodernen Romanen zu sondieren und einige ihrer Konsequenzen für die Lektüre zu beschreiben, ist Ziel dieser Arbeit. Die Hauptthese dieser Abhandlung ließe sich wie folgt formulieren: Der Effekt der Desorientierung entsteht als Resultat wiederholter Versuche der Ästhetisierung von Phänomenen, die literarästhetisch undarstellbar oder kaum darstellbar sind. Es wird behauptet, die Desorientierung sei mit der Entgrenzung des Sprachästhetischen verbunden. ${ }^{10}$

Die Lokalisierung und Einschätzung des Desorientierungspotentials in den untersuchten Romanen werden in der narratologischen Perspektive situiert. Zur Rekonstruktion der narrativen Kommunikation wird die Instanz des Modell-Lesers angenommen, konzipiert als „ein anthropomorphes Konstrukt, das gekennzeichnet ist durch die Kenntnis aller einschlägigen Codes und auch über alle notwendigen Kompetenzen verfügt, um die vom Text erforderten Operationen erfolgreich durchzuführen. “11 In dieser text- und leserorientierten Einstellung werden die Verfahren der Entgrenzung des Literarästhetischen sowie die Konsequenzen, wie sie die Sinnstiftung beeinflussen, untersucht.

\footnotetext{
${ }^{8}$ Eine gut fundierte Auseinandersetzung mit dem Problem der (insbesondere postmodernen) Ästhetisierung liefert Wolfgang Welsch im Buch Grenzgänge der Ästhetik, Stuttgart 1996. Einige seiner Thesen werden im letzten Teil dieser Dissertation angeführt und kritisch reflektiert. In meinen Analysen verstehe ich , Ästhetisierung' im Allgemeinen als eine intensive und/oder exzessive Affirmation der Textoberfläche.

${ }^{9}$ Siegfried J. Schmidt, Ästhetische Prozesse: Beiträge zu einer Theorie der nicht-mimetischen Kunst und Literatur, Kiepenheuer \& Witsch, Köln 1971, S. 172.

${ }^{10}$ Eine andere Ästhetisierung, nämlich die Ästhetisierung der Motivation wird nach Zalewski für die filmische Desorientierung verantwortlich. Was im postmodernen Film neu ist, ist die teilweise Auflösung der kausalen Motivation, die in früheren Filmen jeder Devianz zu Grunde lag. In der Postmoderne wird es oft die ästhetische Motivation sein, die eine völlig neue Strategie der Darstellung bedeutet, bei der es nicht mehr um das Motivieren der Folgen von irgendetwas geht. Die ästhetische Motivation betont den Wert der Künstlichkeit, hebt die Seltsamkeit der kreierten Welt hervor und erzwingt dadurch das Hinterfragen der angewohnten Wahrnehmungsweise. Vgl. ebd., S. 68 u. 76.

${ }^{11}$ Fotis Jannidis, Figur und Person. Beitrag zu einer historischen Narratologie, Berlin New York 2004, S.31. Der Begriff des Modell-Lesers lässt sich nach Jannidis weiter differenzieren. Als gelungen nennt er die Idee von Peter Rabinowitz, der „zwischen dem realen Publikum (actual audience), dem auktorialen Publikum (authorial audience), dem narrativen Publikum (narrative audience) und dem idealen narrativen Publikum (ideal narrative audience)" unterscheidet. Ebd., S.32. Jannidis macht darauf aufmerksam, dass Modell-Leser kein Textkonstrukt, sondern ein textbasiertes Konstrukt ist.
} 
Analysiert werden drei Romane: Thomas Pynchons The Crying of Lot 49, Elfriede Jelineks Lust und Witold Gombrowicz' Kosmos (zwei deutsche Ausgaben, die erste als Indizien, die zweite als Kosmos). Das älteste Werk ist der 1965 erschienene Kosmos, 1966 wurde Pynchons Roman veröffentlicht, Jelineks Buch erschien 1989. Mein Ziel war es, die Prosa bekannter SchriftstellerInnen auszuwählen, zu deren Werken bereits eine umfangreiche Forschungsliteratur erarbeitet wurde, die kritisch reflektiert und ergänzt werden könnte. Die Romane Pynchons und Gombrowicz‘ repräsentieren darüber hinaus m.E. eine sich erst konstituierende literarische Postmoderne. Ließe sich nämlich das Postmodern-Sein im Sinne der Radikalität, mit der die Aufklärungspotentiale der Moderne verworfen werden, skalieren, so ist Lust am intensivsten postmodern. Jelineks programmatische ,Seichtheit ${ }^{6}$ und Beseitigung aller Spuren individueller Subjektivität liefern ein Beispiel der extremen Ästhetisierung, nach deren Vollzug nur noch die Körper und ihre chaotischen Bewegungen auf der Oberfläche protokolliert werden können. Pynchon und Gombrowicz behalten noch die restlichen Bestandteile eines Subjekts, sondierend und erkundend zugleich, wie dieses unter der Invasion des (ästhetisierten und fragmentierten) Körpers schwächelt und den Prozess seiner eigenen Auflösung in Gang setzt. Das Abgleiten des Bewusstseins ihrer Protagonisten in die Paranoia illustriert deutlich, dass die modernen Strategien der Sinnstiftung bereits ausgedient haben und durch neue - noch nicht ausgearbeitete - ersetzt werden müssen. Bei Pynchon und Gombrowicz lässt sich meines Erachtens somit sehr gut die schrittweise verlaufende Entgrenzung des Ästhetischen beobachten, während sie bei Jelinek ihren Endzustand erreicht zu haben scheint.

Die Intensität des Postmodern-Seins ist auch unter den Literaturwissenschaftlern im Falle der Romane Pynchons und Gombrowicz' umstritten. Pynchon gilt zwar im Allgemeinen als ein nachmoderner Autor, seine ersten Romane (darunter auch The Crying of Lot 49) werden jedoch von Brian McHale als spätmodern eingestuft. ${ }^{12}$ Ähnlich verhält es sich mit Gombrowicz: Włodzimierz Bolecki etikettiert den Kosmos-Autor als durchaus modern und Zdzisław Łapiński ${ }^{13}$ sieht in ihm die Verkörperung des postmodernen Geistes. In beiden Fällen möchte ich einen Kompromiss vorschlagen und beide Romane als ,Grenztexte` an der Schnittstelle zwischen Moderne und Postmoderne situieren. Ich werde versuchen zu zeigen, dass sowohl The Crying of Lot 49 als auch Kosmos eine Reihe von mutigen und dezidierten

\footnotetext{
${ }^{12}$ Vgl. Brian McHale, Postmodernist Fiction, London and New York 1987, S. $23 f$.

${ }^{13}$ Die Schwierigkeit der eindeutigen Zuschreibung Gombrowicz' zur Moderne oder Postmoderne beruht im Kontext dieses ,Streits' darauf, dass beide Argumentationen als sinnvoll erscheinen. Vgl. Włodzimierz Bolecki, Polowanie na postmodernistów, Kraków 1999, S. 48-59 und Zdzisław Łapiński, Postmodernizm - co to i po co? [Die Postmoderne - Was ist das und wozu?] In: Teksty Drugie [Zweite Texte] Nr.1 (1993), S. 79 u. 81.
} 
Erkundungen im Bereich der Postmoderne absolviert haben. Es mag sein, dass sie noch auf den Posten der Moderne zurückgekehrt sind, in Gedanken, d.h. zwischen den Zeilen, sind sie jedenfalls irgendwo anders. Wo genau, das möchte ich hiermit herausfinden.

In der folgenden Reflexion über die Postmoderne möchte ich aus der Fülle der dem Abschied von der Moderne gewidmeten Ansätze diejenigen herauspicken, die sich ideen- und literaturgeschichtlich als am fruchtbarsten erwiesen. Thematisiert wird dabei die aporetische Beziehung der Postmoderne zur Moderne (bzw. zum Modernismus) mit dem Ziel, eine provisorische literaturgeschichtsorientierte Grenze zwischen den beiden Problematiken ${ }^{14} \mathrm{zu}$ ziehen. Um die Quelle der Wendung zum Ästhetischen, das in der Postmoderne vehement affirmiert wird, lokalisieren zu können, wird das nächste Unterkapitel dem wichtigsten Vorläufer der Nachmoderne - Friedrich Nietzsche gewidmet. Es wird unter anderem gezeigt, wie vielschichtig sich die Ideen des Autors von Ecce homo entfalten konnten, es wird aber auch auf die Grenzen der Vereinnahmung Nietzsches intellektuellen Erbes von den Postmodernen hingewiesen. Der in dem darauf folgenden Unterkapitel thematisierte ,Streit“ um die Postmoderne skizziert kurz zwei starke intellektuelle Positionen, die das Aufklärungspotential der Moderne sehr unterschiedlich einschätzen und mit der Geburt der neuen Epoche völlig verschiedene Erwartungen verbinden. Die Affirmation des Dissenses, die Lyotards Texte propagieren, läuft mit der generellen Ästhetisierung der Postmoderne ineinander, radikalisiert sie und fördert m.E. die Entgrenzung des Ästhetischen. Dem Prozess der permanenten Ästhetisierung widme ich das letzte einführende Unterkapitel. Die kurze Skizzierung der Dimension und der Mechanismen dieses Phänomens bildet die direkte Einleitung zur Untersuchung der von mir gewählten Romane.

\footnotetext{
${ }^{14}$ Vgl. Peter V. Zima, Moderne/Postmoderne: Gesellschaft, Philosophie, Literatur. Tübingen Basel 2001, S. 37. Vorsichtig und m. E. einleuchtend verzichtet Zima darauf, Moderne, Modernismus und Postmoderne als ,Ideologien, Weltanschauungen oder rivalisierende Ästhetiken' zu denken: „Sie sind eher als gesellschaftliche und historische Problematiken aufzufassen: als sozio-linguistische Situationen, in denen bestimmte Antworten auf bestimmte Fragen gesucht werden, wobei Fragestellungen, die in einer besonderen Situation noch sinnvoll erschienen, im Mittelpunkt der Auseinandersetzungen standen [...], in einer späteren Problematik an die Peripherie des intellektuellen Geschehens gedrängt werden [...]“ Ebd.
} 


\section{Reflexion über die Postmoderne - eine Dauerbaustelle}

Möchte man sich einen Überblick über das Phänomen der Postmoderne verschaffen, so bekommt man zuerst den Eindruck, dass sehr viele dieser Problematik gewidmete Arbeiten sich mit Aufzählungen von Merkmalen begnügen, mit denen dann eine Epoche nach dem Niedergang der Moderne und ihre kulturellen Erzeugnisse etikettiert werden. Oft ist dabei nicht auf den ersten Blick zu erkennen, in welchem gesellschaftlich-kulturellen Bereich diese unbekümmerte Etikettierung tobt, es wird nicht klar, wie z.B. die postmoderne Literatur mit der postmodernen Philosophie oder der postmodernen Weltanschauung einer postindustriellen Gesellschaft in Verbindung gebracht werden sollte, es wird endlich schweigsam angenommen, die Postmoderne markiere eine Wende (oder eine Reihe von Wenden) von globaler Tragweite. Eine solide und einleuchtende Annäherung an ein historisches Phänomen, das so gerne mit dem epochalen Wandel gleichgesetzt wird, bedarf jedoch meines Erachtens in erster Linie einer präzisen Erkundung und Sondierung des Zeitgeistes, d.h. der geistigintellektuellen Kondition der Gesellschaften, bei denen das Aufkommen des Neuen wahrgenommen wurde. Ein Hauptcharakteristikum der Zeit nach der Moderne ${ }^{15}$, das zugleich eine Diagnose zur Entwicklung der abendländischen Gesellschaft liefert, formulierte präzise Ende der 80er Jahre Wolfgang Welsch: „Die Postmoderne ist diejenige geschichtliche Phase, in der radikale Pluralität als Grundverfassung der Gesellschaften real und anerkannt wird und in der daher plurale Sinn- und Aktionsmuster vordringlich, ja dominant und obligat werden.“ ${ }^{16}$ Bevor die Bedeutung und die Konsequenzen einer radikalen Pluralität für die Geisteswissenschaften reflektiert werden, möchte ich zunächst das Verhältnis des Postmodernen zum Modernen erhellen. Grob gesagt kann die Postmoderne entweder als Nachmoderne oder als Anti-Moderne konzipiert werden. Der erste Fall würde bedeuten, dass wir es mit einer Erschöpfung der Moderne zu tun haben und dass diese durch eine neue

\footnotetext{
${ }^{15}$ Um die begriffliche Verwirrung zu vermeiden, bleibe ich konsequent beim Gebrauch der Bezeichnung, die Moderne'. Ich verzichte dabei z.B. auf die Verwendung von Konkretisierungen der Moderne, wie ,Spätmoderne' oder ,Modernismus'. Da es verschiedene Modernen gab (was ich auch in diesem Kapitel erwähne), konzentriere ich mich meistens auf die (literarischen) Merkmale der Moderne (vor allem ihrer letzten Phase im 20. Jahrhundert), von denen sich die Postmoderne abzusetzen suchte bzw. die stark modifizierte. Die Postmoderne bezeichne ich auch als die ,Nachmoderne'.

${ }^{16}$ Wolfgang Welsch, Unsere postmoderne Moderne, Weinheim 1987, S. 5. Welsch unterscheidet zwischen der Postmoderne, die er als „Verfassung radikaler Pluralität“ versteht und dem „Postmodernismus als deren Konzeption“. Ebd., S.5. Natürlich stammt diese Diagnose nicht von Welsch, sie wurde Ende der 70er Jahre von dem französischen Philosophen Jean-François Lyotard gestellt. Dem französischen Denker sowie Jürgen Habermas als den wichtigsten Theoretikern der Postmoderne widme ich ein separates Unterkapitel. (Siehe: S. 23-28.)
} 
Formation ersetzt wurde, im zweiten Fall würde die Moderne einen Teil ihrer Kraft noch behalten, sie hätte jedoch inzwischen aus sich selbst ihren Gegner hervorgebracht. ${ }^{17}$ Anders als Baran, der diese Alternative für eine stets präsente hält, betont Welsch den Fehler, die Postmoderne für eine Trans- oder Anti-Moderne halten zu wollen: ,[...] ist die Postmoderne im Gehalt keineswegs anti-modern und in der Form nicht einfach trans-modern, sondern ist als die exoterische Einlösungsform der einst esoterischen Moderne des 20. Jahrhunderts zu begreifen. Wofür man auch sagen kann: Sie ist eigentlich radikal-modern $[\ldots]^{\text {“18 }}$ Als strikt post-modern darf nach Welsch die Postmoderne gedacht werden, wenn wir die Moderne mit der Neuzeit gleichsetzen, denn „Postmoderne verabschiedet deren Grundobsession: die Einheitsträume, die vom Konzept der Mathesis universalis über die Projekte der Weltgeschichtsphilosophien bis zu den Globalentwürfen der Sozialutopien reichten. ${ }^{\text {"19 }}$ Bei einem genaueren Betrachten zeigt sich jedoch, dass die Postmoderne wesentlich mehr als nur Einheitsträume der Neuzeit zu verabschieden suchte. Um herauszufinden, inwieweit sich die Postmoderne von der Moderne absetzen wollte, brauchen wir eine möglichst scharfe Konturierung der Letzten, mit ihren Paradigmen, Zielen und historisch klar lokalisierbaren Höhepunkten.

Generell situieren die Franzosen die Anfänge der Moderne in der Zeit Nietzsches und Mallarmés ${ }^{20}$ und denken sie als „ein ästhetisches Phänomen, dessen Energien und Impulse sich der bewußt vorangetriebenen Zersetzung herkömmlicher Denk-, Schreib- und Repräsentationsweisen verdanken.“21 Jürgen Habermas dagegen, der prominenteste deutsche Theoretiker der (Post)Moderne, assoziierte die Moderne mit den Traditionen der Aufklärung, die er im Allgemeinen positiv bewertete und für deren Fortsetzung er plädierte. ${ }^{22}$ Die französischen Denker scheinen den Diskurs der Aufklärung allzu einseitig ,mit einer Geschichte von Terror und Einkerkerung [...], die von den Jakobinern über die ,metarecits“

\footnotetext{
${ }^{17}$ Vgl. Bogdan Baran, Postnietzsche, Kraków 2003, S. 177.

${ }^{18}$ Wolfgang Welsch, a.a.O., S. 6.

19 Ebd.

${ }^{20}$ Vgl. Andreas Huyssen, Postmoderne - eine amerikanische Internationale, in: Andreas Huyssen, Klaus Scherpe (Hg.), Postmoderne. Zeichen eines kulturellen Wandels, Reinbek bei Hamburg 1986, S. 27. Es ist also die Zeit, die die literarische Kritik als Modernismus bezeichnet.

${ }^{21}$ Ebd.

${ }^{22}$ Vgl. ebd. Diese optimistische Sicht und der Versuch Momente der Aufklärung in den philosophischen Diskurs wiedereinzubeziehen, sind, was Huyssen betont, auch für Deutschland keine Selbstverständlichkeit. Die Vorgänger Habermas' aus der Frankfurter Schule waren in puncto die Fortsetzung der Aufklärung wesentlich pessimistischer. Diese optimistische Positionierung Habermas' und seine moderaten Konsenswünsche inspirierten das Zustandekommen der interessantesten und fruchtbarsten Diskussion um die Postmoderne, deren Opponent Jean-François Lyotard zu dem prominentesten Diagnostiker der postmodernen Zeit wurde.
} 
der Meisterdenker Hegel und Marx ins sowjetische Gulag führt‘ ${ }^{\star 23}$, zu identifizieren, was für das Habermassche Projekt der Vollendung der Moderne nicht akzeptabel sein konnte. Der zweite wichtige Punkt seiner Kritik an französischer Diagnose betraf die Vision der Postmoderne im Geist Nietzsches. Habermas lehnte sie als anti-modern (anti-aufklärerisch) $\mathrm{ab}$, er warf ihr eine allzu enge Fassung der Moderne vor, besonders im Bereich der Ästhetikreflexion. ${ }^{24}$

Die Bewertung der Verwirklichung der Aufklärungsideen in ihrer französischen und deutschen Version zeigt sofort, wie unterschiedlich die Erwartungen gegenüber der Nachmoderne sein müssten. Die Ersten verkündeten mit der Postmoderne die Ära der radikalen Pluralität und somit den endgültigen Bruch mit den modernen Versuchen der Rettung der Einheit, selbst im Bereich der Subjektivität. Die Letzten dagegen fanden es einfach zu schade oder schlicht unmöglich, sich vom Klima und den Früchten der Moderne in toto $\mathrm{zu}$ verabschieden. Um $\mathrm{zu}$ verstehen, gegen welche moderne Qualitäten sich die Postmoderne $\mathrm{zu}$ profilieren suchte, müssen wir uns darüber im Klaren sein, welche Konzeption der Moderne wir der Postmoderne entgegenstellen.

Hans Robert Jauß lokalisiert die Anfänge des modernen Denkens bereits in der Mitte des 18. Jahrhunderts bei der Rousseauschen Kulturkritik. Das Ende der Moderne markierten 200 Jahre später die Ideen Adornos aus seiner Dialektik der Aufklärung. ${ }^{25}$ In dieser Zeit lassen sich nach Jauß drei Schnittstellen bestimmen, die jeweils den Charakter der Moderne sowie das Verständnis des Adjektivs modern modifizierten. Die erste Phase begann etwa 1800 an der Schwelle zur Romantik mit der ästhetischen Revolution, die

„im Zeichen des sich durchsetzenden Historismus die Antike als klassisches Altertum in die Zeitenferne einer anderen Vergangenheit entrückte, die Moderne mit der neuen Ästhetik des Erhabenen, Interessanten und Sentimentalischen aus dem Bannkreis des klassisch Schönen hinauswies und ihr das Ziel einer ästhetischen Bildung setzte [...] $]^{\text {(26 }}$

Die Wende zum Neuen markierte um die Mitte des 19. Jahrhunderts die Theorie der Vergänglichkeit des Schönen Baudelaires, sein Verständnis des Ästhetizismus als der

\footnotetext{
${ }^{23}$ Ebd., S. 28.

${ }^{24}$ Vgl. ebd. Zu Recht, wie ich meine, findet Huyssen nach Habermas die französische Einschätzung des Erbes der Aufklärung als zu eng und sogar politisch gefährlich: „Auschwitz war schließlich trotz der totalen Rationalisierung der Maschinerie des Todes keine Folge eines Zuviels an aufgeklärter Vernunft, sondern im Gegenteil Resultat eines rabiaten Antiaufklärungs- und Antimodernitätsaffekts."

${ }^{25}$ Vgl. Hans Robert Jauß, Der literarische Prozeß des Modernismus von Rousseau bis Adorno, in: Studien zum Epochenwandel der ästhetischen Moderne, Frankfurt am Main 1989, S. 74.

${ }^{26}$ Ebd., S. 76.
} 
Kehrseite des Industrialismus ${ }^{627}$ und „Flauberts Poetik der fragmentierten Wahrnehmung.“،28 Die letzte Phase der Moderne eröffnete 1912 die Geburt der Avantgarde, die in den Künsten mit der Erhaltung der Distanz zum Kunstwerk und dessen Kontemplation brach und stattdessen eine aktive Teilnahme des Kunstempfängers im Sinne der Ästhetisierung der Lebenspraxis forderte. ${ }^{29}$ Die Zugehörigkeit der Avantgarden zur Moderne ist nicht eindeutig. Baran schlägt vor, diese als querliegende in der Nachfolge Moderne - Postmoderne zu betrachten und bezeichnet sie als Moderne in Anführungszeichen. Die äußeren Ähnlichkeiten mancher Avantgarden (bzw. Neo- oder Postavantgarden) werden nicht selten bei der Postmoderne gefunden. ${ }^{30}$

Die drei Modernen Jauß bieten eine erste mögliche theoretische Basis für die Überlegungen zu den Geburtsbedingungen des Postmodernen. Auch Baran unterscheidet drei Modernen, wobei er zugleich die Schärfe ihrer Konturierung und die Umstände für die Herausbildung gegensätzlicher Positionen reflektiert. Am stärksten wirkte der angelsächsische Modernismus der 20er Jahre des vergangenen Jahrhunderts ein, dessen Fortdauer sich bis in die 60er Jahre aufrechterhalten konnte. Das zweite Jahrzehnt des 20. Jahrhunderts gilt sowohl in der Poesie als auch in der Prosa als Höhepunkt der Moderne. ${ }^{31}$ Diese am deutlichsten profilierte der Modernen, ,konzentriert auf die Idee der Autonomie des Werkes, seines inneren Sinns, auf die Idee des demiurgischen, mit seinem Schaffen beschäftigten Autors, das er auto(r)thematisch in seinem Werk überlegt" ${ }^{32}$, inspirierte und provozierte zugleich am stärksten diejenigen Künstler, die allmählich diese allzu ernste und elitäre Profilierung zu verabschieden suchten. $\mathrm{Zu}$ den ambitionierten und erfolgreich erreichten Zielen der modernen Schriftsteller gehörten vor allem die Versuche „to break the hold over their audience's minds of conventionalized, nineteenth-century modes of perception [und] compel their audience to

\footnotetext{
${ }^{27}$ Vgl. Ryszard Nycz (Red.), Odkrywanie modernizmu [Das Entdecken des Modernismus'], Kraków 1998, S. 8.

${ }^{28}$ Hans Robert Jauß, a.a.O., S. 76.

${ }^{29} \mathrm{Vgl}$. Ryszard Nycz, a.a.O., S. 8.

${ }^{30}$ Vgl. Bogdan Baran, Postnietzsche, S. 173f. Baran betont die Heterogenität der Avantgarden und ihre - andere als bei der Postmoderne - Herkunft.

${ }^{31}$ Ebd., S. 172f. und Bogdan Baran, Postmodernizm i końce wieku [Der Postmodernismus und die Enden des Jahrhunderts], Kraków 2003, S. 34. Die weniger scharf profilierte Moderne lokalisiert Baran gegen das Ende des 19. Jahrhunderts und verbindet sie mit der antipositivistischen Wende. Die dritte Moderne - die philosophische startete bereits mit Descartes' neuzeitlicher Idee der Subjektivismus und bildete die neue Dimension des neuzeitlichen Bewusstseins. Die Philosophie Descartes' bedeutete eine permanente Dominanz der Ratio und als solche wurde sie von Nietzsche in den letzten Jahrzehnten des 19. Jahrhunderts einer heftigen Kritik unterzogen. Nietzsches Vernunftkritik ist für Habermas ein Wendepunkt in der Geschichte der Moderne. Vgl. Bogdan Baran, Postnietzsche, S.173 und Bogdan Baran, Postmodernizm i końce wieku [Der Postmodernismus und die Enden des Jahrhunderts], S. 91ff.

${ }^{32}$ Bogdan Baran, Postnietzsche, S. 173 [„skupiony wokół idei autonomii dzieła, jego wewnętrznego sensu, wokół idei demiurgicznego autora zajętego własną stwórczościa, którą auto(r)tematycznie rozważa w samym dziele."]
} 
confront an alternative, meta-world" whose nature transcends the conventional reality principle. ${ }^{, 33}$ In erster Linie experimentierte die moderne Literatur in ihrer letzten Phase mit der Störung der Linearität der Erzählung, mit dem Einsatz der unglaubwürdigen und nicht mehr allwissenden Erzähler und mit der Lockerung und/oder der Verwischung der Beziehungen zwischen dem Autor, dem Erzähler und den Protagonisten, um den Leser dazu herauszufordern, seine epistemologischen Strategien zu revidieren, seinen Glauben an die stabile Wirklichkeit zu unterlaufen und die Rolle und Grenzen der subjektiven Wahrnehmung angesichts wachsender Verfremdung der Welt $\mathrm{zu}$ hinterfragen. ${ }^{34}$ Eine der wichtigsten Tendenzen, die die literarische Moderne in ihren letzten Jahrzehnten zunehmend prägte, war der graduelle „Rückzug des Individuums aus einer als feindlich betrachteten Welt in den Bereich persönlicher Wertbegriffe und Verhaltensmuster [..]“ 35 Angesichts der Wahrnehmung des Welthaftigkeitsverlustes entfaltete diese Literatur eine bisher nicht bekannte Subjektorientierung, die die intensiven Versuche der Darstellung der Bewusstseinsarbeit ins Zentrum des schriftstellerischen Interesses rückte. ${ }^{36}$

Die Strategien, die die postmodern attackers ${ }^{37}$ anwenden, um den modernen Geist effektiv $\mathrm{zu}$ subvertieren, sind zweierlei. Wenn wir wie Welsch die Postmoderne als radikalisierte Moderne begreifen, dann werden die modernen Momente und Werte sozusagen auf ihre Resistenz getestet, indem sie vervielfältigt und/oder verzerrt werden. Diese quantitativ angelegte Subversion braucht keine originellen Qualitäten, um mit diesen mit der Moderne zu konkurrieren. So gesehen hat Maria Anna Potocka Recht, wenn sie behauptet, „die Moderne verliert nicht gegen eine bessere Idee, sondern sie erliegt einer inneren Abwertung. [...] Dadurch, dass sich die Moderne aus inneren Gründen zurückzieht, tritt die Postmoderne ohne Kampf ein, und sie muss keine Ideologie sein. Die Postmoderne kämpft gegen nichts.“338

\footnotetext{
${ }^{33}$ Richard Sheppard, The Problematics of European Modernism in: Steve Giles (editor), Theorizing Modernism. Essays in critical theory, London and New York 1993, S. 18.

${ }^{34} \mathrm{Vgl}$. ebd.

${ }^{35}$ Gerhard Hoffmann/Alfred Hornung/Rüdiger Kunow, "Modern", „Postmodern" und "Contemporary": Zur Klassifizierung der amerikanischen Erzählliteratur des 20. Jahrhunderts, In: Gerhard Hoffmann (Hg.), Der zeitgenössische amerikanische Roman: von der Moderne zur Postmoderne, B.1, Wilhelm Fink Verlag, München 1988, S.9.

${ }^{36}$ Vgl. Alfred Hornung/Rüdiger Kunow, Der amerikanische Gegenwartsroman und seine kulturelle Matrix, in: Gerhard Hoffmann (Hg.), a.a.O., S. 63 „die Bewusstseinsdarstellung wird nun - eigentlich zum ersten Mal - zum dominanten Faktor der narrativen Tiefenstruktur. " Gerhard Hoffmann, Das narrative System der Postmoderne und die Auflösung des Charakters im Erzähltext: Die Reduktionsformen von Handeln und Bewußtsein, In: Gerhard Hoffmann (Hg.), a.a.O., S. 183.

${ }^{37}$ So bezeichnete die postmodernen Schriftsteller Harry Levin, ein eingeschworener Anhänger der Moderne. Er beschuldigte die Postmodernisten, „über alles zu reden, nur nicht über den „mind“ des Menschen.“ Vgl. Gerhard Hoffmann/Alfred Hornung/Rüdiger Kunow, a.a.O., S. 15.

${ }^{38}$ Maria Anna Potocka, Manieryzm po modernizmie [Manierismus nach der Moderne] In: Postmodernizm. Teksty polskich autorów [Die Postmoderne. Die Texte polnischer Autoren], Kraków 2003, S. 139. („Modernizm
} 
Diese friedliche Umgestaltung des Modernen geschieht nach Potocka in der Einstellung der Geringschätzung und des Nachäffens, dank derer die Postmoderne einige der alten Bedeutungen zwar behält, sie entzieht jedoch der Moderne dabei „den bisherigen Komfort des Diktierens der Haltung. ${ }^{\text {“39 }}$ Es sei daher nicht verfehlt - schlussfolgert Potocka -, die Zeit des allmählichen Abschieds von der Moderne als ihren ,Manierismus“ zu bezeichnen. Wahrscheinlich hat doch die Moderne in ihrer letzten Phase den Zustand der Übersättigung und des Überreif-Seins erreicht. Leider sagt uns die Literaturwissenschaftlerin nichts darüber, in welchem Jahrzehnt sie die ,manieristischen“ Züge der (noch) herrschenden Epoche situieren würde. Eine kreative Destruktion der alten Ziele bei gleichzeitiger Abwesenheit neuer Ideen seien ihrer Meinung nach die Hauptmerkmale des modernen ,Manierismus', der von der schöpferischen Ahnung lebe, auf dem richtigen Weg zur Hervorbringung des Neuen zu sein. ${ }^{40}$

Die Vision einer kampflosen Konfrontation zweier Epochen mündet jedoch in eine Aporie, aus der wir meines Erachtens kaum einen plausiblen Ausweg finden. Eine Wende durch Radikalisierung ähnelt einem Experiment der Anreicherung, der Sättigung, der Verzerrung und zwar mit dem Ziel, die Erkenntnis darüber zu gewinnen, wann diese Versuche eine neue Qualität hervorbringen. So muss es z.B. Linda Hutcheon sehen, die als die wichtigsten Merkmale des postmodernen Schreibens unter anderem Introversivität (als die radikale Form der Autoreflexivität), das ironische Parodieren und die permanente ,Aufhebung der Richtigkeit‘ nennt. ${ }^{41}$ Das Problem dieser Zuschreibungen beruht meiner Meinung nach auf ihrer extremen Subjektivität. Wann ist die Autoreflexivität radikal genug, um als ,introvers' wahrgenommen zu werden, wann beginnt das Parodieren zusätzlich ironisch zu wirken und wann ist die ,Aufhebung der Richtigkeit‘ als permanent zu bezeichnen? Diese Kategorien scheinen schwierig intersubjektiv vermittelbar zu sein.

Ein vorsichtigeres und somit literaturwissenschaftlich effektiveres Verfahren hat Peter Zima verfolgt. Seine Hauptannahme, dass ,der Unterschied zwischen Spätmoderne (Modernismus) und Postmoderne nicht so sehr im Auftreten neuer stilistischer Merkmale und Begriffe besteht, sondern im Funktionswandel schon bekannter Erscheinungen u.a. im

nie przegrywa z lepszą ideą, tylko ulega wewnętrznej dewaluacji. [...] Dzięki temu, że modernizm wycofuje się z przyczyn wewnętrznych, postmodernizm wchodzi bez walki i nie musi być ideologią. Postmodernizm z niczym nie walczy.")

${ }^{39}$ Ebd., S. 139. („dotychczasowy komfort dyktowania postaw“)

${ }^{40}$ Vgl. ebd., S. 145.

${ }^{41}$ Vgl. Linda Hutcheon, A Poetics of Postmodernism. History, Theory, Fiction, New York and London 1988,

S. 124-140 und Anna Burzyńska, Postmoderna: pomiędzy Wieżq Babel a Bibliotekq Babel [Zwischen dem Babelturm und der Babelbibliothek] In: Postmodernizm. Teksty polskich autorów [Die Postmoderne. Die Texte polnischer Autoren], Kraków 2003, S. $69 f$. 
Hinblick auf das Problem der individuellen Subjektivität“" ${ }^{42}$, plausibilisiert seine Charakteristika der beiden Perioden. Eine z.B. von ihm detailliert analysierte Frage der Intertextualität wird also nicht unter dem Aspekt ihrer Radikalisierung untersucht, sondern vergleicht die Unterschiedlichkeit der Funktionen, die die Umsetzung dieser (Text)Strategie erfüllen sollte. ${ }^{43}$ Solch ein Vorgehen ermöglichte Zima das Hervorheben der Spitzfindigkeiten, die die Komplexität der Intertextualität entfalten lässt: „In der Postmoderne verdrängt das intertextuelle $S$ p i e 1 [Hervorhebung - K.S.] mit historischen und zeitgenössischen Sprachformen die intertextuelle $\mathrm{S} \mathrm{u} \mathrm{c} \mathrm{h} \mathrm{e} \mathrm{[Hervorhebung} \mathrm{-} \mathrm{K.S.]} \mathrm{der}$ Moderne: die Suche nach Wahrheit, Wertsetzung, Subjektivität und Identität sowie das Streben nach Utopie.“ ${ }^{44}$ Das Sondieren des möglichen Funktionswandels bestimmter Merkmale in Abwesenheit des Paradigmenwechsels scheint für die literaturwissenschaftlichen Untersuchungen einleuchtender zu sein als die Versuche der Messung der Radikalität, deren die modernen Erzähltechniken unterzogen wurden.

Die zweite Strategie der postmodernen Subversion beruht auf dem Herauspräparieren einer originellen Idee. Nicht viele Theoretiker der Postmoderne (insbesondere Literaturwissenschaftler) haben dieses Unterfangen mit Erfolg gekrönt, d.h. Merkmale oder Verfahren entdeckt, die die Analyse der nachmodernen literarischen Texte fruchtbarer machen würde. Einer der einflussreichsten Forscher der postmodernen Literatur - Brian McHale - versuchte es mit einer ganz groben Fragestellung, d.h. mit der Frage: „How postmodernist poetics as a whole stands in opposition to modernist poetics as a whole. “45 Solche Formulierung des Dilemmas resultierte aus der Enttäuschung, die er erfuhr, indem er sich einige Kataloge postmoderner Merkmale angeschaut hat, die als Oppositionen zu den Eigenschaften moderner Poetik entstanden. In allen von McHale untersuchten Beispielen schienen die kreierten Oppositionen allzu heterogen und nicht integriert zu sein. ${ }^{46}$ Die Lösung des Problems fand er endlich in der Konzeption der Dominante und zwar mit folgender Annahme: „With the help of this conceptual tool, we can both elicit the systems underlying these heterogeneous catalogues, and begin to account for historical change. For to describe change of dominant is

\footnotetext{
${ }^{42}$ Peter Zima, Das literarische Subjekt: Zwischen Spätmoderne und Postmoderne, Tübingen und Basel 2001, S. IX.

${ }^{43}$ Vgl. Ebd., S. IX. „Während Ironie und Intertextualität im Modernismus noch die Funktion erfüllten, eine kritische und selbstkritische Subjektivität zu begründen, leiten sie in der Postmoderne die Auflösung der Subjektivität im Textexperiment ein."

${ }^{44}$ Ebd., S. 195.

${ }^{45}$ Brian Mc Hale, Postmodernist Fiction, London and New York 1987, S. 7.

${ }^{46}$ Vgl. ebd., S. 7. „these are static oppositions, telling us little or nothing about the mechanisms of historical change."
} 
in effect to describe the process of literary-historical change." ${ }^{47}$ Bei einer genauen Untersuchung von Beispielen literarischer Prosa, die als modern oder postmodern etikettiert wurden, konnte McHale feststellen, dass der moderne Roman durch die epistemologische, der postmoderne dagegen durch die ontologische Dominante charakterisiert sei. Es heißt, dass sich die moderne Literatur mit Fragen beschäftige wie: „How can I interpret this world of which I am a part? And what am I in it?” Die postmodernen Texte fragen aber danach: „Which world is this? What is to be done in it? Which of my selves is to do it?"48 Interessant in dieser Konzeption ist die zusätzliche Behauptung, dass die ontologische Dominante als Resultat der Steigerung der epistemologischen Dominante zustande komme und umgekehrt. ${ }^{49}$ Es gibt bestimmt auch genug Beispiele von Prosa, in der sich beide Typen von Fragen finden lassen. Die Entdeckung McHales eröffnet meines Erachtens eine sehr nützliche Perspektive, aus der ein Teil der literaturwissenschaftlichen Analyse betrieben werden kann, und sie sensibilisiert auch für die Untersuchung von Texten, die sich an der Schnittstelle zwischen Moderne und Postmoderne situieren.

Die bisherige Diskussion über die Postmoderne lässt sich nur schwer als geordnet zusammenfassen. Einerseits hat sie, wie es Ryszard Nycz behauptet, „die Phase der Kristallisierung des Basisrepertoires der Standpunkte ${ }^{\text {“50 }}$ hinter sich, die eher kontinuierlich intensiv exploriert als durch eine radikale Kritik oder originelle Ideen verdrängt werden. Der Beweis dafür ist für Nycz die Sammlung von Konzepten, die zu einer Art Kanon der Reflexion über die Postmoderne und zugleich zu der Pflichtlektüre für all diejenigen wurde,

\footnotetext{
${ }^{47}$ Ebd. McHale beruft sich auf die Konzeption der Dominante Roman Jakobsons: „In der Evolution der poetischen Form geht es nicht so sehr um das Verschwinden gewisser Elemente und das Auftauchen anderer, sondern um eine Verschiebung in der Wechselbeziehung zwischen den diversen Komponenten des Systems, also um eine Verschiebung der Dominante. Innerhalb eines gegebenen Komplexes poetischer Normen im allgemeinen, oder vor allem innerhalb der Klasse poetischer Normen, die für eine gegebene dichterische Gattung gelten, werden Elemente, die ursprünglich sekundär waren, wesentlich und primär. Andererseits werden die Elemente, die ursprünglich die Dominante bildeten, nebensächlich und fakultativ." Roman Jakobson, Poetik. Ausgewählte Aufsätze 1921-1971, Frankfurt am Main 1979, S. $215 f$.

${ }^{48}$ Ebd., S. 9f. Weitere Fragen der Modernen waren: „What is there to be known? Who knows it? How do they know it, and with what degree of certainty? How is knowledge transmitted from one knower to another, and with what degree of reliability? How does the object of knowledge change as it passes from knower to knower? What are the limits of the knowable?" [...] Other typical postmodernist questions bear either on the ontology of the literary text itself or on the ontology of the world which is projects, for instance: What is a world? What kinds of worlds are there, how are they constituted, and how do they differ? What happens when different kinds of worlds are placed in confrontation, or when boundaries between worlds are violated? What is the mode of existence of a text, and what is the mode of existence of the world (or worlds) it projects? How is a projected world structured?"

${ }^{49}$ Vgl. ebd., S. 11. „[...] push the epistemological questions far enough and they 'tip over' into ontological questions. By the same token, push ontological questions far enough and they tip over into epistemological questions [...]"

${ }^{50}$ Ryszard Nycz, Postmodernizm. Antologia przekładów [Die Postmoderne. Die Antologie der Textübersetzungen], Kraków 1996, S. 8. („faze krystalizacji podstawowego repertuaru stanowisk”]
} 
die - aus welchen Gründen auch immer - das Phänomen Postmoderne verstehen wollen. ${ }^{51}$ Andererseits macht eben diese ungeordnete Explorationsarbeit an den bisher formulierten Thesen zur Postmoderne diesen geisteswissenschaftlichen ,Diskurs“ zu einer Dauerbaustelle, die ihn in viele Minidiskurse aufsplittert und jede Hoffnung auf die Vereinheitlichung der Einsichten zunichtemacht. Sich über diese Lage zu beschweren würde jedoch bedeuten, den Geist der Postmoderne nicht wirklich wahrgenommen und ihre manifesten Postulate missverstanden zu haben. Das Chaos der friedlich koexistierenden ,Paralogien“ (fröhlich diagnostiziert und verkündet als Kern des heutigen Entwicklungstandes der abendländischen Gesellschaften) wurde dank Jean-François Lyotard zur populärsten Vorstellung der postmodernen Zeit. Diese radikale Pluralität, mit der fast jeder kulturwissenschaftlicher Bereich gesättigt wird, birgt jedoch in sich diskursive Fallen ${ }^{52}$, wenn man bedenkt, dass die Postmoderne auch (oder vor allem) die Ära der permanenten Ästhetisierung ist. Die Gefahren lauern meines Erachtens vor allem in dem Phänomen der Ästhetisierung der Theorien. Bei vielen Konzepten, die die Spezifik der postmodernen Wirklichkeit zu beschreiben suchen, hat man den Eindruck, dass sie in erster Linie auf ihre ästhetische Wirkung bedacht sind, statt ihre Explikationskraft gründlich zu überdenken. Die stark ästhetisierten Ideen vermindern dabei die Möglichkeit ihrer intersubjektiven Vermittlung bzw. Kritik, da sie sich oft an der Schnittstelle zu den Geschmacksurteilen situieren, und über Geschmäcker wird bekanntlich nicht diskutiert. Die (Quelle der) Wende zum Ästhetischen, das in der Postmoderne bereits an seine Grenzen gelangt, ist nicht einfach (präzis) zu lokalisieren. Viele Spuren führen jedoch zu einem Denker, der am gravierendsten die postmodernen Philosophen inspirierte, nämlich zu Friedrich Nietzsche.

\footnotetext{
${ }^{51}$ Vgl. ebd.

52 Ich beschäftige mich mit diesem Problem genauer in dem Unterkapitel Postmoderne - das Zeitalter der permanenten Ästhetisierung. (Siehe: S. 29-35.)
} 


\subsection{Friedrich Nietzsche - der Vorläufer par excellence der Postmoderne}

Mit Nietzsche startet eine Kritik der modernen Vernunft, die bisher in der Radikalität und der Vehemenz ihresgleichen suchte: „Die subjektzentrierte Vernunft wird mit dem schlechthin Anderen der Vernunft konfrontiert." ${ }^{, 53}$ Dieses Andere, das der sich auf dem Weg zur Emanzipation befindenden Vernunft entgegengestellt wurde, findet Nietzsche in der dionysischen Kunst, deren Wahrheit wahrer als die angebliche Wahrheit der emanzipierten Vernunft sei. ${ }^{54}$ Den Kult des Dionysos versteht Nietzsche in seiner ganzen Radikalität, den griechischen Halbgott preist er als den, „der radikal vom Fluch der Identität erlöst, der das Prinzip der Individuierung außer Kraft setzt, das Polymorphe gegen die Einheit des transzendenten Gottes, die Anomie gegen die Satzung zur Geltung bringt. ${ }^{\text {(55 }}$ Diese zutiefst ästhetische Erfahrung zielt auf die „Steigerung des Subjektiven bis zur völligen Selbstvergessenheit" ${ }^{, 56}$, sie führt jedoch durch

„das ungeheure Grausen [...], welches den Menschen ergreift, wenn er plötzlich an den Erkenntnissformen der Erscheinung irre wird, indem der Satz vom Grunde, in irgend einer seiner Gestaltungen, eine Ausnahme zu erleiden scheint. Wenn wir zu diesem Grausen die wonnevolle Verzückung hinzunehmen, die bei demselben Zerbrechen des principii individuationis aus dem innersten Grunde des Menschen, ja der Natur emporsteigt, so thun wir einen Blick in das Wesen des Dionysischen, das uns am nächsten noch durch die Analogie des Rausches gebracht wird." ${ }^{57}$

Im dionysischen Mysterium entdeckte Nietzsche eine neuartige Wahrnehmung - das ästhetische Phänomen, das das Subjekt in dem Augenblick aufzulösen vermochte:

„[...] erst wenn die Kategorien des verständigen Tuns und Denkens eingestürzt, die Normen des täglichen Lebens zerbrochen, die Illusionen der eingeübten Normalität zerfallen sind - erst dann öffnet sich die Welt des Unvorhergesehenen und schlechthin Überraschenden, der Bereich des ästhetischen Scheins, der weder verhüllt noch offenbart, weder Erscheinung noch Wesen ist, sondern nichts als Oberfläche." 58

\footnotetext{
53 Jürgen Habermas, Der philosophische Diskurs der Moderne, Frankfurt am Main 1985, S. 117.

${ }^{54} \mathrm{Vgl}$. Bogdan Baran, Postmodernizm i końce wieku [Der Postmodernismus und die Enden des Jahrhunderts], Kraków 2003, S. 91.

55 Jürgen Habermas, a.a.O., S. 115.

${ }^{56}$ Ebd., S. 116.

${ }^{57}$ Friedrich Nietzsche, Die Geburt der Tragödie, München 1999, S. 28.

58 Jürgen Habermas, a.a.O., S. 116.
} 
Das Dionysische wird in seiner radikalen Form von der Ekstase begleitet, im Rausch verliert der Erlebende das Bewusstsein des Rausches, wodurch sich sein Erlebnis jeder diskursiven Erkenntnis entzieht. ${ }^{59}$ Das Verlockendste am Dionysischen ist

„eine dreifache Entgrenzung, eine dreifache Überwindung des principium individuationis. Der Mensch entgrenzt sich zur Natur hin, er fühlt sich eins mit ihr. Er entgrenzt sich zu Mitmenschen hin im Orgiasmus, in der Liebe und im Rausch der Masse und die dritte Schranke wird im Inneren des Individuums niedergelegt. Das Bewusstsein öffnet sich für sein Unbewusstes. “60

Das ästhetische Phänomen war hier breiter verstanden als nur im Kontext der Wahrnehmung des Kunstwerks, denn „die Kunst darf als die eigentlich metaphysische Tätigkeit des Menschen gelten, weil das Leben selbst auf Schein, Täuschung, Optik, Notwendigkeit des Perspektivischen und des Irrtums beruht." ${ }^{\text {61 }}$ Wenn sich die Welt, wie es Nietzsche wollte, nur als ästhetische rechtfertigen lasse, dann wäre der „Umgang mit der Welt als mit dem Gebiet der theoretischen Fiktionen“62, erst dann sinnvoll, wenn sie ästhetisch erlebt werden, „d.h. in der Art und Weise, die für die ästhetische Erfahrung charakteristisch ist. “63 Die Besonderheit des Entgrenzungs- erlebnisses beruht zusätzlich darauf, dass es sowohl von einer Lust als auch von einem Ekel begleitet sei. Die Lust resultiert aus der Auflösung des Bewusstseins, die zugleich die Grenzen des Daseins verschwinden lässt, der Ekel wird sofort dann verspürt, wenn der dionysische Rausch vorbei ist. ${ }^{64}$ Das nietzscheanische ästhetische Phänomen wurde jedoch in seiner Radikalität nicht erkannt und in die Postmoderne nur teilweise integriert. Baran macht darauf aufmerksam, dass zwar auch die Postmodernen der Ästhetik den Vorrang über die Metaphysik gegeben haben, die von ihnen propagierte ästhetische Erfahrung ist jedoch wesentlich kühler als die des dionysischen Sich-Verlierens. ${ }^{65} \mathrm{Zu}$ Unrecht also,

\footnotetext{
${ }^{59}$ Vgl. Rüdiger Safranski, Nietzsche Biographie seines Denkens, München 2000, S. 58. Im Gegensatz zum apollinischen Erlebnis, das stets reflexiv bleibt, verliert der Dionysiker die Möglichkeit, sich von außen beobachten zu können.

${ }^{60}$ Ebd., S. 59.

${ }^{61}$ Jürgen Habermas, a.a.O., S. 118. „Die Welt erscheint als ein Gewebe aus Verstellungen und Interpretationen, denen keine Absicht und kein Text zugrundeliegen. Die sinnschöpferische Potenz bildet zusammen mit einer Sensibilität, die sich auf möglichst vielfältige Weise affizieren lässt, den ästhetischen Kern des Willens zur Macht. Dieser ist zugleich ein Wille zum Schein, zur Vereinfachung, zur Maske, zur Oberfläche [...]"

${ }^{62}$ Bogdan Baran, Postnietzsche, S. 220. („obcowania ze światem jako dziedziną teoretycznych fikcji”)

${ }^{63}$ Ebd. (,to znaczy w sposób charakterystyczny dla doświadczenia estetycznego.")

${ }^{64}$ Vgl. Rüdiger Safranski, a.a.O., S. 73.

${ }^{65}$ Safranski schildert kurz eine Phase in Nietzsches Leben, in der er sich eine Ernüchterungskur verschrieb. Gemeint war der Gebrauch der nüchternen Wissenschaft, angesichts der Gefahr, von den rauschhaften Empfindungen der Künste, der Religion oder der Philosophie überwuchert zu werden. Es ist interessant, dass trotz des Vorwurfs, die Wissenschaft verflache das Leben, Nietzsche darüber grübelte, der Gesundheit zugute, zwei nebeneinander liegende Hirnkammer einzurichten: eine für die Kraftquelle, die andere für den Regulator.
} 
behauptet Baran, hat Habermas Nietzsche die Rolle des Patrons der angeblich dionysischen Postmoderne zugeschrieben, da ,die postmoderne Literatur und Kunst statt zu einem dionysischen Rausch, zu einem kühlen Spiel der Stile, zu der reinen Demonstration der Vielheit wurden.“ ${ }^{66}$ Das ,Cool-Sein“ der Postmodernen resultiert nach Baran aus der Tatsache, dass die Generation, die die Nachmoderne hervorgebracht habe, meistens nach dem Zweiten Weltkrieg aufgewachsen sei. Somit seien ihr die traumatischen Grenzerfahrungen erspart geblieben, die wiederum Nietzsche erlebt habe. Charakteristisch für diese postindustrielle Gesellschaft war, dass sie sowohl in der als auch gegen diese Gesellschaft leben wollte. ${ }^{67}$ In dieser Hinsicht bleibt für Baran unklar, „ob die Postmoderne durch die Nutzung der Pop-Kultur dies tatsächlich gegen die hohe Kunst tat oder, ob sie sich eher dadurch auf diese - ironische oder magische - Art und Weise von der Massenkultur distanzierte. “68

Indem wir Baran die Sondierung der Tiefen und der Intensität von Nietzsches Einflüssen auf die postmoderne Kultur verdanken, lokalisierte Zima weitere nachmoderne Bereiche und Tendenzen, die die Philosophie dieses Denkers radikal beeinflusste. Im Laufe seiner literaturwissenschaftlich-philosophischen Untersuchungen gewann Zima eine wichtige Erkenntnis, die er zu einer seiner Thesen in seinem Buch Das literarische Subjekt: Zwischen Spätmoderne und Postmoderne formulierte:

„Nietzsches Philosophie, die auf allen Ebenen mit dem begrifflichen Universalismus der rationalistischen Aufklärung und des totalisierenden Hegelianismus bricht, hat im Partikularisierungsprozeß, den die französische Philosophie der Nachkriegszeit durchgemacht hat, und der auch den Subjektbegriff erfaßt, wie ein starker Katalysator gewirkt. “69

\footnotetext{
„Mit Illusionen, Einseitigkeiten, Leidenschaften muss geheizt werden, mit Hilfe der erkennenden Wissenschaft muss den bösartigen und gefährlichen Folgen der Überhitzung vorgebeugt werden." Ebd., S. $203 f$.

${ }^{66}$ Bogdan Baran, Postnietzsche, S. 221 („postmoderna literatura i sztuka miast dionizyjskim rauszem staly sie chlodna gra stylow, czysta demonstracja wielosci.") Baran korrigiert auch die Annahme, Nietzsche sei der Vater des postmodernen Pluralismus gewesen. Die nietzscheanische Vielheit sei im Kontext des Kampfes gegen das moderne Ideal der Einheit situiert, es lasse sich dabei eine klare Tendenz zur Konzentration der Kraft erkennen, die auf den Sieg des Stärksten ziele. Die Postmoderne führe dagegen (ihrem Wesen nach) keinen Kampf gegen die Moderne, sondern plädiere für die Inkommensurabilität der Paradigmen. Vgl. Ebd., S. 122.

${ }^{67}$ Vgl. ebd., S. $229 f$.

${ }^{68}$ Ebd., S. 229f. („,czy postmodernizm wykorzystując popkulturę istotnie czynił to przeciw sztuce wysokiej, czy nie dystansował się raczej w ten - ironiczny lub magiczny - sposób do kultury masowej.") Baran stellt fest, dass die postmoderne Kultur lediglich das negativistische Potential Nietzsches Lehre aufgriff, die affirmative Seite seiner Ideen fand darin keinen Ausdruck.

${ }^{69}$ Peter Zima, Das literarische Subjekt: Zwischen Spätmoderne und Postmoderne, Tübingen und Basel 2001, S.226. Zima macht darauf aufmerksam, dass Nietzsches Einflüsse wesentlich stärker in Frankreich als in Deutschland waren und somit auch der nietzscheanische Partikularismus einen radikaleren Ausdruck bei den französischen als bei den deutschen Philosophen fand. Vgl. ebd., S. 227.
} 
Eine drastische Partikularisierung des Denkens war - wie uns Jean-François Lyotard in seiner berühmten Diagnose des ,postmodernen Wissens' unterrichtet - als Folge des zunehmenden Misstrauens gegenüber der Metaerzählungen der vergangenen Epoche zu verstehen. ${ }^{70}$ Lyotard, der außer der Stellung der Diagnose auch eine Alternative zu der von den modernen Ansprüchen herbeigeführten Krise zu liefern wusste, degradierte die wissenschaftlichen, ideologischen und philosophischen Formen der Erkenntnisgewinnung zu bloßen Sprachspielen, die sich in einer friedlichen Koexistenz entfalten durften. Mit dem Abschied von Metaerzählungen und dem Einsetzen des Partikularisierungsprozesses war das Scheitern des Universalismus` der Moderne endgültig besiegelt. ${ }^{71}$ Nietzsches Wende bedeutete jedoch weit mehr als das Zunichte-Machen der Einheitsbestrebungen der modernen Vernunft. Zima sieht in dem Autor von Die Geburt der Tragödie den ersten Philosophen, der den Körper zur Sprache brachte. ${ }^{72}$ Die Körperlichkeit als philosophisches Thema wurde gern von den postmodernen Intellektuellen aufgenommen und fand ihren prominentesten Ausdruck in den Schriften Michel Foucaults.

Die von Nietzsche initiierte Partikularisierungstendenz hatte aber noch eine weitere gravierende Konsequenz, die vor allem die postmoderne Philosophie und Literatur prägen sollte, nämlich diese, dass „das Subjekt als begrifflich-diskursive Instanz den nachmodernen Intellektuellen als ein schimärenhaftes Residuum abendländischer Metaphysik erscheint. Es wird unglaubwürdig, weil man es - analog zum Begriff - für eine Fiktion hält.“73 Die allmähliche Abwertung des Subjekts war in der Postmoderne durch mehrere Faktoren gefördert, von denen Zima vier als besonders prägend nennt: „1. d[ie] Säkularisierung der Gesellschaft; 2. d[ie] Unterwerfung fast aller sozialer Bereiche unter das Marktgesetz; 3. d[ie] ideologische und marktbedingte Zerstörung der Sprache; 4. de[r] arbeitsteilige Prozeß, der auch die Freizeit erfaßt.“74

Es besteht kein Zweifel daran, dass Nietzsche wie kein anderer Denker sowohl den Niedergang der Moderne als auch das Aufblühen der Nachmoderne beeinflusste. Dieser

\footnotetext{
${ }^{70}$ Es handelt sich um sein berühmt gewordenes Buch Das postmoderne Wissen. Mit seinen wichtigsten Thesen beschäftige ich mich im nächsten Unterkapitel.

${ }^{71}$ Vgl. Peter Zima, Das literarische Subjekt: Zwischen Spätmoderne und Postmoderne, Tübingen und Basel 2001, S. 225.

${ }^{72}$ Vgl. Ebd., S. 229. „und zwar so, daß nicht nur - wie etwa bei Hobbes - de corpore, also vom Körper die Rede war, sondern für den Körper, pro corpore plädiert wurde."

${ }^{73}$ Ebd., S. 233. „,Subjekt' ist die Fiktion, als ob viele gleiche Zustände an uns die Wirkung eines Substrats wären: aber wir haben erst die ,Gleichheit' dieser Zustände geschaffen [...]“" Friedrich Nietzsche, Aus dem Nachlaß der Achtziger Jahre, in: Ders., Werke Bd. VI, S. 627. (zit. nach Zima, a.a.O.)

${ }^{74}$ Ebd., S. 239.
} 
prophet of extremity ${ }^{75}$, wie ihn zutreffend Allan Megill bezeichnete, infizierte seine Epoche mit dem Virus der permanenten Skepsis, der im Prozess seiner Fortpflanzung den rational vereinheitlichenden Diskurs der Moderne auseinanderzumontieren vermochte, die Emanzipation der Vernunft stoppte und den Willen zur Macht auf die Oberfläche, zum bloßen Leben, zum Körper schickte. Trotz der von Baran erkannten Kühle der Postmoderne fanden sich - besonders in Frankreich - einige Nachahmer Nietzsches, die nach Megill auch den Namen eines prophet of extremity verdienten. Es handelt sich natürlich um Michel Foucault und Jacques Derrida. In Deutschland dagegen wirkte ein großer Existenzialist - Martin Heidegger, der philosophischer als Nietzsche die Philosophie des Subjekts zu verabschieden suchte. Obwohl so viele Ideen in der Postmoderne die nietzscheanische Provenienz aufweisen, beharrt Baran zu Recht darauf, sich die Tatsache bewusst zu machen, dass die Nachmodernen eher lockerer und mit wesentlich geringer Radikalität mit den Metaerzählungen des Autors von Ecce homo verbunden sind, als oft angenommen wird. „Die ästhetische Reduktion der Metaphysik und die somatische Reduktion der Epistemologie“،76 wurden zwar als philosophische Themen von den Poststrukturalisten aufgegriffen und fungierten nicht selten als Hintergrund für die postmoderne Literatur, die allgemeine Einstellung der Postmoderne war jedoch gar nicht darauf bedacht, den nietzscheanischen Weg zum Gewinn der Qualitäten eines Übermenschen anzuvisieren. Das Interesse für das Fragmentarische, Unbestimmte und die Pflege der Inkommensurabilität der Diskurse gab den Ausdruck der leichteren Komponente Nietzsches Konzepte. ${ }^{77}$ Eine radikale Um- und Fortsetzung seiner Ideen mündete in die Partikularisierungstendenz, in Folge deren „vor den allgemeingültigen Begriff [...] der Signifikant [und] vor das nach Allgemeinheit strebende Subjekt der (Sprach-)Körper [tritt].“78

$\mathrm{Zu}$ scharf konturiert schienen Nietzsches Ideen zu sein, um sie in toto in eine Epoche zu integrieren, deren Ernst sich in einem intertextuellen Spiel auflöste, zu stark demaskierend, zu erfinderisch und $\mathrm{zu}$ schlagartig die Offenbarungen für einen Geist, dessen faule (Gemüts)Bewegungen sich nur noch „im Kummulieren von ,kleinen“ Erkennungen, in

\footnotetext{
${ }^{75}$ So betitelte er auch sein Buch: Prophets of Extremity. Nietzsche, Heidegger, Foucault, Derrida, Berkeley-Los Angeles-London 1985.

${ }^{76}$ Bogdan Baran, Postnietzsche, S. 240 („Redukcja estetyczna metafizyki i redukcja somatyczna epistemologii”)

${ }^{77}$ Vgl. ebd., S. 240.

${ }^{78}$ Peter Zima, Das literarische Subjekt: Zwischen Spätmoderne und Postmoderne, Tübingen und Basel 2001, S. 237.
} 
Versuchen, fremde Blicke heimlich zu beobachten““79, erschöpfen. Es mag aber verwundern, dass die subversive Arbeit eines Philosophen dermaßen wirksam sein sollte, um den Niedergang einer etwa 200-jährigen Epoche herbeizuführen. Nietzsche gilt als derjenige, der sich der Vollendung der Moderne in den Weg stellte, der diese gar zu stoppen wusste. Es ist zwar kaum möglich, die schwierig greifbaren, subtilen Mechanismen, die die Emanzipation der Vernunft zunichtemachten, genau zu rekonstruieren, wir können jedoch die Argumentation derjenigen reflektieren, die die Vollendung der Moderne als immer noch möglich und sinnvoll erklären. Das Projekt der Vollendung einer Epoche, die bereits ihren Geist aufgegeben hat, scheint ein nahezu wahnsinniges Unterfangen verwirklichen zu wollen. Schlimmstenfalls wird aber dieser mutige Versuch zu einem Sprachspiel unter vielen, über dessen Popularität seine ästhetische Wirkung entscheiden wird. Eine radikale Korrektur der Postmoderne ist kaum vorstellbar, da die radikale Pluralität nicht reversibel ist. Eine moderate Korrektur müsste entweder bei der Pluralität manipulieren, mit dem Ziel, ihre Zerstreuung zu verringern oder das korrektive Sprachspiel so weit wie möglich stärken, um einige Kulturund/oder Wissenschaftsbereiche für sich zu gewinnen.

\footnotetext{
${ }^{79}$ Maria Anna Potocka, Manieryzm po modernizmie [Manierismus nach der Moderne] In: Postmodernizm. Teksty polskich autorów [Die Postmoderne. Die Texte polnischer Autoren], Kraków 2003, S. 151. („,w kumulowaniu 'małych' rozpoznań, w próbach podglądania cudzych spojrzeń")
} 


\subsection{Jürgen Habermas' Konsens vs. Jean-François Lyotards Dissens oder der ,einzig wahre' Streit um die Postmoderne}

„Unbestreitbar mischt sich ein Bestandteil von Glück in jede Kehrtwendung; man schöpft daraus sogar einen Kraftüberschuß: Verleugnung verjüngt. ${ }^{\prime 80}$ Möchte man mit diesen Worten für den Einzug einer neuen Epoche werben, so fände man ohne Zweifel genauso viele Begeisterte wie Skeptiker. Retrospektiv ließe sich dann die Richtigkeit dieser Einsicht, dieser eigentlich für das einzelne Schicksal gedachten Worte, in dem Makrokontext des kulturellen Wandels überprüfen. Aber selbst hier, d.h. rückblickend, wird die Einschätzung des Geschehenen sehr unterschiedlich ausfallen, Entwicklungen und Tendenzen, die in einigen Intellektuellenkreisen willkommen und affirmiert werden, werden von den anderen Kulturtheoretikern heftig kritisiert oder sogar dämonisiert. Auf welcher Seite der Barrikade man sich (ab)findet, scheint im zunehmenden Maße davon abhängig zu sein, für welche Art Argumentation man anfällig ist, d.h. auf welche Art und Weise ästhetisierte Ideen als überzeugender erscheinen. Ein perfektes Beispiel einer indirekten Auseinandersetzung zweier prominenter Theoretiker der Postmoderne liefern Jürgen Habermas und Jean-François Lyotard. In seiner 1980 gehaltenen und bald berühmt gewordenen Rede aus Anlass der Verleihung des Adorno-Preises, die mit dem Titel Die Moderne - ein unvollendetes Projekt versehen wurde, formulierte Habermas - erst ansatzweise - seine scharfsinnige, komplexe und nuancenreiche Diagnose des epochalen Wandels. Der Erbe der philosophischen Frankfurter Schule zeigte bald, dass er das Hauptpostulat seiner Rede, dass das Projekt der Moderne nicht verworfen werden müsse, sondern durch die aus den Verirrungen gezogene Lehre neu durchdacht werden solle ${ }^{81}$, sehr ernst nimmt. Die in den 80er Jahren von ihm geschriebenen Bücher, Der philosophische Diskurs der Moderne und Die neue Unübersichtlichkeit, lieferten weitere detaillierte Beobachtungen zur Lage der abendländischen Kultur, Philosophie und Gesellschaft. Die Frankfurter Rede Habermas', sehr ausgewogen verfasst, mit einer gemäßigten Dosis Kritik und zahlreichen Ausführungen, die seinen Scharfsinn für Rekonstruktionen kulturell-philosophischer Mechanismen bezeugten, hätte wahrscheinlich kein großes Aufsehen erregt, wenn er die Anhänger mancher nachmodernen Tendenzen in den Geisteswissenschaften nicht als Neokonservative etikettiert

\footnotetext{
${ }^{80}$ Emile M. Cioran, Der Absturz in die Zeit, Stuttgart 1980, S. 131.

${ }^{81}$ Vgl. Jürgen Habermas, Die Moderne - ein unvollendetes Projekt, In: Wolfgang Welsch (Hg.), Wege aus der Moderne, Weinheim 1988, S. 189.
} 
hätte. In einer ausgeklügelten Typologie konnte Habermas drei Typen konservativer Positionen unterscheiden:

„Lassen Sie mich den Antimodernismus der Jungkonservativen vom Prämodernismus der Altkonservativen und dem Postmodernismus der Neukonservativen kurz unterscheiden. Die Jungkonservativen machen sich die Grunderfahrung der ästhetischen Moderne, die Enthüllung der dezentrierten, von allen Beschränkungen der Kognition und der Zwecktätigkeit, allen Imperativen der Arbeit und der Nützlichkeit befreiten Subjektivität zu eigen - und brechen mit ihr aus der modernen Welt aus. [...] Die Altkonservativen lassen sich von der kulturellen Moderne gar nicht erst anstecken. Sie verfolgen den Zerfall der substanziellen Vernunft, die Ausdifferenzierung von Wissenschaft, Moral und Kunst, das moderne Weltverständnis und deren nur noch prozedurale Rationalität mit Mißtrauen und empfehlen [...] eine Rückkehr zu Positionen vor der Moderne. [...] Die Neokonservativen verhalten sich zu den Errungenschaften der Moderne noch am ehesten affirmativ. Sie begrüßen die Entwicklung der modernen Wissenschaft, soweit diese ihre eigene Sphäre nur überschreitet, um den technischen Fortschritt, das kapitalistische Wachstum und eine rationale Verwaltung voranzutreiben. Im Übrigen empfehlen sie eine Politik der Entschärfung der explosiven Gehalte der kulturellen Moderne.“ ${ }^{\text {(82 }}$

Die auf den ersten Blick nicht ganz klare Assoziation des Konservatismus mit den Positionen z.B. der französischen Postmodernen (von denen Habermas einige namentlich nennt) wird erst dann einleuchtend, wenn man ihm zustimmt, dass die Verwerfung des aufklärerischen Ideals der Rationalität und somit der Errungenschaften der Moderne als konservativ einzustufen sei. ${ }^{83}$ Diesen Konservatismen stellt der Frankfurter Philosoph seine Konzeption des kommunikativen Handelns entgegen, dessen Fundament der Konsens bildet. Im Fokus seiner Theorie stehen ,kommunikativ strukturierte Lebenswelten, die sich über das handgreifliche Medium verständigungsorientierten Handelns reproduzieren." 84 Der Optimismus Habermas' angesichts der Möglichkeit der Fortsetzung und Vollendung des Projekts der Moderne hatte seine Quelle in der positiven Einschätzung der Fähigkeit der

\footnotetext{
${ }^{82}$ Ebd., S. $191 f$.

${ }^{83}$ Vgl. Bogdan Baran, Postmodernizm i końce wieku [Der Postmodernismus und die Enden des Jahrhunderts], S. 209-211.

${ }^{84}$ Jürgen Habermas, Der philosophische Diskurs der Moderne, Frankfurt am Main 1985, S. 345. Gerade in den Lebenswelten lokalisierte Habermas den Bereich, der im Zuge des gesellschaftlich-kulturellen Wandels durch Verarmung bedroht sei. Diese Bedrohung resultiere, seiner Meinung nach, aus zwei gleichzeitig verlaufenden Tendenzen: „Die professionalisierte Bearbeitung der kulturellen Überlieferung unter jeweils einem abstrakten Geltungsaspekt lässt die Eigengesetzlichkeiten des kognitiv-instrumentellen, des moralisch-praktischen und des ästhetisch-expressiven Wissenskomplexes hervortreten. [...] Auf der anderen Seite wächst der Abstand zwischen den Expertenkulturen und dem breiten Publikum. Was der Kultur durch spezialistische Bearbeitung und Reflexion zuwächst, gelangt nicht ohne weiteres in den Besitz der Alltagspraxis. Mit der kulturellen Rationalisierung droht vielmehr die in ihrer Traditionssubstanz entwertete Lebenswelt zu verarmen." Jürgen Habermas, Die Moderne - ein unvollendetes Projekt, a.a.O., S. 184.
} 
emanzipierten Vernunft zur Selbstkorrektur. Anders als Nietzsche und die Befürworter seiner extremen Philosophie, die die rationale Vernunft als den Ort der Gewaltkonstitution verwarfen und seine Arbeit der Aufwertung der Unvernunft widmeten, konzentrierte sich Habermas auf die Ausarbeitung der Bedingungen für eine auf den Konsens zielende intersubjektive Kommunikation. Seine Vision einer moderaten Integration wurde bald mit dem Unglauben an die Möglichkeit der Übereinstimmung und zugleich mit der Angst vor irgendeiner Vereinheitlichung konfrontiert. ${ }^{85}$ Diese Anti-Konsens-Position wurde zum Programm eines der prominentesten Diagnostiker der Postmoderne - Jean-François Lyotard. Das Prinzip des Konsenses als Gültigkeitskriterium wurde von ihm als nicht mehr genügend erklärt:

„Entweder ist er die durch den Dialog erzielte Übereinstimmung von Menschen als erkennende Intelligenzen und freie Willen. [...] Diese Konzeption beruht aber auf der Gültigkeit der Emanzipationserzählung. Oder der Konsens wird vom System als eine seiner Komponenten zum Zweck der Aufrechterhaltung und Verbesserung seiner Performanzen manipuliert. [...] Er gilt also nur als Mittel für das wahre Ziel, welches das System legitimiert, die Macht."

Lyotards Plädoyer für die Verwerfung des Konsenses resultierte aus seiner aufmerksamen und aufschlussreichen Beobachtung der Mechanismen, die den Einzug der Postmoderne begleitet haben. Um seine Kritik am Habermasschen Modell in ihrer Komplexität zu verstehen, müssen die wichtigsten Thesen und Schlussfolgerungen des französischen Philosophen angeführt werden. Der Autor von Das postmoderne Wissen untersuchte die konflikthaften Beziehungen zwischen der Wissenschaft und der ,Erzählung ' und lokalisierte das kritische Moment in der Legitimierung der Regeln, die die Wissenschaft vollziehen muss. Der legitimierende Diskurs müsse dabei auf eine große Erzählung, ,wie die Dialektik des Geistes, die Hermeneutik des Sinns, die Emanzipation des vernünftigen oder arbeitenden Subjekts“ ${ }^{* 87}$, bezogen werden. Dieser für die Moderne spezifische Mechanismus wurde nach Lyotard mit zunehmender Skepsis angesehen, die Abwertung der Metaerzählungen könne als logische Folge der Krise der Metaphysik und der Institution der Universität verstanden werden. Die große Erzählung „zerstreut sich in Wolken, die aus sprachlich-narrativen, aber auch denotativen, präskriptiven, deskriptiven usw. Elementen bestehen, von denen jedes pragmatische Valenzen sui generis mit

\footnotetext{
${ }^{85}$ Vgl. Anna Burzyńska, Postmoderna: pomiędzy Wieżq Babel a Bibliotekq Babel [Zwischen dem Babelturm und der Babelbibliothek], in: Postmodernizm. Teksty polskich autorów [Die Postmoderne. Die Texte polnischer Autoren], Bunkier Sztuki inter esse, Kraków 2003, S. 63.

${ }^{86}$ Jean-François Lyotard, Das postmoderne Wissen, Graz Wien 1986, S. $175 f$.

${ }^{87}$ Ebd., S. 13.
} 
sich führt. [...] Es gibt viele verschiedene Sprachspiele - das ist die Heterogenität der Elemente.

Sie führen nur mosaikartig zur Institution - das ist der lokale Determinismus." $\$ 8$

Der Abschied von den Metaerzählungen stellte jedoch das Problem der Legitimierung des Wissens und der Wissenschaft in ein neues Licht. In verwirrenden Ausführungen analysiert Lyotard die wissenschaftliche und gesellschaftliche Pragmatik und das Fazit seiner Untersuchungen lässt ihn in der Suche nach Legitimierungsmöglichkeiten eindeutig auf die Idee des Konsenses verzichten. Der Optimismus Habermas' sei nämlich, wie es der französische Philosoph behauptete, auf zwei Annahmen fundiert, die sich kaum verwirklichen lassen:

„Erstens, daß alle Sprecher über Regeln oder über die für alle Sprachspiele universell gültigen Metapräskriptionen einig werden können, obwohl diese selbstverständlich heteromorph sind und heterogenen pragmatischen Regeln zugehören. Die zweite Voraussetzung ist, daß die Finalität des Dialogs der Konsens ist. Wir haben aber mit der Analyse der wissenschaftlichen Pragmatik gezeigt, daß der Konsens nur ein Zustand der Diskussionen und nicht ihr Ziel ist. Dies ist vielmehr die Paralogie." $" 89$

Wenn also nicht Konsens, dann wird Dissens in der Postmoderne zum Ziel jedes Diskurses. Wie verhält es sich aber mit der Frage der Gerechtigkeit, die Lyotard nach dem Abschied vom Konsens zu retten sucht? Den ersten Schritt zur Lösung dieses Dilemmas sieht er im Erkennen der Heteromorphie der Sprachspiele. Sollte es irgendwo einen Konsens über die Regeln, die das jeweilige Spiel und seine Spielzüge definieren, geben, so muss es ein lokaler Konsens sein. ${ }^{90}$ Die neue Orientierung akzeptiert und fördert die Vielfalt der (Meta)Argumentationen und sie „entspricht der Evolution der sozialen Interaktionen, wo der zeitweilige Vertrag die permanente Institution in beruflichen, affektiven, sexuellen, kulturellen, familiären und internationalen Bereichen wie in den politischen Angelegenheiten tatsächlich ersetzt." 91

\footnotetext{
${ }^{88}$ Ebd., S. 14f. Welsch macht darauf aufmerksam, dass die Skepsis gegenüber den Metaerzählungen die Tatsache betraf, dass „ihre Form hinfällig wurde“, was nicht sofort bedeuten musste, „dass ihre Inhalte antiquiert wären. Die Form der Meta-Erzählung, die alles theoretische und praktische Verhalten einer Epoche als Leitidee zu umgreifen und zu dirigieren vermochte, ist obsolet geworden." Wolfgang Welsch, Unsere postmoderne Moderne, Weinheim 1987, S. 172.

${ }^{89}$ Ebd., S. 189f. „Was mit dieser doppelten Feststellung (Heterogenität der Regeln Analysen der Nichtübereinstimmung) verschwindet, ist eine Überzeugung, die noch die Forschungsarbeit von Habermas belebt, nämlich daß die Menschheit als kollektives (universelles) Subjekt ihre gemeinsame Emanzipation mittels der Regelung in allen Sprachspielen erlaubter ,Spielzüge' anstrebt und daß die Legitimität einer beliebigen Aussage aus ihrem Beitrag zu dieser Emanzipation besteht. “ Ebd., S. 190.

${ }^{90}$ Vgl. Ebd., S. 191. „das heißt von gegenwärtigen Mitspielern erreicht und Gegenstand eventueller Auflösung.“ ${ }^{91}$ Ebd.
} 
Lyotard, anders als Habermas, der drei Beziehungsarten zur Moderne unterschied, um den Geist der Nachmoderne näherzubringen, gewann den Begriff der Postmoderne ,aus einer Reflexion auf die Eigenart modernen Wissens.“ 92 Mit der Verwerfung der Metaerzählungen als Legitimierungsgrundlagen begrüßt er die radikale Pluralität und weiß ihre Vorteile gegenüber der modernen Vereinheitlichungsobsession zu verteidigen. Der französische Neokonservative, wie ihn Habermas gerne sieht, erinnert an Adornos Worte, „die Erfahrung im hegelschen Sinne (die Verwirklichung des Geistes in der Geschichte) endet nach Auschwitz ${ }^{\text {‘93 }}$, und die einzige Lehre, die aus diesem gescheiterten Projekt zu ziehen sei, sei die Verkündung des Zeitalters des Experimentierens, der Vervielfachung der Mikrologien. ${ }^{94}$ Die Kluft, die Lyotard von Habermas trennt, ist der Ausdruck ihrer unterschiedlichen Diagnosen des Scheiterns der Moderne und dessen, was nach dem Fiasko ihres Projekts noch zu retten ist. Die Strategie des Frankfurter Philosophen scheint darauf zu beruhen, die Trümmer einer Wirklichkeit zu erkunden, um zu sondieren, was „noch urbar oder wieder urbar zu machen ist." ${ }^{95}$ Diese Trümmererkundung nimmt eben an, dass das Projekt der Moderne unvollendet bleibe. Für Lyotard ist jedoch die Moderne „nicht ,unvollendet', sondern sie wurde ,liquidiert', [weil] die Hoffnungen, die sich mit der Moderne verbanden [...] nach Auschwitz und dem Stalinismus [nicht] erfüllt worden sind [...], sondern zerstört." ${ }^{96}$ Der französische Philosoph sieht daher keinen Sinn in der Melancholie der Moderne, er hält auch nichts von der zynisch-eklektischen Postmoderne des anything goes. Im Sinne der Avantgarden möchte er die Kraft des Postmodernen im Experimentieren sehen, „das schon Dagewesene nicht [...] wiederholen, sondern weitergehen im Hinterfragen der Regeln von Kunst. “97

Manch eine(r) würde gerne wissen, welcher dieser prominenten Geisteswissenschaftler Recht hat, wessen Argumente treffender den Nerv des epochalen Wandels zu treffen scheinen und letztlich, wessen Plädoyer für die Nachmoderne sich überzeugender anhört. Eine treffende Diagnose des kulturell-gesellschaftlichen Wandels liefert meines Erachtens Lyotard und zwar nicht nur, weil er das Plurale, Heterogene, Paralogische begrüßt und Habermas als den Spielverderber bloßstellt. Die Affirmation des Dissenses repräsentiert schlicht und

\footnotetext{
${ }^{92}$ Wolfgang Welsch, Unsere postmoderne Moderne, S. 32.

93 Jean-François Lyotard, Essays zu einer affirmativen Ästhetik, Berlin 1982, S. 7.

${ }^{94} \mathrm{Vgl}$. ebd. $7 f$.

${ }^{95}$ Jean-François Lyotard, Immaterialität und Postmoderne, Berlin 1985, S. 37.

${ }^{96}$ Ebd., S. 37f. Einer möglichen Vollendung des Projektes der Moderne gibt Lyotard keine Chance: „Auf den Ruinen dieses Projekts [...] wird man nichts wiederaufbauen können. Man muss die Hoffnungslosigkeit als solche hinnehmen, von ihr im Denken ausgehen und sich leiten lassen." Ebd., S. 38.

${ }^{97}$ Ebd., S. 39.
} 
ergreifend eine Position, die in fast jedem kulturellen Bereich als attraktiver als konsensorientierte Handlungen, als eine auf den Konsens zielende Kommunikation empfunden wird. Die Befreiung von der Notwendigkeit der Konsensbestrebungen zeigte sich m.E. als kreativitätsfördernd und lässt subtile Machtverhältnisse in geisteswissenschaftlichen Diskursen effektiv unterlaufen. Manche Thesen Lyotards gelangen jedoch an jene Grenze, hinter der jede Diskussion nur noch als sinnlos erscheinen muss. Ich möchte dies an zwei Beispielen veranschaulichen. Wenn man z.B. behauptet, nach den dramatischen Erfahrungen der Totalitarismen des 20. Jahrhunderts sei nur noch dieses oder jenes möglich, setzt man damit ein Ende jeder Diskussion, die argumentativ verlaufen sollte. Solche Behauptung wirkt nämlich sehr subjektiv und persönlich, und macht somit eher den Eindruck einer Geschmacksurteilsäußerung. So darf also Lyotard behaupten, nach Auschwitz sei nur noch die permanente Hoffnungslosigkeit hinzunehmen, wobei Habermas dabei mitnichten an die Liquidierung der Aufklärungspotentiale denkt. Vernünftig diskutieren lässt sich darüber nicht. Ähnlich verhält es sich meines Erachtens mit der Frage des Konsenses. Die Vorstellung von einem Konsens wird notwendig mit irgendeiner Ordnung verbunden und jeder geordnete Zustand weist eine niedrigere Dynamik auf als ein chaotischer Übergangszustand. Die Ordnung als solche passt daher gar nicht in die (Reihe der) Lyotardschen Charakteristika der Postmoderne, wie Pluralität, Inkommensurabilität, Heterogenität, weil sie einfach die spielhafte Experimentierfreude stören würde. Jeder eventuelle Konsens sollte also durch einen Dissens ersetzt werden.

Der von Habermas und Lyotard initiierte Streit um die Postmoderne hat in den 80er Jahren an Intensität zugenommen. Die besonders von den französischen Intellektuellen betriebene Ästhetisierung ihrer theoretischen Schriften führte $\mathrm{zu}, \mathrm{a}$ massiv over-emphasis on the aesthetic, the retorical, or ,world-disclosive“ dimension of language and a consequent failure to make room for those other (truth-related or ethico-evaluative) dimensions which are thereby consigned to a merely derivative and ancillary status." 98

\footnotetext{
${ }^{98}$ Christopher Norris, Deconstruction and the 'Unfinished Project of Modernity', London 2000, S. 50.
} 


\subsection{Postmoderne - das Zeitalter der permanenten Ästhetisierung}

Die Bemerkungen, „die Postmoderne zeigt eine besondere Affinität zu ästhetischen Phänomenen, [und] [...] heute [ist] fast nur noch ästhetisches Denken zum Begreifen der Wirklichkeit in der Lage“999, bestimmen, wie es scheint, die wichtigste Perspektive, aus der man die Nachmoderne reflektieren könnte. Ob es richtig ist, wie es Wolfgang Welsch tut, dem ästhetischen Denken die Erkenntniskompetenz zuzuweisen, angesichts des angeblichen Scheiterns des begrifflichen Denkens, darüber lässt sich streiten. Die Idee selbst - das ästhetische Denken zum ,probaten Orientierungsmedium“ in der Postmoderne zu erklären scheint mir zugleich originell und riskant zu sein. Die zusätzliche Behauptung, ,seine Konjunktur ist Effekt nicht einer Mode, sondern einer normativen Lage“100, sollte jedoch mit einer Begründung belegt werden, die eine interdisziplinäre Untersuchung fundieren müsste. Die Welschsche Affirmation des ästhetischen Denkens erinnert nicht ohne Grund an Lyotard und an Strategien der Ästhetisierung des theoretischen Diskurses, die nach dem Niedergang der Moderne eine Blütezeit erfahren haben. Eine präzise und einleuchtende Auffassung dieses Phänomens formulierte - im Gegensatz zu Welsch jedoch nicht affirmativ, sondern kritisch Rudolf Burger:

„Was in postmodernen Texten als konstatives Urteil über einen Sachverhalt auftritt, sich aufspreizt als Ergebnis eines vorausliegenden, aber nie explizit gemachten, propositionalen Denkens, ist im Kantischen Sinn nur scheinbar, durch seine objektivierende Form, Ausdruck der bestimmenden, in Wahrheit fast immer ein Ausdruck der reflektierenden Urteilskraft - das heißt die Zustimmung wird, kantisch gesprochen, ,angesonnen'. Der postistische Autor sondert Geschmacksurteile ab, denen er die Form der Theorie gibt.“101

Nicht umsonst machte die Ästhetisierung innerhalb des Theoretischen einem Philosophen vom Format eines Habermas Sorgen. Diese Tendenz und ihre Konsequenzen konnte er - in ihrem noch latenten Stadium - bei seinen Lehrern Horkheimer und Adorno aufspüren und demaskieren. Wie unwiderstehlich müsste Nietzsches Inspiration sein, dass sie die Autoren

\footnotetext{
${ }^{99}$ Wolfgang Welsch, Einleitung, In: Wolfgang Welsch (Hg.), Wege aus der Moderne, S. $40 \mathrm{Of}$.

${ }^{100}$ Ebd., S. 42. Welsch beschäftigt sich sehr intensiv mit der Ästhetik und seine Ideen basieren auf der Behauptung, das Ästhetische durchdrang bereits zu den Fundamenten des Denkens. Er lieferte viele originelle Beobachtungen zu dieser Problematik, leider sind manche seiner Ausführungen nicht ganz einleuchtend. Im Fazit dieser Arbeit versuche ich in Kürze ein paar Kritikpunkte zu schildern.

${ }^{101}$ Rudolf Burger, Das Denken der Postmoderne. Würdigung einer Philosophie für Damen und Herren, in: Albert Berger, Gerda Elisabeth Moser (Hg.), Jenseits des Diskurses. Literatur und Sprache in der Postmoderne. S. $35 f$. Somit diagnostiziert Burger eine doppelte Ästhetisierung im postmodernen Denken: „[die] Ästhetisierung der Sachen und der Gestalt ihrer Theorie."
} 
der Dialektik der Aufklärung dermaßen überwältigte, „,dass sie ihre kulturkritischen Maßstäbe aus einer verselbständigten Grunderfahrung der ästhetischen Moderne gewinnen“"102 und sich dabei eine solche Geringschätzung des ,vernünftigen Gehalt[s] der kulturellen Moderne [erlauben, dass] sie einer hemmungslosen Vernunftskepsis“103 erlagen. Was Habermas bei den Frankfurter Philosophen zu brandmarken suchte, wurde bald zum Markenzeichen einer neuen Kultur, zum Phänomen, das sich ungehemmt auf alle Geisteswissenschaften verbreiten konnte. Der neue Trend sollte die Akzente im diskursiven Herausarbeiten von philosophischen, kultur- und literaturwissenschaftlichen Themen verschieben, solide mit klaren Argumenten geführte Auseinandersetzungen gaben nicht selten dem rhetorischen Glanz der Formulierungen oder kaum diskutierbaren Ideen nach. Besonders gut lässt sich die wuchernde Ästhetisierung in den Literaturwissenschaften beobachten, in den Versuchen, die nachmoderne Literatur in der Opposition zu der modernen zu charakterisieren. ${ }^{104}$

Einige Beispiele von Konzepten, die einen mangelhaften Nutzen für das Verständnis der Mechanismen der Konstituierung der postmodernen Literatur hatten, nannte der von mir bereits erwähnte Brian McHale. Es sind unter anderem die Arbeiten von David Lodge und Ihab Hassan, deren Aufzählungen der Merkmale der nachmodernen literarischen Texte keinen Aufschluss darüber geben können, „how the literary system has managed to travel from the state reflected in the catalogue of modernist features to the state reflected in the postmodernist catalogue." ${ }^{105}$ Die Arbeiten Hassans stellen meines Erachtens ein Beispiel eines (immer öfter betriebenen) nachmodernen ästhetisierenden Umgangs mit kulturwissenschaftlichen Inhalten dar. Seine Absicht, ein kulturelles Feld zu umschreiben, meinte er durchgeführt zu haben, indem er eine Merkmalreihe für die Postmoderne erarbeitete, wobei die von ihm gewählten

\footnotetext{
102 Jürgen Habermas, Der philosophische Diskurs der Moderne, Frankfurt am Main 1985, S. 146.

${ }^{103}$ Ebd., S. 146 u. 156.

${ }^{104}$ Ein Handvoll guter Beispiele liefert Peter Zima in Moderne/Postmoderne: Gesellschaft, Philosophie, Literatur, Francke Verlag, Tübingen Basel 2001, S. 240-251.

${ }^{105}$ Brian McHale, a.a.O., S. 7. „David Lodge lists five strategies (contradiction, discontinuity, randomness, excess, short circuit) by which postmodernist writing seeks to avoid having to choose either of the poles of metaphoric (modernist) or metonymic (antimodernist) writing. Ihab Hassan gives us seven modernist rubrics (urbanism, technologism, dehumanization, primitivism, eroticism, antinomianism, experimentalism), indicating, how postmodernist aesthetics modifies or extends each of them." Auf einen weiteren wenig überzeugenden Versuch Hassans, „Moderne und Postmoderne anhand von stilistischen Merkmalen zu unterscheiden [...]“, machte auch Zima aufmerksam. S. Peter Zima, Das literarische Subjekt, S. IX.

Wenig einleuchtende literaturwissenschaftliche Beiträge zur postmodernen Literatur konnte man aber schon wesentlich früher antreffen. Bereits im Jahre 1959 nahm man in den USA den Niedergang der literarischen Moderne wahr und angesichts des anfänglichen Misstrauens und der Abneigung gegenüber dem Neuen wertete man die neue Literatur als eine „durch Erschlaffung, durch ein Nachlassen der innovatorischen Potenz und Durchschlagskraft gekennzeichnet[e]“ ab. Vgl. Wolfgang Welsch, Unsere postmoderne Moderne, a.a.O., S. 14f. Diese triste Erstdiagnose der amerikanischen Literaturwissenschaftler Irving Howe und Harry Levin lässt sich, wie ich meine, leicht rechtfertigen: Erstens gab es um diese Zeit noch kaum postmoderne Literatur, zweitens orientierten sich die Beiden an prominentesten Werken der ersten Dekaden des 20. Jahrhunderts.
} 
Beispiele eine persönliche Auswahl darstellten und die definitorischen Versuche mit Überschneidungen und Widersprüchen rechnen sollten. ${ }^{106}$ Für literaturwissenschaftliche Untersuchungen ist die Liste Hassans leider kaum brauchbar. Die von ihm signalisierte Möglichkeit von Widersprüchen müsste zuerst als die Schwäche des Konzeptes gesehen werden, um diese scheint sich jedoch der Autor nicht weiter zu kümmern. In den kurzen Charakteristika der vorgeschlagenen Merkmale finden wir eine Reihe von Ergänzungen, sei es in Form von Synonymen, sei es als Assoziationen mit anderen Merkmalen und Konzepten. Die Hauptstichwörter werden dadurch in seinen Bedeutungen leider nicht konkretisiert, sondern immer weiter nach außen hin verknüpft. Durch die Gegenüberstellung von Oppositionen, wie „Metonymie statt Metapher“ entstehen unzulässige Vereinfachungen und ein auch in diese Oppositionenreihe hineinmontiertes Paar: „Schizophrenie statt Paranoia“ suggeriert eine verblüffende Behauptung, die beiden anomalen Geisteszustände könnten wirklich als treffende Metapher für das Umschreiben der Kulturzustands zweier Epochen fungieren. Die von Hassan erarbeitete Liste lässt sich auch beliebig erweitern, die in sein Konzept bereits einprogrammierten Überschneidungen werden seinen Beitrag jedoch qualitativ nicht mehr verändern können. Eine spontane Verflechtung von inkommensurablen Ideen und heterogenen Diskursen „füg[t] sich zusammen zu einer irrationalen Größe, vielleicht sogar $\mathrm{zu}$ etwas Absurdem“107, fasst Hassan vorsichtshalber seine chaotische Darstellung zusammen. Sein Text schillert, spielt mit einer kunterbunten Ästhetik, will alles bieten außer der Einsicht in das im Titel stehende Thema.

Es wäre bestimmt nicht gerecht, Beiträge dieser Art als wertlos und/oder nutzlos zu qualifizieren, man muss sich jedoch darüber im Klaren sein, dass sie sich eher im Bereich der Geschmacksäußerungen situieren als Resultate tiefgründiger (geistes)wissenschaftlicher Untersuchung darstellen. Die Auffassungen in solcher Form scheinen uns daran zu erinnern, dass „die Wahrhaftigkeit der gegebenen Auffassung nicht in Betracht gezogen wird, [...][dass] die Vielheit nicht den theoretischen, sondern den ästhetischen Wert hat.“ ${ }^{\text {108 }}$

Lässt sich also die Literatur der Postmoderne noch einigermaßen präzis beschreiben oder entzieht sie sich jeder eindeutigen Konzeptualisierung, weil sie so unterschiedlich ist,

\footnotetext{
${ }^{106}$ Vgl. Ihab Hassan, Postmoderne heute, in: Welsch, Wege aus der Moderne, a.a.O., S. 48. Die Liste beinhaltet elf Merkmale: 1. Unbestimmtheit oder genauer gesagt Unbestimmtheiten. 2. Fragmentarisierung. 3. Die Auflösung des Kanons. 4. Der Verlust von „Ich“, von „Tiefe“. 5. Das Nicht-Zeigbare, Nicht-Darstellbare. 6. Ironie. 7. Hybridisierung oder die Reproduktion von Genre-Mutationen, unter ihnen Parodie, Travestie, Pastiche. 8. Karnevalisierung. 9. Performanz, Teilnahme. 10. Konstruktcharakter. 11. Immanenz. Vgl. ebd., S. 49-55.

${ }^{107}$ Ebd., S. 56.

108 Bogdan Baran, Postnietzsche, S. 219. [„Prawdziwość danego ujęcia nie jest brana pod uwagę, [...] wielość nie ma waloru teoretycznego, lecz estetyczny."]
} 
stilistisch und intertextuell experimentiert und mit vielen Bausteinen der Kultur jongliert? Macht etwa die postmoderne Entgrenzung des Ästhetischen jeden Versuch der Hervorbringung der der Geisteshaltung zugrunde liegenden, subtilen diskursiven Mechanismen zunichte und konzentriert die Mühen geisteswissenschaftlicher Reflexion auf das bloße Einschleifen des rhetorischen Glanzes der Ausführungen?

Das oft signalisierte Problem der Analysen der nachmodernen literarischen Texte betrifft die Einschätzung, ob die untersuchte Prosa als schon postmodern oder noch modern einzustufen sei. Eine Art erste Hilfe bekommen wir bestimmt mit der Sondierung der bereits erwähnten Dominante, eines Kriteriums, das sich in den Analysen Brian McHales als nützlich erwiesen hat. Mit der Annahme, in einem postmodernen Werk wird der Leser betont mit Fragen ontologischer Natur konfrontiert und mit der Vermutung, die wuchernde Ästhetisierung des nachmodernen Zeitalters müsste auch in der Literatur ihren Ausdruck gefunden haben, gewinnen wir eine Perspektive, aus der die literaturwissenschaftliche Untersuchung starten könnte. Folglich kann die Affirmation des Oberflächlichen ${ }^{109}$ erwartet werden, die als die logische Konsequenz des Verlusts der Tiefe permanent hervorgehoben wird. Dieses wird einen gravierenden Einfluss auf die Bedeutungsstiftung und die Konstruktion der Subjektivität haben. Gefürchtet werden kann somit der Sinnentzug, ein Versteckspiel der Signifikate und Signifikanten ${ }^{110}$, ein Spiel mit ungleichen Chancen, da der permanenten Zeichenüberflutung die Bedeutungsverknappung gegenübersteht.

Erst solide literaturgeschichtliche Untersuchungen, deren Ziel ist, die graduell verlaufende Umwandlung von der Moderne zur Postmoderne plausibel zu machen, ermöglichen eine präzise Lokalisierung der Momente, die die Spezifik der beiden Epochen ausmachen. Werner Wolf beobachtete in der postmodernen Prosa eine starke histoire-Entwertung, deren Ziel war „ein bewußtes Hinausdrängen des Lesers aus der Geschichte und ihrer Illusion und [...] seine ausschließliche Einstellung auf das Medium, auf den discours und die Reflexion der hier verhandelten, vorwiegend metaästhetischen Probleme.“1111 Peter Zima schrieb der literarischen

\footnotetext{
${ }^{109}$ Dieses Merkmal der Postmoderne überhaupt ist von vielen Geisteswissenschaftlerlnnen betont. Andreas Huyssen diagnostiziert „das Hervortreten einer neuen Flachheit oder Seichtheit, einer neuen Oberflächlichkeit im wortwörtlichen Sinne, die das vielleicht auffälligste formale Charakteristikum aller Spielarten der Postmoderne ist." Andreas Huyssen, Postmoderne - eine amerikanische Internationale, in: Andreas Huyssen, Klaus R. Scherpe (Hg.), Postmoderne. Zeichen eines kulturellen Wandels, Reinbek bei Hamburg 1986, S. 54.

${ }^{110}$ Ich meine damit das Phänomen, das Klaus R. Scherpe auch als „Entsicherung der Signifikanten“ bezeichnete und das er mit "der Zerstörung der symbolischen Ordnungen“ verbindet. Davon lebt nach Scherpe das postmoderne Denken. Vgl. Klaus R. Scherpe, Dramatisierung und Entdramatisierung des Untergangs - zum ästhetischen Bewußtsein von Moderne und Postmoderne. In: Andreas Huyssen, Klaus Scherpe (Hg.), Postmoderne. Zeichen eines kulturellen Wandels, S. 272.

${ }^{111}$ Werner Wolf, Ästhetische Illusion und Illusionsdurchbrechung in der Erzählkunst. Theorie und Geschichte mit Schwerpunkt auf englischem illusionsstörenden Erzählen, Max Niemeyer, Tübingen 1993, S. 674f.
} 
Postmoderne vor allem „das Bewußtsein von der Austauschbarkeit oder Indifferenz der Werte, Regungen, Handlungen, Aussagen “112 zu. Er listet eine Reihe von Stilbegriffen auf, die sich entweder radikalisierend oder kontrastierend auf die zuvor genannten Stilmerkmale der Moderne beziehen. Angesichts der Unterschiedlichkeit der nachmodernen Prosa, verweist Zima auf konkrete Autoren, bei denen die genannten Charakteristika einen besonders prägnanten Ausdruck gefunden haben. Zu den Erzähltechniken, die erst in der Postmoderne zu verzeichnen sind, zählt Zima unter anderem konkurrierende Erzählerstandpunkte, Auflösung der Gattungsgrenzen und systematische Thematisierung der Leserrolle. ${ }^{113}$

Eine allgemein akzeptierte Theorie der postmodernen Literatur - sei es als Kontrastierung, sei es als Fortsetzung (d.h. Radikalisierung) der Moderne - darf es in der Ära der radikalen Pluralität programmatisch nicht geben. Die Überflutung der dieser Problematik gewidmeten Veröffentlichungen musste jedoch strategisch geordnet werden, die einleuchtenden Auffassungen sollten herausgefischt und in der praktischen, textnahen literaturwissenschaftlichen Arbeit erprobt werden. Monika Fludernik und Jan Alber schätzen Konzepte McHales und Wolfs als eine gelungene narratologische Abgrenzung von Moderne und Postmoderne, sie machen jedoch zugleich darauf aufmerksam, dass auch solche Annäherungsweise mit Schwächen verbunden sei. ${ }^{114}$ Zweifelsohne gehören jedoch die Entwürfe von McHale, Wolf und Zima $\mathrm{zu}$ den überzeugendsten und solidesten literaturwissenschaftlichen Bearbeitungen dieser Problematik. Ein geschicktes, vorsichtiges Umgehen mit den von ihnen gelieferten Ideen kann bestimmt das Gewinnen einer ersten groben Orientierung in der Lektüre eines postmodernen literarischen Textes enorm fördern.

Der zunehmenden Ästhetisierung auf der Ebene der geisteswissenschaftlichen Diskurse entspricht der gewaltige Fortschritt der Entgrenzung des Literarästhetischen. In den folgenden Untersuchungen der von mir als postmodern etikettierten Romane werden zunächst Textstrategien analysiert, die die Ästhetisierungsmechanismen in Gang setzen. Im nächsten Schritt wird das Verwirrungspotential (und folglich das Desorientierungspotential) der Entgrenzung des Literarästhetischen sondiert und beschrieben.

Einen meines Erachtens sehr guten Ansatzpunkt für subtilere Unterscheidungen zwischen den Werken moderner und postmoderner SchriftstellerInnen liefert Christoph Bode in seiner

\footnotetext{
${ }^{112}$ Peter Zima, Moderne/Postmoderne: Gesellschaft, Philosophie, Literatur. Tübingen Basel 1997, S. 254f.

${ }^{113} \mathrm{Vgl}$. ebd. Monika Fludernik und Jan Alber loben Zimas Enwurf für die plausible Hervorhebung der „Doppelmanifestation der postmodernen Literatur als einerseits elitär-experimentell und andererseits konventionell-vermarktbar." Damit sollte Zima "den aporetischen Widerspruch zwischen surfictionists (critifiction) und spielerisch-parodistischen Erzählungen" auflösen. Jan Alber/Monika Fludernik (Hg.), Moderne/ Postmoderne, Trier 2003, S. 7.

${ }^{114}$ Mehr dazu in: Jan Alber/Monika Fludernik, a.a.O., S. 2.
} 
Abhandlung Ästhetik der Ambiguität. Zur Funktion und Bedeutung von Mehrdeutigkeit in der Literatur der Moderne. Das Novum moderner literarischer Kunstwerke sei nach Bode ihre gesteigerte Ambiguität, die dem Thematisieren des Verstehensprozesses und des Bedeutens selbst entspringt ${ }^{115}$ :

„Die Kernfrage ist also, wie weit das Material den Rezipienten zwingt, sich von seinen gewohnten Kodes zu entfernen, will er ein ,vernünftiges Bild‘ geliefert bekommen. Nur dort, wo ihm der gewohnte Zugang so nachdrücklich verwehrt wird, daß er einsieht, mit normalsprachlichen und gewohnten ästhetischen Kodes ist kaum ,etwas zu holen', muß er sich - wenn er nicht die Lektüre abbricht - an die Konstruktion neuer ,sekundärer' (und das heißt: ambiger) Verstehensraster geben. Nur dort, wo solche extreme Vertextung besteht, wird die jedem neuzeitlichen Sprachkunstwerk inhärente primäre Ambiguität (zwischen normalsprachlichem und ästhetischem Kode) transzendiert $\mathrm{zu}$ gesteigerten, sekundären Ambiguität, die ein multiples ästhetisches Entkodieren der ,abstrahierten` Elemente nahelegt." "116

Es ist offenbar, dass die Postmodernen auf die ambiguisierenden Verfahren nicht verzichtet haben. Problematisch ist jedoch die Einschätzung des Grades der Ambiguisierung in der postmodernen Literatur, wenn man bedenkt, dass - wie es Bode überzeugend darlegt - die Ambiguität der Modernen eine bereits extreme und komplexe Ausprägung aufweist. Anders als Bode schreibt Zima den modernen Texten die Ambivalenz ${ }^{117}$ (der Werte, Normen, Handlungen, Aussagen $)^{118}$ zu. In seinem Verständnis des Begriffs wird „die Ambivalenz als dialektische Einheit der Gegensätze ohne Synthese, als Zusammenführung unvereinbarer Werte [...] und als Zusammenwirken einander entgegengesetzter Regungen [...] im

\footnotetext{
${ }^{115}$ Vgl. Christoph Bode, Ästhetik der Ambiguität : zu Funktion und Bedeutung von Mehrdeutigkeit in der Literatur der Moderne, Niemeyer Tübingen 1988, S. 290.

${ }^{116}$ Ebd. Hans S. Reiß fragt danach, was eigentlich das Ziel der modernen Dichter sei, und schlussfolgert: „Nichts anderes, als soviel wie möglich auf einmal zu sagen, also eine Vielfalt von Bedeutung in einem Wort oder in einem Satz oder in einem Abschnitt unterzubringen." Hans S. Reiss, Stil und Struktur im modernen europäischen experimentellen Roman, 1958, S. 211. (zit. nach Bode a.a.O., S. 261.) Im Gegensatz zu den Modernen scheinen die Postmodernen so wenig wie möglich auf einmal sagen zu wollen, ohne jedoch ihren Schreibfluss stoppen zu wollen. Am klarsten wusste diese Absicht Werner Schwab in seinem Motto auszudrücken: „Vernichten, ohne sich anzupatzen." W. Schwab, Vernichten, ohne sich anzupatzen, Interview mit R. Koberg und K. Nüchtern, in: Falter 40 (1992), S. 2. Diese nie dagewesene Zerstörungswut sucht die Sprache gegen sich selbst zu wenden. Vgl. Peter Zima, Ästhetische Negation. Das Subjekt, das Schöne und das Erhabene von Mallarmé und Valéry zu Adorno und Lyotard, Würzburg 2005, S. 198. Ich würde das für die Beschreibung der postmodernen Strategien sehr treffende Motto Schwabs noch präzisieren und sagen: Zerstören, ohne sich mit dem Sinn/der Bedeutung anzupatzen.

117 ,Ambivalenz' meint generell Doppelwertigkeit und Bipolarität und findet ihre häufigste Verwendung in der Psychiatrie im Kontext der psychopathologischen Gefühlsregungen. ,Ambiguität' ist als Zweideutigkeit zu verstehen und „bezeichnet [...] einen (referentiellen, semantischen oder auch syntaktisch bedingten) Mangel an sprachlicher Eindeutigkeit." Prechtl, Peter; Burkard, Franz-Peter (Hg.), a.a.O., S. 20.

${ }^{118}$ Vgl. Zima, Peter V., Moderne/Postmoderne: Gesellschaft, Philosophie, Literatur, Tübingen Basel 2001, S. 266.
} 
psychoanalytischen Sinne“119 aufgefasst. Diese Auffassung der Ambivalenz eignet sich m.E. sehr gut dazu, diese als Radikalisierung und Erweiterung der Ambiguität zu begreifen und in dieser Optik den Übergang vom Modernismus (als Spätmoderne) zur Postmoderne zu untersuchen. Bei diesem Übergang diagnostizierte Zima jedoch die allmähliche Ablösung der Ambivalenz-Problematik und zwar von einer Problematik der Indifferenz. ${ }^{120}$

${ }^{119}$ Ebd., S. 303.

${ }^{120}$ Vgl. ebd. S. 301. 


\section{Entropische Desorientierung in Thomas Pynchons The Crying of Lot 49}

\subsection{Einführung}

Thomas Pynchon gehört zu den wichtigsten amerikanischen Nachkriegsautoren und wird den counterrealists ${ }^{121}$ zugerechnet. Er gehört zu den - besonders in den 60er und 70er Jahren populären - Schriftstellern, die das problematische Verhältnis des zeitgenössischen Subjekts zu Symbolen, Zeichen und Pattern, sei es in dem psychologischen, soziologischen oder sprachwissenschaftlichen Bereich, zum Hauptthema seines Werks gemacht haben ${ }^{122}$. Die Vermengung von Erkenntnissen inkompatibler wissenschaftlicher Disziplinen und ihre literarische Bearbeitung ließ Texte entstehen, deren "narrative lines are full of hidden persuaders, hidden dimensions, plots, secret organizations, evil systems, all kinds of conspiracies against spontaneity of consciousness, even cosmic take-over." ${ }^{123}$ Die Werke Pynchons registrieren, nicht zuletzt wegen ihrer enormen Komplexität der miteinander vermengten Ideen und Intuitionen - wie es Heinz Ickstadt treffend zusammenfasst - einen konstanten Abbau intersubjektiver Integrations- und Deutungsmodelle. Im Endeffekt lassen sich in seinen Geschichten kaum Fixpunkte lokalisieren,
„keine privilegierte Position des Überblicks - weder für die handelnden Figuren noch für den Leser, von der aus ein Zusammenhang erkennbar wäre: Pynchons wahrheitssuchende Protagonisten irren in einem Labyrinth nicht auflösbarer Widersprüche und Mehrdeutigkeiten, von endlos ineinander verschachtelten und daher nie abschließbaren Geschichten, aus dem sich nur scheinbar - nur durch die paranoide Setzung eindeutigen Sinns - befreien können.“124

Martin Klepper bemerkt, dass Pynchons Romane auf eine subtilere Art und Weise als die explizite Metafiktion die fundamentale Verunsicherung der Kategorien von Fiktion und

\footnotetext{
${ }^{121}$ Zu den Autoren also, die sich bewusst gegen die Tradition des Realismus und des Naturalismus positioniert haben. Vgl. Peter L. Cooper, Signs and Symptoms, Berkeley, Los Angeles, London 1983, S. 1.

${ }^{122}$ Vgl. Tony Tanner, City of Words. American Fiction 1950-1970, London 1971, S. 15.

${ }^{123}$ Ebd., S. 16.

${ }^{124}$ Heinz Ickstadt, Einleitung, in: Heinz Ickstadt (Hg.), Ordnung und Entropie. Zum Romanwerk von Thomas Pynchon, Reinbek bei Hamburg 1981, S. 10.
} 
Wirklichkeit, Natur und Konvention, Leser und Autor bewirken. ${ }^{125}$ In seinen Texten lassen sich Strategien finden, die langsam und konsequent Analogien zwischen den Situationen seiner Figuren und der Rezeptionssituation der Leser aufbauen. Klepper macht darauf aufmerksam, dass jene Analogien niemals explizit ausgesprochen werden:

„Sie drängen sich umso stärker und eindrücklicher auf, wenn am Ende der Romane die LeserInnen ohne jede Lösung, ja ohne ein auch nur provisorisches Ende der Handlung alleingelassen werden und die jeweiligen Romanwelten genauso rätselhaft in ihrem Bewusstsein zurückbleiben wie es die Erfahrungswelt für Stencil, Oedipa und Slothrop im Laufe des Romans wurde. “126

Seine Schlussfolgerung „,das einheitsstiftende Prinzip für die Sinnkonstitution der LeserInnen wurde vom modernistischen mythischen Subtext, der eine transzendente Lektüre der Wirklichkeit möglich gemacht hatte [...], in die Immanenz der Wahrnehmung der LeserInnen verlegt “ ${ }^{127}$, macht darauf aufmerksam, wie radikal in der Postmoderne die Rolle des Rezipienten des literarischen Textes an Bedeutung gewonnen hat. So gesehen, ist die Lektüre der Romane Pynchons ständig mit der Notwendigkeit verbunden, die an den modernistischen Texten erprobten Deutungsstrategien aufzugeben. ${ }^{128}$ Die Werke Pynchons leben von der Ambivalenz, „especially about detecting and communicating patterns, linking correspondences and making them linguistic, using metaphors to account for a reality that is not directly accessible." ${ }^{129}$ Es ist aber nicht nur Ambivalenz, die das Klima zunehmender Unsicherheit ${ }^{130}$ stiftet und die Lektüre der Werke dieses Schriftstellers zur großen intellektuellen Herausforderung macht. In seinen Romanen jongliert Pynchon mit zahlreichen Termini und Phänomenen unterschiedlicher wissenschaftlicher Disziplinen, indem er seine Plots aus Begrifflichkeiten der Physik, Kybernetik, Soziologie, Psychoanalyse, Religion und Geschichte zusammenbastelt. Eine weitere Schwierigkeit für die Rezeption entspringt der Präsentationsweise dieses Wissens, das weniger informativ, sondern eher kritisch-provokativ

\footnotetext{
${ }^{125}$ Vgl. Martin Klepper, Pynchon, Auster, De Lillo. Die amerikanische Postmoderne zwischen Spiel und Rekonstruktion, Frankfurt/Main New York 1996, S. 99.

${ }^{126}$ Ebd., S. 98. Stencil ist der Protagonist Pynchons ersten Romans V, Oedipa ist die Hauptfigur des von mir untersuchten The Crying of Lot 49, Slothrop ist eine der Figuren im Pynchons bekanntesten Werk Gravity's Rainbow.

${ }^{127}$ Ebd., S. 224.

128 Vgl. Liisa Saariluoma, Der postindividualistische Roman, Würzburg 1994, S. 150.

129 Peter L. Cooper, Signs and Symptoms, Berkeley, Los Angeles, London 1983, S. 204.

${ }^{130}$ Auf die Rolle der Unsicherheit, die die Atmosphäre Pynchons Romane determiniert, haben viele Interpreten hingewiesen. Hier z.B. Cooper: „Uncertainty, for example, is not just a theme: it is also a technique, or rather an ultimate effect that Pynchon achieves through all of his fictional techniques. A favorite stratagem is to build a weird story that strains the reader's 'willing suspension of disbelief', but to build it around a real phenomenon, an actual scientific experiment, or a verifiable bit of history that itself seems weirder than the fiction. As a result, the surreal proves real, and the real becomes surreal." S. 174.
} 
mit den verwirrenden wissenschaftlichen Beziehungen, Regeln und Diskursen, die das Wissen organisieren, spielt. ${ }^{131}$ Eine einleuchtende und zugleich warnende Zusammenfassung der Pynchonschen Schreibweise formulierte treffend Tony Tanner:

„If Pynchons books are confusing, then it is because he is charting and evoking a state of affairs in which authentic inter-subjectivity has all but vanished. He communicates an increasing failure in communication, and is the plotter of a growing disarray. If there is tension and uncertainty in his tone it is because his style is taking issue with the entropy to which it knows it must, like all styles, succumb." 132

Nicht zuletzt wegen ihrer inhaltlichen und formalen Komplexität werden Pynchons Texte von den Literaturwissenschaftlern gern und intensiv untersucht. Eine strikte, im akademischen Kontext betriebene Textanalyse seiner Werke berge in sich jedoch, wie es Richard Poirier behauptet, die Gefahr,

,treating each of the formal or stylistic or allusive elements in a work as a clue to meaning, a point of possible stabilization. This is an especially inappropriate way to treat Pynchon because each of these elements is in itself highly mobile and dramatic. Each is a clue not to meaning so much as to chaos of meaning, an evidence of the impossibility of stabilization."

Der Hinweis Poirers meint zweifelsohne die Notwendigkeit einer besonderen Sensibilisierung während der Konfrontation mit einer Literatur, die programmatisch auf die Desorientierung der Leser zu zielen scheint. Letztendlich mögen es aber eben aufmerksame, interdisziplinär agierende Literaturwissenschaftler sein, die dieses herausfordernde Werk überzeugend zu entschlüsseln vermögen.

Der von mir untersuchte Roman The Crying of Lot $49^{134}$ subvertiert das herkömmliche Schema des Genres des Kriminal- und Spionageromans, indem er „den Handlungsknoten im Verlauf des Romans nicht auflöst, sondern immer weiterknüpft. Jede Entdeckung impliziert eine neue Verwicklung, jede Lösung fordert noch einen nächsten Schritt.“ ${ }^{135}$ CL 49 präsentiert sich als eine Verschachtelung von detektivisch motivierten Ermittlungen, Erinnerungen, Vermutungen, Analogien, Buchstaben- und Wortspielen oder Metaphern. Die Handlung bleibt dabei offen,

\footnotetext{
${ }^{131}$ Vgl. Robert L. McLaughlin, Mediating the Past: Narrative, History, and Teaching Vineland, in: Thomas Schaub (ed.), Approaches to Teaching Pynchon's The Crying of Lot 49 and Other Works, New York 2008, S. 114.

${ }^{132}$ Tony Tanner, a.a.O., S. 180.

${ }^{133}$ Richard Poirier, The Importance of Thomas Pynchon, in: Harold Bloom (ed.), Thomas Pynchon, New York, New Haven, Philadelphia 1986, S. 50.

${ }^{134}$ Weiter zitiert unter Verwendung der Sigle $C L 49$.

${ }^{135}$ Heinz Ickstadt, Thomas Pynchon: Die Versteigerung von No 49, in: Heinz Ickstadt (Hg.), Ordnung und Entropie. Zum Romanwerk von Thomas Pynchon, Reinbek bei Hamburg 1981, S. 111.
} 
„weil sie metaphorische Gleichungen immer weiter ausspinnt und so einen Zusammenhang des Zusammenhanglosen entstehen lässt, der ebenso willkürlich wie bedeutungsschwer - zu einer interpretatorischen Agonie, nicht nur Oedipas [d.i. der Protagonistin - K.S.], sondern auch des Lesers führt.“'136

Die Interpreten Pynchons haben in ihren Analysen von CL 49 unterschiedliche Momente und Textstrategien des Romans hervorgehoben und als zentral für die Konstitution der Bedeutung des Textes bestimmt. Dana Medoro weist z.B. auf die Sprache hin, die in CL 49 „in almost all of its components: comunication, interpretation, sacred and profane signification, silence and noise ${ }^{\text {“137 }}$ untersucht wird, für Hanjo Berressem sind es Beziehungen zwischen der Sprache und der Subjektivität, Peter Freese untersucht insbesondere das Phänomen der Entropie, das im Roman explizit und implizit thematisiert wird und Liisa Saariluoma sieht das Thema des Werkes in der Frage, ,ob die Wirklichkeit mehr anbiete, als das, was auf der Oberfläche erscheine`. Der Roman scheint verschiedene Annäherungsweisen willkommen zu heißen, obwohl es kaum möglich ist, einen „,sophisticated enough theoretical apparatus into which to fit this work ${ }^{\star 138}$, zu finden.

Das Ziel meiner Untersuchung von $C L 49$ ist es, Irritations-, Verwirrungs- und folglich Desorientierungsquellen im Roman zu lokalisieren und ihr Störungspotential für die Konstitution der Bedeutung des gesamten Romantextes zu sondieren. Durch die Skizzierung der Erzählperspektiven möchte ich zunächst die Darstellungsweise des Romangeschehens untersuchen. Des Weiteren wird die geistige Lage der Protagonistin angesichts der Reizüberflutung, die sie im Laufe ihrer detektivischen Ermittlungen erfährt, diagnostiziert und ihr Einfluss auf die Situation des Lesers sondiert. Im letzten Teil wird die Entropie im Roman in ihrer doppelten Funktion analysiert. Die folgende Untersuchung von $C L 49$ sucht zwei Thesen zu begründen: Die Desorientierung darf hier als eine ,entropische' bezeichnet werden, da die erzählte Welt auf eine Art und Weise dargestellt wird, die den Prozess der konsequenten Entdifferenzierung des Geschehenen in Gang setzt, die in den radikalen Zuwachs der ,kommunikativen“ Entropie mündet. Im Gegensatz zu der prozesshaft verlaufenden (auf die Desorientierung zielenden) Entdifferenzierung suchen darüber hinaus Passagen von CL 49 punktuell, einer (Art) Offenbarung und dem Undarstellbaren einen Ausdruck zu geben. Dieses Unterfangen bleibt jedoch erfolglos, denn „unmediated revelation may never appear in a body of language. Yet Pynchon seems to feel that language can suggest

\footnotetext{
${ }^{136}$ Ebd., S. $112 f$.

${ }^{137}$ Dana Medoro, Menstruation and Melancholy: The Crying of Lot 49, in: Niran Abbas (ed.): Thomas Pynchon: Reading from the margins. Madison, NJ 2003, S. 71.

${ }^{138}$ Hanjo Berressem, Pynchon's Poetics Interfacing Theory and Text, Urbana and Chicago 1993, S. 1.
} 
what it cannot present." ${ }^{139}$ Dieses ästhetisch raffiniert inszenierte Suggerieren des momentanen Eindringens einer unbekannten Entität ins Wahrnehmungsfeld der Protagonistin bildet - so meine zweite These - eine weitere, sowohl ontologisch als auch epistemologisch fundierte Verwirrungsquelle in der Darstellung der erzählten Welt von CL 49.

${ }^{139}$ Peter L. Cooper, Signs and Symptoms, Berkeley, Los Angeles London 1983, S. 204. 


\subsection{Orte der Verwirrung}

„Shall I project a world? If not project then at least flash some arrow on the dome to skitter among constellations and trace out your Dragon, Whale, Southern Cross." (CL 49, 56)

An einem Sommernachmittag, nach ihrer Rückkehr nach Hause von einer TupperwareParty, erfährt die Protagonistin Mrs. Oedipa Maas zu ihrer großen Verwunderung, ,that she, Oedipa, had been named executor, or she supposed executrix, of the estate of one Pierce Inverarity, a California real estate mogul [...]“ $(C L 49,5)$ und einst der Liebhaber der Protagonistin. Da sie diese Nachricht zuallererst überwältigt, sagt sie nur laut den Namen Gottes vor sich hin und „tried to feel as drunk as possible.” ( $C L 49,5)$ Verunsichert beginnt Oedipa die Bestandsaufnahme des Vermögens Inveraritys und bald kommen auf sie Verfremdungsgefühle zu, die sie zugleich neugierig und ängstlich machen. Detailreich und präzis schildert der heterodiegetische Erzähler die Lage der Protagonistin dar, sofort verrät er auch, dass er über den Zugang zu ihrem Innenleben verfügt. Die Genauigkeit, mit der er Seite für Seite über Vergangenes und Gegenwärtiges aus dem Leben Oedipas berichtet, muss den Leser bereits nach ein paar Seiten Lektüre dazu bewegen, zu versuchen, sich das Gelesene strategisch zu hierarchisieren und die Relevanz der gelieferten Informationen für die Bedeutungsbildung einschätzen zu können. Die Datenüberflutung könnte aber erst dann eingedämmt werden, wenn man einen Schlüssel entdecken (oder erfinden) würde, der die Unmengen der Details, aus denen das Geschehen von CL 49 zusammengebastelt wurde, in wichtige und redundante Informationen sortieren hülfe. Am Anfang des zweiten Kapitels verspürt Oedipa in einem spontanen Betrachten der monoton wirkenden geometrischen Muster der urbanen Landschaft der Stadt San Narciso, wo Inverarity wohnte und am meisten investierte, ein seltsames Gefühl, das sie an Chiffren verborgener Zusammenhänge und Bedeutungen $^{140}$ denken lässt:

„She drove into San Narciso on a Sunday, in a rented Impala. Nothing was happening. She looked down a slope, needing to squint for the sunlight, on to a vast sprawl of houses which had grown up all together, like a well-tended crop, from the dull brown earth; and she thought of the time she'd opened a transistor radio to replace a battery and seen her first printed circuit. The ordered swirl of houses and streets, from this high angle, sprang at her now with the same

\footnotetext{
${ }^{140}$ Vgl. Heinz Ickstadt, Thomas Pynchon: Die Versteigerung von No 49, in: Heinz Ickstadt (Hg.), Ordnung und Entropie. Zum Romanwerk von Thomas Pynchon, Reinbek bei Hamburg 1981, S. 107.
} 
unexpected, astonishing clarity as the circuit card had. Though she knew even less about radios than about Southern Californians, there were to both outward pattern a hieroglyphic sense of concealed meaning, of an intent to communicate. There`d seemed no limit to what the printed circuit could have told her (if she had tried to find out); so in her first minute of San Narciso, a revelation also trembled just past the threshold of her understanding. Smog hang all around the horizon, the sun on the bright beige countryside was painful; she and the Chevy seemed parked at the centre of an odd, religious instant. As if, on some other frequency, or out of the eye of some whirlwind rotating too slow for her heated skin even to feel the centrifugal coolness of, words were being spoken. She suspected that much." (CL 49, 14f)

Diese Erfahrung wird, wie es sich bald zeigt, den Anfang einer Reihe von Wahrnehmungen markieren, die den bisher schmalen Wahrnehmungshorizont Oedipas sprengen ${ }^{141}$ und die in der Art einer Offenbarung ${ }^{142}$ erscheinen. Der Erzähler scheint eine maximale Nähe zu dem inneren psychologischen Standpunkt der Protagonistin erreichen zu wollen. Nochmals versichert er dadurch den Leser, dass er über die „,volle Introspektion in den inneren Zustand“ “143 Oedipas verfügt und jenen zuverlässig zu erkunden weiß, ohne jedoch „die Selbstwahrnehmung dieser Figur, also die Wahrnehmung der innersten Seelenregungen durch “"144 sie selbst gestalten zu wollen.

Durch diese seltsame Wahrnehmung sensibilisiert, stößt Oedipa bald auf das geheimnisvolle Kryptogramm W.A.S.T.E., das sie an der Toilettenwand und unter Schmierereien an Häusern entdeckt. Allmählich leuchtet ihr ein, dass sie die Spuren einer Untergrundorganisation verfolgt, die, wie sie zunächst glaubt, etwas Gemeinsames mit der Hinterlassenschaft Inveraritys hat. W.A.S.T.E. erweist sich als ein geheimes Kommunikationssystem, als Verschwörung gegen das Kommunikationsmonopol der amerikanischen Post. Von jetzt an häufen sich angebliche Hinweise, Begegnungen mit mutmaßlichen Eingeweihten der Verschwörung, von denen Geschichten voller potentieller Symbole und camouflierter Deutungen erzählt werden. Die Ermittlungen, die Oedipa mit detektivischer Präzision durchführt, führen sie zu einem Punkt, in dem alles, was „she saw, smelled, dreamed, remembered, would somehow come to be woven into The Tristero." (CL 49, 56) Diese seltsame Wahrnehmungsbilanz markiert meines Erachtens den ersten gedanklichen Wendepunkt, Oedipas erste Zweifel an der Verlässlichkeit ihrer Erkenntnis(position). Was sie in dem Moment (noch) nicht begreift, ist die Notwendigkeit des

\footnotetext{
141 „[...] there were revelation in progress all around her." $(C L 49,29)$

142 "Some immediacy was there again, some promise of hierophany: printed circuit, gently curving streets, private access to the water, Book of the Dead..." $(C L 49,20)$

${ }^{143}$ Wolf Schmid, Elemente der Narratologie, Berlin New York 2008, S. 126.

144 Ebd.
} 
Verzichts auf die gewohnte, (privilegierte) Beobachterperspektive, auf die epistemologische Distanz, die eine klare Trennung des Subjekts von dem Objekt zu garantieren scheint. Mit der Frage: „Shall I project a world?” (CL 49, 56) thematisiert die Protagonistin ein Dilemma, dessen Bedeutung sie erst allmählich zu begreifen beginnt. Sie zeigt bereits die volle Bereitschaft, sich der unbekannten Erfahrung öffnen zu wollen, die starre Passivität ihrer geistigen Einstellung hindert jedoch das Betreten der Schwelle zur neuen Erkenntnis(art). Die Anhäufung von Informationen und Spuren, die Oedipa nicht mehr effizient sortieren und deuten vermag, wird allmählich in Verbindung ,mit der Möglichkeit eines anderen Amerika, das sich in den Träumen und apokalyptischen Erwartungen seines menschlichen >Abfalls< konstituiert" ${ }^{\text {145 }}$ gesetzt.

„She had dedicated herself, weeks ago, to making sense of what Inverarity had left behind, never suspecting that the legacy was America. Might Oedipa Maas yet be his heiress; had that been in the will, in code, perhaps without Pierce really knowing [...]” (CL 49, 123) „What was left to inherit? That America coded in Inverarity's testament, whose was that?" $(C L 49,124)$

Dieses Ermittlungsergebnis scheint Oedipa jedoch kaum zu überzeugen, sie will es in der Form nicht wahrnehmen, zunehmend obsessiv angesichts der sie ergreifenden Erschöpfung versucht sie noch klarere, konkretere Möglichkeiten auszusortieren:

„Another mode of meaning behind the obvious, or none. Either Oedipa in the orbiting ecstasy of a true paranoia, or a real Tristero. For there either was some Tristero beyond the appearance of the legacy America, or there was just America and if there was just America then it seemed the only way she could continue, and manage to be at all relevant to it, was an alien, unfurrowed, assumed full circle into some paranoia." (CL 49, 126)

Nochmals weiß der Erzähler die Erkenntnisbilanz der Protagonistin mit perfekter Präzision zu formulieren. Er scheint dadurch Oedipas Bedürfnis, stets Klarheit über den Fortschritt ihrer Ermittlungen vor Augen zu haben, einwandfrei zu realisieren, selbst dann, wenn sich die Klarheit bereits in der genauen Auflistung der Unklarheiten erschöpft. Die Aufstellung der Erkenntnisbilanz der von Oedipa geleisteten Ermittlungen wird zu einem der wichtigsten Knoten in CL 49 und wird nicht nur von dem Erzähler, sondern auch von der Protagonistin reflektiert:

„Either you have stumbled indeed, without the aid of LSD or other indole alkaloids, on to a secret richness and concealed density of dream; on to a network by which $\mathrm{X}$ number of Americans are truly communicating whilst reserving their lies, recitations of routine, arid

\footnotetext{
${ }^{145}$ Heinz Ickstadt, a.a.O., S. 109.
} 
betrayals of spiritual poverty, for the official government delivery system; maybe even on to a real alternative to the exitlessness, to the absence of surprise to life, that harrows the head of everybody American you know, and you too, sweetie. Or you are hallucinating it. Or a plot has been mounted against you, so expensive and elaborate, involving items like the forging of stamps and ancient books, constant surveillance of your movements, planting of post horn images all over San Francisco, bribing of librarians, hiring of professional actors and Pierce Inverarity only knows what-all besides, all financed out of the estate in a way either too secret or too involved for your non-legal mind to know about even though you are co-executor, so labyrinthine that it must have meaning beyond just a practical joke. Or you are fantasying some such plot, in which case you are a nut, Oedipa, out of your skull. Thus, now that she was looking at them, she saw to be the alternatives. Those symmetrical four. She didn't like any of them, but hoped she was mentally ill; that that's all it was." [kursiv - K.S.] (CL 49, 117f)

In dieser längeren Introspektion übernimmt der Erzähler, was in $C L 49$ sehr selten der Fall ist, die perzeptive Perspektive Oedipas. Dieser besondere Moment, in dem die Protagonistin zum „Subjekt [...] der Wahrnehmung [wird], durch die der Erzähler die erzählte Welt entwirft“146, mag den Leser an die Spontaneität ihres Gedankenausdrucks denken lassen. Eine deutlich wenig präzise Konstatierung von Erkenntnisalternativen, die der Perspektive der Heldin zu entnehmen ist, wird vorsichtshalber mit einer Ergänzung seitens des Erzählers abgerundet (s.o. kursiv). Mehrmals muss sich der Leser jedoch im Laufe der Lektüre fragen, welche Textstrategie dafür verantwortlich sei, dass trotz der konstanten und konsequenten Präzision der Darstellung vom Romangeschehen kein Aufklären der anfänglichen Rätsel und kein Fortschritt der Ermittlungen erreicht werden. Worauf zielt dann die - jedem Anschein nach zuverlässige und solide Erzählweise des Erzählers? Brian McHale behauptet, dass ,the reader has no opportunity to view events from outside Oedipa's consciousness, no way to check on her reliability as medium for this story; the reader is bounded by the limits of her mind."147 Es würde also heißen, der Erzähler ziele auf eine möglichst detailreiche Darstellung der Versuche Oedipas, Inveraritys Testament zu vollstrecken, und angesichts des Scheiterns dieser Versuche bemüht er sich um eine möglichst präzise Konstatierung der Endlage der Protagonistin. Die Datenüberflutung, die er dabei herbeiführt, dürfte somit nicht als seine eventuelle Unzuverlässigkeit gedeutet werden, obwohl die Unmengen an Informationen, die seine Erzählung füllen, ein erhebliches Verwirrungspotential anwachsen lassen.

\footnotetext{
${ }^{146}$ Wolf Schmid, a.a.O., S. 136.

${ }^{147}$ Brian McHale, Mc Hale, Brian, Postmodernist Fiction, London and New York 1987, S. 23.
} 
Was darf also der Leser nach der ersten Annäherung an diesen Roman am Ende der Lektüre konstatieren? Wie könnte seine Erkenntnisbilanz aussehen, wie könnte er dem Romangeschehen Bedeutung entnehmen? Hat Oedipa etwa in jeder Hinsicht versagt?

Einerseits verliert sie ,an Erkenntnisgewissheit, was sie an Erkenntnis gewinnt“" 148, andererseits geht sie jedoch aus dem Spiel auf keinen Fall leer aus. Die größte Schwierigkeit (des Lesers) wird meines Erachtens darauf beruhen, den mentalen Gewinn und die Bedeutung ihrer Erkenntnis einschätzen zu können. Erzielt sie etwa ein neues Selbstwissen, gewinnt eine neue Einsicht, schlüpft unter die Oberfläche der rein perzeptiven Erfahrungen durch und sieht sich der bisher ungeahnten Wahrnehmungen gegenüber gestellt, die ihr im Sinne einer Offenbarung eine neue Dimension des Bewusstseins eröffnen? Oder scheitert sie, indem sie genau an der Schwelle innehält, wo sich zwar das Eindringen des Anderen schon verspüren lässt, seine Züge jedoch im Verborgenen bleiben? Die Erkenntnisbilanz, die Oedipa am Ende ihrer Suche ziehen könnte, bezeichnet McHale als

„Teetering on the brink of a miracle, but not the miracle itself; for the novel backs off at the last possible moment from this intrusion of another world, leaving the problem of [...] epistemological skepticism - the problem of solipsism - suspended, finally unresolved."149

In diesem Herauskristallisieren der Alternativen sieht McHale sowohl epistemologische als auch ontologische Motive. Erkenntnistheoretisch gesehen „Oedipa is either deceived or selfdeceived, the victim either of a hoax or of her own paranoia" ${ }^{150}$ In der ontologischen Perspektive gibt es ,ones and zeros. So did the couples arrange themselves. [...] Another mode of meaning behind the obvious, or none. $(C L 49,126)$ Keine der Alternativen scheint plausibler, überzeugender $\mathrm{zu}$ sein, alle Varianten scheinen den gleichen Grad der Wahrscheinlichkeit erreicht zu haben.

\footnotetext{
${ }^{148}$ Heinz Ickstadt, a.a.O., S. 111.

${ }^{149}$ Brian McHale, a.a.O., S. 22.

${ }^{150}$ Ebd., S. 24. Trotz des Signalisierens der ontologisch fundierten Erkenntnisalternativen, sieht McHale in CL 49 einen spätmodernen Roman: „But Oedipa does not break through the closed circle of her solipsism in the pages of this novel; nor does Pynchon break through here to a mode of fiction beyond modernism and its epistemological premises. The Tristero remains only a possibility. [...] The dead ending of epistemology in solipsism can be transcended, but only by shifting from a modernist poetics of epistemology to a postmodernist poetics of ontology, from Oedipas's anguished cry, 'Shall I project a world?', to the unconstrained projection of worlds in the plural." Ebd., S. 24f. Anders als McHale würde ich behaupten, CL 49 hat bereits die Schwelle zum Postmodernen überschritten. Das Eindringen des Anderen scheint in der Sprache nicht ausdrückbar zu sein. Was Pynchon mit allen Mitteln einer raffiniertesten Ästhetik betreibt, ist meines Erachtens die Affirmation von Orten, an denen sich das Undarstellbare offenbaren mag. Dieses Affirmieren führt, wie es scheint, eine neue Entität ein, eine Art ,anwesender Abwesenheit' (Vgl. Zit. 417, S. 117), eine Potenz, die noch keine Form gefunden hat, ein ,excluded middle'. Dieser literarästhetische Kunstgriff führt bereits, meiner Meinung nach, zur Verschiebung der Dominante, da den neuen, d.h. den ontologisch fundierten Phänomenen größere Aufmerksamkeit gewidmet wird.
} 
Diese kurze Skizzierung der Makroebene des Romans, auf der der Leser nach einer sinnhaften Deutung des gesamten Romangeschehens sucht, zeigt bereits die unüberwindbaren Dilemmata, die die Lektüre von $C L 49$ hervorbringen muss. Die Unmöglichkeit, die Bedeutung der Geschichte zu konstituieren, indem alle Ereignisse und Indizien plausibel miteinander verknüpft werden, hat ihren Grund in der Entdifferenzierung der das Geschehen bildenden Elemente, in der Zerstreuung von Daten und Ereignissen, die die Entropie des Textes konsequent steigern. Es ist daher, wie ich des Weiteren zu begründen versuche, der konstante Entropiezuwachs, der die Lektüre zunehmend stören wird. Die Steigerung der Entdifferenzierung wird der Zunahme der Verwirrung an der Seite des Rezipienten entsprechen. Eine Verdichtung von Verwirrungen mündet letztlich in die Desorientierung. Bevor ich jedoch diese am subversivsten wirkende, der den Roman unterlaufendender Kräfte analysiere, möchte ich zunächst die kleineren Irritationen untersuchen, mit denen Pynchon $C L$ 49 ausgeklügelt zu spicken wusste.

Der erste Eindruck der Informationsüberflutung wird bei dem Leser höchstwahrscheinlich mit den ersten Anzeichen der Überforderung seitens Oedipas zusammenlaufen:

„... what she was in for: learn intimately the books and the business, go through probate, collect all debts, inventory the assets, get an appraisal of the estate, decide what to liquidate and what to hold on to, pay off claims, square away taxes, distribute legacies...'Hey,' said Oedipa, 'can’t I get somebody to do it for me?' (CL 49, 12)

Die Protagonistin, die allem Anschein nach keine Erfahrung mit Aufgaben vergleichbarer Komplexität hatte, braucht vor allem eine Strategie des Sortierens, die die Filterung der Reizüberflutung und das Eingrenzen des Wesentlichen ermöglichen könnte. Das ständige Erscheinen neuer Figuren, von denen jede eine unklare Beziehung zu Inverarity und seiner Erbschaft aufweist, verlangt von Oedipa als Testamentsvollstreckerin die Notwendigkeit des Hierarchisierens des erworbenen Wissens und eine Art Sensibilisierung für plötzliche, unerwartete, auf unerklärte Art und Weise mit dem Vermächtnis verbundene, Ahnungen. Trotz der intensivierten Aufmerksamkeit und der Offenheit für die neue Erkenntniserfahrung, vermag sie jedoch nicht, den Sinn aus dem Erlebten herauszudestillieren: „Oedipa painfully discovers that symbols, such as WASTE and its emblem, the muted post horn, do not lead to one stelliferous Meaning. Rather, they point in a thousand different directions and never lead 
to a solid conclusion.“ ${ }^{151}$ Oedipa versucht in Informationen, die ohne Unterbrechung einströmen, Hinweise auf einen eindeutigen Sinn oder Zweck zu entdecken. Ihre Intuition lässt sie von den konkret aufgestellten Aufgaben einer Testamentsvollstreckung absehen und ihre intensivierte Aufmerksamkeit dem Tristero widmen. Ist es dann die Unfähigkeit des Knackens des Codes, die Unmöglichkeit aus den Unmengen des Rauschens die gesuchte Nachricht abzuseihen, die Oedipa daran hindert, Tristeros Form bestimmen zu können? Das Einzige, was Oedipa und somit dem Leser zum Herauspräparieren des Sinns zur Verfügung steht, sind die losen Zeichen und Symbole, durch die sich Tristero zu manifestieren sucht, die Spuren, die das im Geheimen Verborgene an der Oberfläche verstreut. Scheitert Mrs. Maas, weil sie das Geheimcode nicht dechiffrieren kann, so bieten sich für dieses Scheitern zwei Erklärungsmöglichkeiten an: Entweder vermag es Oedipa nicht, „Unterscheidungen außerhalb des Sicherheitsnetzes des vertrauten Codes zu treffen“, und „das Öffnen ihrer Wahrnehmung für die Beschaffenheit einer kontingenten Realität, die offensichtlich viel weiter und komplexer beschaffen ist, als ihre vertrauten kulturellen Pattern“ ${ }^{\star 152}$, bleibt aus. Oder Oedipa hat die Sphäre der Gültigkeit des eigenen Codes bereits verlassen ${ }^{153}$, kann jedoch das neue Territorium nicht betreten, indem sie sich im Rauschen des unbekannten Senders allmählich verliert. Parallel zur wachsenden Unsicherheit der Protagonistin in der Deutung der Zeichen nimmt die Verwirrung des Lesers in den Versuchen der Bedeutungsfindung zu. Zahlreiche Symbole und Anspielungen erweisen sich im Laufe der Lektüre als intertextuelle Sackgassen. Die Informationsüberflutung produziert zahlreiche Irrwege, die jede neu entstandene Deutung mit Skepsis unterlaufen und nicht selten (strategisch) auf Desorientierung zielen:

„Bereits in $V$, wie später auch in Gravity's Rainbow, werden sowohl Charaktere als auch Leser des Romans mit einem ungeordneten Informationsüberangebot konfrontiert, das sie als Ausgangspunkt persönlicher Sinnkonstruktionen überfordert. Der Roman produziert immer mehr Daten, jenseits des Fassungsvermögens irgendeines Systems. “154

\footnotetext{
${ }^{151}$ Anne Mangel, Maxwell's demon, entropy, information: The Crying of Lot 49, in: George Levine, David Leverenz (ed.), Mindful Pleasures Essays on Thomas Pynchon, Boston, Toronto: Little, Brown and Company, 1976, S. 90.

${ }^{152}$ Annibale Picicci, Noise Culture. Kultur und Ästhetik des Rauschens in der Informationsgesellschaft am Beispiel von Thomas Pynchon und Don DeLillo, Berlin 2001, S. 42.

${ }^{153}$ Vgl. ebd., S. 57.

${ }^{154}$ Elisabeth Neureuter, Ordnung und Chaos in amerikanischen Romanen nach 1960. Joseph Heller Catch 22, John Barth Giles Goat-Boy, Thomas Pynchon Gravity's Rainbow, Regensburg 2001, S. 63. Neureuter meint hier vor allem Pynchons größtes Werk Gravity's Rainbow, die Überforderung des Fassungsvermögens des Rezipienten betrifft aber auch CL 49, obwohl in weit niedriger Intensität.
} 
Die Überforderung des Fassungsvermögens dürfte jedoch durch das Umschalten auf ein höheres Niveau, d.h. durch die Erweiterung des Blickwinkels des Lesers bewältigt werden. ${ }^{155}$ Durch die Anwendung der sogenannten kreativen Paranoia könnte der Leser die Kodierung knacken und dadurch einen ,Zugang zu dem Roman finden, indem er eigene Muster ausprobiert und versucht, sich jenseits eines linearen Geschichtsbewusstseins und

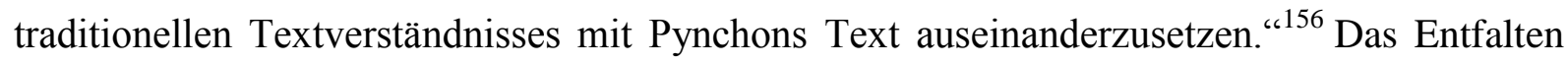
einer kreativen Paranoia, sei es mit dem Ziel der Gewinnung provisorischer Bedeutungen, birgt jedoch in sich die Gefahr der Entstehung weit beliebiger Lesarten und folglich ihrer mangelnden intersubjektiven Nachvollziehbarkeit. Es ist aber nicht klar, was Neureuter mit dem Ausprobieren eigener Muster meint. Sollte es sich dabei um die Freilassung der Fantasie des Lesers bei der Sinnstiftung handeln, so führt dieses paranoiagestützte Lesen schnell zu einem interpretatorischen anything goes.

Die im Laufe der Lektüre entstandene Verwirrung könnte der Leser versuchen zu mildern, indem er auf dem Weg zur Sinnstiftung seine Aufmerksamkeit intensiviert. Bei der Bedeutungskreation will nichts dem Zufall überlassen werden, mühsam knüpft man Verbindungen an allen Stellen. Und am Ende des Romans sieht sich der Rezipient doch mit dem gleichen Dilemma wie Oedipa konfrontiert: „Ist die Welt wahnhaft strukturiert oder ist vielmehr man selber Opfer eines klinisch wahnhaften Wahrnehmungsprozesses?“ 157 Neureuter behauptet, dass das Verständnis von Pynchons Werken nicht mehr auf konventionellem Weg möglich sei, da es zugleich zu viele wie auch zu wenige Zeichen zum Deuten gebe. So gesehen, vermag es der Leser nicht, im Fortschritt der Lektüre eine nachhaltige Interpretation herzustellen: „Es ist eine neue Erfahrung des Lesens, in dem der Leser durch jede neue Wahrnehmung in neue Verwirrung gestürzt werden kann, wobei scheinbare Erleuchtung sich als Vorspiel erneuter Schwierigkeiten erweist.“" ${ }^{\star 158}$

Die Herausforderungen, die die Lektüre von $C L 49$ an ihre Rezipienten stellt, führen zu einer großen Unterschiedlichkeit der Annäherungsversuche an diesen Roman Pynchons. Manche Interpreten starten ihre Analysen bewaffnet mit einem fertigen Instrumentarium, mit einem Begriffsapparat, der die Begrifflichkeit konkreter Theorien oder ihrer Teile liefert. Solche Annäherungsweisen verraten dann auch die Position(ierung) des Interpreten innerhalb der literaturwissenschaftlichen Landschaft. Diese Form der Untersuchung von CL 49 ist jedoch selten anzutreffen. Die meisten ForscherInnen suchen sich in der Konfrontation mit

\footnotetext{
${ }^{155}$ Ebd., S. 91.

$156 \mathrm{Ebd}$

${ }^{157}$ Ebd., S. 92.

${ }^{158}$ Ebd., S. 93.
} 
diesem komplizierten Text Orientierungspunkte und/oder symbolträchtige Motive und Szenen aus und konstruieren Deutungen, indem sie möglichst viele intertextuelle Pfade mit diesen Motiven verlinken. Dietmar Claas markiert z.B. drei grobe Orientierungspunkte in der Unterteilung des Romangeschehens in Vorspiel, visionäres Theater und offenes Finale. ${ }^{159}$ Die Situation der Protagonistin und folglich des Lesers vergleicht er mit einer Verstrickung in risikoreiche Handlungsspiele, die zwischen Spielen und Gespieltwerden oszillieren. Wollen wir mit Claas CL 49 als ein Spiel lesen, so müssten wir am Ende der Lektüre nach den Gewinnern und Verlierern fragen. Claas zählt Oedipa zu den Letzten, da ,je mehr sich die Permutationen des Trystero-Systems an Hand der Informationen, die sie von den einzelnen Figuren erhält, fortsetzen, um so mehr wird sich die Protagonistin ihrer Rolle als Verliererin des Spiels bewusst. Nicht nur, dass sie durch den Informationszufluss betäubt wird, sondern alle Figuren, die in der Rolle ihrer Ratgeber auftreten, werden nach und nach unter grotesk wirkenden Umständen von der Bühne abgezogen $[\ldots]^{\text {‘6160 }}$

Das Bewusstsein, im Spiel als Verliererin zu scheitern, ist ein Effekt eines langen, verwirrenden, komplexen Prozesses, der sich auf den ganzen Roman erstreckt. Noch ein paar Seiten vor dem Ende des Buches konstatiert Oedipa: „so labyrinthine that it must have meaning beyond just a practical joke." (CL 49, 118)

Dieser Ausdruck zunehmender Verzweiflung macht das Spiel jedoch nicht zunichte, die Zweifel lassen die Aufmerksamkeit sich intensivieren, die Suche wird nicht unterbrochen. Und wie verhält es sich mit dem Leser angesichts dieser Schwierigkeiten? Sieht er sich in der gleichen Situation wie Oedipa oder ist seine Lage eine andere? Claas bemerkt, dass der Rezipient aus der Zuschauerrolle herausgenommen werde und dabei seine gewohnte privilegierte Distanz verliere. ${ }^{161}$ Wie ist es aber zu verstehen? Verantwortlich für die Lage des Rezipienten sei natürlich der Erzähler; in unserem Beispiel wird sich seine angebliche Allwissenheit als enttäuschend und nutzlos erweisen, da er trotz der übertriebenen Detailliertheit und Präzision seines Berichts nichts Erklärendes und Hinweisendes im Hinblick auf das Auflösen der Rätsel des Inverarity-Vermächtnisses beisteuert. Durch die Enttäuschung dieser Erwartungen wird dem Leser allmählich klar, dass die perzeptive

\footnotetext{
${ }^{159} \mathrm{Vgl}$. Dietmar Claas, Ein abgekartetes Spiel? Handlungsspiele in Die Versteigerung von No. 49 und die innovative Leistung des Lesers, in: Heinz Ickstadt (Hg.), Ordnung und Entropie. Zum Romanwerk von Thomas Pynchon, Reinbek bei Hamburg 1981, S. 132. Dazu kommt noch das Spiel im Spiel - „The Courier's Tragedy“ von einem fingierten Autor - Richard Wharfinger -, das „den Plot der nachelisabethanischen Rachentragödie mit deutlicher Überzeichnung des ganzen Ausmaßes an Grausamkeit, Sex und Intrigen“ parodiert und eine zusätzliche Verwirrung auf dem Weg zum Enthüllen des Tristero stiftet. Ebd.

${ }^{160}$ Ebd., S. 135.

${ }^{161}$ Vgl. ebd., S. 136.
} 
Perspektive des Erzählers so gut wie die der Protagonistin fungieren könnte. Die Verwirrungen Oedipas werden somit zu den Verwirrungen des Lesers.

Eine originelle Erkundung der Irrwege, auf die die Rezeption von $C L 49$ führt, liefert Hanjo Berressem. Seine im Geist des Poststrukturalismus durchgeführte Untersuchung hilft meines Erachtens das Desorientierungspotential dieses Romans ein wenig zu belichten. Berressem deutet die erzählte Welt von $C L 49$ als ein ,cybernetic wasteland' und macht sich auf den Weg zur Erkenntnis „of the gradual decomposition of this cybernetic space - a process that entails the dissemination of its inhabitants - as well as the multiple entropies at work in it.“162 Die Radikalität, mit der sich der Roman gegen interpretative Schemata wehrt, verlangt nach Berressem eine entsprechende Radikalität auf Seiten des Lesers. Der Text, in dem ,several frames of reference constantly overlap, invites ontological, epistemological and sociocultural readings equally. Rather than focus on one specific angle, [sollte $C L 49$ ] as a textual site on which various reading intersect"163 untersucht werden.

Eines der wichtigsten Phänomene, das auf verschiedenste Art und Weise im Roman zum Ausdruck kommt, ist die Kommunikation. Bei keinem der postmodernen Autoren ist die intermediale Dimension des Kommunizierens so stark ausgeprägt wie bei Pynchon. In einer chaotischen Verschachtelung von verschiedensten Medien, wie Radio, Fernsehen, Telefon, Briefe, Bücher und Schrift im Allgemeinen ${ }^{164}$ scheint er einerseits die neugeborene Multimedialität zu affirmieren, andererseits macht er aber auf mögliche Risiken und mentale Peripetien aufmerksam, die die neue Kommunikationsära mit sich bringt.

Die Wandlung von einer industriellen zu einer postindustriell-kybernetischen Gesellschaft impliziert nach Baudrillard eine Wandlung von allienation zur ecstacy of communication. ${ }^{165}$ In einer Gesellschaft solcher Art werden Medien zu den Trägern der Simulation, erobern immer weitere Bereiche des Realen und bilden da Orte, an denen die Wirklichkeit in die Simulation transformiert wird. Die Idee der Simulation, so wie sie Baudrillard erfasst, scheint nach Berressem zutreffend einen der Orte des Geschehens im Roman - die Stadt San Narcisso - zu beschreiben: „Pynchon`s fictional city is, [...] a town, whose mystery is precisely that it is nothing more than a network of endless, unreal circulation.“166 Solche Stadt verliert alle

\footnotetext{
162 Hanjo Berressem, Pynchon's Poetics Interfacing Theory and Text, Urbana and Chicago 1993, S. 83.

163 Ebd.

${ }^{164}$ Vgl. Hubert Zapf, Postmoderne Literaturtheorie, in: Hans Vilmar Geppert, Hubert Zapf (Hg.), Theorien der Literatur Grundlagen und Prinzipien, Bd. 2, Tübingen 2005, S. 218.

${ }^{165} \mathrm{Vgl}$. Hanjo Berressem, a.a.O., S. 84.

${ }^{166}$ Ebd., S. 86.
} 
ihre einst typischen Funktionen und wird zu einem Bereich ,of the execution of the sign": „San Narcisso is in the first instance just such a complex agglomeration of multiple networks of sign systems, whose interweaving results in a complicated grid of superimposed levels of reality. “ ${ }^{167}$ In dieser Optik lassen sich auch - meines Erachtens einleuchtend - mehrere verwirrende Momente des Romangeschehens untersuchen. Dies zeigt Berressem am Beispiel des letzten Telefongesprächs Oedipas mit Inverarity, an das sie sich angesichts der Aufforderung zur Vollstreckung seines Testaments erinnert:

„[...] last year at three or so one morning there had come this long-distance call, from where she would never know (unless now he'd left a diary) by a voice beginning in heavy Slavic tones as second secretary at the Transylvanian Consulate, looking for an escaped bat; modulated to comic-Negro, then on into hostile Pachuco dialect, full of chingas and maricones; then a Gestapo officer asking her in shrieks did she have relatives in Germany and finally his Lamont Cranston voice, the one he'd talked in all the way to Mazatlan. 'Pierce, please', she'd managed to get in, 'I thought we had - 'But Margo,' earnestly, 'I've just come from Commissioner Weston, and that old man in the fun house was murdered by the same blowgun that killed Professor Quackenbush,' or something. 'For God's sake,' she said. Mucho had rolled over and was looking at her. 'Why don't you hang up on him,' Mucho suggested sensibly. 'I heard that,' Pierce said. 'I think it's time Wendell Maas had a little visit from The Shadow.' Silence, positive and thorough, fell. So it was the last of his voices she ever heard. Lamont Cranston. That phone line could have pointed any direction, been any length. Its quiet ambiguity shifted over, in the months after the call, to what had been revive $[\ldots](C L 49,6)$

Was sich aus diesem seltsamen Gespräch gut herauskristallisieren lässt, ist nach Berressem eine Art Definition Inveraritys, ,as a mere compound and reflection of various cultural icons and a switchboard of various discursive frameworks. His constant shifting of voices hides a more basic void and exposes his personality as being always already an impersonation."168 Berressem sieht bereits hier die ersten Anzeichen dafür, dass Oedipas Aufgabe zum Scheitern verurteilt war, denn „Pierce is not an original person but a cultural simulacrum, an extension of culture." 169 Einen ähnlichen ontologischen Status schreibt Berressem auch der Protagonistin zu: „Oedipa herself is the result of a similar inscription into and encoding by culture." ${ }^{170}$ Solcher Status von Oedipas Ego wird ihre gesamte Position und die Grenzen ihrer

\footnotetext{
${ }^{167}$ Ebd.

168 Ebd., S. 89

169 Ebd.

170 Ebd.
} 
Erkenntnis gravierend beeinflussen. ${ }^{171}$ Das Vermengen von inkompatiblen ontischen Ordnungen einerseits und ihr Sich-Ergänzen andererseits, ähnlich wie es bei dem Simulierten und dem Realen der Fall ist, bildet meines Erachtens eine der wichtigsten Verwirrungsquellen in $C L$ 49. Im Roman werden nicht nur menschliche Stimmen simuliert, sondern auch ein physikalisches Phänomen und die Verzerrung der Rundfunkübertragung. Was den Leser dabei verwirren muss, ist die fehlende Funktion, die diese Simulationen erfüllen sollen. Sie funktionieren im Roman nicht als alternative Dimensionen, sie scheinen lediglich dem Realen seine Intensität abzunehmen.

Das Nebeneinander-Existieren von simulierten und realen Erscheinungen führt Peripetien im Wahrnehmungsfeld herbei, da es nicht immer möglich ist, die Grenze zwischen ihnen zu ziehen. Eine wichtige Rolle spielen dabei, worauf Zofia Kolbuszewska aufmerksam macht, die räumlichen Beziehungen in $C L$ 49. Eine spezifische Spannung zwischen der Offenheit und der Geschlossenheit, die die Protagonistin und somit die Leser während der Lektüre begleitet, wird nach Kolbuszewska zur häufigen Ursache interpretatorischer Schwierigkeiten ${ }^{172}$ : „The mysterious outside is mapped onto the closed, familiar space. The conflation of two opposites constitutes the frame of Oedipa's quest. “173 In ihrer Untersuchung betont Kolbuszewska die Rolle der Wörter wie ,Brücke‘ oder ,Fenster ${ }^{174}$, die die räumlichen Zusammenhänge bestimmen und problematisieren. ${ }^{175}$ Als ,Brücke‘ bezeichnet sein Projekt Oedipas Psychoanalytiker Dr. Hilarius. Es handelte sich dabei um das Experimentieren mit Drogen, die den Hausfrauen bürgerlicher Herkunft verabreicht werden sollten: „A spatial term [d.i. Brücke - K.S.] is thus used in connection with the relationship of the human psyche, or the mind, an external reality."176

Das Kommunizieren mit dem Outside, das in CL 49 mehrmals inszeniert wird, trägt zunehmend gefährliche und zugleich wahnhafte Züge. Der alte Seemann ist im Roman einer

\footnotetext{
${ }^{171}$ Ebd., S. 92 „Because the ego is not a prereflexive, originary entity but rather the result of an inscription into cultural space, her perceptions are her own only to the extent to which they are ultimately not her own. Like Pierce, she herself is a merely accidental cultural crossroad [...]" In seiner Untersuchung analysiert Berressem das Ego der Protagonistin im Kontext der Lacanschen Psychoanalyse, was einerseits sehr originelle, andererseits aber sehr verworrene Ausführungen liefert.

${ }^{172}$ Zofia Kolbuszewska, The poetics of chronotope in the novels of Thomas Pynchon. Lublin 2000, S. 81 „The narration begins in the closed, familiar space of the protagonist's apartment and stops short of the awaited revelation in the equally closed space of an auction hall. Nevertheless, each time the openness of the alien, unfamiliar Other hovers in the background."

${ }^{173}$ Ebd.

${ }^{174}$ „A distant view of metaphysical space can be glimpsed only by means of a metaphor; a metaphor whose vehicle employs elements of physical space - windows." Ebd., S. 83.

${ }^{175}$ Kolbuszewska macht darauf aufmerksam, dass der Raum des Anderen konsequente Nähe zum physischen Raum aufweist. Die Natur von Oedipas Suche nach dem Tristero könnte daher als ein Treffen physischer und metaphysischer Dimensionen konzeptualisiert werden. Vgl. Ebd., S. 83.

${ }^{176}$ Ebd., S. 82.
} 
der Charaktere, der diese geheime nicht-diskursive Kommunikation am eigenen Geist erfahren konnte. Konkreteres über diese Erfahrungen wird nicht preisgegeben, der mentale Zustand des Mannes zeigt aber Spuren von traumaähnlichen Erlebnissen, Oedipas Treffen mit ihm bringt sie jedoch (erkenntnismäßig) nicht weiter:

„She knew, because she had held him, that he suffered DTs. Behind the initials was a metaphor, a delirium tremens, a trembling unfurrowing of the mind's ploughshare. The saint whose water can light lamps, the clairvoyant whose lapse in recall is the breath of God, the true paranoid for whom all is organized in spheres joyful or threatening about the central pulse of himself, the dreamer whose puns probe ancient foetid shafts and tunnels of truth all act in the same special relevance to the word, or whatever it is the word is there, buffering, to protect us from. The act of metaphor then was a thrust at truth a lie, depending where you were: inside, safe, or outside, lost. Oedipa did not know where she was.“ (CL 49, 88f)

Die Metaphorik, mit der der Erzähler das Treffen der Protagonistin mit dem Seemann darstellt, verdunkelt meines Erachtens jede mögliche Rechtfertigung dieser Begegnung. Kolbuszewska sieht hier einen Hinweis, indem der Erzähler auf die schützende Funktion des ,Wortes' aufmerksam macht. Selbst ,Wort‘ wird räumlich wahrgenommen, wie sie bemerkt, und zwar als ein schützender Puffer, da es nur innerhalb eines sozialen Diskurses eine relative Sicherheit geben kann und ,indirect contact with the Other, disastrous for the member of the semiotic community, is available only to those who are delirious. “ ${ }^{\text {177 }}$ Die Warnung ,the only way the space of the Other can come in contact with the physical space or the space of social reality is by violence ${ }^{\text {‘178 }}$, hört Oedipa nicht nur einmal. Ein mexikanischer Anarchist, Jesus Arrabal, versuchte sie bereits früher für diese Art Erfahrung sensibilisieren: „You know what a miracle is [...] another world's intrusion into this one. Most of the time we coexist peacefully, but when we do touch there's cataclysm.“ (CL 49, 83) Das wiederholte Suggerieren des ,Eindringens einer anderen Welt ${ }^{\star}$, das mit zunehmender Aufdringlichkeit und in Form von verwirrender Metaphorik von dem Erzähler betrieben wird, muss den Leser angesichts einer Reihe der nicht gehaltenen Versprechen zur völligen Verzweiflung bringen, einer Verzweiflung, die aus dem Bewusstsein der Nutzlosigkeit aller Sinnbildungsversuche resultiert.

Das Agieren der Figuren in Pynchons Romanen lässt sich auch, wie es Gabriele Schwab tut, im Kontext eines spezifischen Spannungsverhältnisses zwischen der transpersonellen, von den Institutionen geprägten Ebene und der individuellen, vom Alltagsbewusstsein der Figuren

\footnotetext{
${ }^{177}$ Ebd., S. 35.

${ }^{178}$ Ebd., S. 34.
} 
geprägten Ebene situieren. Diese Spannung bestimmt dabei einerseits den Status der Entropie im Text, andererseits ist sie für Pynchons Geschichtskonzeption fundierend. ${ }^{179}$ Die Geschichte wird nach Schwab

„weder auf der einen noch auf der anderen Ebene gemacht, sondern aus einem komplexen Zusammenspiel beider, das für die Figuren indessen nicht mehr überschaubar ist. Dies wird noch dadurch kompliziert, dass auch neue, im Entstehen begriffene Ordnungen nicht unmittelbar als solche erfahren werden können.““180

Eine bestimmte Systemüberkomplexität lässt sich nur dann verarbeiten, wenn das Subjekt dazu fähig ist, seine eigenen Erfahrungen zu differenzieren. „Die Spannung zwischen Alltagsbewusstsein und theoretisch bereits antizipierbaren höherdifferenzierten Bewusstseinsformen [...] ${ }^{181}$ könnte man daher als strukturbildend auch in CL 49 untersuchen. Pynchons komplexe und verworrene Ordnungsmuster scheinen auch hier über die vertrauten Ordnungsachsen von Raum, Zeit und Kausalität hinauszuweisen. Was der Erzähler dabei auszudrücken sucht, sei die Simulation einer vierdimensionalen Perspektive und die Ansiedlung des Textes auf der Grenzfläche zwischen drei- und vierdimensionalem Denken. ${ }^{182}$ Dieser Vierdimensionalität liege folgende Konzeption zugrunde:

In his books, the time-bound world of the senses is suffused with the four-dimensional world of the space-time continuum. The four-dimensional world is used by Pynchon as the scientific expression of continuity unavailable to us on 'this side', and is a figure for the continuities of timeless meaning and connection which exist at once with the historical time his characters and readers experience. This 'beyond' is invoke not as indication of an alternative reality permitting escape from our condition, but as part of Pynchon's project to establish the poise between fragmentary experience and continuous meaning. Such continuity is never a release from doubt but is an intensifying of the importance of that uncertainty." 183

Pynchons Figuren leben somit in einer dreidimensionalen Welt, kreieren jedoch mentale Konstruktionen, die eine weitere Dimension eröffnen. Beide Welten seien nach Schaub real, „but one is experienced while the other [...] is an abstraction that subsumes the three-

\footnotetext{
${ }^{179}$ Vgl. Gabriele Schwab, Entgrenzungen und Entgrenzungsmythen: zur Subjektivität im modernen Roman; Daniel Defoe, Herman Melville, Virginia Woolf, James Joyce, Samuel Beckett, Thomas Pynchon, Stuttgart 1987, S. 187.

${ }^{180}$ Ebd., S. 187.

181 „,...] wirkt strukturbildend in Gravity's Rainbow“. Schwab untersucht den größten Roman Pynchons Gravity's Rainbow. Viele ihrer Ausführungen scheinen aber auch Probleme in CL 49 treffend zu beschreiben. Ebd., S. 187.

${ }^{182}$ Vgl. ebd., S. $187 f$.

183 Thomas Schaub, Pynchon: the voice of ambiguity, Urbana 1981, S. 4.
} 
dimensional world without abridging its laws for those within it." ${ }^{\text {"184 }}$ Pynchons Charaktere würden in dieser Optik an der Schnittstelle zwischen den Fakten (geäußerten im gedruckten Wort) und dem, was für Bedeutung diese Fakten haben könnten, existieren. Die Bedeutung ist bei Pynchon jedoch immer das Medium, „not an answer; his goal is to induce that medium, verging on psychosis, whereby the sterile and false world of 'offical' forms is given the lie by a protective and inquisitive alertness, leaving an uncertain reality which both terrifies and releases." ${ }^{185}$ Oedipa beginnt der sich der Worten entziehenden Bedeutung eine religiöse Dimension zuzuschreiben, indem sie sich ,parked at the centre of an odd, religious instant“ $(C L 49,15)$ fühlt. Anders gesagt, „Oedipa tends to see not only designs but also a design in the designs, a 'meaning' that is paradoxically 'concealed' and yet 'intended' to communicate something." 186 Cooper bemerkt, dass diese mentale Einstellung (habit of mind) der Protagonistin viel früher als ihre Entdeckung des Tristero erweckt wurde:

\begin{abstract}
„The downhill view of San Narciso ${ }^{187}$ and the map of the Fangoso Lagoons ${ }^{188}$ promise her 'hierophany ${ }^{6189}$ at the beginning of her adventure, introducing her to the idea of some hidden, integrating order of Meaning; but when she descends from the overview of the mountain or the blueprint into the grotesque jumble of immediate events, she senses only hieroglyphic objects no patterns - which she then tries to synthesize into a coherent picture, perhaps driven by the gap between the possibility of order and the actuality of chaos." ${ }^{190}$
\end{abstract}

\footnotetext{
184 Ebd., S. 9.

185 Ebd., S. 104.

${ }^{186}$ Peter L. Cooper, Signs and Symptoms, Berkeley, Los Angeles, London 1983, S. 144.

${ }^{187}$ S.o., S. $6 f$.

188 „On came a loud commercial for Fangoso Lagoons, a new housing development west of here. 'One of Inverarity's interests,' Metzger noted. It was to be laced by canals with private landings for power boats, a floating social hall in the middle of an artificial lake, at the bottom of which lay restored galleons, imported from the Bahamas; Atlantean fragments of columns and friezes from the Canaries; real human skeletons from Italy; giant clamshells from Indonesia - all for the entertainment of Scuba enthusiasts. A map of the place flashed on to the screen, Oedipa drew a sharp breath, Metzger on the chance it might be for him looked over. But she'd only been reminded of her look downhill this noontime. Some immediacy was there again, some promise of hierophany: printed circuit, gently curving streets, private access tot he water, Book of the Dead... (CL 49, 19f)

189 "It is impossible to overemphasize the paradox represented of every hierophany [...] By manifesting the sacred, any object becomes something else, yet it continues to remain itself." Mircea Eliade, The Sacred and the Profane: the Nature of Religion, New York 1961. (zit. nach Thomas Schaub Pynchon: the voice of ambiguity, Urbana 1981, S. 108.)

${ }^{190}$ Cooper, a.a. O., S. 144.
} 
Die Hierophanien, die Oedipa heimsuchen, kommen immer in Form von unconnected flashes. Diese Annäherungen an diese weihevollen Erkenntnisse bleiben jedoch nichts mehr als nur Annäherungen. ${ }^{191}$ Sie intensivieren jedoch die Atmosphäre der Erwartung. Und der Leser „like Oedipa, [...] encounters 'a secret richness and concealed density of dream' but nothing much more concrete and verifiable. Consequently, one may begin to suspect that the miraculous intrusion and otherworldly communications are unreal. Even if the clues do proceed to revelation, this Pentecostal moment may be impossible to hold. In this way, Oedipa, or anyone hovering at the threshold of such knowledge, is totally adrift, without compass or quadrant." 192

Diese besonderen Inszenierungen sich nähernden Offenbarungen, „this stylistic tension that positions characters and reader alike at the interface between opposite views of the same event"193, werden zur Strategie der Verwirrung, die das ganze Romangeschehen konsequent unterlaufen. Man könnte sogar die These riskieren, dass fast jede neu eingeführte Figur genau an dem Punkt verschwindet, an dem sie zu einer sinnhaften Verknüpfung der losen Indizien hinführen könnte, dass fast jede neu wahrgenommene Information genau in dem Moment unterbrochen wird, in dem sie den roten Faden des Geheimnisses Inveraritys enthüllen würde. Angesichts solcher Dialektik der leeren Hierophanien erschöpft sich die Rezeption von CL 49 in der Bildung der kleinen Inseln des Sinns, in der allmählich anwachsenden Kollektion von Mikrobedeutungen, die gegen jeden Verknüpfungsversuch resistent bleiben.

Das Treiben dieses raffinierten Versteckspiels mit Offenbarungen weiß Pynchon mit Metaphorik zu schmücken, die alles andere als Sinnversprechen erwarten lässt: „Pynchon’s narratives purposely avoid completing the metaphoric act because he is after the intimation of meaning not its dogmatic assertion. He wants to create suspicion and paranoia, not confident conviction and belief." 194 Die Intention Pynchons sei jedoch nicht, wie es Schaub einleuchtend betont, ,a denial of the possibility of meaning, or of the connections between experience and meaning, so much as it is an insistence that meaningfulness requires uncertainty." 195 Eine eindeutige Darstellung von Oedipas Erfahrungen als mystisch oder religiös würde die Qualität ihrer Queste sicherlich verändern und die Rolle ihrer Wahrnehmungen weit verringern: „Such an affirmation would mean only that she had found a secret enclave, instead of an exact and rigorous relationship between her culture and her

\footnotetext{
191 „In pursuing hierophany, Oedipa remains something of a novice; she speaks of projecting worlds and tracing constellations, but [...]she never takes her thinking a step further to discuss the methodology or the moral and philosophical justification of such activity. Ebd., S. 170.

192 Ebd., S. 151.

${ }^{193}$ Thomas Schaub, Pynchon: the voice of ambiguity, Urbana 1981, S. 105.

194 Ebd., S. $106 f$.

${ }^{195}$ Ebd., S. 107.
} 
understanding of it. This relationship is rigorous because it encompasses opposites which refuse to resolve." 196

Die enttäuschende Erfahrung, das Metaphernspiel in $C L 49$ als eine interpretatorische Sackgasse erklären zu müssen, wird der verwirrte Leser meines Erachtens schnellstmöglich kompensieren wollen. Als besonders auffallend werden ihm wahrscheinlich die - ab und zu erscheinenden - Buchstaben- und Anagrammspiele erscheinen, die erneut als Versprechen versteckter Bedeutung fungieren werden. Das beste Beispiel liefert hier der Rufname Muchos (d.i. des Mannes Oedipas) Rundfunksenders - KCUF. Möchte man den Namen als ein Anagramm deuten, so wird er höchstens zu einem Witz. Schaub behauptet jedoch, dass er einen Teil Pynchons Strategie bilde, die zum Ziel habe, beim Leser den Zustand der sich intensivierender Wachsamkeit aufrechtzuerhalten, die der gedeihenden Paranoia auf Seiten Oedipas entsprechen sollte:

„The call letters present the reader with a set of questions which parallel those facing Oedipa: are these letters arbitrary or purposeful? Have they a literal meaning directly linked to specific plot and character, or are they relevant only within the complex of meaning of the book? The letters are never questioned within the novel. [...] but their primary purpose is to call attention to themselves and raise the possibility that the text itself may be only a tasteless joke or a code promising a meaningful world." 197

Die Aufgabe der durchgeführten Erkundung war es, die ersten Momente und Textstrategien zu bestimmen, die den Prozess der Bedeutungsbildung während der Lektüre von $C L 49$ beeinträchtigen und für die zunehmende Verwirrung des Romanrezipienten sorgen können. Was zunächst potenzial irritierend wirken kann, ist meines Erachtens nicht so sehr die Zuverlässigkeit des Erzählerberichts, sondern die Menge an Informationen, die die erzählte Welt konstruiert. Eine höchst detaillierte Darstellung wird wahrscheinlich schnell das Gedächtnisvermögen des Lesers überfluten und lässt ihn dadurch sich darum Sorgen machen, ob er die Relevanz der stets einströmenden Daten richtig einschätzen kann. Die erste Enttäuschung seitens des Rezipienten würde spätestens dann wahrgenommen werden, wenn er begreift, dass er im Text keine Hinweise findet, die den Informationsstrom vernünftig sortieren und hierarchisieren ließen. Eine tiefere Verwirrung würde ich den wiederholt inszenierten ,Hierophanien“ zuschreiben, die jedes Mal die Aufmerksamkeit des Lesers mit dem Versprechen einer versteckten Bedeutung locken, um diese dann jeweils zu enttäuschen.

\footnotetext{
196 Ebd.

${ }^{197}$ Ebd., S. 113.
} 
Die ästhetisch raffiniert konstruierte Näherung der Offenbarrung wird kompliziert durch den Einsatz verworrener und geheimnisvoller Metaphorik, die als nicht genug sinnträchtig erscheinen kann, um mit dem weiteren Geschehen logisch verknüpft werden zu können.

Im Folgenden wird das allmähliche Sich-Verlieren Oedipas in den Versuchen der Testamentsvollstreckung untersucht. Analysiert werden die Erkenntnisstrategien, die sie zu entfalten sucht, um angesichts der Unmöglichkeit, die Bedeutung des Inverarity-Legats zu begreifen, dem Wahrgenommenen - selbst um den Preis der Paranoia - Sinn zu verleihen. 


\title{
3.3. Tristero und der Weg zur Paranoia
}

\begin{abstract}
„Es ist paranoid, einen Zusammenhang zwischen den von Inverarity produzierten Knochenpulverfiltern und dem Stück Wharfingers zu sehen, und paranoid ist es auch sich in das Experimentieren mit der Nefastis - Maschine einzulassen, weil die Person, die ihr davon erzählt, WASTE - Zeichen vor sich hinkritzelt. [...] Daß hinter Inveraritys Erbschaft eine geheime Gesellschaft entdeckt wird, die nicht einmal etwas mit dieser Erbschaft zu tun hat, weist auch auf Paranoia hin.“
\end{abstract}

Liisa Saariluoma

Tristero scheint das ungewisse Etwas zu sein, das allem Anschein nach den wichtigsten Bedeutungsknoten des Romans bildet, ein Name, dessen Denotat so lange und so konsequent der Bestimmung entzogen wird, dass sein mühsames Aufspüren-Wollen in die Paranoia mündet. Tristero wird recht spät in die erzählte Welt eingeführt, es erscheint zum ersten Mal am Anfang des dritten Kapitels, auf Seite $29^{198}$ :

„If one object behind her discovery of what she was to label the Tristero System or often only The Tristero (as if it might be something's secret title) were to bring to an end her incapsulation in her tower, then that night's infidelity with Metzger would logically be the starting point for it; logically. That's what would come to haunt her most, perhaps: the way it fitted, logically, together.“ (CL 49, 29)

Seltsam muss es dem Leser erscheinen, dass da auf einmal die Rede von einer Entdeckung ist, die er bislang nicht wahrnehmen konnte. Das Einzige, was die Wachsamkeit bisher wirklich anlockte und intensiviert hatte, waren Oedipas Hierophanien, diese Zustände der neuen Hellhörigkeit, die jedoch nicht einmal die geringste Spur der Existenz eines geheimen Systems verrieten. Ein wenig später scheinen sich Oedipas Vermutungen zu bestätigen, indem sie an der Klowand in der Bar Scope, die sich als der Hauptreff der Elektroniker von Yoyodyne erwies, eine in Druckbuchstaben geschriebene Botschaft entdeckt:

„Interested in sophisticated fun? You, hubby, girlfriends. The more the merrier. Get in touch with Kirby, through WASTE only, Box 7391, L.A. WASTE? Oedipa wondered. Beneath the notice, faintly in pencil, was a symbol she'd never seen before, a loop, triangle and trapezoid, thus:

\footnotetext{
198 In der Ausgabe, die 127 Seiten zählt.
} 


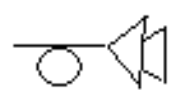

It might be something sexual, but she somehow doubted it. She found a pen in her purse and copied the address and symbol in her memo book, thinking: God, hieroglyphics.“ $(C L 49,34)$

Die komische Entdeckung an der Toilettenwand und das Treffen in der Bar mit Mike Fallopian, der Oedipa und Metzger die Existenz eines geheimen Verteilernetzes verrät, versichert die Protagonistin, dass „for Oedipa, the languid, sinister blooming of The Tristero“ (CL 49, 36) beginnt:

„Or rather, her attendance at some unique performance, prolonged as if it were the last of the night, something a little extra for whoever'd stayed this late. [...]; as if a plunge towards down indefinite black house long would indeed be necessary before The Tristero could be revealed in ist terrible nakedness.“ $(C L 49,36)$

Woher kommt aber die unheimliche Stimmung, die Oedipa dem Tristero zuschreibt? Ist es vielleicht bloß die Intuition der Protagonistin, die eine bedrohliche Aura vorwegnimmt? Die sich ab jetzt häufenden Verbalisierungen des Tristero verdichten jedoch neue Verwirrungen. Die furchterregende Atmosphäre ähnelt der des Stücks The Courier's Tragedy, auf das Oedipa aufmerksam gemacht wird. Fast am Ende dieses blutigen Spiels voller Morde und Massaker fällt das geheime Wort wieder: „Tristero. The word hung in the air as an act ended and all lights were for a moment cut; hung in the dark to puzzle Oedipa Maas, but not yet to exert the power over her it was to." $(C L 49,51)$ Der letzte Satz darf meines Erachtens als ein wichtiger Hinweis gedeutet werden. Der höfliche Erzähler sucht die mögliche Verwirrung zu mildern, indem er dem Rezipienten einen informationellen Vorsprung der Protagonistin gegenüber erteilt. Dass sich dieses Privileg als nutzlos erweist, bekommt der Leser enttäuschend $\mathrm{zu}$ spüren, indem seine Wachsamkeit mit keinerlei Verwirklichung des Sinnversprechens belohnt wird. Ohne einen Durchbruch in der Suche nach dem Geheimen erlebt zu haben, muss Oedipa - ungefähr in der Hälfte des Roman(geschehen)s - feststellen, dass ,everything she saw, smelled, dreamed, remembered, would somehow come to be woven into The Tristero.“ (CL 49, 56) In diesem Moment entdeckt sie einen ihr bisher unbekannten Erkenntnisweg, der ihre Aufgabe nicht mehr (nur) als ein Enthüllen des Verborgenen, sondern als eine ,Projektion“ ${ }^{199}$ neu definieren sollte. Das explizite Thematisieren dieser

\footnotetext{
199 "Soll ich eine Welt projizieren?" "Shall I project a world?” $(C L 49,56)$ Dieser bereits von mir zitierte Satz wird von den meisten Interpreten als eine der wichtigsten Äußerungen der Protagonistin beurteilt. Unterschiedlich sind jedoch die Einschätzungen, ob diese Frage den Durchbruch in der epistemologischen Einstellung Oedipas
} 
Erkenntnisalternative könnte auch im Kontext des Sensibilisierungsprozesses Oedipas situiert werden, der sie für die kryptischen Zeichen des Tristero empfänglich machen sollte. ${ }^{200}$ Dank der neuen Einsicht wird Oedipa ihre mentalen Kräfte erneut mobilisieren. Sie intensiviert ihre Suche, prüft die Herkunft des Wortes Tristero in anderen Ausgaben des Spiels The Courier's Tragedy, trifft seltsame Menschen, die entweder Pierce Inverarity kannten oder etwas Gemeinsames mit seinem Erbe haben könnten, nimmt Inveraritys Briefmarkensammlung unter die Lupe und besucht Orte, zu denen sie Spuren des Tristero-Posthorns führen. Trotz der mühsamen Ermittlungen bringt ihre Detektivarbeit jedoch kaum Fortschritte, kaum Erkenntnisse, die ein absehbares Ende der Testamentsvollstreckung ankündigen würde. Trotz zahlreicher Indizien und Hinweisen ${ }^{201}$, die Oedipa gesammelt hat, bleibt der Sinn des Tristero konsequent im Unklaren: „Either Tristero did exist, in its own right, or it was being persumed, perhaps fantasied by Oedipa, so hung up on and interpenetraded with the dead man's estate.“ (CL 49, 75) Die zunehmende Skepsis der Protagonistin über die reale Existenz des Systems, das sie aufzuspüren versucht, und die Strapazen all der Begegnungen mit mutmaßlichen Eingeweihten münden endlich in den Verdacht einer mentalen Schwäche. ${ }^{202}$ Oedipa scheint in ihrer Verzweiflung einen Punkt erreicht zu haben, an dem die Belastungen dieser ungewöhnlichen Testamentsvollstreckung ihre psychophysischen Grenzen erreicht haben. Was sie jedoch erwartet, sind neue Hinweise, Informationen zur Geschichte Tristero ${ }^{203}$, ein Durchbruch scheint wieder in der Luft zu hängen und dann die nächste Enttäuschung, die in eine noch nüchternere Erkenntnisbilanz mündet: „But left it alone, anxious that her revelation not expand beyond a certain point. Lest, possibly it graw larger than she and assume her to

markiert. Die Äußerung scheint meines Erachtens zwar auf eine Entdeckung hinzuweisen, bestimmt aber keinesfalls, ob die Protagonistin den neuen Erkenntnisweg praktisch umzusetzen weiß.

${ }^{200}$ Vgl. Annibale Picicci, Noise Culture. Kultur und Ästhetik des Rauschens in der Informationsgesellschaft am Beispiel von Thomas Pynchon und Don DeLillo, Berlin 2001, S. 74.

201 „Es war der Gegner des Postsystems der Thurn und Taxis in Europa, sein Symbol war ein gedämpftes Posthorn, irgendwann vor 1853 war es in Amerika aufgetaucht und hatte den Pony-Expreß und die WellsFargo-Leute bekämpft, entweder als Desperados, als schwarzgekleidete Gesetzlose, oder verkleidet als Indianer, und es hatte überlebt, es bestand heute noch, in Kalifornien, als Kommunikationskanal für Leute mit unorthodoxen sexuellen Neigungen, für Erfinder, die an die Existenz eines Maxwellschen Dämons glaubten..." ",[...] it had opposed the Thurn and Taxis postal system in Europe; its symbol was a muted post horn; sometime before 1853 it had appeared in America and fought the Pony Express and Wells Fargo, either as outlaws in black, or disguised as Indians; and it survived today, in California, serving as a channel of communication for those of unorthodox sexual persuasion, inventors who believed in the reality of Maxwell's Demon..." $(C L 49,75)$ 202, ,[...] I really think I am going out of my head.“ $(C L 49,77)$ „She might well be in the cold and sweetless meat - hooks of psychosis." (CL 49, 91)

${ }^{203}$ Der Name selbst sollte nämlich von einer Person stammen: „In 1577 [...] At this point the founding figure enters the scene: Hernando Joaquin de Tristero y Calavera, perhaps madman, perhaps an honest rebel, according to some only a con artist." ( $C L 49,109$ f) Es folgt eine Geschichte voller Namen und verwirrender Ereignisse. Tristero sollte ein eigenes Postsystem aufgebaut haben, das sein Name dann für sich übernommen hat und sich über Jahrhunderte zu einem System entwickelt hat, das die staatlichen Postmonopole subvertiert hat. 
itself.“ (CL 49, 115) Das Gefühl der Ausweglosigkeit lässt sie verzweifelt an Alternativen denken, die sogar ein Komplott und Paranoia in Erwägung ziehen. Sie kann es aber auch nicht ausschließen, dass „gynaecologist has no test for what she was pregnant with.“ (CL 49, 121), „her isolation complete $[\ldots]$ “. $(C L 49,122)$

„[W]ith the courage you find you have when there is nothing more to lose“ $(C L 49,126)$ betritt Oedipa das Auktionshaus, wo die Versteigerung von Inveraritys Briefmarkensammlung stattfinden wird. Die Tristero-Fälschungen sollten als Versteigerungsobjekt No.49 angeboten werden. Ein geheimnisvoller Bieter, der sein Interesse an den Fälschungen annoncierte, soll erscheinen:

„She was not sure what she'd do when the bidder revealed himself. She had only some vague idea about causing a scene violent enough to bring the cops into it and find out that way who the man really was.“ (CL 49, 126)

Der Roman endet, während Oedipa auf die Versteigerung wartet. Die (Auf)Lösung bleibt aus.

Das Rätsel des Tristero wird von den Literaturwissenschaftlern gern und intensiv reflektiert und die diesem wahrscheinlich geheimnisvollsten der Phänomene in $C L 49$ gewidmeten Analysen liefern sehr unterschiedliche Deutungen. Manche Interpreten, wie z.B. Tanner erheben die Beziehung der Protagonistin zu dieser geheimnisvollen Entität zu der wichtigsten Frage des Romans: „What the book raises as a central and insoluble problem is whether Oedipa has discovered or hallucinated her synthesization which adds up to The Tristero System.“ ${ }^{204}$ Tanner fasst präzis zusammen, was diesem System zuzuschreiben sei:

„The Tristero System in its present-day manifestation is that underground America made up of all the 'disinherited' - racial minorities, homosexuals, the poor, the mad, the lonely and the frightened. It also contains revolutionaries from both extremes of the political spectrum who are crazily dedicated to the overthrow of the present society. These inhabitants of the night are both pathetic and frightening; as the concealed pun in Tristero suggests - it represents both the sadness and the terror of America."205

Dieses - allem Anschein nach - real existierende Tristero dürfe aber auch um eine metaphysische Komponente erweitert werden:

„The possible existence of The Tristero is [...] associated with the possible existence of 'transcendent' meaning, almost equivalent to a redemptive vision of another America behind the

204 Tony Tanner, City of Words. American Fiction 1950-1970, London 1971, S. 176.
${ }^{205}$ Ebd., S. 177. 
material concretions of the land. The Tristero is also associated with that yearning for diversity, a world of unprogrammed possibilities [...]"206

Es ist kaum möglich, den genauen Moment zu lokalisieren, ab dem Oedipa angesichts der wachsenden Unsicherheit in die Paranoia abzugleiten beginnt. Es wäre nämlich schwierig, ihre Verzweiflung mit Hilfe einer Skala einzuschätzen. Ihre Suche zeigt sich als dermaßen belastend, dass sie irgendwann zugestehen muss, dass sie mit der Aufgabe in jeder Hinsicht überfordert sei. Wäre dann Paranoia bloß eine passende Rechtfertigung oder sollte sie eher als Schrei der Verzweiflung gelesen werden? Tanner bemerkt, Paranoia resultiere aus der Konfrontation der Hoffnung mit der Angst, aus der Befürchtung, ,that someone else is patterning your life, that there are all sorts of invisible plots afoot to rob you of your autonomy of thought and action, that conditioning is ubiquitous." ${ }^{207}$ Wenn die eigenen Wahrnehmungen verdächtig werden, wird die Rezeption paranoid:

„The paranoid then finds his personal, private knowledge of himself and his world overthrown by the system's conspiracies against his experience. In Pynchon's work paranoia represents the infinite regress of character's self awareness: a separate man can never be paranoid enough. His experience of discovery may be a conditioned response. The discovery itself may be a planned act requiring the planted evidence., ${ }^{208}[\ldots]$

„Paranoia urges Oedipa to literally or symbolically separate [herself] from the systems that encroach upon [her]. But separation of self through paranoiac modes of perception or existence does not halt the systems' operations. Mystery, uncertainty, habitual doubt and suspension of judgment, are facts of the paranoids' condition."209

Robert Ratcliff Hill ist der Meinung, dass Pynchon die Paranoia in Form einer 'Psychose der Interpretation' gestaltet: „His paranoids are certain only that some system may mount a conspiracy against experience, but their investigations, although pathologically and ludicrously detailed, are logical. ${ }^{, 210}$ In der mentalen Situation, in die sich Oedipa während ihrer Suche hineinmanövriert hat, könnte Paranoia als ein Warnsignal funktionieren aber auch als der wahre Kern ihrer Identität, dessen Enthüllen jedoch ein Zustand permanenter Ambiguität mit sich brächte. „If paranoia is the perceptual psychosis of detailed, logical

\footnotetext{
${ }^{206}$ Ebd., S. 178.

207 Tanner, a.a. O., S. 15.

${ }^{208}$ Robert Ratcliff Hill, Epistemological dilemmas in the works of Norman Mailer and Thomas Pynchon: The themes and motifs of systematization, paranoia and entropy, Tulsa 1981, S. $179 f$.

${ }^{209}$ Ebd., S. 179.

${ }^{210}$ Ebd., S. 105.
} 
interpretation, its fruits [...] are endless doubt and uncertainty." ${ }^{211}$ Hill fügt hinzu, dass Paranoia die Fähigkeit der paranoiden Protagonisten teste, in einem Zustand permanenter Unsicherheit $\mathrm{zu}$ existieren, „by cultivating a willful suspension of judgment favoring not skepticism but potentiality and possibility." 212 In $C L 49$ ist es schwierig, die Einstellung des Erzählers zu den Paranoikern einzuschätzen, er scheint hier nämlich neutral zu wirken. ${ }^{213}$

Das Thematisieren der Paranoia in CL 49 wird von einigen Interpreten zu Recht in der epistemologischen Perspektive situiert. Im Fall Oedipas fungiert Paranoia als ein Weg, ihre Entscheidungen und mögliche Alternativen $\mathrm{zu}$ vergleichen und miteinander $\mathrm{zu}$ kontrastieren. ${ }^{214}$ Nicht ganz klar ist dabei jedoch Hills These: „In the Crying of Lot 49 Pynchon renders paranoia as the last psychic bastion of free experience and perception." 215 Rätselhaft ist dabei Hills Hinweis auf ein Zitat, das Oedipas abschließende Auseinandersetzung mit ihrer Wahrnehmungsart und ihrer bisherigen Erfahrung, die ihr paranoides Bewusstsein entfaltete, zum Ausdruck bringt ${ }^{216}$ :

„She had heard all about excluded middles; they were bad shit, to be avoided; and how had it ever happened here, with the chances once so good for diversity? For it was now like walking among matrices of a great digital computer, the zeros and ones twines above, hanging like balanced mobiles right and left, ahead, thick, maybe endless." (CL 49, 125)

Der Textausschnitt gehört zu den m.E. geheimnisvollsten im Roman. Sein Erscheinen auf der vorletzten Seite, am Ende der gescheiterten Testamentsvollstreckung, wo sich Oedipas Gedanken zum letzten Mal verdichten, zeugt von seiner Wichtigkeit für den letzten Versuch der Protagonistin, angesichts der totalen Verzweiflung doch zu schlüssigen Alternativen zu gelangen. Diese werden wie eine Art Beruhigungsübung von Oedipa reihenweise verbalisiert: „Behind the hieroglyphic streets there would either be a transcendent meaning, or only the earth.“(CL 49, 125).

Unklar und wenig einleuchtend bleibt meines Erachtens Hills Versuch, diese Überlegungen Oedipas im Kontext der Paranoia zu situieren. Direkt haben ihre Gedanken eher etwas mit

\footnotetext{
${ }^{211}$ Ebd., S. 107.

212 Ebd.

${ }^{213}$ Eine nachdrücklich negative Einstellung zum Paranoiden äußert der Erzähler dagegen im größten Roman Pynchons - Gravity's Rainbow: „Paranoids are not paranoids [...] because they're paranoid, but because they keep putting themselves, fucking idiots, deliberately into paranoid situations." Thomas Pynchon, Gravity's Rainbow, S. 292. (zit. nach Hill, a.a.O., S. 115.)

214 Vgl. Hill, a.a.O., S. 117.

215 Ebd, S. 161.

216 Vgl. ebd.
} 
dem Erkenntnisfortschritt gemeinsam, der in der Art der Zusammenfassung eines Projektes zum Ausdruck kommt.

Eine interessante Bemerkung formuliert Joseph W. Slade, indem er der anfänglichen Verwirrung Oedipas ihre spätere Paranoia als einen erwünschten Zustand entgegenstellt. Gerade hier fungiert die paranoide Einstellung im Sinne eines alternativen Erkenntniswegs, der die gewohnte Episteme in Frage stellt: „Paranoia is a way of structuring, or restructuring, the world along comprehensible lines, and if it does not reveal the Word, it may suffice until the Word does manifest itself. In the modern world, Pynchon's universe, paranoia is rightful heir to rationalization." ${ }^{217}$ In der Auswertung der Ergebnisse dieser Erkenntnisstrategie darf jedenfalls eins nicht vergessen werden: Die Paranoia impliziert nämlich stets die Möglichkeit, dass die Deutungen des von dem Paranoiker Wahrgenommenen falsch sind, dass z.B. ein Komplott, das gegen ihn geschmiedet worden ist, gar nicht existiert oder in einer völlig anderen Form ausgeheckt war. ${ }^{218}$ Auf eine ähnliche Möglichkeit macht auch Hanjo Berressem aufmerksam: „Paranoia is a necessary and desired structure of thought.““219 Im Gegensatz zu den anderen Interpreten, die Oedipas Paranoia als ein Fall der verzerrten Wahrnehmung der Wirklichkeit sehen (eine Wahrnehmung also, die sich gegen mehr objektive Wahrnehmungen stellt), behauptet Berressem, dass es eine objektive Wahrnehmung der Realität in CL 49 gar nicht gebe:

„In fact, the story traces Oedipa's journey from a secure space within cultural networks, part of whose function is exactly to cover up the originary paranoiac origin of reality and with it their own paranoiac roots, to the Lacanian realization that culture and the symbolic are only a 'network $[\ldots]$ over the entirety of things, over the totality of the real', and that language 'inscribes on the plane of the real this other plane, which we here call the plane of the symbolic'. Lacanian theory stresses the construction of symbolic space, however, whereas Lot 49 follows in detail what happens when this network begins to disintegrate, ultimately revealing the void it is made to cover up."220

Die Situation der Protagonistin am Ende des Romangeschehens zeugt nach Berressem davon, dass sie zwar zur Paranoikerin wurde, ihre Paranoia jedoch keine klinische oder pathologische, sondern eine ontologische sei und eher eine schützende Funktion habe. ${ }^{221}$

\footnotetext{
${ }^{217}$ Joseph W. Slade, Thomas Pynchon, New York; Bern; Frankfurt am Main; Paris 1990, S. 226.

${ }^{218}$ Vgl. ebd., S. 226.

${ }^{219}$ Der Satz stammt von Leo Bersani, Pynchon, Paranoia, and Literature. Hier zitiert nach Hanjo Berressem, Pynchon's Poetics Interfacing Theory and Text, Urbana and Chicago 1993, S. 116.

${ }^{220}$ Ebd., S. 94.

${ }^{221}$ Vgl. ebd., S. 109. Ich vermute, Berressem denkt die ,ontologische Paranoia' im Sinne einer obsessiven Unsicherheit bezüglich dessen, was Oedipa als real gegeben und was als eventuell imaginiert einzustufen sucht.
} 
In diesem Kontext untersucht CL 49 auch John Dugdale und weist darauf hin, dass sich unter der (Text)Oberfläche eine Reihe latenter Verbindungen aufspüren lassen, die den psychoanalytischen Phänomenen ähnlich seien. Er nennt hier Aberglaube, Narzissmus, Projektion, Paranoia, Delirium, Trauer und das Unheimliche: „The novel does not make it explicit that projection is the basic mechanism of paranoia, or that the latter is a narcissistic disorder, or that 'deliria' is the word used in the Schreber case for the paranoid's delusional formations." ${ }^{222}$ All diese Freudschen Begriffe lassen sich nach Dugdale im Roman in Form einer krassen und komischen Mixtur wiederfinden: eine Gruppe junger Musiker heißt The Paranoids, der Name der Stadt ist San Narcisso, der Psychoanalytiker Oedipas - Dr. Hilarius wendet manchmal das psychoanalytische Vokabular an, obwohl er im Endeffekt zur Satirefigur wird, und der Regisseur des Stücks The Courier's Tragedy - Driblette erfindet sich in der Rolle eines Projektors im Planetarium. Und gerade diese Erklärung Dribletts: „I'm the projector at the planetarium, all the closed little universe visible in the circle of that stage is coming out of my mouth, eyes, sometimes other orifices also." (CL 49, 54), ist nach Dugdale ein interessantes Beispiel „of an overdetermined element, with two different sets of latent associations: paranoia in Freud, on the one hand, and the Romantic figure of the author as light-source on the other.“ ${ }^{\text {223 }}$ Dugdale behauptet, die Kenntnis der Freudschen Ideen und Begrifflichkeit könne die Lektüre von $C L 49$ wesentlich erleichtern, ,in particular, the repetition in various forms of 'projection' (although it is never used in its Freudian sense) establishes a vital link between defense, repression, paranoia, on the one hand and fantastic perception on the other." 224

Die literarästhetische Gestaltung der Paranoia bildet zweifelsohne eines der kniffligeren Momente in $C L$ 49. Ihre ausgeklügelte Ästhetisierung scheint ihre unterschiedliche Problematisierungen willkommen zu heißen und je nach der Betrachtungsperspektive können verschiedene Aspekte ihrer möglichen Deutungen hervorgehoben werden. Der mentale Zustand der Protagonistin am Ende des Romans erfordert vor allem die Beantwortung der

\footnotetext{
Ihre mögliche schützende Funktion könnte dabei darauf beruhen, dass die Protagonistin die Existenz unterschiedlicher, sich aufeinander beziehender Welten ahnt und diese Vorstellung im Sinne einer Erkenntnis begreift.

${ }^{222}$ John Dugdale, Thomas Pynchon Allusive Parables of Power, Houndmills, Basingstoke, Hampshire, London 1990, S. 8; "In fact, all these terms are interrelated in Freud, although the text gives no overt indication that they are. In Totem and Taboo projection in mourning is treated as the origin and model of other projections which populate the universe with spirits in the animistic (magical, superstitious) world system. These projections are directly compared to the myths of 'the ingenious paranoic Schreber'. They reflect and sustain the primitive's faith in what Freud calls the narcissistic omnipotence of thought; which survives in the modern adult as a residual superstition which renders possible the experience of the uncanny."

${ }^{223}$ Ebd., S. 9.

${ }^{224}$ Ebd., S. 129.
} 
Frage, ob sie im Laufe ihrer detektivischen Arbeit epistemologisch strategisch oder eher spontan-intuitiv vorgegangen war. Waren ihre Erkenntnisstrategien präzis geplant, bleibt weiterhin die Frage nach den Gründen des Scheiterns der Queste und der Flucht in die Paranoia. Und letztendlich muss auch noch geklärt werden, ob selbst Paranoia einen Teil der Strategie des Sortierens bildet oder vielleicht als eine Art Gegenstrategie, als der letzte Hoffnungsanker für das Bewusstsein angesichts der permanenten Zerstreuung des Sinns fungieren sollte.

Oedipas Paranoia resultiert allem Anschein nach aus ihrer Obsession der gestörten Verfügbarkeit des permanenten Sinns. Die literarische Inszenierung dieser Obsession, wie wir sie in CL 49 wahrnehmen, wird mit anderen Fäden des Romangeschehens und mit anderen Phänomenen verflochten, deren Untersuchung weitere Aspekte hervorbringt. Als weit komplexer und verwirrender als die Frage der Paranoia wird das Phänomen der Entropie konzipiert. Diese von den Naturwissenschaftlern im 19. Jahrhundert entdeckte Erscheinung musste Pynchon besonders interessieren, da er bereits einer seiner früheren Erzählungen den Titel Entropy ${ }^{225}$ gab. Einer expliziten Inszenierung der Entropie wird in $C L 49$ lediglich eine kurze Passage gewidmet. Implizit lässt sich aber meines Erachtens die Strukturierung des Romangeschehens oder genauer noch der Informationszerstreuung im Sinne der zunehmenden Entropie verstehen. Beide Momente beeinflussen stark die Lektüre von CL 49, indem sie für die Zunahme der Verwirrung verantwortlich sind. Diesen Mechanismus möchte ich im folgenden Kapitel unter die Lupe nehmen.

\footnotetext{
${ }^{225}$ Entropy befindet sich in dem Band Slow Learner: early stories, Boston 1984.
} 


\subsection{Die Doppelfunktion der Entropie in $C L 49$}

„Die Energie der Welt ist constant.“

„Die Entropie der Welt strebt einem Maximum zu.“

Rudolf Clausius

Das Phänomen und der Begriff der Entropie stammen aus den Naturwissenschaften und sind mit dem Zweiten Hauptsatz der Thermodynamik verbunden. Dieser besagt im Groben, „dass geschlossene Systeme zur Herstellung eines Zustands niedrigster Differenzierung ihrer Ordnung tendieren“6226, und d.h., dass „Entropie im Weltall einem Maximum zustrebe; denn das bedeutete [...], daß die Energie des Universums zwar insgesamt konstant blieb, sich aber immer mehr räumlich verteilte und verdünnte.“ ${ }^{627}$ Für Physiker „definiert sich die Entropie als das quantitative Maß für den Grad der Unordnung in einem System.“228 Das eigentliche Problem der Bedeutung der Entropie innerhalb der Geisteswissenschaften resultiert aus den gleichen Schwierigkeiten, die dieser Begriff nach seiner Übertragung in die Informationstheorie bereitet hat:

„Dort wird Ordnung als der Träger von Information bezeichnet, weil Ordnung als das Gegenteil von Entropie definiert ist und Entropie als das Maß für Unordnung gilt. Information übermitteln heißt Ordnung schaffen. [...] Weil nun aber die Entropie mit dem Wahrscheinlichkeitsgrad der gegebenen Situation wächst, tut die Information das Gegenteil: Sie wächst mit dem Grad der Unwahrscheinlichkeit. Je unwahrscheinlicher ein Geschehen, um so mehr Information vermittelt es. [...] Was für eine Geschehensabfolge ist es nun aber, die am wenigsten voraussehbar ist und daher ein Maximum an Information vermittelt? Offensichtlich eine vollkommen ordnungslose, denn wenn wir vor einem Chaos stehen, können wir niemals voraussagen, was sich im nächsten Augenblick ereignen wird. Daraus folgt, daß vollkommene Unordnung ein Höchstmaß an Information übermittelt; und da man Ordnung durch Information mißt, so kommt also höchste Ordnung durch höchste Unordnung zustande.“‘229

\footnotetext{
${ }^{226}$ Gabriele Schwab, a.a.O., S. 227. „Der popularisierende Einzug des Zweiten Hauptsatzes der Thermodynamik in Humanwissenschaft, Literatur und Alltagsbewußtsein hat eine Eigenbedeutung, die von seiner Rezeptionsgeschichte in den Naturwissenschaften unabhängig ist." Schwab erinnert nach Arnheim an die verfälschende Deutung dieser physikalischen Entdeckung, die im Rahmen der geisteswissenschaftlichen Reflexion hervorgebracht wurde und die aus der Annahme resultiert, „unsere Welt bewege sich von einem Zustand relativer Ordnung auf einen Zustand absoluter Unordnung hin. [...] So konnte die Entropiemetapher apokalyptische Konnotationen annehmen und das diffuse und verbreitete Unbehagen an der Kultur mitsamt den Entgrenzungsbestrebungen symbolisieren."

${ }_{227}$ Rudolf Arnheim, Entropie und Kunst: ein Versuch über die Unordnung und Ordnung, Köln 1979, S. 18.

${ }^{228}$ Ebd.

${ }^{229}$ Ebd., S. $25 f$.
} 
Die Ursache dieser - wie es Arnheim zutreffend bezeichnet - , babylonischer Konfusion“ liege darin, dass „wir im gewöhnlichen Leben von Ordnung sprechen, wenn wir eine Struktureigenschaft meinen. Im rein statistischen Sinne dagegen kann sich der Begriff der Ordnung auf jede Abfolge oder Anordnung beziehen, von der es unwahrscheinlich ist, daß sie aus bloßem Zufall zustande kommt. ‘230

Dank Claude Shannon, der ,Information“ als physikalische Größe erfasst, und Norbert Wiener, der die informationelle Entropie für das Laienpublikum popularisierte, konnte sich der primär naturwissenschaftliche Begriff der Entropie in den Kulturwissenschaften fest etablieren. Wieners Buch The Human Use of Human Beings: Cybernetics and Society enthielt in erster Linie „eine Warnung vor den Auswirkungen der zunehmenden Entropie im Lebensraum der Menschen - der Welt - und im Verständigungsmedium der Menschen - der Sprache” ${ }^{, 231}$. Der Warnung wurde jedoch ein Trost beigefügt, dass „,the theory of entropy, and the considerations of the ultimate heat-death of the universe, need not have such profoundly depressing moral consequences as they seem to possess at first sight," Inseln mit abnehmender Entropie sei." ${ }^{233}$ Dieser (subtil gewonnene) Optimismus resultierte aus dem Perspektivenwechsel von thermodynamischer zu informationeller Entropie:

„So wie in der Thermodynamik die Menge an Energie, die in Arbeit umgewandelt werden kann, hängt auch in der Kybernetik die Menge der Information, die vermittelt werden kann, von der komplementären Menge an Entropie ab. Und so wie in der statistischen Mechanik eine Zunahme an Entropie als eine molekulare Bewegung vom unwahrscheinlichsten zum wahrscheinlichsten Zustand, also von Organisation und Differenzierung $\mathrm{zu}$ Chaos und Gleichheit, verstanden wird, so wird auch in der Informationstheorie die Zunahme an Entropie als eine Bewegung von mehr zu weniger Information, also von unerwarteten und deshalb informativen zu vorhersehbaren und deshalb inhaltsleeren Botschaften verstanden.“234

\footnotetext{
${ }^{230}$ Ebd., S. 26

${ }^{231}$ Peter Freese, Vom apokalyptischen zum entropischen Ende: Thermodynamik, Informatik und Literatur, Paderborn 2006, S. 32.

${ }^{232}$ Norbert Wiener, The Human Use of Human Beings: Cybernetics and Society, Boston 1950, S. 26.

${ }^{233}$ Peter Freese, Vom apokalyptischen zum entropischen Ende: Thermodynamik, Informatik und Literatur, Paderborn 2006, S. 32.

${ }^{234}$ Ebd. Angesichts der Tatsache, dass Pynchon das Phänomen der Entropie wiederholt in seinen Texten inszeniert, scheint es für sein tieferes Verständnis nützlich zu sein, Entropie in ihrem naturwissenschaftlichen und informationstheoretischen Kontext klar unterscheiden zu können. Auf die Bedeutung dieser Unterscheidung macht noch klarer Arnheim aufmerksam: „Dem Informationstheoretiker geht es immer um eine Einzelabfolge oder um eine auf eine solche Einzelabfolge reduzierte Anordnung von Elementen. Er berechnet die Wahrscheinlichkeit für ihr Auftreten, indem er feststellt, wie viele solcher Abfolgen möglich sind [...] In der Thermodynamik hingegen bezieht sich der Entropiebegriff nicht auf die Wahrscheinlichkeit für die zeitliche Aufeinanderfolge von Elementen in einer Serie, sondern auf die Wahrscheinlichkeit für die Verteilung der Elemente in einem gegebenen Zustand. Je weiter entfernt ein solcher Zustand von einer Zufallsverteilung
} 
Diese spezifische Neuakzentuierung und zugleich Mutation des Zweiten Gesetzes der Thermodynamik brachte eine neue Betrachtungsmöglichkeit des Phänomens der Entropie zum Ausdruck, die Akzente wurden von der Gefahr des Todes durch Wärme, (bzw. des Todes der Wärme) auf die Gefahren des Todes der Kommunikation verschoben. ${ }^{235}$ Im Gegensatz zur physikalischen Phänomenen, die der Mensch lediglich entdecken und benennen kann, könnte die informationelle Entropie durch ein gezieltes menschliches Tun potentiell beeinflusst werden, der entropische Verfall eines Teils der Welt könnte „mithilfe der bedeutsamsten antientropischen Aktivität, derer Mensch fähig ist, nämlich der Konstruktion bedeutungsvoller Botschaften“‘236, angehalten oder zumindest verlangsamt werden.

Sobald das Phänomen der Entropie literarästhetischen Ausdruck in den Werken bekannter amerikanischen Autoren fand ${ }^{237}$, wurde es zur großen Herausforderung für die Literaturwissenschaft, jenes plausibel $\mathrm{zu}$ interpretieren und $\mathrm{zu}$ bewerten. Eine besondere Schwierigkeit und Verwirrung resultierte aus der Tatsache, dass „die Übernahme des Entropiekonzepts die Vorstellungen von Ordnung und Unordnung, die in der Physik und der Kybernetik als wertfreie Beschreibungen molekularer oder informationeller Aggregatszustände verwandt werden, mit allerlei unzulässigen ästhetischen Implikationen““238 auflud. Meistens unklar bleiben dabei auch die Positionen der Interpretierenden in puncto, ob sie Entropie in der Informationstheorie und Entropie in der statistischen Mechanik als identisch oder nur als analog betrachten. ${ }^{239}$

Wie bereits erwähnt, wird die Protagonistin von $C L 49$ mit dem Phänomen der Entropie direkt konfrontiert. Da sich das Phänomen der (physikalischen) Entropie nur sehr beschränkt

\footnotetext{
ist, um so geringer ist die Entropie und um so höher das Niveau der >Ordnung<. Es besteht also der folgende Unterschied zwischen den beiden Methoden: Von einer stark zufallshaften Abfolge wird ausgesagt werden, daß sie viel Information vermittelt, weil Information es mit der Wahrscheinlichkeit des Eintretens einer bestimmten Abfolge zu tun hat; eine ähnlich zufallshafte Verteilung besitzt vom Standpunkt der Thermodynamik aus eine hohe Wahrscheinlichkeit, weil unzählige Verteilungen dieser selben Art möglich sind." Rudolf Arnheim, a.a.O., S. $29 f$.

${ }^{235}$ Vgl. Peter Freese, From Apocalypse to entropy and beyond: The second law of thermodynamics in Post-War American Fiction. S. 305.

${ }^{236}$ Peter Freese, Vom apokalyptischen zum entropischen Ende: Thermodynamik, Informatik und Literatur, S. 33.

${ }^{237}$ Freese führt nach Eric Zenzey dreizehn Gründe an, warum Entropie in metaphorisierten Formen eine so große Popularität in Kultur- und Literaturwissenschaften gefunden hat. S. Peter Freese, From Apocalypse to entropy and beyond: The second law of thermodynamics in Post-War American Fiction. S. 301.

${ }^{238}$ Peter Freese, Vom apokalyptischen zum entropischen Ende: Thermodynamik, Informatik und Literatur. S. 35

${ }^{239}$ Vgl. ebd., S. $35 f$ „Beide Problemfelder sind eng miteinander verknüpft, denn wenn man einen Entropiezuwachs als einen Informationsverlust und umgekehrt versteht, wird man natürlich leichter die Identität der beiden Entropiekonzepte zugestehen als wenn man auf der ,objektiven' Qualität thermodynamischer Entropie beharrt und deshalb informationelle Entropie allenfalls als heuristische Analogie anerkennt."
} 
visualisieren lässt ${ }^{240}$, kann es nicht verwundern, dass Versuche einer literarästhetischen Darstellung dieser Erscheinung entweder einen sehr verwirrenden oder einen irrsinnigen Ausdruck bekommen. Im Prozess der Lektüre wird der Leser darüber hinaus mit einer Art ,informationeller' Entropie konfrontiert, deren strategischer Einsatz auf die konsequente Störung der Sinnbildungsversuche zielt. Die permanente Unmöglichkeit, die Bedeutung des Romangeschehens zu konstituieren, mündet letztlich in eine interpretatorische Desorientierung.

Während der Begegnung Oedipas mit dem Wissenschaftler Nefastis soll die Protagonistin mit dem Phänomen der Entropie direkt bekannt gemacht werden:

„He began then, bewilderingly, to talk about something called entropy. The word bothered him as much as ,Trystero' bothered Oedipa. But it was too technical for her. She did gather that there were to distinct kinds of this entropy. One having to do with heat-engines, the other to do with communication. The equation, for one, back in the ' 30 s, had looked very like the equation fort he other. It was a coincidence. The two fields were entirely unconnected, except at one point: Maxwell's Demon. As the Demon sat and sorted his molecules into hot and cold, the system was said to lose entropy. But somehow the loss was offset by the information the Demon gained about what molecules were where. 'Communication is the key' cried Nefastis. 'The Demon passes his data on to the sensitive, and the sensitive must reply in kind. There are untold billions of molecules in that box. The Demon collects data on each and every one. At some deep psychic level he must get through. The sensitive must receive that staggering set of energies, and feed back something like the same quantity of information. To keep it all cycling. On the secular level all we can see is one piston, hopefully moving. One little movement, against all that massive complex of information distroyed over and over with each power stroke." 'Help", said Oedipa, 'you're not reaching me.' 'Entropy is a figure of speech, then,' sighed Nefastis, 'a metaphor. It connects the world of thermodynamics to the world of information flow. The Machine uses both. The Demon makes the metaphor not only verbally graceful, but also objectively true.““( $C L 49,72 \mathrm{f})$

Die Maschine Nefastis‘ und genauer gesagt die Tätigkeit des Sortierens, die der Dämon bewerkstelligt, wird zu einer der wichtigsten Metaphern, die in CL 49 zahlreiche Szenen verbindet. $^{241}$ Bevor Oedipa den Erfinder Nefastis aufgesucht hat, war sie bereits über die

\footnotetext{
${ }^{240}$ Einen halbwegs gelungenen Versuch einer populärwissenschaftlichen Darstellung der Entropie liefert der Astrophysiker Harald Lesch: http://www.youtube.com/watch?v=4VSOLR5ilMU (Stand: 9.09.2013)

${ }^{241} \mathrm{~J}$. Kerry Grant macht auf die grundlegenden Schwierigkeiten aufmerksam, die der Leser bei der richtigen Vorstellung der Tätigkeit des Dämons bewältigen muss: „The difficulty for the reader lies in the fact that the
} 
Genialität der Maschine informiert. Auf einer Versammlung der Aktionäre der Firma Yoyodyne, die im Besitz Inveraritys war, stößt sie auf Stanley Koteks, der ihr die Geschichte der genialen Erfindung erzählt. Laut Koteks beruht die Größe der Entdeckung darauf, dass man dank dem sortierenden Dämon keine echte Arbeit in das System zu investieren braucht, „[s]o you would be violating the Second Law of Thermodynamics, getting something for nothing, causing perpetual motion.“ ( $C L$ 49, 59) Mit einer überraschend kompetent klingenden Frage quittiert Oedipa Koteks Erklärung: „'Sorting isn’t work?““ (CL 49, 59), als ob sie sich plötzlich an ihre Aufgabe als Testamentsvollstreckerin erinnert hätte: „'It's mental work', Koteks said, 'but not work in the thermodynamic sense."“ (CL 49, 59) Diese raffinierte, halb wissenschaftlich, halb metaphorisch formulierte Fassung physikalischer und kybernetischer Gesetze, scheint einen der plausibleren Grundgedanken zu bilden, auf Grund dessen das Romangeschehen einleuchtend interpretiert werden könnte. Das Vermengen von der wissenschaftlichen und metaphorischen Sprache wird aber keinen Ansatzpunkt markieren, von dem aus die interpretatorische Arbeit schnelle Erfolge erzielen könnte.

„Like the Demon, she [Oedipa - K.S.] tries to order the signs and symbols around her into some kind of operational meaning. But sorting is work, and she requires for this task some infusion of energy from the outside to counter the entropic movement inside toward disorganization, sameness, and death. [...] The Nefastis' Machine not only connects the worlds of thermodynamics and information, but it casts a shadow on Oedipa's entire enterprise. Even Nefastis knows that his belief in his invention's workability rests on a visual metaphor: the identity of the equations for "entropy" in thermodynamics and the average unit in information theory. The fact that they look the same but mean different things is a characteristic of clues in Pynchon's writing.,"242

Obwohl man die Begrifflichkeit, wie ,Entropie‘, ,Ordnung‘ und ,Unordnung' (im Fall naturwissenschaftlicher Konzepte) mit keinerlei Wertung versehen darf, scheint es in den Geisteswissenschaften kaum möglich $\mathrm{zu}$ sein, dieses (naturwissenschaftliche) Tabu aufrechtzuerhalten. Die Wirkung der Maschine Nefastis' scheint in diesem Fall ein klar wertendes Fazit abzugeben: „Nefastis thinks the entropy of information theory is ,positive“ and can counter the ,negative“ entropy of thermodynamics.“ ${ }^{243}$ Diese Positivität der informationellen Entropie versus Negativität der physikalischen Entropie impliziert

demon scenario asks for a counterintuitive identification of disorder with uniformity." J. Kerry Grant, A Companion to The Crying of Lot 49, Athens 1994, S. 68.

242 Thomas Schaub, Pynchon: the voice of ambiguity, Urbana 1981, S. 31.

${ }^{243}$ Ebd. 
Konsequenzen sowohl für die Romanfiguren als auch für die literatur-, und kulturwissenschaftliche Deutung. Diese Unterscheidung sollte somit in jeder detaillierten Untersuchung von $C L 49$ klargemacht werden.

Oedipas erste, indirekte Konfrontation mit Entropie im Kontext der Informationszirkulation lässt sich in dem Moment lokalisieren, in dem ihre Sensibilisierungsphase (sensitizing) beginnt. Während ihres ersten Aufenthalts in San Narciso, bekommt sie einen Brief von ihrem Mann:

„It got seriously under way, this sensitizing, either with the letter from Mucho or the evening she and Metzger drifted into a strange bar known as The Scope. [...] It may have been an intuition that the letter would be newsless inside that made Oedipa look more closely at its outside, when it arrived. At first she didn't see. It was an ordinary Muchoesque envelope, swiped from the station ordinary airmail stamp, to the left of the cancellation a blurb put on by the government, REPORT ALL OBSCENE MAIL TO YOUR POTSMASTER. Idly, she began to skim back through Mucho's letter after reading it to see if there were any dirty words. [...] 'What it a potsmaster?' [...] 'I'm supposed to report all obscene mail to my potsmaster.' 'So they make misprints', Metzger said, 'let them. As long they're careful about not pressing the wrong button, you know?"” (CL 49, 29f)

Obwohl die Szene hier endet und der irritierende Druckfehler ohne Erklärung bleibt, kann die unschuldige Buchstabenverschiebung als eine bedeutsame Spur untersucht werden. Metaphorisch ließe sich diese Verschiebung als ,the first break in the symbolic universe by shifting her [Oedipas - K.S.] attention from signified to the signifier ${ }^{644}$ deuten. Der Fehler, diese Störung in der Sprache, ,yet this minimal mistake is the first instance at which the tissue of the complex and vast discursive network that makes up Oedipa's reality begins to give way. “245 Der (angebliche) Druckfehler erscheint m. E. im Roman als das erste klare Symptom einer fortschreitenden, für den Leser und die Protagonistin beunruhigend-verwirrender Lockerung oder Befreiung der Zeichen von ihren Bedeutungen.

Ein höchst raffiniertes, obwohl indirekt wahrnehmbares Potential der Entropiezunahme, entfalten in $C L 49$ die seltsamen Namen der Figuren: „The characters“ names seem to be simultaneously programmatic and inappropriate." ${ }^{246}$ Die Herausforderung eines treffenden Aufspürens der Bedeutung dieser Namen wurde von einigen Interpreten Pynchons angenommen. Es zeigt sich aber, dass ,most of the often ludicrously overdetermined names,

\footnotetext{
${ }^{244}$ Hanjo Berressem, Pynchon's Poetics Interfacing Theory and Text, Urbana and Chicago 1993, S. 95.

${ }^{245}$ Ebd., S. 96.

${ }^{246}$ Peter Freese, From Apocalypse to entropy and beyond: The second law of thermodynamics in Post-War American Fiction, S. 501.
} 
[...] both promise and deny meaning." ${ }^{247}$ Lisa Saariluoma sieht in den merkwürdigen Namen den ersten Irritationsmoment in $C L$ 49: „Mit den wunderlichen, über das Normale und Glaubwürdige weit hinausgehenden Namen stört Pynchon gleich zu Anfang den Prozess, in dem der an die Konventionen des realistischen Romans gewohnte Leser sich bemüht, um den Namen herum einen wirklichkeitsnahen, ,runden“ Charakter zu gestalten. ${ }^{\text {‘248 }}$ Eine besondere Aufmerksamkeit wird natürlich dem Namen Oedipa geschenkt. Es wird nach Parallelen in der griechischen Tragödie König Ödipus und bei Freudscher Auslegung des Ödipus-Komplexes gesucht, die sich jedoch sehr beschränkt als zufriedenstellend erwiesen. Der Name der Protagonistin bleibt somit ein ,Ort der Instabilität ${ }^{\text {. }}{ }^{249}$ Entropiefördernd sind meines Erachtens jene bedeutungsverdächtigen Namen in dem Sinne, dass ihre Dechiffrierung nach zusätzlichen Informationen verlangt. Die Gewinnung der verborgenen Bedeutung der Namen wie Oedipa, Inverarity, Mucho oder Schrift bedarf einer Reihe von Zuordnungen, d.h. gewisse ,Ordnungen“ müssen erst lokalisiert werden, um jenen der zum Teil vermutete Sinn entnommen werden könnte. Die Unsicherheit angesichts der nicht eindeutig lokalisierbaren Verweise produziert mehr und mehr Spekulationen, von denen keine wahrscheinlicher als die andere erscheint. Die Anhäufung von scheinbar nützlichen Informationen führt im Endeffekt nicht - wie erwartet - zur ordnenden Differenzierung, sondern zur Entdifferenzierung.

Einen wichtigen Hinweis für die detektivische Arbeit des Lesers, der weitere camouflierte entropische Momente aufzuspüren sucht, finden wir bei Anne Mangel, die auf die Tatsache aufmerksam macht, dass Pynchons Jonglieren mit wissenschaftlichen Konzepten teilweise satirische Züge aufweist:

„His characters frequently take scientific concepts in an absurdly serious manner. Though [...] he often handles his characters' involvement with science in a loosely satirical way, the ideas from science and information theory still form the basis both for his characters' predicaments and also for Pynchon's own style of writing."250

Eine besondere Aufmerksamkeit, wie es sich zeigt, wird der Leser von $C L 49$ der Informationszirkulation und deren Kodierung im Roman widmen müssen. ${ }^{251}$ Für jeden

\footnotetext{
${ }^{247}$ Ebd., S. 502.

248 Liisa Saariluoma, Der postindividualistische Roman, Würzburg 1994, S. 153.

${ }^{249}$ Vgl. Alison T.J. Preston, Humor and Decentered Meaning in Lot 49, in: Thomas Schaub, Approaches to Teaching Pynchon's The Crying of Lot 49 and Other Works, New York 2008, S. 76.

${ }^{250}$ Anne Mangel, Maxwell's Demon, Entropy, Information: The Crying of Lot 49, in: George Levine and David Leverenz (ed.), Mindful Pleasures Essay on Thomas Pynchon, Boston, Toronto 1976, S. 95.

251 Jede Kodierung zerstört dabei Teile der virtuellen Information und macht somit die Utopie eines direkten Transfers zunichte. Vgl. Hanjo Berressem, Pynchon's Poetics Interfacing Theory and Text. Urbana, Chicago 1993, S. 100. „Transmitting all the virtual information would require overcoming the inherent structure of language itself, abolishing the workings of the signifier within the transfer of the signifier into the signified [...]"
} 
Informationstransfer wird immer irgendeine Kodierung notwendig. Werden wir uns jedoch solche ,direkte Übertragung“ vorstellen wollen, dann ,such an uncoded transfer would imply the elimination and exclusion of the system of signifiers. [...] the only possibility of such a transfer - because the subject is inevitably inscribed into the network of signifiers - would be the magic intrusion of a signified from outside the system." ${ }^{252}$ Diese besondere Wahrnehmung, dieses plötzliche, augenblickliche ,Eindringen des Metaphysischen ins Reale“ hat Oedipa im Laufe ihrer Suche mehrmals erleben können. „She could, at this stage of things, recognize signals like that, as the epileptic is said to - an odour, colour, pure piercing grace note sounding his seizure.“ $(C L 49,66)$ Trotz enormer Konzentration blieb ihr „the central truth itself, which must somehow each time be to bright for her memory to hold; which must always blaze out, destroying its own message irreversibly, living an overexposed blank when the ordinary world come back“ $(C L 49,66)$, jedoch ein Rätsel. Das Wesen ,jener zentralen Wahrheit' bleibt außersprachlich und die Sprache ist eben deswegen entropisch, da „,it makes a direct/ideal transfer impossible. “253

Wie es sich jedoch zeigt, ist/wirkt die Sprache nicht nur einfach entropisch. Ihre zwiespältige Natur bringt immer ein falsches Versprechen mit, „the paradoxical promise of a message outside language.“ ${ }^{254}$ Und wie es Zofia Kolbuszewska zutreffend schlussfolgert: „The space of the inexpressible constantly invades the space of the discourse. Nevertheless it is impossible to 'arrest' the Other as a signified." ${ }^{255}$ Um den Sinn der (möglichen) Positivität der Entropie in der Informationstheorie richtig einschätzen zu können, sollte man sich das Sender-Empfänger-Modell ${ }^{256}$ vor Augen stellen und den dazu gehörenden Begriff des ,Rauschens‘ (im Sinne der Störung) thematisieren. Das Phänomen des Rauschens dient in der Kybernetik zur Beschreibung der Verzerrung, die die Nachricht auf dem Weg vom Sender zum Empfänger stört. Die vom Empfänger rezipierte Information wird sich als Folge vom Original mehr oder weniger unterscheiden:

\footnotetext{
${ }^{252}$ Ebd., „Having recourse to a message from 'the other side', then is the only way to escape or circumvent the subversion of the signified by the signifier."

${ }^{253}$ Ebd., S. 101 ,It is always this oscillation between an investment in the process of ordering and the failure of this process that defines Oedipa's quest, the constant oscillation between language and the promise of an integral transfer of information." Ebd., S. 104.

254 Ebd., S. 105.

${ }^{255}$ Zofia Kolbuszewska, The poetics of chronotope in the novels of Thomas Pynchon. Lublin 2000, S. 90.

${ }^{256}$ „Das Sender-Empfänger-Modell definiert Kommunikation als Übertragung einer Nachricht von einem Sender zu einem Empfänger. Dazu wird die Nachricht kodiert und als Signal über einen Übertragungskanal übermittelt. Dabei kann die Nachricht durch Störungen verfälscht werden. Eine Voraussetzung für die erfolgreiche Kommunikation ist, dass Sender und Empfänger die gleiche Kodierung für die Nachricht verwenden." http://de.wikipedia.org/wiki/Sender-Empf\%C3\%A4nger-Modell (Stand: Sept. 2013)
} 
„Das Rauschen im Kanal ersetzt einen bestimmten Teil der Struktur der Zeichenkombination durch Zufallselemente. Je höher das Rauschen, desto unstrukturierter die Zeichenkombination und folglich desto schwieriger ist sie vom Empfänger zu decodieren.“ [...] „Unter Rauschen verstehen wir all jene Elemente, die mit dem Signal einer Nachricht interferieren. [...] Es ist daher in der Regel unerwünscht, weil es nie ein Teil der ursprünglich abgesendeten Nachricht ist. [...] Ist der Rauschanteil einer Nachricht aber zu hoch, kann sie nicht decodiert werden.“ 257

Picicci stellt die These auf, dass das Erscheinen des Rauschens in der Kultur der Informationsgesellschaft auf kulturell unzugängliche Bereiche verweise: „Je mehr etwas rauscht, desto weniger verfügt die Gesellschaft über den Code, um die Nachricht zu verstehen.“ ${ }^{258}$ Dabei sollte jedoch beachtet werden, dass keinem Signal nur ein einziger, spezifischer Code entspreche, der die Dechiffrierung der Nachricht garantieren würde, denn „selbst der Code liefert lediglich das Instrumentarium, durch das ein Signal erst zum Signal wird.“259 Picicci scheint einen interessanten Aspekt zu beleuchten, indem er das mit Hilfe des Begriffs des Rauschens ausgedrückte Unvermögen als ein in die Kultur zurückfließendes ästhetisiertes Signal thematisiert. Es bleibt zu fragen, wem solche ästhetische Inszenierung des kulturellen Rauschens dient. Wird dadurch die Kommunikation reibungsloser oder wird nur die Distanz zwischen der Nachricht und dem Rauschen größer, „so, dass das Rauschen unverändert die Chiffre für das Ausgeschlossene, die ewige Projektionsfläche für das Andere, das Irrationale, das Chaotische bleibt?“ ${ }^{260}$ Eher verwirrend wirkt dagegen im Kontext von $C L$ 49 Piciccis Behauptung „Entropie, Rauschen und Störung lassen sich weitgehend als identisch betrachten"261, da Rauschen wie Entropie im kommunikationstheoretischen Kontext Chaos, Strukturlosigkeit und Unordnung bezeichnet und im Kanal die Nachricht stört. Solche Gleichstellung von inkompatiblen Begriffen erschwert meines Erachtens u. a. ein erfolgreiches Aufspüren und Interpretation expliziter und impliziter Darstellung der Entropie im Roman. Eine nützliche Unterscheidung liefert Picicci dagegen, indem er auf zwei Typen kulturellen Rauschens aufmerksam macht:

„Der eine resultiert aus der zu geringen Strukturierung des Codes, der andere aus einer zu großen. Wo in einem Fall das Rauschen aus der entropischen Gleichverteilung erwächst, entsteht sie im zweiten Fall aus der Konzentration von Redundanz. Will man beide Arten des

\footnotetext{
${ }^{257}$ Annibale Picicci, Noise Culture. Kultur und Ästhetik des Rauschens in der Informationsgesellschaft am Beispiel von Thomas Pynchon und Don DeLillo, Berlin 2001, S. 9ff. (Der Code wird hier im semiotischen Sinne nach Eco, sowohl als syntaktische als auch als semantische Regel verstanden.)

${ }^{258}$ Ebd., S. 8.

259 Ebd.

260 Ebd.

${ }^{261}$ Ebd., S. 14.
} 
Rauschens den Kategorien Ordnung und Unordnung zuschreiben, so könnte man sagen, die erste Variante bedeutet Unordnung und Chaos, die zweite Ordnung und Redundanz. Doch in beiden Fällen ist das Resultat gleich: Bedeutungslosigkeit.،262

Abgesehen davon - wie bereits oben angemerkt - dass das Einflechten der Entropie in die Logik des Rauschens eher verwirrend wirkt, scheint diese Unterscheidung auf CL 49 gut applizierbar zu sein. Tatsächlich könnte man zweierlei Störung im Kanal der Kommunikation, die Oedipa zu bewältigen sucht, finden: Manches Stören weist eine sehr geringe Strukturierung (des Codes) auf, wie z.B. der bereits erwähnte Druckfehler auf dem Briefumschlag von Mucho, das andere dagegen wird durch eine große Komplexität gekennzeichnet, wie Tristero selber. Falsch ist jedoch meines Erachtens Piciccis Fazit, indem er der beiden Rauschentypen Bedeutungslosigkeit als Resultat ihres Wirkens zuschreibe. ${ }^{263}$ Sehr wohl bedeutet die verzerrte Nachricht etwas, so, wie das im permanenten Rauschen erscheinende Tristero irgendwelche Bedeutung hat.

Eine der überraschendsten Situationen, in der das Rauschen in CL 49 zum Ausdruck kommt, ist ohne Zweifel das kurze Interview mit Oedipa, geführt von ihrem Mann Mucho für seinen Radiosender KCUF, nachdem Dr. Hilarius (Oedipas Psychoanalytiker) verrückt geworden war und sich mit einem Gewehr in seiner Klinik einsperrte. Oedipa, die Zeugin des Vorfalls war und auch die letzte Person, die sich mit Hilarius vor seiner Festnahme unterhielt, wurde gebeten, einen Bericht für KCUF abzugeben:

„'How do you feel about this terrible thing?' 'Terrible', said Oedipa. 'Wunderful', said Mucho. He had her go on to give listeners a summary of what'd happend in the office. 'Thank you, Mrs Edna Mosh', he wrapped up, 'for your eyewitness account of this drama siege at the Hilarius Psychiatric Clinic. [...] 'Edna Mosh?' Oedipa said. 'It'll come out the right way', Mucho said. 'I was allowing for the distortion on these rigs, and then when they put it on tape. "“ ( $C L 49$, $96)^{264}$

Im Gegensatz zu Oedipa scheint Mucho mit dem Phänomen des Rauschens vertraut zu sein, er kennt den Mechanismus seines Funktionierens und weiß somit Verzerrungen zu bewältigen, indem er durch gezielte verbale Manipulation die Störung im Kanal austricksen

\footnotetext{
${ }^{262}$ Ebd., S. 38.

${ }^{263}$ Ich vermute, dass Picicci die Bedeutungslosigkeit des Rauschens im Kontext seines Vermengens mit dem Signal versteht. Das Rauschen an sich, abgesehen vom Signal lässt sich meines Erachtens gar nicht fassen.

${ }^{264}$ Freese situiert die Szene im Kontext des Problems der allmählichen Auflösung der Identität und der Individualität der Protagonistin, die letztlich in ihre Unfähigkeit zur Kommunikation mündet. S. Peter Freese, From Apocalypse to entropy and beyond: The second law of thermodynamics in Post-War American Fiction, S. 548.
} 
kann. Diese Szene kann darüber hinaus selbst als eine parodistische Verzerrung der Idee des Rauschens gedeutet werden. Nimmt man das Sender-Empfänger-Modell als Vorbild, wird die originelle Nachricht erst im Kanal, auf dem Weg vom Sender zum Empfänger durch das Rauschen verzerrt. Mucho als Sender weiß, dass, wenn er den Namen Oedipa Mass richtig ausspricht, wird der Name in Folge einer Verzerrung im Kanal beim Empfänger verändert ankommen wird. Bewusst sendet er den von sich selbst verzerrten Namen in den Kanal mit der Gewissheit, dass der Name nach der nächsten Verzerrung so wahrgenommen wird, wie er richtig ist. Die kurze Szene ist also, meiner Meinung nach, eine Parodie des gesamten Konzeptes des Rauschens und folglich der Versuche, durch gezieltes, verbales Manipulieren, in die im Kanal gestörten Nachrichten ,Ordnung ${ }^{6}$ zu bringen. Muchos Trick, obwohl er Züge eines absurden Spiels verrät, thematisiert indirekt neue, bisher ungeahnte Mechanismen der postmodernen zwischenmenschlichen Kommunikation. Pynchons Leser im 21. Jahrhundert werden vielleicht die Szene im Kontext der Komplexität der digitalen Medienlandschaft situieren wollen, um in dieser Umwelt neue Bereiche $\mathrm{zu}$ entdecken. Die Störung der Kommunikation zwischen den Figuren in $C L 49$ führt oft zur Verwirrung während der Lektüre, denn

,the transmission of information through language paradoxically results in 'massive destructions of information'. The notion that information may be conveyed through linguistic symbols and codes is repeatedly shattered in the novel. Symbols and codes simply contribute to the chaos and lack of information."265

Das von Oedipa in der Bar Scope entdeckte Symbol des gedämpften Posthorns assoziiert sie zunächst nur mit WASTE. Mit der Zeit wird es allmählich zu einem ,all inclusive sign’: „It appears not only with WASTE, Oedipa discovers, but along with the etching DEATH on the back of a bus seat, and with an invitation to join the AC-DC, the Alameda County Death Cult. Such symbols continually seduce by suggesting information and meaning, yet they never reveal it." ${ }^{266}$ Wenn Wörter wie waste oder death zugleich noch zu Akronymen werden: W.A.S.T.E. (We Await Silent Tristero's Empire) und D.E.A.T.H. (Don't Ever Antagonize The Horn) bedeuten, und Namen, wie KCUF an ein provozierendes Anagramm denken lassen, wird die Konstruktion von stabiler Bedeutung zur enormen Herausforderung.

Einer tieferen Überlegung bedarf des Weiteren die Bestimmung des ontologischen Status‘ des Rauschens, das von Tristero produziert wird. Picicci betont, dass es „keineswegs

\footnotetext{
${ }^{265}$ Anne Mangel, a.a.O., S. 97.

${ }^{266}$ Ebd.
} 
metaphysischer Natur, sondern eindeutig Bestandteil physischer Realität“ ${ }^{267}$ sei. Diese These weiß Picicci jedoch nicht zu begründen und unklar bleibt auch, was die ,Übernatürlichkeit‘ des Tristero-Rauschens bedeuten solle, die Picicci Oedipas Wahrnehmung(sdeutung) zuschreibt. Im weiteren Teil seiner Arbeit verwirrt Picicci noch einmal, indem er das Rauschen in den semiotisch-kulturellen Kontext stellt, es als all das definiert „was einer postulierten eigentlichen Nachricht im Weg steht, mit ihr interferiert," und durch die Erweiterung dieser Metaphorik, all die Elemente miterfassen will, „die mit einem reibungslosen und normierten Kommunikationsfluss interferieren. “ 268 Aufgrund des so definierten Rauschens deutet es Picicci als „Chiffre für die Ausgestoßenen und die Entrechteten, die Ausgeschlossenen der Gesellschaft, die an keinem der kulturellen

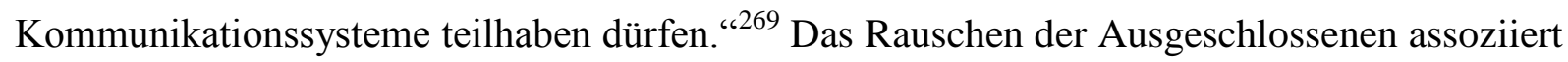
er dann mit den parasitären Beziehungen in der sozialen Kommunikationsstruktur: „Das Rauschen wird mit dem Parasiten identifiziert, der seinen Wirt ausbeutet.“270 Sollten wir uns das offizielle Kommunikationssystem, oder genauer noch den offiziellen Kommunikationsfluss als eben diesen Wirt vorstellen, bleibt es völlig unklar, wie eigentlich die Ausbeutung durch die Ausgestoßenen zu verstehen sei. Das Problem der wenig explikativen Analysen Piciccis scheint meines Erachtens im Grunde darauf zu beruhen, dass er mit Begriffen wie Rauschen und Entropie jongliert, ohne in die Tiefe ihrer möglichen Implikationen eindringen $\mathrm{zu}$ wollen. Als kaum einleuchtend müssen dann seine Ausführungen erscheinen, wenn er unsicher das Tristero tastet und sich nicht entscheiden kann, ob es entropische oder eher negentropische Arbeit leistet. ${ }^{271}$

Die Schwierigkeit einer plausiblen Verbindung des Tristero mit der Entropie resultiert aus der Tatsache, dass es „often mistaken for the embodiment of maximum entropy as understood negatively ${ }^{6272}$ interpretiert wird. Freese betont, dass hier das Gegenteil der Fall sei. Die illusionslosen Mitglieder des Tristero haben ein Kommunikationssystem geschaffen, das eine Reihe von unerwarteten und informativen Bedeutungen übertrage. So gesehen, „the allusive, ambiguous and charged signs of the Tristero are unpredictable, unexpected, highly informative and thus negentropic. Far from being a symptom of the dissipation of energy,

\footnotetext{
${ }^{267}$ Annibale, Picicci, a.a.O., S. 44.

${ }^{268}$ Ebd., S. 45.

269 Ebd.

${ }^{270}$ Ebd., S. 46.

${ }^{271}$ Ebd., S. 47

272 Peter Freese, From Apocalypse to entropy and beyond: The second law of thermodynamics in Post-War American Fiction, Essen 1997, S. 549. Freese führt hier Beispiele definitiv falscher Interpretationen des Tristero, die aus dem falschen Verständnis des Phänomens der Entropie resultieren an.
} 
then, the Tristero should be understood as a promising sign of renewal and reordering." Freese unterscheidet drei Ebenen, auf denen das geheime System in verschiedenen Rollen auftritt:

"On the level of the quest-romance, the Tristero functions as the pentecostal 'other", as the mysterious realm from which the desired revelation might emanate and which might provide the sought-for 'miracle' by means of 'another world's intrusion into this one'. On the level of the socio-critical exposition of the Californian wasteland, the Tristero functions as 'the separate, silent, unsuspected world' of the downtrodden and disinherited rejected by the ruling system and as the potential counter-force of 'the other America' which possesses an enormous revolutionary power and might bring back the lost diversity of California's days and thus redeem the neon-lit wasteland of Oedipa's time. On the cybernetic level, finally, the Tristero can be understood as one of those anti-entropic enclaves which Norbert Wiener speaks about, that is, as a 'local and temporary island of decreasing entropy in a world in which the entropy as a whole tends to increase.",274

Diese detaillierte Auflistung der möglichen Deutungsweisen von Tristero, inklusive seiner Beziehungsvarianten zur Entropie, zeigt deutlich, wie viel Fingerspitzengefühl und interdisziplinäre Kompetenz man an den Roman Pynchons heranbringen muss, um den verwirrenden Text halbwegs einleuchtend interpretieren zu können. Zur wirklichen Herausforderung sowohl für die spontane Lektüre als auch für die literaturwissenschaftliche Zwecke wird, was ich zu zeigen versuchte, der Nuancenreichtum möglicher Lesarten, der sich in literarästhetischen Inszenierungen von solch komplexen Phänomenen wie Entropie oder Rauschen entfalten mag. Eine präzise Untersuchung jener primär der Geisteswissenschaften fremden Erscheinungen hilft ohne Zweifel, die direkten Ursachen der Verwirrung auf Seiten des Lesers zu bestimmen, lässt den Grad ihrer Verdichtung und Anhäufung einschätzen und Momente der Lektüre lokalisieren, an denen der Leser höchstwahrscheinlich den Zustand der völligen Desorientierung erreichen wird. Die ersten Fallen, die schnell auf interpretatorische Irrwege führen, betreffen, wie bereits erwähnt, die klare Bestimmung der Begriffe wie ,Ordnung' und ,Unordnung'. Zusammenfassend muss sich der Pynchon-Leser darüber im Klaren sein, dass ,Unordnung“ „nicht die Abwesenheit von Ordnung [sei], sondern ein Zusammenprall beziehungsloser Einzelordnungen. “275 So viel besagt nämlich ein vertieftes Verständnis der Erscheinung der Entropie, die allzu schnell fälschlicherweise mit dem Prozess der Entdifferenzierung assoziiert wird. In ihren Analysen von Gravity`s Rainbow,

\footnotetext{
${ }^{273}$ Ebd., S. 550.

${ }^{274}$ Ebd., Das Zitat von Wiener, a.a.O., S. 52.

${ }^{275}$ Rudolf Arnheim, a.a.O., S. 23.
} 
dem größten und kompliziertesten Roman Pynchons, versucht Gabriele Schwab, „Entropie und Negentropie nicht als binäre Oppositionen, sondern als komplementäre Vorgänge in systemischen Entwicklungsprozessen“276 zu deuten. Das Romangeschehen als Resultat der spezifischen (manipulierten) Dialektik der Differenzierung und Entdifferenzierung zu lesen, lässt in den Zu- und Abnahmen der Entropie „Reservoir möglicher Neudifferenzierungen“‘277 situieren. Die allmähliche Entdifferenzierung sorgt für die Steigerung der Verwirrung, da in ihrem Verlauf orientierungsgebende, ordnende Hierarchien verdünnt, gelockert und bis zur Auflösung gebracht werden. Mit diesem Mechanismus ist meines Erachtens das gesamte Romangeschehen von $C L 49$ durchtränkt, keine der dargestellten Sicht(weisen) gewinnt nämlich das Privileg, relevanter als andere zu sein, Schablonenhaftigkeit der Figuren und der Entzug ihrer psychologischen Dimension lassen keine großen Unterschiede zwischen ihnen feststellen, die ihre Rolle für Oedipas Aufgabe einschätzen ließen. Ein gewisser Zuwachs an Entdifferenzierung kann letztlich ein paranoides Verhalten hervorrufen. Hoffmann sieht in der ,operationalen“ Paranoia „eine Art Umgangs mit einem entropischen Universum, das nicht als neutral, ohne Sinn und Bedeutung vorgestellt werden kann, ohne dass der Mensch in seinem Wesen, das auf Sinn angewiesen ist, gefährdet wird. ${ }^{278}$ Im Falle Oedipas würde ich aber ihre Paranoia eher als Folge der Entropiezunahme sehen und so gesehen, kann diese zunächst schlecht als Erkenntnisstrategie eingesetzt und erprobt werden. Sehr wohl aber könnte die Paranoia nicht nur im Sinne des ,reinen Wahnverhaltens ‘ begriffen werden und ,nicht mehr aus dem Gegensatz zur symbolischen Ordnung [...], sondern als Überanpassung an sie. [...] Die gegen die Systemparanoia gerichtete ,kreative Paranoia' kann dann wie ein

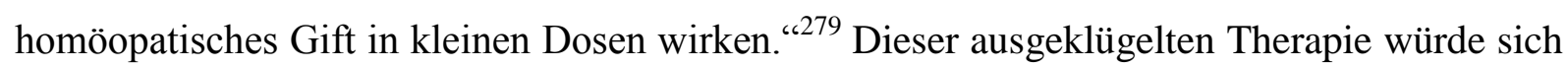
Oedipa angesichts ihrer geistigen Verwirrtheit zweifelsohne unterziehen wollen, denn die darauf vorbereitende Ahnung, das „sinnkonstituierende Erleben, das die Paranoia seiner Figuren hervorbringt, [...] dem Abweisen einer unerträglichen Realität “280 diene, scheint sie bereits erfahren zu haben. Ein Übergang von der Diagnose der klinischen Paranoia zur strategisch-therapeutischen Applikation dieser in der Form ihrer kreativen Modifizierung,

\footnotetext{
${ }^{276}$ Gabriele Schwab, a.a.O., S. 230.

277 Ebd.

${ }^{278}$ Gerhard Hoffmann, Das narrative System der Postmoderne und die Auflösung des Charakters im Erzähltext: Die Reduktionsformen von Handeln und Bewußtsein, in: Gerhard Hoffmann (Hg.), Der zeitgenössische amerikanische Roman: Von der Moderne zur Postmoderne, Bd. 1, Elemente und Perspektiven, München 1988, S. 199.

${ }^{279}$ Gabriela Schwab, a.a.O., S. 210.

${ }^{280}$ Ebd., S. 211.
} 
bedarf jedoch einer Phase der vertieften antizipierend-sortierenden Reflexion, die Oedipa meines Erachtens (noch) nicht erreicht hat. 


\subsection{Entropische Desorientierung}

Schon die ersten Seiten von Pynchons CL 49 lassen den Leser im Text typische Merkmale eines Detektivromans erkennen: die Protagonistin scheint mit einer klar formulierten Aufgabe konfrontiert $\mathrm{zu}$ sein, die sich schnell als ein zu lösendes Rätsel entpuppt, die Ermittlungen, die zur Lösung des Rätsels führen sollen, bedürfen einer Reihe von durchdacht geplanten Schritten und auf dem Weg zur erfolgreichen Enthüllung des Geheimnisses lauern auf die Ermittlerin Gefahren, falsche Spuren zu verfolgen und durch falsches Deuten von Indizien Irrwege zu betreten, die die Ermittlung zu zahlreichen Sackgassen führen werden. Nicht allzu schnell wird dem Leser klar, dass seine der Spezifik der Detektivromane entnommenen Erwartungen konsequent enttäuscht werden, dass es hier nämlich keine Lösung des Rätsels in Sicht ist. Diese in der Makroperspektive der Lektüre wahrgenommene Irritation wird dem Leser das Aktivieren gesteigerter Wachsamkeit und Aufmerksamkeit abverlangen, da sich die aufrechterhaltende Unmöglichkeit der Sinnstiftung ihn zunehmend obsessiv an mögliches Übersehen der für die Bedeutungshervorbringung relevanter Geschehensmomente denken lässt. Die großkalibrigeren Strategien der Verwirrung in $C L 49$ sind meines Erachtens grob genommen epistemologisch und ontologisch fundiert, d.h. sie betreffen sowohl die Fragen der Erkenntnis der Phänomene als auch die Art, wie diese im Geschehen des Romans existieren. Die Verwirrung (auf) der ontologischen Ebene betrifft das, was Brian McHale „hesitation between alternative worlds (levels of reality, orders of being)“6281 nennt. Das größte Dilemma hier resultiert aus der Unmöglichkeit des Bestimmens, welcher Art Entität das geheime System Tristero sei. Im Laufe ihrer Suche wurde Oedipa mit mehreren Existenzweisen von Tristero konfrontiert und ,je mehr aber Tristero bedeuten könnte - und er scheint am Ende vielen Interpretationen offen -, desto wahrscheinlicher wird es, dass er vielleicht auch nichts bedeutet und Rätselhaftigkeit sein eigentlicher Inhalt ist.“282 ,Ontological hesitation“ des Tristero konnte nicht mal innerhalb des Spiels The Courier's Tragedy vermieden werden. In den unterschiedlichen Versionen des Spiels machte „this constantly shifting signifying chain [...] indeed impossible to 'pin a signifier to a

\footnotetext{
${ }^{281}$ Brian McHale, Constructing Postmodernism, London, New York, 1992, S. 208. McHale behauptet, die ontologische Störung markiere eine neue Qualität des Schreibens: „When ontological doubt, uncertainty about what is (fictively) real and what fantastic, insinuates itself into a modernist text, we might well prefer to consider this the leading edge of a new mode of fiction, an anticipation of postmodernism. S. 65.

${ }^{282}$ Heinz Ickstadt (Hg.), Ordnung und Entropie. Zum Romanwerk von Thomas Pynchon, Reinbek bei Hamburg 1981, S. 113.
} 
signified.“،283 Diese Strategie, die in Pynchons Texten so oft Einsatz findet, dieses Zuviel an Zeichen und Namen, das man als eine regelrechte Signifikantenüberflutung beschreiben kann, konfrontiert den Leser mit einem Zuviel an (möglichen) Bedeutungen. Das Tristero zum Beispiel „verweist auf sein immenses semantisches Potential, dessen Möglichkeitshorizont an Signifikaten völlig unkontrolliert wuchern kann. ${ }^{\text {“284 }}$ Dabei bleibt nicht nur sein ontologischer Status unklar, es lässt sich auch nicht mit Sicherheit feststellen, ob es eine positive oder negative Entität sei: „Das Tristero-System in Lot 49 versinnbildlicht die ambivalente Diskrepanz zwischen einer neuen, konstruktiven Kraft einer noch unbenennbaren Ordnung und der destruktiven Kraft gegenüber dem etablierten semiotischen Regelwerk in dem sie wirkt. ${ }^{\text {‘285 }}$

Wesentlich komplexere und tiefere Verwirrungen als die der ontologischen Ebene bewirkt jedoch die Epistemologie von $C L$ 49. Eine gezielte Untersuchung der epistemologischen Positionen der Protagonistin lässt, wie ich meine, drei unterschiedliche Erkenntniswege aussortieren. Der erste und sicherste Weg sollte durch minutiöse, linear strukturierte Recherche im Text führen. Oedipa scheint zunächst davon überzeugt zu sein, dass die einzige stabile Erkenntnis, d.h. der Gewinn der Bedeutung, nur diskursiv ${ }^{286}$ möglich sei. Ihre mühsame Suche und Analyse der sich unterscheidenden Textstellen von The Courier's tragedy, ihr Interesse für die Geschichte der Briefmarken Inveraritys und für die Hintergründe der Entstehung der Wohnsiedlung Fangoso Lagoons zeugen davon, dass es eben der diskursive Erkenntnisweg ist, an dessen Erfolg Oedipa trotz des wiederholten Scheiterns bis zu Ende glaubt.

Die erste Erfahrung der Offenbarung im Sinne einer nicht-diskursiven, d.h. rational plausibilisierbaren Erkenntnisvariante, sucht Oedipa in Form einer Wahrnehmung heim, die die Existenz einer anderen Erkenntnisfrequenz ankündigt. ${ }^{287}$ Die Gefühle, die die Erfahrung dieser Art hervorrief, blieben jedoch ambivalent und ließen den Zustand einer Hellhörigkeit entstehen, der jedoch ohne den Willen zur radikalen Umstellung der epistemologischen Einstellung zur Enttäuschung und Isolation führen muss: „,...] this tantalizing web of partial revelation, $[\ldots]$ inveigle the reader into mimicking solipsistic and paranoid protagonists who isolate themselves even more profoundly in the course of their epistemological quests.“ ${ }^{\text {‘288 }}$

\footnotetext{
283 Hanjo Berressem, a.a.O., S. 97.

${ }^{284}$ Annibale Picicci, a.a.O., S. 96.

${ }^{285}$ Ebd, S. 69.

${ }^{286}$ Siehe: Fn. 3, S. 3.

287 Siehe das Zitat S. 41f.

${ }^{288}$ Peter L. Cooper, Signs and Symptoms, Berkeley, Los Angeles, London 1983, S. 40.
} 
Wie wäre also die Erkenntnisbilanz Oedipas am Ende ihrer Queste zu deuten? Hat sie die durch ihre Ambivalenz enttäuschende - Erfahrung der Hierophanien auf irgendwelche Art und Weise bereichert und wäre es eine schützende „Verstrickung in die Labyrinthe subjektiver Projektion““289? Diese Möglichkeit, die erkenntnistechnisch der Paranoia nahe liegt, bleibt jedoch eine stets unsichere und ,however conscious she becomes of her possible instability, Oedipa seems to have only marginal insight into why she might project fantasies." ${ }^{290}$ Ickstadt situiert daher vorsichtig die Protagonistin von CL 49 ,drinnen wie auch draußen, an der Schwelle einer Offenbarung von Totalität.“ ${ }^{291}$ Sollte sie sich „Zwischen Fiktion als paranoiden Gewissheit und einem Nichts an Sinn“ entscheiden, so würde sie „Fiktionen von Sinn im Bewusstsein ihrer möglichen Nichtigkeit“6292 wählen.

Die permanente Instabilität des ontologischen Status' des Tristero und die wachsende Unsicherheit, welcher Erkenntnisweg tatsächlich zu seinem Geheimnis führt, bilden meines Erachtens die wichtigsten, zur Desorientierung führenden Momente in $C L$ 49. Die von Pynchon erprobten Textstrategien, die sich hinter diesem Effekt bergen, lassen sich - wie ich zu zeigen versuchte - mit dem Phänomen der Entropie einleuchtend beschreiben, das die Mechanismen der Entdifferenzierung, des Rauschens und folglich des Sinnentzugs in sich vereint. Auf höchst ausgeklügelte Art und Weise jongliert Pynchon in CL 49 mit Zeichen, indem er diese einführt und bald verschwinden lässt, bevor ihnen ein Minimum an Bedeutung entnommen werden kann, und es ist meines Erachtens eben das Fehlen dieses Minimums, dass den Leser konsequent daran hindert, die ihn überflutenden Informationen und Ereignisse sinnhaft miteinander verknüpfen zu können. Die Handlung scheint somit, wie es Baran treffend auf den Punkt bringt, ihren Höhepunkt in Entropie zu erreichen - „der perfekten Ordnung des völligen Widersinns. ‘293

Der desorientierte Leser findet sich am Ende der Lektüre mit dem Dilemma konfrontiert, inwieweit sich noch aus der Menge der von der Protagonistin gefundenen Spuren Bedeutung des ganzen Romangeschehens herauspräparieren lässt. Seine mentale Arbeit ähnelt dann sozusagen einer Verhandlung des Sinns. ${ }^{294}$ Der Ausweg aus der Desorientierung muss

\footnotetext{
${ }^{289}$ Heinz Ickstadt, a.a.O., S. $118 \mathrm{f}$.

290 Peter L. Cooper, a.a.O., S. 147

${ }^{291}$ Heinz Ickstadt, a.a.O., S. 122.

292 Ebd.

293 Bogdan Baran, Postmodernizm i końce wieku [Der Postmodernismus und die Enden des Jahrhunderts], Krakòw 2003, S. 169. [„doskonałym porządku zupełnego absurdu.] Baran bemerkt dabei, dass „'Entropie’ die post-moderne Entsprechung der traditionellen Kulmination des dramatischen Fadens" sei. [„,'Entropia' [...] stanowi post-moderny odpowiednik tradycyjnej kulminacji dramatycznego watku."]

${ }^{294}$ Vgl. Dorota Korwin-Piotrowska, Powiedzieć świat. Kognitywna analiza tekstów literackich na przykładach [Die Welt sagen. Kognitive Analyse literarischer Texte mit Beispielen], Kraków 2006, S. 97. Zum Wesen der
} 
zwangsläufig über Kompromisse führen, in denen man auf Eindeutigkeit, Klarheit und Stabilität der Bedeutung des Textes verzichten muss und die Wahrscheinlichkeit mehrerer möglicher Deutungen in Betracht zieht. CL 49, wie auch andere Romane Pynchons, führen die Leser allzu gern zu interpretatorischen Sackgassen und versetzen sie in den Zustand des permanenten Zweifels an der Überzeugungskraft ihrer provisorisch konstruierten Deutungen.

Wie bereits erwähnt, habe ich $C L 49$ als ein Beispiel einer sich erst konstituierenden literarischen Postmoderne eingestuft. Eine dynamisch (kreierte und konstant) zunehmende Ambivalenz wird m.E. zum Hauptcharakteristikum dieses Romans. „Das Bewusstsein von der Austauschbarkeit [...] der Werte, Regungen, Handlungen, Aussagen“ “295 wird somit zur wichtigsten Entdeckung, die der Rezipient von CL 49 während oder am Ende der Lektüre gewinnen wird. Diese in erster Linie durch das enthierarchisierte Informationsüberangebot entstandene Ambivalenz möchte den Leser herausfordern, ihm eine neue Art der Lektüre erzwingen ${ }^{296}$, ihn an ein (neuartiges) „multiples, ästhetisches Entkodieren denken lassen.“297 Die ambivalente Situation Oedipas, begriffen „als Zusammenwirken einander entgegengesetzter Regungen““298 sollte den Leser auch an mögliche Konsequenzen solcher ambivalenten Lage erinnern, nämlich an Paranoia. $\mathrm{Zu}$ den die Ambivalenz stiftenden Strategien gehören in CL 49 auch die Affirmation der Oberfläche und das Thematisieren des Undarstellbaren. „Das Hervortreten [...] einer neuen Oberflächlichkeit im wortwörtlichen Sinne ${ }^{6299}$ wird im Pynchons Roman besonders deutlich in der Szene sichtbar (wahrnehmbar), in der Oedipa einen sich aus den Buchstabenverschiebung ergebenden Druckfehler auf dem Umschlag des Briefes bemerkt. ${ }^{300}$ Eine trickreiche Verschiebung der Aufmerksamkeit des Lesers auf die Textoberfläche wird desweiteren durch das Einführen der seltsamen Namen der Figuren provoziert. Eine Art literarästhetische Krönung dieses Verfahrens bildet meiner Meinung nach der auf der letzten Seite rezipierte Teil des Satzes: „[...] was all Schrift would tell her.“ ( $C L 49,126)$ Die letzte wichtige Information im Roman erfährt Oedipa also von einem Herrn Schrift, und es war auch nicht viel, was ihr Schrift sagen konnte. Wenn aber Schrift - im Sinne von einer Reihe von Zeichen gedacht - nicht viel sagen, d.h.

\footnotetext{
sprachlichen Kommunikation gehört, dass sie in sich sowohl die Möglichkeit der Verständigung als auch die Unzulänglichkeit trägt. Der Prozess des Kommunizierens könnte man daher als Verhandlungen des Sinns verstehen. Solche Verhandlungen zielen generell auf einen Konsens ab. Vgl. ebd.

295 Peter Zima, Moderne/Postmoderne: Gesellschaft, Philosophie, Literatur. Tübingen Basel 1997, S. $254 \mathrm{f}$.

${ }^{296}$ Vgl. die Zitate von Christoph Bode auf S. 34 und von Elisabeth Neureuter auf S. 49.

${ }^{297}$ Christoph Bode, Ästhetik der Ambiguität : zu Funktion und Bedeutung von Mehrdeutigkeit in der Literatur der Moderne, Niemeyer Tübingen 1988, S. 290.

${ }^{298}$ Peter Zima, a.a.O., S. 303.

${ }^{299}$ Andreas Huyssen, Postmoderne - eine amerikanische Internationale, in: Andreas Huyssen, Klaus R. Scherpe (Hg.), Postmoderne. Zeichen eines kulturellen Wandels, Reinbek bei Hamburg 1986, S. 54.

${ }^{300}$ Siehe meine Analyse der Szene auf S. 73.
} 
kommunizieren, d.h. bedeuten kann, dann sind wir (mit Oedipa) an den Punkt gelangt, an dem uns jede Bedeutungstiefe entzogen wurde, dann sind wir in der Postmoderne angekommen. 


\section{Hyper-Subversive Desorientierung in Elfriede Jelineks Lust}

\subsection{Subversion an der Oberfläche des Textes}

Es gibt in der zeitgenössischen deutschsprachigen Literatur kaum AutorInnen, deren Werke ihre Leserschaft - sowohl die akademische als auch die unprofessionelle - so extrem polarisieren vermochten wie die Romane der Österreicherin Elfriede Jelinek. Von Kommentaren voller Ekel und schockartiger Verwerfung, über Skepsis und Irritation angesichts der schwer formulierbaren ästhetischen Qualitäten der literarischen Texte dieser Autorin bis zur affirmierenden Begeisterung der Anhänger der literarischen Experimente scheinen die Reaktionen der Rezipienten dieser originellen Schriftstellerin auf das Hervorbringen eines kulturellen Phänomens hinzuweisen, dessen künstlerischer Wert unglaublich schwierig einzuschätzen ist. Die Herausforderung, zu der die Lektüre der österreichischen Nobelpreisträgerin wird, betrifft im gleichen Maße die erzählerische Gestaltung ihrer Prosa als auch die Konfrontation mit „mikrosoziologischen Studien menschlicher Zerstörungen“ “301, deren Darstellung Jelinek auf eine meist ausgesprochen krasse und brutale Art und Weise betreibt. Als ein Musterbeispiel einer Prosa, die den Leser verschiedenartig irritiert und folglich desorientiert, möchte ich Elfriede Jelineks Roman Lust untersuchen. Der Untersuchung liegt die Behauptung zugrunde, dieser - bis jetzt krasseste Roman Jelineks sei spezifisch, neuartig subversiv. Das Novum dieser Hyper-Subversivität, wie ich sie bezeichnen möchte, besteht darin, dass sich in dem literarischen Versuch, „den Blick auf das Obszöne [...] aus weiblicher Sicht zu zeigen“ unterlaufend konfligierende Momente entfalten, deren Lektüre in die Desorientierung mündet. Der Grund dafür, so meine These, ist die Aktivierung des Subversiven an der postulierten diskursiv kommunizierbaren Schnittstelle zwischen dem Männlichen und dem Weiblichen, an der Schnittstelle, die es eigentlich nicht geben kann oder die zumindest nicht darstellbar ist. Es wäre daher eine Schnittstelle, die man/frau gerne hätte, die Lust ohne Erfolg hervorzubringen sucht und die vielleicht zu einer eingebildeten Schnittstelle, zu einer Illusion wird, die jedoch dabei mitnichten ihr Desorientierungspotential verliert. Meine Untersuchung versteht sich in diesem Sinne als ein Versuch des Aufspürens des spezifisch weiblichen Schreibens. Mein Interesse am weiblichen Literarästhetischen gilt vor allem der subversiven Wirkung, die diese Ästhetik

\footnotetext{
${ }^{301}$ Rudolf Burger, Der böse Blick der Elfriede Jelinek, in: Christa Gürtler (Hg.): Gegen den schönen Schein. Texte zu Elfriede Jelinek, Frankfurt (Main) 1990, S. 20.
} 
entfalten müsste. Mein Ziel ist, die subversiven Momente zu lokalisieren, ihren destruktiven Effekt auf den Text und auf den männlichen Diskurs einzuschätzen und das desorientierende Potential des auf diese Art und Weise de(kon)struierten Textes zu sondieren.

Das Handlungsskelett des Romans lässt sich schnell rekonstruieren: Hermann, der Papierfabrikdirektor und zugleich der größte Arbeitgeber in einem Alpenstädtchen, muss im Aidszeitalter auf den käuflichen Sex verzichten und wieder auf seine Frau Gerti zurückgreifen. Gerti versucht vergeblich, den immer brutaleren sexuellen Attacken zu entfliehen, betrinkt sich oft und unternimmt im Alkoholrausch mehrere Fluchtversuche. Gerti ist als Hausfrau von ihrem Mann finanziell abhängig, versorgt ihren Sohn, der bereits deutliche Züge Hermanns zu tragen scheint. Auf einer Flucht trifft Gerti einen gutaussehenden Touristen Michael, in den sie sich verliebt: In ihr „wird ein Quellgebiet erschlossen, von dem sie jahrelang heimlich träumte“ (L, 116), von dem sie jedoch nur verführt und bald brutal demütigt wird. Die Frau findet keine Erfüllung, wird von ihrem Mann für das Weglaufen noch brutaler und hemmungsloser vergewaltigt. Physisch und psychisch am Ende erstickt sie mit einer Plastiktüte ihren Sohn und übergibt ihn dem Wasser des Bachs.

Die Figuren in Lust sind von der Autorin psychologisch besonders arm gestaltet, sie werden eher als Schablonen ins Spiel gebracht, denn ,Jelinek zielt nicht auf die Hervorhebung individueller Schicksale ab, sie will kollektive Denk-, Sprech- und Verhaltensmuster aufzeigen. “302 Somit erkennt der Leser hier höchstens RepräsentantInnen der Geschlechtszugehörigkeit, einer gesellschaftlichen Schicht und BauchrednerInnen herrschender Diskurse ${ }^{303}$ oder weniger noch ,einige aus Sprachmüll collagierte und ideologisch zu Überlebensgröße aufgeblähte Popanze.““304 Durch dieses Verfahren wird aber die Gerti angetane Gewalt, ,,auf eine rein ,experimentelle‘ und ,artifizielle‘, kühl distanzierte und ,abstrahierte' Demonstration von Brutalität reduziert, [was] dem Leser die Möglichkeit

\footnotetext{
${ }^{302}$ Christiane Rasper, „Der Mann ist immer bereit und freut sich auf sich." Die satirische Inszenierung des pornographischen Diskurses, in: Liebes- und Lebensverhältnisse. Sexualität in der feministischen Diskussion, Frankfurt am Main/New York 1990, S. 123. Das Hauptaugenmerk schenkt Jelinek dabei der Sprachkritik, indem sie „nicht über reale Personen, sondern über Personen, wie sie sich als Sprachschablonen oder Sprachmuster materialisieren“ schreibt. (Aus einem Interview mit Elfriede Jelinek, in: Kurt Bartsch und Günther Höfler (Hg.), Elfriede Jelinek, Graz-Wien 1991, S. 13.)

${ }^{303}$ Vgl. ebd., S. 123.

${ }^{304}$ Andreas Isenschmid, Trivialer Roman in experimenteller Tarnung, in: Kurt Bartsch und Günther Höfler (Hg.), Elfriede Jelinek, Graz-Wien 1991, S. 241 „Nicht Subjekte einer Handlung, eher Akteure von Ritualen: eingesperrt in den Gefängnishof der sozialen und geschlechtlichen Rollen, drehen sie ihre immergleichen Runden und erzeugen zu Denunziationszwecken die Kollisionen des Geschlechter- und Klassenkampfs."
} 
einer sympathetischen Identifikation mit dem Opfer“" ${ }^{305}$ verwehrt oder diese zumindest erschwert.

Das Sondieren und Benennen der Verwirrungen, die Lust während der Lektüre stiftet, bedarf vor allem einer Skizzierung der Narration des Romans. Jelineks Prosa, insbesondere Lust, „,bringt keine zusammenhängende Erzählfiktion hervor, sondern erfüllt sich in einer Art diskontinuierlichen Präsentierens. “306 Der Rezeptionsakt eines solchen fragmentierten Textes „gleicht somit eher einem Nachvollziehen optischer Einstellungen“ ${ }^{307}$, bei dem sich kein doppelter Boden der Fiktion entwickeln wird. In der poststrukturalistischen Optik bedarf das Entstehen einer Tiefenkonstruktion eines Vorgehens, in dem „das Gleiten der Signifikanten (und damit die Bildung latenter Signifikate) nicht bewusst wird [...]“308 Jelineks Texte machen jedoch diese Signifikantenbewegung transparent, ,indem sie das konnotative Umfeld einholt und bestehende Metaphern [...] zerlegt. “" ${ }^{309}$ Der Leser scheint es somit mit einem Roman zu tun zu haben, in dem er nichts Geheimnisvolles oder Geheimbündlerisches findet. ${ }^{310}$ Der Text ist nur noch von der Oberflächenstruktur verbunden und die konsequente Verhinderung unbewusster Verknüpfungsmechanismen produziert einen statischen Text, einen Text ohne Spannung. ${ }^{311}$ Die Figuren in Lust haben auch keine Geschichte, die zeitstrukturierenden Momente einer Narration wie Erfahrung und Erinnerung sind hier nicht auffindbar, der Text ergeht sich in einer endlosen Synchronie, ${ }^{312}$ obwohl er eine linear verlaufende Handlung aufweist. Der Entzug der Tiefendimension mag den Leser nicht sofort beunruhigen, irritierend muss jedoch die Darstellungsweise des Erzählers wirken, dessen

\footnotetext{
${ }^{305}$ Gerhard Hoffman, Situationalismus als epistemologisches bzw. ethisches Grundmuster des zeitgenössischen amerikanischen Romans und die Umwandlung der erzählten Situation ins Fantastische, in: Gerhard Hoffmann (Hg.), Der zeitgenössische amerikanische Roman: Von der Moderne zur Postmoderne, Bd. 1 Elemente und Perspektiven, München 1988, S. 131 (diese Charakteristika formuliert Hoffmann in seiner Untersuchung amerikanischer Romane der Postmoderne, sie scheinen aber auch die Art der Gewaltinszenierung in Lust treffend zu beschreiben.) Klaudia Heidemann-Nebelin ist der Meinung, dass diese sehr arme Gestaltung der Figuren in Lust den Leser auf Distanz halte, indem er in keine psychologischen Konflikte der Figuren verwickelt werden kann. (Vgl. Klaudia Heidemann-Nebelin, Rotkäppchen erlegt den Wolf. Marieluise Fleißer, Christa Reinig und Elfriede Jelinek als satirische Schriftstellerinnen, Bonn 1994, S. 259.) Ob es so klar ist, darüber lässt sich streiten. Zweifelsohne ist aber solche Profilierung der Romancharaktere der erste Schritt in die Richtung der Störung und/oder Einschränkung der emotionalen Beteiligung des Textrezipienten während der Lektüre. Diese Störung und somit auch die Distanz zum Leiden der Protagonistin wird aber auch durch Fragmentierung der Erzählung aufrechterhalten.

${ }^{306}$ Günther A. Höfler, Vergrößerungsspiegel und Objektiv: Zur Fokussierung der Sexualität bei Elfriede Jelinek, in: Kurt Bartsch und Günther Höfler (Hg.), Elfriede Jelinek, Graz-Wien 1991, S. 155.

${ }^{307}$ Ebd., S. 155.

${ }^{308}$ Ebd., S. 159.

${ }^{309}$ Ebd.

${ }^{310}$ Vgl. Jutta Schlich, Phänomenologie der Wahrnehmung von Literatur. Am Beispiel von Elfriede Jelineks Lust (1989), Tübingen 1994, S. 278.

${ }^{311} \mathrm{Vgl}$. Günther A. Höfler, a. a. O., S. 159.

${ }^{312} \mathrm{Vgl}$. ebd.
} 
Bemühen um die erwähnte ,Transparenz der Signifikantenbewegung zunehmend verwirrende Züge anzuwenden sucht.

Die erzählerische Instanz in Lust bezeichnet Jutta Schlich als ein ,autonomes“, „,weil es je nach Gutdünken entweder imitativ oder intentional erzählen kann, wobei die intentionale Erzählhaltung in diesem Text eindeutig stärker ausgeprägt zu sein scheint.“313 Die schnell wechselnden Positionen des Erzählers gehören in meiner Überzeugung zu den meist irritierenden Momenten der Lektüre, in der der Leser vor allen Dingen zu bestimmen versucht, aus welcher Sicht das Erzählte vermittelt wird. Die folgenden Passagen zeigen dies sehr deutlich:

„Keine Hand holt diese von sich eingenommene und betrunkene Frau an ihren neuen Locken aus den Schneegruben heraus, die sie sich selbst gegraben hat. Gnädige Frau, wir trauern um unsre Freunde, die bereits nach Haus fahren mußten! Aber wir sind ja noch da, die Abonnements, mit denen wir über die Berge kommen wollen, hängen an unsrer warmen Brust. Wir wollen Sie nicht beleidigen, aber Ihre sichere Hütte haben Sie an unsicherstem Ort aufgestellt, das ist so, als hätten Sie überhaupt kein Heim. Von der Sonne werden diese jungen Leute beschissen, weil sie zu früh untergehen wird. Aber auch in der Dunkelheit werden sich sofort wieder Paare bilden.“ (L, 185)

„Die Jugend. So angehäuft ist sie in sich! Ich gehöre leider nicht mehr dazu. Und noch etwas: bei all ihren Geschäften lächeln sie, selbst im Schatten des Waldes, wo sie ihr Geschäft verrichten. [...] Sie lachen, das scheint ihnen oft das Beste zu sein, sorglos lenken sie die Töne aus ihren Walkmans in sich hinein, werden ganz unstet davon, weil sie der Musik, die in sie rinnt, nicht entkommen können. Von mir aus, wenn es ihnen nur gefällt! Und diese Frau muss sich ausgerechnet an ein Arschloch wie Michael hängen, der sich selbst, aber natürlich nicht seine Ziele längst aus den Augen verloren hat.“ (L, 191f)

Was bei der Betrachtung der beiden Passagen zunächst auffällt, ist die Vermischung von Fokalisierungen, aus denen die erzählte Welt dargestellt wird. Grundsätzlich herrscht in den beiden Passagen sowie in dem ganzen Roman die Nullfokalisierung, da die Erzähler

\footnotetext{
${ }^{313}$ Jutta Schlich, a. a. O., S. 66f. Der Terminus ,Erzählmedium‘ stammt von Wolfgang H. Schober und bezeichnet einen Erzähler, dessen „Wesen kaum fassbar [sei], wenn [er] auch manchen Charakterzug durch die Art seines Berichtes preisgibt. Der Autor verzichtet mit der Instanz des Erzählmediums auf die Beglaubigung des erzählten Inhalts: es wird fingiert, die Geschichte erzähle sich gleichsam selbst." Wolfgang H. Schober, Erzähltechniken in Romanen: Eine Untersuchung erzähltechnischer Probleme in zeitgenössischen Romanen (Diss.), Akad. Verl.-Ges. Athenaion, Wiesbaden 1975, S. 43, zit. nach Schlich, a.a.O., S. 66. Schlichs Buch Phänomenologie der Wahrnehmung von Literatur. Am Beispiel von Elfriede Jelineks Lust (1989) präsentiert als die einzige eine detaillierte Untersuchung der Narration in Lust.
} 
wesentlich mehr sagen und wissen als die Figuren. ${ }^{314}$ Als problematisch erweist sich aber das Bestimmen der Stellung des Erzählers zum Erzählten. Wir wissen zwar, dass der homodiegetische Erzähler keine der vier Figuren ist, er wird also als ein ,unbeteiligter Erzähler' und/oder ein ,unbeteiligter Beobachter' positioniert, wir können aber seine Stellung zum erzählten Geschehen nicht einsehen, da wir nach dem ersten obiger Lust-Passagen keine weiteren Informationen dazu erhalten, wer sich unter, wir ${ }^{6}$ versteckt und Gerti per Sie anspricht. Die zweite Passage beginnt in der Form der erlebten Rede. Der danach folgende Satz scheint die erzählende Instanz ein wenig zu enthüllen, indem sie uns verrät, dass sie nicht mehr jung sei. Die Stellung dieses Ichs zum Erzählten bleibt jedoch im Dunkeln.

Wie ich es an weiteren Textpassagen zu zeigen versuche, wird der Leser im Laufe der Lektüre seinen Kenntnisstand über den Erzähler, insbesondere über seine Weltanschauung und Einstellung zum Geschehen, mehrmals erneuern und modifizieren müssen. Zu Recht, wie es scheint, findet Schlich die Quelle des Desorientierungspotentials in Lust in der „außergewöhnlichen Dynamik der Erzählvorgänge.“315 Eine sehr starke Ausprägung des reflexiven Erzählvorgangs gegenüber dem faszinativen (imitativen) Erzählvorgang ist dafür verantwortlich, dass der Abstand zwischen den beiden derart vergrößert wird, dass „dem reflexiven Erzählvorgang sein Bezugspunkt - die Figuren auf der Handlungsebene abhanden kommt.، ${ }^{\text {316 }}$ Die teilweise Verwischung des faszinativen Erzählvorgangs führt nach Schlich zusätzlich zwangsläufig zu dem Eindruck, dass der Erzähler seine Rolle als Sinnkonstrukteur gar nicht erfülle. ${ }^{317}$

Diese originelle Dynamisierung der Narration in Lust, die den Roman zu einem komplex organisierten Werk entfaltet, macht eben seine, polyphon orchestrierte Rhetorik ${ }^{318}$ zur Herausforderung. Auf die nur scheinbar eindeutige - perzeptive, wie ich vermute Erzählperspektive im Roman weist auch Gertrud Koch hin, indem sie auf die Instabilität der Instanz des Ich-Erzählers aufmerksam macht. In der Lektüre von Lust wird nach Koch dem Leser schnell klar, dass „dieses >Ich< nicht Elfriede Jelinek, nicht die mahnende, ordnungsschafende und -spendende Autorin ist, sondern ein fragiles, literarisches Geschöpf, das die Fiktionen des Romans begleitet und mitunter akklamatorisch oder beratend und kommentierend dazwischenruft. ${ }^{(319}$ Die metanarrativen ${ }^{320}$ Kommentare des Erzählers machen

\footnotetext{
${ }^{314}$ Vgl. Matias Martinez, Michael Scheffel, Einführung in die Erzähltheorie, München 2005, S. 64.

315 Jutta Schlich, a. a. O., S. 162.

${ }^{316}$ Ebd.

${ }^{317} \mathrm{Vgl}$. ebd.

${ }^{318}$ Diese m. E. treffende Bezeichnung stammt von Gertrud Koch, Sittengemälde aus einem röm. kath. Land. Zum Roman Lust, in: Gegen den schönen Schein. Texte zu Elfriede Jelinek, Frankfurt (Main) 1990, S. 135.

${ }^{319}$ Ebd., S. $135 f$.
} 
den größten Teil des Romantextes aus. Somit sind das effektive Aufspüren der Funktionen, die die Erzählinstanzen erfüllen und das Bestimmen der Positionen, aus denen sie sprechen, von besonderer Bedeutung für die Konstitution des Sinns von Lust. Wie bereits angemerkt, wirkt der Erzähler nicht mahnend, wegweisend oder ordnungsschaffend. Es ist auch fraglich, ob er das Romangeschehen zu kontrollieren sucht. Durch ironische und spöttisch-verlachende Kommentare arbeitet er konsequent daran, die ,Lust am Text‘ zunichte zu machen. Dieses lässt sich ganz gut an dem ästhetischen Verfahren zeigen, in dem Jelinek mit dem Voyeur experimentiert: „Dadurch, daß Jelinek den ,Voyeur der Distanz“ zum Gelesenen ,beraubt“, konfrontiert sie ihn““321 „derart unmittelbar mit dem Gegenstand seiner Lust, daß sie ihm vergeht. “322 Diese Absicht formuliert Jelinek auch explizit in einem Interview:

„Ich habe $[\ldots]$ versucht, die Konsumierfreude an der ,Lust ${ }^{6}[\ldots]$ zu unterbinden durch ästhetische Fallen [...]. Die ,Lust‘ [...] soll [...] sozusagen dem Leser ins Gesicht zurückschlagen. Genauso wie im Hitchcock-Film ,das Fenster zum Hof'. Das ist ein gutes Beispiel. Es zeigt den Voyeur, aber gleichzeitig wird in diesem Voyeur der Voyeurismus der Zuschauer im Kino entlarvt. Das ist so ein ästhetischer Doppeltrick. “323

Schlich lokalisiert Stellen, die ,programmatisch für den ,Voyeurismus ' des Erzählers in Lust, der in wiederholten Apostrophierungen des Lesers diesen auf seinen eigenen ,Voyeurismus' zurückwirft“ ${ }^{324}$, sind. Im Anschluss an die Initiation eines Geschlechtsaktes zwischen Hermann und Gerti lesen wir: „Überall kann jeder hereinschauen und neidisch sein, wieviel Schönes von den Reichen verborgengehalten wird.“ (L, 18) Und später, nach der Feststellung, dass Gerti nur noch an Michael denkt, kommen auf den Leser-Voyeur folgende Worte zu: „Von ihrer Muschi führt nur noch ein schmales Wegerl weg, wo der Student mit all meinen Lesern steht und wartet, dass er, gebildet, mild in seiner Witterung, wieder herein darf.“ (L, 145) Schlich macht darauf aufmerksam, dass sich der Erzähler als Voyeur streng „vom schauenden Ich eines psychologisierenden Erzählers [unterscheidet], der das Dargestellte subjektiviert und so den unvermittelten Zugang zum Objekt der Darstellung verhindert. Ein solches Erzählich wird vielmehr durch die Zerstörung der Berichtform gänzlich annulliert.“325 Auf die Besonderheiten der Erzählvorgänge in ihrem Roman, macht selbst die Autorin aufmerksam:

\footnotetext{
${ }^{320}$ Vgl. Monika Fludernik, Einführung in die Erzähltheorie, Darmstadt 2006, S. 75.

321 Jutta Schlich, a. a. O., S. 63

322 Michael Scharang, Lebenselixier auf dem Misthaufen. Zu Elfriede Jelineks „Lust", in: Literatur Konkret H. 14, Hamburg 1989, S. 8.

${ }^{323}$ Birgit Lahann, Männer sehen in mir die große Domina, in: Stern 37 (1988), S. 78.

${ }^{324}$ Jutta Schlich, a. a. O., S. 63.

${ }^{325}$ Ebd., S.64.
} 
„Wenn ich über mich eine Doktorarbeit schriebe, würde ich wahrscheinlich die Bedeutung des Wir, des auktorialen Kommentars in der Erzählung, analysieren, der ja ständig seine Perspektive ändert. In späteren Sachen, z.B. in der Lust werden die Leute ja direkt angesprochen, oder ich spreche von mir in der Mehrzahl, es ändert sich also ständig, und man muss immer herausfinden, wer jetzt gerade spricht, welches Ich oder welches Ihr. Da verlasse ich die illusorische Ebene und gebe einen politischen Kommentar, der die Wahrheit hinter den Dingen kenntlich macht, aber man muss immer herausfinden, wer, welches Wer da spricht. “326

Ein aufmerksamer Leser muss sich daher ständig fragen, welche ,Wir ${ }^{6}$ oder ,Ihr ${ }^{6}$ werden gerade angesprochen und, ob er auch zu der gerade apostrophierten Gruppe von Lesern gehört? Der Erzähler spielt geschickt mit der Distanz zum Leser, indem es sich mit ihm zum Beispiel solidarisiert: „Wie Vieh hält man uns, und da machen wir uns noch Sorgen ums Fortkommen!“ $(\mathrm{L}, 13)$ „Ja, wir! Voller Qual werden wir sichtbar und wollen auch für andre hübsch sein, denn was haben wir nicht alles für unsre Kleidung ausgegeben, das uns jetzt fehlt, wenn wir uns vor unsrem Liebespartner ausziehen und verausgaben müssen.“(L, 209); an ihn ironisch appelliert: „Ich fordere Sie ernstlich auf: Luft und Lust für alle!“ (L, 105); sich bei ihm ironisch bedankt: „Vielen Dank, dass Sie meinen Beleidigungen zugehört haben“ (L, 144) oder sich von ihm mit einem gutmütigen Schlusswort verabschiedet ${ }^{327}$ : „Aber nun rastet eine Weile!“ (L, 255) Eine zusätzliche Irritation kommt hinzu, wenn sich das Geschlecht des Erzähl-Ichs nicht eindeutig feststellen lässt. Oft sieht sich der Leser in der Annahme bestätigt, der Erzähler sei weiblich: „[...] wie wir Frauen es gern und ergebnislos versuchen [...]“ (L, 68), „Wir Damen müssen uns mit harter Hand auf die Weide säen, [...]“ (L, 184) Irgendwann liest man aber erstaunt Sätze: „Von der Hüfte abwärts gehören wir Männer eben zusammen. Das heißt, wir gehören unsren Frauen und lassen uns auf der Straße, ohne uns zu wehren, Schicksalslose in die Hand drücken.“ (L, 244) Nicht umsonst, wie es scheint, brüskiert dieser Perspektivenwechsel die Leser, die dem Roman die weibliche Erzählperspektive zugeschrieben haben. ${ }^{328}$ Zweifellos erzeugt der Text im Spiel mit den geschlechtsspezifischen Momenten eine Spannung, die konsequent zunimmt und den Leser im Prozess der Sinnbildung an eine komplexere tiefere Motivation denken lässt. Susanne Baackmann situiert die Quelle dieser Spannung im Spiel

\footnotetext{
${ }^{326}$ Elfriede Jelinek Jutta Heinrich Adolf-Ernst Meyer, Sturm und Zwang. Schreiben als Geschlechterkampf, Hamburg 1995, S. 28.

${ }^{327}$ Vgl. Susanne Baackmann, Erklär mir Liebe. Weibliche Schreibweisen von Liebe in der Gegenwartsliteratur, Hamburg 1995, S. 182.

${ }^{328}$ Vgl. ebd. Baackman spricht hier zwar vom Perspektivenwechsel, genauer gesagt handelt es sich hier aber um die Änderung der Identitätsmerkmale der Erzählinstanz (diese treffende Bemerkung verdanke ich meiner Doktormutter, Frau Prof. Simone Winko.) Solche Überraschungen verwirren den Leser weit stärker als bloße Wechsel der (perzeptiven) Perspektive.
} 
„Zwischen dem ,männlichen“ Blick auf das weibliche Körperobjekt und der ,weiblichen“ Erzählkommentierung dieses Blicks. Diese Spannung zwischen Erzählgegenstand, perspektive und ErzählerInnenkommentar macht auf allgemein verbreitete Voreingenommenheiten und stilschweigende Annahmen aufmerksam, mithin auf den Prozess der textuellen und rezeptiven Konstruktion von Geschlechtlichkeit und die Implikationen dieses Prozesses.“329

Baackmann bemerkt, dass die fluktuierende Perspektive, die scheinbar auktoriale Neutralität des Erzählers fragwürdig macht, die Frage - Wer urteilt hier über ,die Frau' und ,den Mann` - bleibt somit offen. ${ }^{330}$ Die Fragen nach dem Bild von Sexualität, Gesellschaft, Frauen- und Männerkörper, die Jelineks Lust evoziert, stellen sich die meisten Interpreten dieses Romans. Das Spiel mit Perspektiven, diese ,vielfältige Orchestrierung des ,Ich“ und des ,Wir“‘331 führt jedoch nicht, wie es Gertrud Koch betont, zu einem Relativismus. Sie weist auf die subkutane Struktur hin, ,die auch den Diskurs über die Sexualität in diesem Buch festschreibt: Die der Macht- und Besitzverhältnisse. “332

Wegen fehlender Kongruenz zwischen dem Romantext Lust und den in ihm dargestellten Phänomenen muss der Leser, der den Roman auf der reinen Abbildebene zu lesen versucht, zwangsläufig scheitern. ${ }^{333}$ Die Frage nach der Realitätsabbildung in Lust scheint nach Heidemann am Text vorbeizugehen:

„Statt einer Geschichte, einer Handlung im traditionellen Sinn, haben die Leser ein höchst artifizielles Text-Konstrukt vor sich, das eine sehr eigenwillige Dynamik entwickelt: Die Durchquerung der verschiedenen kulturellen Diskurse lässt weder eine Identifikation mit den Figuren noch den einfachen Konsum des Textes zu. ${ }^{\text {(334 }}$

Was stört aber so besonders den einfachen Konsum des Romans Lust? Die Antwort ist vor allem in der Analyse der Sprache zu suchen. Die Lektüre hinterlässt zuerst den Eindruck, ,als habe sich nichts anderes als Sprache ereignet $[\ldots]^{6335}$ Die auf einer Sehweise basierenden scharfen Beschreibungen ${ }^{336}$ ähneln in der Form dem Blick „eines Naturforschers, der aus großer Entfernung auf gesellschaftliche Prozesse schaut, um sie präzise beschreiben zu

\footnotetext{
${ }^{329}$ Ebd., S. 182. Dem Problem der Konstruktion von Geschlechtlichkeit in Lust widme ich das dritte Kapitel.

${ }^{330}$ Vgl. ebd., S. 182.

${ }^{331}$ Gertrud Koch, a. a. O., S. 136.

${ }^{332}$ Ebd., S. 136.

${ }^{333}$ Vgl. Heidemann, a. a. O., S. $253 \mathrm{ff}$.

${ }^{334}$ Ebd.

${ }^{335}$ Jutta Schlich, a. a. O., S. 194. „Gerade in Lust kommt Jelineks Technik zum Vorschein, einen Text von der Sprache her aufzubauen - ein Charakteristikum, das man immer wieder den Volksstücken und Prosawerken ihres Landsmanns Ödön von Horváth nachsagte."

${ }^{336}$ Vgl. Günther A. Höfler, a. a. O., S. 155.
} 
können.“ 337 Jelinek scheint tatsächlich die für die Naturwissenschaften typischen ,Protokollsätze‘ für die Literatur entdeckt und übernommen zu haben: ${ }^{338}$

„Angewandt auf die soziale Realität und zugespitzt bis zur pointilistischen Auflösung der Situationen und der Handlungsdetails in ihre spektralen Elemente schlägt die Darstellung des Realen um in dessen Verurteilung.“339

Die Lust-Autorin schreibt aber auch in einer Sprache, die von einem Assoziationswahnsinn erzeugt wird, ,verballhornte Bibel- und Hölderlinzitate prallen auf albernste Kalauer; Werbesprüche, Aphorismen und Stammtischprahlereien werden zu vorsätzlich, schiefen Bildern gebogen, und alles regiert die Geschmacklosigkeit brutaler Obszönitäten. “ ${ }^{340}$ Der Text wirkt dadurch befremdend, schreckt ab, die Worte multiplizieren sich nach einem unbekannten Muster, indem in den einzelnen Passagen keine plausiblen thematischen Verknüpfungen zu finden sind. Eine zügige Lektüre stören erheblich die Unterbrechungen des Berichts, an dessen Stelle Jelinek das Montageverfahren konstruiert. Durch die Montageeinlagen ,werden die Motive, die Bilder der Gleichnisebenen von der Vorherrschaft durch Figur, Handlung und Erzähler erst wirklich befreit. “341 Darüber hinaus unterbricht und facettiert das Montageverfahren „den normalen Zeitverlauf, stell[ $\mathrm{t}]$ ein Retardierungsmoment dar, das die Zeit des Geschehens zum Stillstand zu bringen scheint.“342

Sollte Jelinek die Textwirklichkeit in Lust durch die Sprachrealität konstruieren, so wäre der Roman einem Signifikantenspiel ${ }^{343}$ gleich, in dem die Wortketten auf nichts verweisen, indem sie keine Sinnhaftigkeit für das Verständnis des Romans als Ganzes stiften und nur noch ,aus flottierenden Signifikantenketten in Abwesenheit eines Signifikats““344 bestehen. Die einzige Aufgabe der Sprache in Lust wäre dann, nur da zu sein, „der literarische Ertrag

\footnotetext{
${ }^{337}$ Elfriede Jelinek, zit. nach Günther A. Höfler, a. a. O., S. 155.

${ }^{338}$ Vgl. Rudolf Burger, a. a. O., S. $21 \mathrm{f}$.

${ }^{339}$ Ebd.

${ }^{340}$ Andreas Isenschmid, a. a. O., S. 240.

${ }^{341}$ Otto Keller, Döblins Montageroman, zit. nach Jutta Schlich, a. a. O., S.64. „Beispielsweise erfüllen die einzelnen Absätze in einem Kapitel keine Ordnungsfunktion, ja selbst die Gliederungsabsicht, wie sie in der Kapiteleinteilung zum Ausdruck kommen soll, ist nicht auf Anhieb rekonstruierbar, da die Assoziationslust des Erzählers vorwiegend den im ersten Satz eines Absatzes oder auch Kapitels angeklungenen thematischen Schwerpunkt wieder aufgibt." (ebd., S. 64f.)

342 Jutta Schlich, a. a. O., S. 79.

${ }^{343} \mathrm{VgI}$. Anja Meyer, Elfriede Jelinek in der Geschlechterpresse. Die Klavierspielerin und Lust im printmedialen Diskurs, Hildesheim, Zürich, New York 1994, S. 47f. Die Frage, ob Jelineks Texte realistisch sind, verbindet Meyer mit dem Begriff des Überrealismus, den sie aus der Freudschen Psychoanalyse leiht. „Ein ausgeprägt strafendes Über-Ich scheint Jelineks destruktives Schreibverfahren zu prägen - ein Mechanismus, der - nach Freud - zu kulturellen Leistungen befähigt, den dieser den meisten Frauen seiner Zeit aber nicht zugestand. Sie könne nicht anders schreiben als in einer Ästhetik der Wut, umreißt Jelinek ihren Schreibort."

${ }^{344}$ Tom Mustroph, Lektüren. Von der Autorintention hin zur freien Semiose. Schleiermacher-Gadamer-IserDerrida. Pynchon-Kundera-Jelinek, Marburg 2000, S. $108 \mathrm{f}$.
} 
von Lust [wäre - K.S.] im Sprachexperiment zu suchen. “345 Die sprachliche Gestaltung des Romans könnte jedoch das gut camouflierte Ziel haben, die in die Sprache eingeschriebenen latenten Denkkategorien offenzulegen:

„Im Versuch, durch grelle sprachliche Beleuchtung, die im übersteigerten Klischee versteckte Wahrheit anzuleuchten. Im Versuch, durch obszönes Überschreiten der sprachlichen Schmerzgrenzen den fühllosen Schmerz fühlbar zu machen, den Frauen erfahren, wenn ihre Körper nicht mehr Subjekte eigener Lust, sondern nur mehr Objekte rücksichtsloser Männerlust sind. Im Versuch durch Erfindung einer neuen Sprache das Bekannte des Klischees in ein erkanntes und neu Erfühltes zu verwandeln.“ 346

Der (pseudo)pornografische, direkte, metaphernfreie Roman Lust liefert jedoch mehr als einen sprachlich verwirrenden politischen Text, der die antipatriarchalen Momente hervorbringt und „das Verhältnis der Geschlechter nach dem Muster Aggressor-Opfer, Machthaber-Machtobjekt “347 abzubilden sucht. Die aufmerksame Lektüre lässt die Wirkung einer Subversion sondieren, deren Aufspüren, wie ich meine, nicht nur eine neue, zum Teil zerstörte, ,Lust am Text' erweckt, sondern vor allem aus dem Roman Lust tiefgreifende Implikationen herauskristallisieren lässt. Dieses subversive Moment möchte ich im letzten Teil dieses Kapitels thematisieren.

Rudolf Burger weist darauf hin, dass wegen der fehlenden Souveränität des Subjekts Jelineks Romane nicht als ,existenzialistisch` gelten können und führt präzise ein neuartiges Charakteristikum ihrer Prosawerke aus: „Bildete das Individuum das fiktive Atom der liberalen bürgerlichen Gesellschaft und ihrer Literatur, so wären die Elementargrößen der Handlung bei Jelinek als gleichzeitig molekular und subatomar zu bezeichnen." ${ }^{348}$ Das Molekulare sieht Burger in der Einzwängung des gesamten Handlungsablaufs in Machtverhältnisse, die als unüberschreitbar konzipiert sind. Die Figuren „sind paarweise zu Herr/Knecht-Dipolen zusammengekettet, um gegeneinander ihre Strategien und Taktiken der Beherrschung zu entwickeln, die ihre Existenz ausmacht; als einzelne gibt es sie nicht, sie

\footnotetext{
${ }^{345}$ Andreas Isenschmid, a. a. O., S. 242f. Isenschmid schlussfolgert, Lust sei im Endeffekt ein ,Trivialroman in experimenteller Tarnung'. Er wirft Jelinek Missbrauch eines Themas vor, „das Aufmerksam verdiente für stilistische Fingerübungen." Diese Meinung werde ich nicht teilen.

${ }^{346}$ Ebd.

${ }^{347}$ Tom Mustroph, a. a. O., S. 108f. „Jelinek öffnet nicht einen erweiterten Raum von Bedeutungen. Ihr Verfahren ist keines der Abbildung, auch keines von Parodie und Travestie. Jedenfalls wäre es zu kurz gefasst, wollte man Jelineks Prosa lediglich als - intendierte - Subversion und Zertrümmerung von Trivialmythen und sozialer Realität beschreiben."

${ }^{348}$ Rudolf Burger, a. a. O., S. $21 \mathrm{f}$.
} 
existieren nur als Clustern. “349 Als subatomar bezeichnet Burger dagegen die Triebkräfte des Geschehens, die hier nur noch als ,versprengte, unverbundene, von ihren Trägern losgelöste und auseinanderfallende, durch keine mit sich selbst identische Subjektivität vereinigte und irgendwie harmonisierte Partialbegierden, nicht synthetisierte Komponenten dessen, was euphemistisch einmal ,Persönlichkeit ${ }^{\star}$ hieß“ ${ }^{350}$, funktionieren. Diese konsequent durchgeführte Vertreibung des Psychologischen aus ihren früheren Romanen spitzt Jelinek in Lust noch mit einem Novum zu. Indem sie ihre Protagonisten ohne Vorgeschichte ins Romangeschehen wirft, sind sie hier ,in keiner Weise mehr ,motiviert', auch nicht im negativen Sinne, sondern reduziert auf Gewalt generierende Sprachwirkungen.“ ${ }^{351} \mathrm{Ob}$ die Eliminierung der Souveränität der Figuren und ihrer Vorgeschichten in Lust während der Lektüre als misslungen oder langweilig empfunden wird, ist schon Geschmacksache. Dieser Eingriff hat jedoch, wie es Ina Hartwig schlussfolgert, eine schwerwiegende Implikation, nämlich das Fehlen des Motivs des Kindsmords am Ende des Romans:

„Denn es ist nicht klar, als Repräsentant welcher Geschichte - welcher Not oder welcher Gewalt - der Sohn überhaupt begriffen werden soll. Deutlich ist allein, dass dem Motiv des Kindsmords die auch in der Literatur tradierte Suggestion anhaftet, Konsequenz zu sein. Es fragt sich allerdings, Konsequenz wovon: von Aggression, von ökonomischen Verhältnissen, Konsequenz der Ehe, der Sprache, der Pornographie?‘352

Somit wäre auch Kurt Bartsch“ Behauptung, ,in Jelineks Texte führt kein hermeneutischer Weg, den der Leser in traditionellem Verstehen verbreitern könnte“6353, durchaus berechtigt.

„Die Sprache selbst will jetzt sprechen gehen,“ (L, 28) aber „Worte reichen dafür nicht aus.“ (L, 50) 255 Seiten, mit drängenden und sich drängelnden Worten gefüllt, die dann doch nicht ausreichend, nicht treffend genug sind, um eine (durch den Erzähler) imaginierte, unklare Absicht auszudrücken? Die strategische Entscheidung, die der Leser angesichts der obigen Verweise treffen muss, wird die Art und Weise seiner weiteren Lektüre in ihrer Zielsetzung determinieren: Entweder ignoriert er den Hinweis, nimmt ihn nicht ernst und setzt seine mühevolle Arbeit des Bedeutungsfixierens fort oder widmet er seine Aufmerksamkeit

\footnotetext{
${ }^{349}$ Ebd.

${ }^{350}$ Ebd., S. 22. Burger weist somit auf die Dehumanisierung Jelinekschen Figuren hin, „zur unvermittelten Einheit von biologischer Bedürftigkeit und sozialer Determination."

${ }^{351}$ Ina Hartwig, Sexuelle Poetik. Proust Musil Genet Jelinek, Frankfurt am Main 1998, S. $235 f$.

${ }^{352}$ Ebd.

${ }^{353}$ Günther A. Höfler, a. a. O., S. 155. „Die Schreibweise dieser Autorin ist unepisch, also nicht auf symbolische Größen wie Schicksal, Glück oder verborgene seelische Dimensionen bezogen. Das Material ist vielmehr collagenhaft flächig angeordnet. Dadurch wird kein Sinn in der für die Hermeneutik relevanten Bedeutung erzeugt."
} 
nur noch dem Sprachlichen, den gescheiterten Worten, den Resten einer misslungenen Transformation des Imaginären ins Symbolische. Der Text Lust wird konsequent eine Störung entfalten, die dem Rezipienten den Wandel der natürlichen Leseeinstellung erzwingt, indem seine Erwartung auf das Bestehen einer Tiefendimension, d.h. einer sinnhaftigkeitskonstituierenden Schicht, wiederholt unterlaufen wird. Die chaotische Verschachtelung von Informationen und Kommentaren aus unterschiedlichen thematischen Bereichen, ohne erkennbare Muster aneinander gereiht, werden wahrscheinlich den Leser das Gelesene nicht vernünftig hierarchisieren und ordnen lassen. Nach dem Motto: Was passt, wird unpassend gemacht, stellt die Lust-Autorin Textpassagen zusammen, die nicht miteinander koexistieren wollen und sich spürbar abstoßen, als äußerst inkompatibel wirkend. Die erste Verwirrung würde dann aus der Tatsache resultieren, dass die textstrategische Konzipierung des Romans „,in ihren zahlreichen intra- und intertextuellen Verweisen [...] eine unrealistisch hohe Präsenz

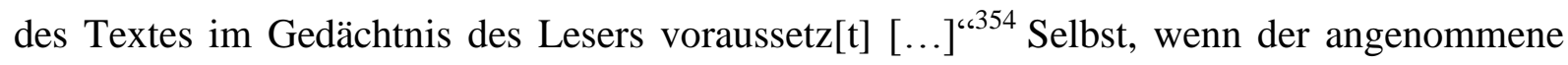
Modell-Leser ,über ein bestimmtes kulturelles Wissen verfüg[t], um Voraussetzungen zu ergänzen und Anspielungen verstehen zu können““355, bleibt er wahrscheinlich noch weit davon entfernt, mehrere Lust-Passagen als miteinander sinnhaft verbundene Teile deuten zu können. Ein gutes Beispiel solcher Textstrategie liefert die folgende Passage:

„In den Hitlerzimmern der Tankstellen schlagen sie jetzt wieder aufeinander ein, diese kleinen Geschlechter an ihren Gängelbändern, die sich unter ihren bunten Schirmchen verschwenden wie ihre halben Portionen Eis. So schnell ist es immer vorbei, und so lang dauert die Arbeit und stehen die Felsen. Diese Leute können sich durch endlose Wiederholungen doch nur einfach vervielfältigen. Diese hungrige Meute, die zieht ihr Geschlecht aus den Türln, die sie praktisch an sich angebracht hat. Fenster haben diese Leute nicht, damit sie ihre Partner dabei nicht auch noch anschauen müssen. Wie Vieh hält man uns, und da machen wir uns noch Sorgen ums Fortkommen!“‘ (L, 13)

Die zitierte Passage steht in keinem thematischen Zusammenhang mit dem davor und dem danach Präsentierten, sie steht also nur für sich da, als ein spontan (hinein)assoziierte Gedanke. Was in diesem Textausschnitt als Erstes die Aufmerksamkeit fokussiert, sind die ,Hitlerzimmer der Tankstellen`. Mit ,Hitler' wird ein Bereich des geschichtlichen Wissens aktiviert, das in den danach folgenden Sätzen nach thematisch-kompatibler Fortsetzung sucht. Dieser scheint jedoch eindeutig zu fehlen und die wiederholte Lektüre der Passage wird zu einem Versteckspiel im Sinne ,pin the signifier to the signifiant', wobei das Letzte, d.h. die

\footnotetext{
${ }^{354}$ Fotis Jannidis, Figur und Person. Beitrag zu einer historischen Narratologie, Berlin, New York 2004, S. 136.

${ }^{355}$ Ebd., S. 137.
} 
Bedeutung der Textstelle (mit der Evozierung Hitlers), nicht zu finden ist. Unklar sind auch weitere Momente in dieser Passage; wir wissen nicht, welche Leute mit ,diese Leute‘ gemeint seien, was unter ,Gängelbänder' zu verstehen sei, was es zu bedeuten habe, dass man ,uns wie Vieh hält'.

Das Subversive, das einst zwischen den Worten lauerte, sich hinter den Worten zu verstecken suchte, hat hier dem Versteckspiel ein Ende gesetzt und sich bequem an der Textoberfläche breit gemacht. Diese ausgeklügelte Hyper-Subversion wird zwar im Rezeptionsakt aktiviert und allmählich als etwas kaum Konzeptualisierbares wahrgenommen, ihr erfolgreiches Aufspüren kann jedoch, wie ich meine, nicht erschöpfend vollzogen werden. Die primäre Lektüre von Lust birgt in sich das Potenzial einer Qual. Die oft obsessive Suche nach Bedeutung des fragmentierten Textes, nach Einheit und Kohärenz, der fast jedes Wort und fast jeder Satz wegweisend und/oder suspekt erscheint, kann dabei diese Qual noch potenzieren. Das Unbehagen, die Enttäuschung und die potenzielle Desorientierung sähe ich hier als vorprogrammiert. Es wird nicht leicht, sich an die Sprachmanier in Lust zu gewöhnen, zu intensiv, zu negativ, zu irrsinnig scheint m.E. Jelineks Assoziationsdrang zu wirken. Die Interpretationsmechanismen können während der Lektüre den Abwehrmechanismen weichen: Man kann versuchen, sich nicht provozieren zu lassen, man möchte vielleicht dem allgegenwärtigen Pessimismus standhalten, man hofft, all die geschilderten Obszönitäten schnell aus dem Gedächtnis loswerden zu können. Konsequent entfaltet der Lust-Text das Potenzial der Maximierung der Verwirrtheit des Lesers. Die Subversion an der Oberfläche scheint dabei die erste Irritationsquelle zu markieren. Gleich danach kommt das Dilemma der scheinbar pornografischen Inhalte im Roman. Am intensivsten entfaltet aber Lust seine subversive Wirkung - so nochmals meine Hauptthese - durch das Hinterlassen der Spuren und Reste eines gescheiterten Projektes der Autorin - einen anti-pornografischen Roman zu schreiben und dem Obszönen eine weibliche Perspektive zu verleihen. ${ }^{356}$

Der Weg zur Anti-Pornografie scheint über das Pornografische zu führen. Die Frage, die sich dabei aufwirft, ist, ob (und wie weit) sich Pornografie oder generell das Obszöne subvertieren lässt. Sollte die Frage bejaht werden, so müsste man wiederum danach fragen, ob die Subversion des Pornografischen eine neue (ästhetische) Qualität hervorbringt, die sich abgeschieden von dem Obszönen untersuchen lässt. Erst die Beantwortung dieser Fragen ermöglicht uns die Annäherung an den Grund des Misslingens des Jelinekschen Projekts, hilft diesen präzis zu thematisieren und hilft mögliche Erklärungen zu formulieren.

\footnotetext{
${ }^{356}$ Vgl. Zit. 373 und die dazu gehörende Erläuterung in der Fußnote auf S. 104.
} 


\subsection{Lust als ein (anti)pornografischer Roman}

„In dem Moment, in dem ich etwas Positives beschreibe,
werde ich literarisch uninteressant und flach.“
E. Jelinek

Pornografieverdächtig sind grob genommen drei Momente im Roman Lust und erst durch eine präzise Belichtung jedes von ihnen könnte man zu schlussfolgern versuchen, ob Lust sich als ein pornografischer Roman klassifizieren lässt. Erstens ist selbst der Titel durch seine Doppeldeutigkeit seltsam anrüchig, zweitens mag auch der thematische Kern von Lust vergewaltigungsähnliche Sexszenen, fast gleich in ihren Verläufen - einen Pornoverdacht wecken und drittens ist die Sprache, die die Autorin zur Darstellung dieser Szenen benutzt, mehr als obszön.

Das Wort ,Lust“ benennt im Deutschen zwei Zustände: „Vorlust im Sinne der Sexualspannung und Befriedigungslust.“ ${ }^{357}$ Diese Doppeldeutigkeit weiß Jelinek geschickt und provokatorisch in ihrem Roman zu integrieren, indem „sie der Befriedigungslust - eines bestimmten Lesertyps - eine grobe Abfuhr erteilt.“" ${ }^{358}$ Mit dieser Behauptung scheint Ina Hartwig den Hinweis zu geben, Lust sei nicht rein/einfach pornografisch. Fast pathetisch klingt ihre Zusammenfassung, was der Roman in puncto Sexus liefern solle:

„Lust ist schwere literarische Arbeit am Monument des Sexus: Ein Gefecht des Sexes gegen den Sex, eine Implosion der sprachlichen Verfasstheit von Geschlechtlichkeit. Eine Ridikülisierung der Pornographie mit ihren eigenen Mitteln. Ein Krieg der Genitalien als Groteske. Die Auflösung der Kopulation in der Abstraktion. Die theoretische Übersättigung und damit, letztlich die Zerstörung des Sexus.، ${ }^{\text {‘39 }}$

Ob Lust alle die oben genannten Momente hervorbringt und entfaltet, bleibt jedoch umstritten; eine konkretere Frage wäre dagegen, inwieweit die von Hartwig behauptete „Ridikülisierung der Pornografie mit ihren eigenen Mitteln“ ${ }^{360}$ den pornografischen Gehalt eines Textes modifiziert bzw. seine Wirkung verändert. Zuerst muss aber untersucht werden, was in der Darstellung der Sexualakte in Lust als eindeutig pornographisch einzustufen sei. Folgende

\footnotetext{
${ }^{357}$ Ina Hartwig, Schwere Arbeit am Monument des Sexus. Über Elfriede Jelineks Lust, in: Heinz Ludwig Arnold (Hg.), Elfriede Jelinek, München 2007, S. 80. „Jelineks Distinktion der Lüste will hier nur - aber das ist gerade viel - ein artistisches Signifikantenspiel sein: Es gibt kein Signifikat der Lust.“, S. 248.

${ }^{358}$ Ebd., S. 80.

${ }^{359}$ Ebd. S. 81

360 Ebd.
} 
Textausschnitte zeigen deutlich, auf welche Art und Weise die Sexualhandlungen verbalisiert werden:

„Schnell ist der Schwanz des Mannes in dieser freundlichen Umgebung aufgewachsen. Die Frau muss husten, während ihr die Flanken geweitet werden. Der Büchsenöffner wird aus der grauenhaften Flanellhose gezogen, und eine milchige Flüssigkeit erscheint, nachdem der Mann etwa eine Weile, die ein Fettfleck braucht, eingewirkt hat und liebend sich in einer stacheligen Haarwolke ertönen hat lassen. Viel zu früh tritt das Glied aus seinem Fach ans Licht hinaus. Die Frau, der ihr Arsch, diese schattige Straße, aufs äußerte aufgespreizt worden ist, muss hinter dem Mann zurückstehen bleiben. Er reißt ihr Steuer herum und zwingt sie, ihn anzuschauen. Er kehrt sich wütend ihre Vorderfront $\mathrm{zu}$, zwingt sie, seinen verhallenden Pimmel anzufassen, der schon wieder zu zucken beginnt, will er doch wohnen in dir, du liebe Zeit, und in Ihnen, Sie liebende Nacht! Er drückt der Frau das Haar in seinen Erguß, in den Rest davon, den ihre einfältigen Augen erblicken sollen. Schwer denken sie nach, die Helden, wenn ihre Arbeit getan ist. Die Frau wird mit Sperma eingeschmiert.“ $(L, 39)^{361}$

„Der Student presst die Frau an sich. Das Zischen, das aus seinem Ventil dringt, kann er selbst mit einem kleinen Griff an seinen Kochtopf, der übervoll ist, beheben. Er möchte noch nicht abspritzen, er möchte aber auch nicht umsonst drauf gewartet haben. Er zwickt mit geschickten Händen die Frau in den unschicklichsten Teil ihres weich in seiner gepolsterten Kiste sitzenden Fleisches, damit sie die Beine noch weiter spreizen muss. Er wühlt in ihrem schlummrigen Geschlecht, dreht es zu einer Tüte zusammen und lässt es jäh wieder zurückschnalzen. Sollte er sich nicht entschuldigen, dass er sie schlechter behandelt als seine Tonmöbel? Klatschend schlägt er ihr auf den Hintern, um sie gleich darauf wieder auf den Rücken zu wälzen. Gewiss wird er nachher gut schlafen können, nicht anders als die Wesen, die ehrlich gearbeitet, miteinander gekost und einiges gekostet haben.“ ( L, 113)

Die zitierten Stellen, eine Schilderung der Vergewaltigung Gertis durch ihren Mann sowie der Seitensprung Gertis mit dem Studenten Michael machen den Eindruck eines pornografischen Inhalts. Ihre Strukturierung, der Gebrauch des eigentümlichen Vokabulars und das Einflechten von Kommentaren bzw. Anreden scheinen jedoch den rein pornografischen Effekt zu unterlaufen. Was aber in der Lektüre der unzähligen Sexszenen im Roman vor allem auffällt, ist die Tatsache, dass,

„wenn in ,Lust" von Sex die Rede ist, ist immer auch von etwas anderem die Rede. Nur das Problem ist, dass eben auch dann von Sex die Rede ist, wenn von etwas anderem die Rede ist

${ }^{361}$ Ich zitiere lediglich die letzten Momente der Sexszenen, die durch zahlreiche Kommentare und Apostrophierungen unterbrochen, sich auf mehrere Seiten erstrecken. 
[...] In alle Sprachen, deren sich Jelinek bedient, wird eine sexuelle Dimension eingeschleust; Sprachen des Haushalts, des Fernsehens, des Hobbys, des Sports [... $]^{6362}$

Die Wahl der Bezeichnungen, mit denen das Genital des Mannes benannt wird, evoziert meistens Assoziationen mit dem Maschinellen, Mechanischen und Automatischen ${ }^{363}$ (wie bei ,elektrischer Leitung', ,spuckendem Spender‘, ,Büchsenöffner', ,Kolben` oder ,Rohr` der Fall ist). Die Geschlechtsorgane der Protagonistin werden dagegen vor allem durch Gegenstände repräsentiert, die die Eigenschaft einer Öffnung besitzen wie ,Sparbüchse‘, ,Klomuschel', ,Öse‘, ,Kofferraum“ oder ,Hintertüren“. ${ }^{364}$ Durch das Vermengen des (zwanghaft) sexualisierten Vokabulars mit Begriffen, die dem sexuellen Kontext entstammen, wird, wie es scheint, der pornografische Effekt deutlich verzehrt.

Das Ziel eines pornografischen Romans lässt sich jedenfalls relativ klar bestimmen: „Er will bei seinem Leser die sexuelle Begierde wecken, ihn in eine Zustand der Spannung und des Mangels versetzen, aus dem er sich durch ein außerliterarisches Mittel befreien muss. “365 Der pornografische Text muss daher strategisch und präzise konzipiert werden, denn ,jedes von diesem ,pornographischen Effekt" ablenkende Moment des pornographischen Textes tritt im pornographischen Diskurs als ,Störfaktor“ auf.“ ${ }^{366}$ Das wichtigste Element dieser Erzählstrategie sei die aus der strukturellen Monotonie resultierende Eindimensionalität, charakteristisch durch ihre „Struktur der reinen Addition, 'parataktisch“ organisierter Handlungssegmente (Episoden, Sexualakte). “367 Jens von Fintel macht darauf aufmerksam, dass Jelinek die spezifisch pornografische Monotonie in Lust noch steigere, indem sie die ,inszenatorische Variation der Sexualhandlungen' minimalisiere. Dieser Eingriff hat nach von Fintel eine anti-pornografische Wirkung, da hier nicht mehr, wie in einem pornografischen Text ständig neue Arrangements in den Sexszenen der Monotonie entgegenwirken, sondern die Monotonie selbst hervorgehoben wird. ${ }^{368}$ Dieses Argument scheint mir jedoch nicht ganz überzeugend zu sein. Der gesteigerten Monotonie schreibt von Fintel eine Wirkung zu, die sie meines Erachtens nicht erfüllt. Die Hervorhebung der

\footnotetext{
362 Ina Hartwig, Sexuelle Poetik. Proust Musil Genet Jelinek, Frankfurt am Main 1998, S. 259f. Zu Recht bemerkt Hartwig, dass diese Textstrategie in einen sprachlichen Pansexualismus münde und dass dadurch "die Grenze zum Absurden, zum Kalauer, zur Groteske erreicht“ werde. (Ebd., S. 260.) Hartwig macht auch darauf aufmerksam, dass der Penis „mehr Denominationen erfährt als das weibliche Genital“ Ebd., S. 261.

${ }^{363} \mathrm{Vgl}$. Mustroph, a.a.O., S. 109.

${ }^{364} \mathrm{Vgl}$. ebd.

365 Jens von Fintel, Zur Dekonstruktion des pornographischen Diskurses. Elfriede Jelineks Lust, www.vonfintel.de/texte/geisteswissenschaft/jelinek.htm (Stand: 13. Sep. 2013)

${ }^{366}$ Ebd. Von Fintel spricht in diesem Sinne von restriktiver erzählstrategischer Ökonomie.

${ }^{367} \mathrm{Ebd}$.

${ }^{368} \mathrm{Vgl}$. ebd.
} 
Eintönigkeit des Sexuellen, so, wie sie in Lust zum Ausdruck kommt, mag den Leser zwar langweilen, sie destruiert jedoch keineswegs ihren pornografischen Effekt. Die Minimalisierung der ,inszenatorischen Variation der Sexualhandlungen', wie es von Fintel nennt, mag zwar den Eindruck erwecken, es wird hier mehrmals (fast) die gleiche Szene abgespielt, bei deren nachfolgenden Darstellungen sich lediglich das gebrauchte Vokabular ändert. Selbst dadurch wird jedoch meines Erachtens das pornografische Moment nicht aufgelöst, obwohl die gesteigerte Eintönigkeit des Umgangs Hermanns mit Gerti, den pornografischen Diskurs stark subvertiert und diesen bis zum Absurden verzerren mag.

Wie es sich zeigt, versuchen einige Interpreten im Roman Lust Momente zu finden, die das Werk als nicht-pornografisch klassifizieren lassen. Ina Hartwig lokalisiert zuerst im Text Stellen, die sich eindeutig an pornografischen Sujets orientieren: „männliche Dauerpotenz, Geschichtslosigkeit und folglich, Austauschbarkeit der Protagonisten. “369 Sie weist auf das in Lust herrschende Tempus - das Präsens und den Erzählmodus - den Indikativ hin, die auch für die Darstellung pornografischer Szenen spezifisch seien. ${ }^{370}$ Hartwig weigert sich jedoch, Jelineks sexuelle Poetik ${ }^{371}$ als eindeutig pornografisch einzustufen, weil „sie eines der entscheidenden pornographischen Sujets nicht übernimmt: nämlich die Lust der Frau.“372 Die Sprache des Sexes, die Jelinek gebraucht, bezeichnet Hartwig als falsch und widerwärtig, trotzdem soll die Lust-Autorin mit dieser Sprache triumphieren, obwohl ausschließlich negativ. ${ }^{373}$ Worauf aber dieser negative Triumph beruhen sollte, ist nicht klar, zumal Jelinek in dem Versuch, dem Obszönen den weiblichen Ausdruck zu verleihen, gescheitert ist:

„Es war mir wichtig, den Blick auf das Obszöne nicht aus männlicher, sondern aus weiblicher Sicht zu zeigen. Ich wollte eine weibliche Sprache für das Obszöne finden und bin darauf gekommen, dass es nicht geht, weil es für eine Frau überhaupt nicht vorgesehen ist, über Sexualität zu sprechen. Ich habe gemerkt, dass es für eine Frau nicht möglich ist, darüber zu sprechen, ohne in die Sprache der Männer zu fallen.“374

\footnotetext{
${ }^{369}$ Ina Hartwig, a.a.O., S. $235 f$.

${ }^{370}$ Vgl. ebd.

${ }^{371}$ D.i. die literarästhetische Handhabung/Konzipierung der Sprache des Sexuellen.

${ }^{372}$ Ebd., S. 247.

${ }^{373}$ Vgl. ebd.

${ }^{374}$ Anja Meyer, a. a. O., S. 123. Die Konsequenzen dieses gescheiterten Versuchs werde ich im dritten Kapitel thematisieren. Ganz am Anfang ihrer Arbeit an Lust formuliert Jelinek genau ihre Absicht: „In dem Projekt, an dem ich beginne zu arbeiten, geht es darum, eine ästhetische Methode für das Obszöne, für Pornographie zu finden, was Frauen sehr selten getan haben, mit einer großen Ausnahme: Der Geschichte der O., die einzig literarisch bedeutende Pornographie von einer Frau, die ich kenne. Meine Arbeit wird ein Gegenentwurf zur Geschichte des Auges von Bataille sein. Dies impliziert eigentlich schon, dass es ein literarischer Text werden wird - seriös, ästhetisch gearbeitet und keineswegs Pornographie [Hervorhebung - K.S.] Dabei wäre es wichtig,
} 
Dieses Gestehen eines gescheiterten Schreibwunsches mag einerseits die Klassifizierung von Lust als pornografisch erleichtern, denn wenn Jelinek ein ,Anti-Porno' konstruieren wollte, musste sie doch zuerst das bestehende Pornovokabular nutzen, um es dann einem Prozess von strategischen de(kon)struierenden Modifikationen zu unterziehen. Wenn die Autorin jedoch gesteht, dass sie es nicht geschafft hat, heißt das, dass die bestehende Pornosprache nicht erfolgreich, d.h. um den weiblichen Ausdruck zu schaffen, modifiziert wurde. Die Sprache bleibt eine pornografische Sprache und stellt den männlichen Blick auf das Sexuelle dar. Andererseits müssen aber Jelineks Eingriffe und Attacken auf den herrschenden Blick irgendwo sichtbar/irgendwie wahrnehmbar sein, selbst an der Textoberfläche müssen sich doch Spuren (irgend)einer unterlaufenden Tätigkeit lokalisieren lassen. Werden solche Spuren gefunden, werden sie gern als anti-pornografische Momente des Romans gedeutet. Tom Mustroph macht z.B. auf die Übertreibung aufmerksam, die alle Sexualhandlungen in Lust begleitet: „Zu nackt, zu stählern tritt in Lust die Apparatur des Begattens zutage. Da ist kein Begehren mehr, keine Verführung, keine Erlangung des Einverständnisses mehr, wie sie wenn auch in meist rudimentärer Weise - in den meisten pornographischen Produkten [...] üblich ist. “375

Destruktiv auf das Pornografische sollten auch Satire und Groteske wirken. Schlich entdeckt „die satirische Brechung des Musters pornographischer Erzählung in Lust [...] in dem Satz [...]: ,Der Mann erscheint in der Früh als die nackte Wahrheit und reißt die Frau um. ' (L, 37) In Lust wird nicht die Frau als ,nackte Wahrheit' erotisiert, sondern werden Mann und Frau als ,die nackte Wahrheit‘ dämonisiert.“376 Die satirische Überspitzung fungiert in Lust, wie es Christiane Rasper bemerkt, nicht nur als ein ästhetisches Darstellungsmittel, sondern bringt stets auch ein Urteil zum Ausdruck. Indem Jelinek die pornografischen Sprechweisen imitiert, hat sie zum Ziel, ,auf dem Boden dieses Herrschaftsdiskurses denselben mit satirischen Mitteln ins Groteske zu verzerren, ihn bis zur Kenntlichkeit zu entstellen und damit seine Definitionsmacht zu verwerfen. “ ${ }^{377}$ Rasper weigert sich, eine klare Entscheidung zu treffen, ob Lust ein pornografischer Roman sei oder nicht. Sie bemerkt zwar, dass , die grotesken und makaberen Körperinszenierungen [...] die subkutane Struktur von Pornographie [symbolisieren, aber] dort geht es nicht um eine

den Blick auf den weiblichen Körper, auf das Obszöne nicht den Männern zu überlassen. " Gabriele Presber, Die Kunst ist weiblich, München 1988, S. 108f. Ich finde es interessant, dass obwohl sich Jelinek durch zwei pornographische Romane inspirieren ließ und durch ihre Lektüre die Kenntnis gewonnen hat, wie sie den Sexus nicht konzipieren soll, beurteilt ihren Versuch in Lust trotzdem als misslungen.

${ }^{375}$ Tom Mustroph, a. a. O., S. 111.

${ }^{376}$ Jutta Schlich, a. a. O., Fn. 40, S. 46.

${ }^{377}$ Christiane Rasper, a. a. O., S. 125. 
Variante von Sexualität, sondern um die systematische Verdinglichung der Frau im Interesse

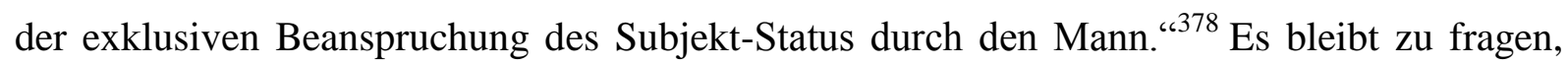
inwieweit die Satire, Ironie und Groteske den pornografischen Charakter des Textes subvertieren, denn ,eine Pornographie kann sich nicht selbst parodieren [...] Eine Parodie der Pornographie bleibt immer eine Pornographie.“379

Jelinek ist tatsächlich - wie sie auch selbst gesteht - daran gescheitert, die weibliche Lust in dem männlichen Sexualdiskurs affirmativ zur Sprache bringen zu wollen. ${ }^{380}$ Die negativen, subvertierenden Strategien der Satire und der Groteske blieben ihr als die einzige Möglichkeit, die pornografische Sprache der Männer anzugreifen. Ob „Ironie, Spott, Sarkasmus und Groteske als Sprengsatz für herrschende Diskurse ${ }^{\text {‘381 }}$ fungieren können, wie es Rasper schlussfolgert, bleibt fraglich. Für den männlichen Diskurs sowie für die Sprache der Pornografie gibt es keine Alternative, sie müsste erst erfunden werden. Literarästhetisch kann jedoch der herrschende, somit auch der pornografische Diskurs sehr wohl subvertiert werden. Inwieweit man ihn aber durch ästhetische Eingriffe entstellen, zersetzten oder karikieren kann, bleibt umstritten.

\footnotetext{
${ }^{378}$ Ebd., S. 130.

${ }^{379}$ Susan Sontag, (zit. nach Günther A. Höfler, a. a. O., S. 167.)

${ }^{380}$ Siehe Zitat 373, S. 104.

${ }^{381}$ Vgl. Zit. 377., S. 105.
} 


\title{
4.3. Lust und ,Weiblich(keit)' schreiben
}

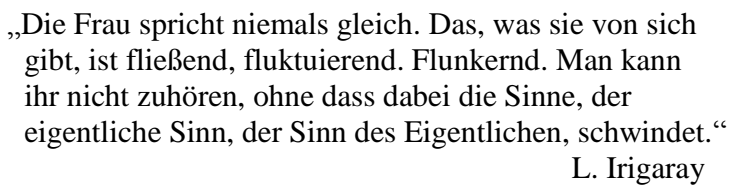

Ihre Arbeit am Roman Lust machte Jelinek mit folgender Ankündigung bekannt:

\begin{abstract}
„Zurzeit arbeite ich an einer Art erotischem Roman - ich sage nicht Porno -, einem weiblichen Gegenentwurf zur Geschichte des Auges von Georges Bataille. Ich versuche hier das weibliche Begehren zu thematisieren, das sich niemals realisieren kann, weil es sich nur in seiner eigenen Auslöschung realisieren lässt. Die Tragik, dass nichts möglich ist zwischen Männern und Frauen, weil das eine Begehren immer das andere zum Verlöschen bringt und eigentlich nicht steigert. Die weibliche Lust lässt sich, zusammen mit dem Mann, nicht realisieren. “382
\end{abstract}

Hinweise zu ihrem Roman formuliert Jelinek mehrmals, sowohl vor als auch nach dem Erscheinen des Buches, ihre Kommentare scheinen dabei den Stand der Dinge zu skizzieren, gestehen dann das Misslingen des Versuchs und suchen die Schuldigen des gescheiterten Projektes zu benennen. Allem Anschein nach ist es der Lust-Autorin nicht gelungen, ein antipornografisches Werk zu schreiben, in dem der männliche Blick auf den Körper durch den weiblichen (ab)gelöst/gelöscht werden könnte. Sie hat es nicht geschafft, den Sexus weiblich zu thematisieren, sie hat auch keinen Ort gefunden, von dem Weiblichkeit autonom geschrieben werden könnte. Angesichts dieses Scheiterns sollten jedoch Momente des Jelinekschen Versuchs untersucht werden, die Spuren und Reste, die von ihrem Kampf gegen den männlichen Diskurs zeugen, lokalisieren und Effekte dieses Kampfes feststellen lassen. Diese Momente werden meines Erachtens zu Orten, an denen eine tiefe, strategisch eingesetzte Subversion am Werk ist. Ihr Ziel - den männlichen Blick zu de(kon)struieren wird in Versuchen seiner Deformation, Entstellung, Verschiebung, Verunreinigung und Lockerung sichtbar. Einer Deformation wird vor allem die Sprache der Sexualität unterzogen, die nur aus dem männlichen Blick verbalisierbar ist. Zersetzt wird dabei die Subjekt-ObjektBeziehung, verschoben der Sinn, die Deutung, die Intention, hervorgebracht der Assoziationswahn.

\footnotetext{
${ }^{382}$ Sieglinde Kletterhammer, Welcome to Pornotopia? Literarische Sexualästhetik und Skandal seit 1968, in: Stefan Neuhaus und Johann Holzner (Hg.), Literatur als Skandal. Fälle-Funktionen-Folgen, Göttingen 2007, S. $420 f$.
} 
Es wurde zu Recht betont, dass Jelinek ihre weibliche Figuren nicht einfach als Opfer darstellt, „vielmehr wendet sich dieser kalte analytische Blick auf die eigenen Geprägtheiten, auf den unauflöslichen Zwiespalt, in dem eine intellektuelle schreibende Frau, ist sie nur ehrlich genug, in unserer Gesellschaft steht. ${ }^{\text {(383 }}$ Eine Schriftstellerin, die in der Sprache die weibliche Position besetzen will, wird sofort mit der Schwierigkeit konfrontiert, dass es im Symbolischen keinen Ort für das Weibliche gibt. Wie ist aber diese seltsame Feststellung zu verstehen und was heißt es für eine schreibende Frau? Um den Gedanken richtig zu verstehen und seine Überzeugungskraft und Konsequenzen einschätzen zu können, müssen zunächst die Annahmen belichtet werden, auf Basis deren jene Idee hervorgebracht wurde. Es gibt kaum Theoretiker, deren Einfluss auf den feministischen Diskurs so inspirierend und provozierend zugleich wäre wie der Jacque Lacans. Seine Behauptung, „Mann und Frau meinen [...] nicht mehr biologisch-anatomische [...], sondern diskursive [Positionen]. Positionen also, die ausschließlich durch das (symbolische) Gesetz, die Sprache strukturiert sind ${ }^{\text {“384 }}$, eröffnete ein neues Kapitel in der feministischen Diskussion. Lacan zufolge

„konstituiert der Phallus, d.h. die Abwesenheit des männlichen Geschlechts am Körper der Frau, die Symbolische Ordnung. Das Symbolische, das sich so auf ein (negatives/abwesendes) männliches Zentrum beruft, ist unfähig, andere Ströme als eine männliche Bedeutungsökonomie zu erfassen. Vielmehr kann das, was ,anders“ ist, z. B. das Weibliche, nur als Abwesenheit (des männlichen Geschlechts) bzw. die Frau als ,negative Andere des Mannes ${ }^{\text {‘35 }}$ gefasst werden. “386

Eine schreibende Frau müsste daher, um sich im herrschenden Diskurs ausdrücken zu können, die männliche Position für sich anmaßen, ,benutzt sie allerdings dieses männliche Instrument, um weibliche Probleme zu diskutieren, so stellt sich die Frage nach der Korrumpierung der Intention durch das Mittel[...] $]^{6387}$, „[w]eil es für die Frau bzw. für das weibliche Geschlecht im Symbolischen keine Entsprechung gibt, kann über sie von der Position des Universellen aus nur gebarrt, gesperrt, durchgestrichen gesprochen werden $[\ldots]^{6388}$

\footnotetext{
${ }^{383}$ Sigrid Schmid-Bortenschlager, Der analytische Blick, in: Carine Kleiber und Erika Tunner (Hg.), Frauenliteratur in Österreich von 1945 bis heute, Bern Frankfurt am Main New York 1986, S. 126.

${ }^{384}$ Nicole Masanek, a.a.O., S. 23.

385 Diese Bezeichnung stammt von Ingeborg Weber, aus dem Aufsatz Den Bahn der patriarchalen Spiegel-Logik brechen, dem weiblichen Begehren eine Chance: Luce Irigaray und das Konzept des ,parler femme', in: Ingeborg Weber (Hg.), Weiblichkeit und weibliches Schreiben. Poststrukturalismus. Weibliche Ästhetik. Kulturelles Selbstverständnis., Darmstadt 1994, S. 34.

${ }^{386}$ Ebd., S. 27f. In Anlehnung an das Freudsche Konzept des Ödipuskomplexes versucht Masanek die sehr komplizierte und verwirrende Theorie Lacans verständlich zu machen und ihre Bedeutung für den feministischen Diskurs zu sondieren. Die psychoanalytischen Theorien, sowohl die Freudsche als auch die Lacansche, schätzt sie als sehr wertvoll für die feministische Forschung ein.

${ }^{387}$ Sigrid Schmid-Bortenschlager, a.a.O., S. 126.

${ }^{388}$ Nicole Masanek, a.a.O., S. 32.
} 
Um das Weibliche in Lust überhaupt aufspüren zu können, müssen wir aber zuerst die Kenntnis darüber gewinnen, wie die Weiblichkeit in der Schrift fassbar und beschreibbar wäre. In der feministischen Forschung wurden bis jetzt einige Ansätze ausgearbeitet, die für die Analyse der literarisch-weiblichen Ästhetik hilfreich sein könnten.

Die einflussreichsten Versuche der Ausarbeitung der weiblichen Ästhetik liefern drei französische Geisteswissenschaftlerinnen: Luce Irigaray, Hélène Cixous und Julia Kristeva. Weil sich ihre Ansätze sowohl inhaltlich als auch in der Präzision der Ausführungen voneinander sehr unterscheiden, werde ich ihre Konzepte vergleichend skizzieren und zwar mit dem Ziel ihren praktischen Wert für die Analyse literarischer Texte zu sondieren. Alle drei Theoretikerinnen lehnen sich in ihren Arbeiten an die psychoanalytischen Theorien Freudscher und Lacanscher Provenienz an und versuchen diese zu überwinden, indem sie in literarischen Texten „nach Repräsentationsformen des Weiblichen [suchen]. Sie suchen nach in der Sprache versteckten Elementen, Strukturen und Bewegungen, die als spezifisch weibliche gefasst werden können, um dann das theoretisch zu verankern, was bereits in humanistisch orientierten Feminismus immer wieder proklamiert wurde: eine spezifisch weibliche Ästhetik. “389

Am meisten metaphorisiert und somit unpräzise konzipiert ist das Projekt von Hélène Cixous. Diese französische Feministin assoziiert, ecriture feminine' mit dem körpernahen Sprechen, das ähnlich dem Unbewussten „grenzenlos, verströmend, überfließend ist.““390 Anders als das männliche vom Körper entfremdete Sprechen zeigt sich das weibliche durch seine Subversivität: „A feminine text cannot fail to be more than subversive. It is volcanic; as it is written, it brings about an unheaval of the old property crust, carrier of masculine investments." 391 Das Problem des eindeutigen Bestimmens des spezifisch Weiblichen resultiert bei Cixous aus der Annahme, dass das Subjekt nicht primär biologischgeschlechtlich determiniert sei. Die Schlussfolgerung aus dieser Annahme kann dann die Möglichkeit nicht ausschließen, „dass auch Männer, wenn sie den Zugang zum KörperlichImaginären finden, weiblich-subversiv schreiben können.““392 Das Problem ist mit einer allgemeineren Frage eng verbunden, die bis jetzt nicht beantwortet werden konnte und zwar: $\mathrm{Ob}$ sich in Texten schreibender Frauen Momente lokalisieren lassen, die nur in Texten der

\footnotetext{
${ }^{389}$ Ebd., S. 11.

${ }^{390}$ Nicole Masanek, a. a. O., S. 41.

${ }^{391}$ Hélène Cixous, The laugh of the Medusa, in: Signs, Vol. 1, No. 4, Chicago 1976, S. 888, zit. nach Masanek, a.a.O., S. 41.

${ }^{392}$ Nicole Masanek, a. a. O., S. 41. Eine weitere Schwäche dieses Konzeptes entdeckt Ricarda Schmidt, indem sie schlussfolgert, „dass Cixous als > weiblich< ausgebe, was zum historischen Stilkanon der Romantik gehöre." Johanna Bossinade, Poststrukturalistische Literaturtheorie, Stuttgart Weimar 2000, S. 75.
} 
Frauen auffindbar seien? Sollte die Frage bejaht werden, würde es einen Meilenschritt in die Richtung der Fixierung der Merkmale der weiblichen Ästhetik bedeuten.

Luce Irigaray möchte im Weiblichen einen Gegen-Diskurs zum männlichen Symbolischen sehen und „situiert dementsprechend statische Momente (wie z.B. Blick, Form und Ordnung) auf der Seite des Mannes, während die Berührung, der (Über)Fluss und die Bewegung der Frau zugesprochen wird. “393 Der Einheit des Mannes werden die ,Vielheit‘ und ,Doppelheit“ der Frau gegenübergestellt, aus dieser Trennung leitet Irigaray das Wesen der Weiblichkeit ab: „So wie die beiden Schamlippen sich weder als Einheit noch als Zweiheit beschreiben lassen, so ist die Frau selbst ${ }^{\star 394}$,weder eine noch zwei. Bei aller Anstrengung kann sie nicht als eine Person, noch auch als zwei bestimmt werden. Sie widersteht jeder adäquaten Definition.“395 Scheint das Irigaraysche Konzept auf den ersten Blick neuartig ausformuliert zu sein, so macht Nicole Masanek auf die Verwirrung aufmerksam, wenn man klarstellen möchte „,inwieweit das Irigaraysche Denken ein biologisch-substanziell determiniertes ist.“ 396 Untersucht man Irigarays Texte mit dem Ziel, das spezifisch Weibliche herauszupräparieren, so stellt man sich vor die Unsicherheit, wie die französische Feministin Begriffe wie ,Frau“, ,weiblich', ,Geschlecht' liest. Zahlreiche Stellen ihrer Texte lassen nach Masanek schlussfolgern, dass Irigaraysche Weiblichkeit letztendlich auf den Körper reduziert wurde ${ }^{397}$, es gibt aber auch Stellen, die vermuten lassen, dass sie die oben genannten Begriffe, durch ihren Gebrauch in Anführungsstrichen eher strategisch und temporär einsetzt. ${ }^{398}$ Obwohl die Irigaraysche Bestimmung der Weiblichkeit nicht scharf genug konzipiert wurde, liefern ihre Untersuchungen der weiblichen Sexualität viele Beobachtungen, die für die literaturwissenschaftliche Arbeit am Problem der Weiblichkeit nutzbar gemacht werden könnten. Irigaray betont mehrmals, dass Frauen einer anderen sexuellen Ökonomie folgen als die Männer, „dass ihre Beziehung zum Fließenden und zum Festen, zur Materie und zur Form, zum Berühren - durch Haut und Schleimhäute - zur Symmetrie, zu Wiederholungen etc. anders sind. ${ }^{6399}$ Die Form der Sexualität muss eine andere als die der Männer sein, vor allem aus dem Grund, dass die erste durch Geschehnisse determiniert ist, „die eine viel

\footnotetext{
${ }^{393}$ Ebd., S. 38.

394 Ebd.

395 Luce Irigaray, Das Geschlecht das nicht eins ist. Berlin 1979, S. 25.

${ }^{396}$ Nicole Masanek, a. a. O., S. 39.

${ }^{397}$ Vgl. ebd., S. 40.

${ }^{398}$ Vgl. ebd., S. 39.

${ }^{399}$ Luce Irigaray, Genealogie der Geschlechter, Freiburg 1989, S. 311.
} 
kontinuuierlichere Zeitlichkeit markieren als die Einschnitte in der männlichen Sexualität bzw. deren Kontinuität, die keine unumkehrbaren Entwicklungen kennt.، “400

Unter die Lupe nimmt Irigaray auch die Lusterfahrung der Frau, die im Gegensatz zu dem Mann zwei Arten der Lustwahrnehmung kenne. Die erste Art, man möchte sagen - die falsche Lust -, sei nach einer männlichen Libido-Ökonomie vorprogrammiert ${ }^{401}$ und scheint der Frau eher aufgeworfen zu sein. Diese männliche Lust werde in einer überspitzten Form in der Pornografie realisiert:

„In der Pornographie kommt ein frauenspezifisches Begehren nicht vor. [...] Diese Zwangsvorstellung, diese Fixierung allein auf den Penis und die Erektion, diese stereotypen Bilder, das endlose Abspulen eines immer gleichen Programms, das Mechanische an einer Szene, die keine - unnötigen? - neuen Gesten erfindet und nur vorhersehbare - leblose? Bewegungen zeigt, das alles sagt Frauen nicht sonderlich zu. Das Bewegliche, das Wechselnde, das Fließende berührt sie mehr.“402

Die frauenspezifische Lust scheint sich dann erst in der Negation und durch das Auslöschen der männlichen Lust realisieren zu können, weil sich die Koexistenz beider Lustarten nicht gleichzeitig erleben lasse. Die Lust der Frau muss sich daher der fixierenden Beschreibung entziehen, indem sie doch der Lust des Mannes keine autonome Wahrnehmungsweise entgegenstelle, sondern erst ab dem Punkt des Auslöschens der männlichen Begierde denkbar sei. Soll nach Irigaray „das Bewegliche, das Wechselnde, das Fließende [...] Das nicht in einmaligen, endgültigen Formen befangene Werden“"403 die Frau berühren, so scheint die weibliche Lust noch keinen Ort für sich gefunden zu haben. Irigarays Suche nach der Form der weiblichen Ästhetik sowie nach dem Bestimmen der weiblichen Lust bringt, mehr oder weniger direkt, eine Inkompatibilität der männlichen und weiblichen sexuellen Ökonomien hervor. Diese Unmöglichkeit einer gleichzeitigen Entfaltung männlicher und weiblicher Begierden ist in ästhetisch überspitzter Form in Jelineks Lust präsent. Ähnlich wie Irigaray versucht Jelinek im „erneute(n) Durchqueren des Diskurses [...] einen Ort des ,Weiblichen“ wiederzufinden.“ ${ }^{404}$ Dieses (Wieder)Finden, diese „Wiederaufnahme des Weiblichen ins Innere einer Logik, die es in der Verdrängung, unter der Zensur, genauer in der Verkennung festhält “ ${ }^{405}$, muss jedoch als ein paradoxes Unterfangen unternommen werden, während

\footnotetext{
${ }^{400}$ Ebd., S. 311.

${ }^{401}$ Vgl. ebd., S. 45.

402 Luce Irigaray, Zur Geschlechterdifferenz, Wien 1987, S. 31 u. 36.

${ }^{403}$ Ebd., S. 36.

${ }^{404}$ Luce Irigaray, Das Geschlecht das nicht eins ist. Berlin 1979, S. 80.

${ }^{405}$ Ebd.
} 
dessen eine Entität oder eine Bewegung aufgespürt werden soll, die es vielleicht gar nicht gibt oder deren Form sich in der gegebenen Sprache nicht ausdrücken lässt. Das Bewusstsein dieser paradoxen Suche zeigt sich bei Irigaray im Verzicht auf die Konstruktion einer Theorie der Weiblichkeit. Ähnlich wird sich Jelinek im Laufe des Lust-Entstehens allmählich dessen bewusst, dass sie eine Affirmation der weiblichen Lust literarästhetisch nicht kreieren kann. Einer Mission ähnlich macht sich Irigaray auf den langen Weg ins Innerste des herrschenden Diskurses und alle Sinne aktivierend, entfaltet sie eine Strategie, mit der sie „die Weise interpretierend-wiederholend, in welcher im Inneren des Diskurses das Weibliche sich determiniert findet: als Mangel, als Fehlen, oder als Mime und verkehrte Wiedergabe des Subjekts ${ }^{\text {‘406 }}$ kundtut.

Im Gegensatz zu Hélène Cixous und Luce Irigaray nähert sich Julia Kristeva dem Phänomen der Weiblichkeit sehr vorsichtig und skeptisch. Die Privilegierung der männlichen Perspektive auf das Geschlechtliche will sie gar nicht in Frage stellen und scheint auch nicht dieses Privileg unterlaufen zu wollen. $\mathrm{Zu}$ dem Weiblichen (er)findet sie einen gar originellen Pfad, indem sie die psychoanalytischen Paradigmen raffiniert lockert und so Lücken entstehen lässt, in denen die weibliche Ästhetik aufkeimen könnte. Kristeva wiederholt Lacans These, „der Eintritt in die (väterliche) Sprache geht einher mit einer notwendigen Verdrängung der ersten Mutterbindung, mit einer Verdrängung des der Sprache vorgängigen Semiotischen zugunsten der Symbolischen Ordnung. “" ${ }^{407}$ Sieht Lacan diese Verdrängung als unwiderruflich,

\footnotetext{
${ }^{406}$ Ebd. Einen wichtigen Punkt erreicht Irigaray, indem sie die Frage: Was ist die Frau? verwirft und ihr Projekt nicht in der Konstruktion eines Entwurfs des Weiblichen, der mit dem Entwurf des Männlichen rivalisieren sollte, entfaltet. Durch diese Strategie schrumpft zwar das spezifisch Weibliche zu einem, ver-rückenden Exzess', es bleibt aber konsequent dem ,Onto-Theo-Logischen' weit entfernt. Vgl. ebd., S. 80.

Bossinade sieht die Schwäche des Ansatzes Irigarays in der Verwerfung der Aufgabe, „das Negative bzw. den Mangel präziser auszuarbeiten, wo es um die Bedingungen der geschlechtssymbolischen Position von Frauen geht. Andernfalls bleibt den Bildern des Weiblichen in der Tat nur ein ebenso großer oder geringer Erklärungswert, wie man inn dem Ort der Frau als >Nicht<, >Anders< oder >lenseits< des Phallus zusprechen kann." Johanna Bossinade, a.a.O., S. 71. Als Alternative für die Verwerfung dieser Aufgabe würde ich Irigarays Idee der ,zweiten Syntax' sehen, die die konsequente Subversion des herrschenden Wissensdiskurses zum Ziel hat, indem „Konstruktionen, Dispositive, Szenographien“ dieses Diskurses „auf enthüllende Weise“ wiederholt werden. „Das mimetische Wiederholen, das Nachplappern verzerrt, vexiert, karikiert den pietätvollen Ernst wissenschaftlicher Theorie." Luce Irigaray, Speculum, Frankfurt am Main 1980, S. 471.

${ }^{407}$ Nicole Masanek, a.a.O., S. 44. Masanek führt hier Kristevas Analysen aus ihrem Buch Die Revolution der poetischen Sprache an.

Leider liefert weder die Freudsche noch die Lacansche Psychoanalyse zufriedenstellende Ergebnisse aus dem Feld der Weiblichkeitsforschung. Freud war sich dessen völlig bewusst, dass seine Psychoanalyse dem Rätsel der Frau nicht gewachsen sei. (Vgl. Edith Seifert, >Was will das Weib? $<Z u$ Begehren und Lust bei Freud und Lacan, Weinheim und Berlin 1987, S. 75f.) Lacans Verdienst ist, dass er auf das Genießen der Frau aufmerksam gemacht hat, obwohl auch auf sehr knifflige Art und Weise: „Zum weiblichen Genießen gehört es dazu, dass es fehlt und dass die Frau, von der Natur der Dinge, d.h. der Worte, ausgeschlossen ist, so dass sie nicht sagen kann, worin der Gegenstand ihres Genießens besteht. [...] Das Genießen der Frau entwischt dem phallischen, dem sprachlichen Register. [...] Im Genießen enthülle sich ihr ein Wissen von eigentümlicher Art, ein Wissen, das nur im Vollzug gegeben ist und sich ansonsten nicht weiß." Edith Seifert, a.a.O., S. 155f. Unverständlich
} 
„so betont Kristeva, dass auch nach Eintritt in die Sprache das verdrängte, präödipale Semiotische in Form von Verwerfung, Entgrenzung oder gar Zerstörung des thetischen Symbolischen immer wieder, und besonders in literarischen Texten, in Erscheinung tritt. Die Eingriffe des Semiotischen ins Symbolische lassen die von letzterem hergestellte vermeintliche - Einheit des Sinns auseinanderbrechen“408 „und so dessen Theologisierung überschreiten $[\ldots]^{\text {‘ } 409}$

Die Schwierigkeit in dem Konzept Kristevas (im Kontext der Bestimmung der weiblichen Ästhetik) liegt in der Tatsache, dass sie das Semiotische nur indirekt und locker mit dem Weiblichen verbindet. Anders als Cixous und Irigaray weist sie auch die Möglichkeit einer spezifisch weiblichen Schreibweise zurück. ${ }^{410}$ Ohne Zweifel liefert Kristeva und ihr ,dekonstruktiver Feminismus' einen interessanten und ausgeklügelten Ansatz zum Problem der weiblichen Ästhetik. Ihr skeptisches Vorgehen ist Ausdruck einer eher kalten und nüchternen Einschätzung der Lage der feministischen Forschung, die oft affirmativeuphorisch das Weibliche dem Männlichen entgegenzustellen sucht. Der ,dekonstruktive Feminismus“ wird nicht mehr danach fragen, wie „sich die an einer genau bestimmbaren Position situierte Frau definieren und beschreiben“ [lasse, sondern] „wie produziert sich dieser Signifikant, den wir , weiblich` nennen, innerhalb der binär ausgerichteten Ordnung des Symbolischen. ${ }^{\text {“411 }}$

Lassen sich Irigarays ,Durchqueren des Diskurses ${ }^{6}$ und Kristevas Hervorbringung des Semiotischen in einer mehr oder weniger präzisen Bilanz der theoretischen Gewinne und Verluste/Verzichte zusammenfassen, so bleibt das Ergebnis der Jelinekschen Konfrontation mit der Frage der weiblichen Lust weiterhin im Dunklen. Die Ideen der französischen Forscherinnen liefern zwar originelle, bildhafte und rhetorisch raffinierte Annäherungsversuche an das Geheimnis des Weiblichen, ihr Erklärungspotential für die durch die LustLektüre gestifteten Verwirrungen, zeigt sich jedoch als sehr beschränkt.

Auch im deutschen Sprachraum versuchte man im Rahmen der feministischen Forschung, sich diskursiv dem schwierigen Problem der weiblichen Ästhetik anzunähern, indem die Ideen

\footnotetext{
bleibt jedoch Lacans Beitrag zum Rätsel der Weiblichkeit ohne Kenntnis seiner Theorie des Signifikanten und seiner neuartigen Fortsetzung Freudschen Analysen. In seinem berühmten Seminar über Edgar Poes Der entwendete Brief illustriert Lacan die Schwierigkeiten des Bestimmens der weiblichen Lust. (Eine detaillierte Analyse dazu liefert Edith Seifert, a.a.O.)

${ }^{408}$ Masanek a.a.O., S. 44.

${ }^{409}$ Julia Kristeva, Die Revolution der poetischen Sprache, Frankfurt am Main 1978, S. 70.

${ }^{410} \mathrm{Vgl}$. Masanek a.a.O., S. 45. Weber bemerkt zu Recht, dass „das, was Hélène Cixous und Luce Irigaray als essentiell weibliches Diskursverfahren reklamieren, [sich] als ein essentiell poetisches Diskursverfahren entpuppt." Ingeborg Weber, Modernität, Marginalität, Mutterschaft: Die Stimme der Julia Kristeva zu Weiblichkeit und weiblichem Schreiben, in: Ingeborg Weber (Hg.), a.a.O. , S. 40.

${ }^{411}$ Masanek a.a.O., S. 55.
} 
der Französinnen weiter bzw. anders gedacht wurden. Einige der in diesem Kreis herausgearbeiteten Konzepte scheinen auch m. E. den Nerv der in Lust eingesetzten Verwirrungsstrategien theoretisch punktuell zu treffen. Diese möchte ich im Folgenden kurz darstellen.

Für den Anfang einer kurzen Übersicht bieten sich informative Behauptungen über die Weiblichkeit von Barbara Lersch an:

„,Weiblichkeit‘ negiert den Kanon logozentrischer Zurichtungen kulturellen Wissens, der ideengeschichtlich mit dem Mann konnotiert ist. Aber sie tut dies nicht, indem sie sich diesem kategorisch und gewissermaßen aus dem Nichts als dichotomische Gegen-Rede gegenüberstellt. Vielmehr erfordert es ihre Kritik an der repräsentativen Logik, dass sie sich selbst in den Prozess der Zurichtungen, gegen den sie Einspruch erhebt, einbezieht: als das Bild der Frau, das auch als das per se ,ganz Andere, das Nicht-Definierte', Anteil hat an einem substantialisierenden Denken, das niemals ganz ohne Grenzsetzungen auskommen wird.“412

Dieser Beschreibungsversuch, sei es ziemlich abstrakt in seiner Ausformulierung, scheint schon zwei wichtige Momente der Idee der Weiblichkeit zu thematisieren: Erstens wird das Weibliche als Negation begriffen, zweitens soll diese Negation nicht im Sinne einer ,dichotomischen Gegen-Rede‘ konzeptualisiert werden. Das so definierte Weibliche wäre jedoch praktisch kaum vorstellbar, es wäre nämlich sehr schwierig, eine Ästhetik zu konzipieren, die erstens den herrschenden, männlichen Diskurs effektiv subvertiert, die zweitens nicht als Gegen-Diskurs begriffen wird und die drittens dem spezifisch Weiblichen einen Ausdruck verleiht. Somit muss zuerst untersucht werden, ob das Projekt, Weibliche Ästhetik' mehr als eine ,theoretische Fiktion “413 hervorbringen kann:

„Als eine Projektion und ein Projekt, nicht aber als empirische Textgattung ,Frauenliteratur', ist ,weibliche Ästhetik‘ für Lachmann Bestandteil eines Diskurses, den sie auch, inoffiziell‘ und ,spekulativ‘ nennt. Darum, sagt sie, könne man die ,inoffizielle, subversive, avantgardistische Schreibweise“ auch als, weiblich' bezeichnen, weil sie“4114 „diejenige ist, die von Frauen ganz zu der ihren gemacht und ausgebaut werden könnte, und zwar aufgrund ihrer geschlechtsspezifischen Erfahrungen, wozu vor allem die Formerfahrung gehört.““415

\footnotetext{
${ }^{412}$ Barbara Lersch, Der Ort der Leerstelle. Weiblichkeit als Poetik der Negativität und der Differenz, in: Gisela Brinker-Gabler (Hg.), Deutsche Literatur von Frauen Bd. 2, München 1988, S. 494.

${ }^{413}$ Renate Lachmann, Thesen zu einer weiblichen Ästhetik, in: Claudia Opitz (Hg.): Weiblichkeit oder Feminismus? Weingarten 1984. S. 191.

${ }^{414}$ Barbara Lersch, a.a.O., S. 495.

${ }^{415}$ Renate Lachmann, a.a.O., S. 183.
} 
Lachmanns Reflexion über die weibliche Ästhetik findet für sie einen Ort in etwas bereits Existierenden. Unklar bleibt jedoch, in welcher Beziehung das Weibliche als ,Bestandteil eines Diskurses` zu diesem Diskurs begriffen und welche subversive Wirkung dem spezifisch Weiblichen zugeschrieben werden darf. Desweiteren versucht Lachmann den Metonymiebegriff zu erweitern und die Weiblichkeit mit dem metonymischen Schreiben zu verbinden: „,Weiblich` kann in diesem Zusammenhang eine Ästhetik genannt werden, die an vorgefundene Formpraktiken - also etwa auch: Poetiken - anschließt, aber weder so, dass sie sich ihnen assimiliert, noch so, dass sie sich ihnen hinzufügt, sondern indem sie sich ihrer bedient und ihnen Platz nimmt, ohne damit die Repräsentation eines hypostasierten Sinnkonzepts mitzuübernehmen. Lachmann zufolge gelingt dies der metonymischen Schreibweise über eine metapoetische Reflexion, mittels derer der ,Anschluss des Schreibens als Handlung an die Erfahrungen des Subjekts in die Struktur eines Textes eingeht. “416

Die metonymische Schreibpraxis lässt sich jedoch keinesfalls, darüber ist sich Lachmann natürlich im Klaren, als geschlechtsspezifisch bestimmen. ${ }^{417}$ Eindeutig scheint somit Lachmanns Strategie darauf zu beruhen, für das Weibliche Orte zu gewinnen, die bereits gefüllt sind. Die Füllung dieser Orte muss jedoch uneindeutig sein, ihre Lage im Verhältnis zum herrschenden Diskurs unklar und/oder unbestimmbar. Lachmann will kein Neuland entdecken, sie benennt eher das Bestehende um. An der Diskurskarte will sie keine neuen Grenzen anlegen, sie deutet lediglich die bereits existierenden Territorien neu. In diesen unterbelichteten Orten sollte „die konstruktive, in die Zukunft gerichtete Textarbeit“" starten, „im Abtragen der erstarrten Formen offizieller Kultur, in einer Arbeit des Zer-Setzens und Zer-Schreibens der herrschenden Diskurse, im Aufbau einer Schreibweise, die nichts sich fixieren, festsetzen, gerinnen lässt ${ }^{\text {“418 }}$, könnte die Frau eine Peripherie des Symbolischen kolonisieren, die sie allmählich zu einem Gegen-Diskurs entfalten würde.

Wesentlich skeptischer bei der Konzeptualisierung von Weiblichkeit ist Sigrid Weigel. Statt nach der Spezifik des Weiblichen zu suchen, listet sie zunächst Schwierigkeiten und Gefahren auf, die die Versuche des Bestimmens der weiblichen Ästhetik konsequent stören werden. Mit Skepsis begegnet Weigel vor allem der Idee - „,Weiblichkeit‘ als Gegenkonzept

\footnotetext{
${ }^{416}$ Barbara Lersch, a.a.O., S. 496.

${ }^{417}$ Vgl. Renate Lachmann, a.a.O., S. 188.

${ }^{418}$ Ebd., S. 189.
} 
zu profilieren, [die] Gefahr laufe, zu einer neuen Substantialität zu gerinnen: indem““419 „die Frau als Metapher für die metonymische Bewegung gesetzt wird. “420

„Weigel versteht darunter die Fixierung des ,Uneigentlichen“ in einer alten ontologischen ,Eigentlichkeit‘: dem ,Rätsel Weib“; und dem liegt für sie nach wie vor die ,Perspektive des Mannes“ zugrunde:“421 „Wegen der ambivalenten Beziehung der Frau zur Sprache, zum Symbolischen macht der Mann sie zum universellen Bild der Ambivalenz. “422

In dieser Optik wird aber die Perspektive der Frau zur „schreibende[n] Hervorbringung des Mangels bzw. der Negation“ ${ }^{\text {423. }}$. Diesen theoretischen Pessimismus wollten jedenfalls nicht alle Forscherinnen teilen. In ihrer abstrakten Konzeption des Weiblichen denkt Eva Meyer Weiblichkeit als ,Operation in der Sprache‘, als ,unabgeschlossenen Transformationsprozess‘ im Diskurs. ${ }^{424}$ Mit der Kategorie des ,Dritten“ führt Meyer die Auflösung des Diskurses ,über die Frau in eine diskursive Bewegung, die sich querlegt zur prädikativen und attributiven Logik der Sprache. Diese Bewegung kann nur über die gegebene

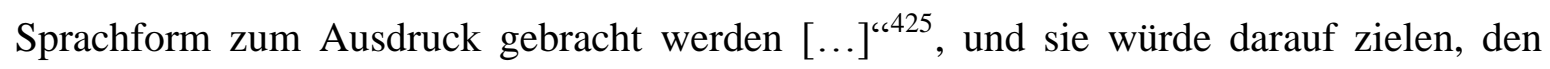
„ontologischen Ort des Nichts, den Schauplatz des Weiblichen wieder ins Spiel zu bringen, und zwar nicht als Negation, wie sie logischerweise eine Opposition, also eine Dichotomie artikuliert und somit phallisch reduzierbar ist. ${ }^{426}$ Diese höchst abstrakt konzipierte Form des Ausdrucks der weiblichen Ästhetik versucht Meyer mit der Stilfigur des Chiasmus zu verbinden. Wichtig ist der Moment, in dem ,die chiastische Überkreuzung zweier Antithesen [...] diese [...] nicht in einer geeinten Synthese positiv [aufhebt], sondern hält die negative Spannung, die zwischen ihnen besteht, lebendig: als Beunruhigung, prozessuales Wechselspiel, Bruch.“427

In der hohen Abstraktheit und Komplexität der oben skizzierten Entwürfe der weiblichen Ästhetik liegt die Schwierigkeit ihrer Applizierbarkeit auf konkrete literarische Texte. Den wirklichen Wert eines ausgeklügelten Entwurfs der Weiblichkeit würde ich vor allem da

\footnotetext{
${ }^{419}$ Barbara Lersch, a.a.O., S. 496.

${ }^{420}$ Sigrid Weigel, Die Stimme der Medusa. Schreibweisen in der Gegenwartsliteratur von Frauen, DülmenHiddingsel 1995, S. 212.

421 Barbara Lersch, a.a.O., S. 496.

${ }^{422}$ Sigrid Weigel, a.a.O., S. 213.

${ }^{423}$ Sigrid Weigel, Das Schreiben des Mangels als Produktion von Utopie, in: Friederike Hassauer, Peter Roos (Hg.), Die Frauen mit Flügeln, die Männer mit Blei?, Siegen 1986, S. 126.

${ }^{424}$ Vgl. Barbara Lersch, a.a.O., S. 500.

${ }^{425}$ Ebd.

${ }^{426}$ Eva Meyer, Vorspiel: Annäherung an eine andere Schreibweise, in: Brigitte Wartmann (Hg.), WeiblichMännlich. Kulturgeschichtliche Spuren einer verdrängten Weiblichkeit, Berlin 1980, S. 66.

${ }^{427}$ Barbara Lersch, a.a.O., S. $500 f$.
} 
suchen, wo das komplexe Konzept als Matrix und/oder Instrument für eine Textanalyse eingesetzt werden könnte, und wenn sich dadurch die Ergebnisse der Analyse plausibilisieren lassen. Bevor ich es versuche, die (Para)Logik der in Lust tobenden Subversionen offenzulegen, möchte ich zunächst einschätzen, inwieweit die skizzierten Konzepte einander ähneln. Den meisten von ihnen scheinen folgende Behauptungen gemeinsam zu sein:

„[...] die Interpretation von ,Weiblichkeit‘ als diskursivem, statt als empirischem Begriff; dessen Auflösung in eine Sprach- oder Denkform; seine Ableitung über eine Analogiebildung zum kulturgeschichtlichen Bild der abwesenden Frau; die Akzentuierung des ,Verqueren` und Nichtsagbaren in seinen logischen, psychoanalytischen und poetologischen Dimensionen; die Vorstellung einer verräumlichten Sprache als Gegenmodell zum linearen Denken; ein Verständnis von Sprache als Materialisierung des Körpers.“428

Die Benennung der Gemeinsamkeiten und Übereinstimmungen in den Konzepten der weiblichen Ästhetik hat m.E. eine nützliche ordnende Funktion. Weiterhin müsste man aber danach fragen, „inwieweit der Weiblichkeitsbegriff den Anschluss an eine Realdimension geschlechtsspezifischer Habitualisierungen wiedergewinnen könnte [... $]^{\text {‘429 }}$, und wie sich das Verhältnis zwischen dieser Realdimension und der in einem literarischen Text abgebildeten Realität erfassen ließe. Wegen ihrer starken Metaphorisierung stellen alle Konzepte der weiblichen Ästhetik eine große Herausforderung für die Literaturwissenschaft. Es ist unklar, welche Literaturtheorie die Weiblichkeit im Sinne eines geisteswissenschaft- lichen Begriffs fruchtbar handhaben könnte und wie sie als Poetik lesbar wäre, „wenn sie als Anti-Poetik gedacht ist und ihre wichtigste Kategorie die der Leerstelle - als Atopos der Negation und der Differenz - ist. “430

Das Schreiben gegen den herrschenden Diskurs, das sich jedoch innerhalb dieses Diskurses und mit den für ihn spezifischen Mitteln und Strukturen vollzieht, mag zuerst als paradox erscheinen. Wollen wir jedoch den Forscherinnen der weiblichen Ästhetik glauben, dass dieses Unterfangen doch innerhalb des Möglichen liege, brauchen wir erst eine klare Instruktion, was mit einem weiblich subvertierten Text und/oder Diskurs geschehen wird, wie wird seine beabsichtigte Destruktion sichtbar und als solche decodierbar. Wird die Weiblichkeit ideengeschichtlich mit Ambivalenz, Abweichung, Mangel und Verdrängtem ${ }^{431}$ assoziiert, so müssten auch diese Eigenschaften im Text oder genauer im Prozess der Lektüre irgendwie lokalisierbar und rezipierbar werden. Der Ort, den das Weibliche im Textuellen

\footnotetext{
${ }^{428}$ Ebd., S. 501.

${ }^{429}$ Ebd., S. 502.

${ }^{430}$ Ebd.

${ }^{431}$ Vgl. Inge Stephan, Feministische Literaturwissenschaft, Berlin 1984, S. 5.
} 
besetzt, sollte dem Ort entsprechen, an dem die Frau kulturgeschichtlich auffindbar war - als ein doppelter Ort, „der zugleich innerhalb, aber auch außerhalb der Kultur angesiedelt ist; als ein anwesendes Abwesendsein, das sich in Form einer besonderen Existenzweise mit eigenen Erfahrungs-, Wahrnehmungs- und Ausdrucksweisen zeigt. “432 Die Konzeption des doppelten Orts der Frau sollte meines Erachtens eng mit dem gleichzeitigen „Ein- und Ausschluss des

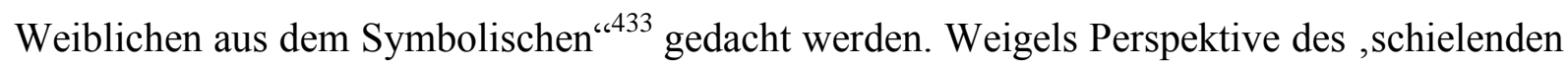
Blicks“ scheint den Gedanken zutreffend aufzufassen, indem sie bemerkt, „dass sich Frauen, um überhaupt schreiben und publizieren zu können, männlichen Denkmustern zwar anpassen müssen, ohne dabei allerdings die spezifisch weiblichen Momente in ihren Texten ganz verschwinden zu lassen.“ ${ }^{434} \mathrm{Um}$ das Charakteristische dieses doppelten Ortes überhaupt ausdrücken zu können, werden z.B. in den literarischen Texten originelle Kunstgriffe eingesetzt, wie „verdoppelnde Perspektiven, Anwendung und zugleich Zerstörung bestehender Genremuster, Beschreibung von Innen und Außen zugleich.“" 435 Abgesehen davon, inwieweit sich diese Techniken als spezifisch weiblich profilieren lassen, sollten sie nach Weigel „zu einer die logo- und phallozentrische Ordnung unterlaufenden (subversiven) Energie ${ }^{\text {‘436 }}$ werden.

Versucht man die theoretische Komplexität und Raffinesse der Konzepte der weiblichen Ästhetik auf ihre Applizierbarkeit auf literarische Texte zu überprüfen, so wird man m. E. feststellen müssen, dass die zur (höchstens) einer Bewegung oder einer Energie degradierte Weiblichkeit eher durch simple Eingriffe in die textuelle Oberfläche erreichbar ist. In der literarischen Praxis kann nämlich das Procedere, das auf die Hervorbringung des spezifisch Weiblichen abzielt, nur mit wenigen Mitteln durchgeführt werden. Dem Spiel mit der gegebenen Sprache, will es die Lesbarkeit nicht komplett abschaffen, stehen nicht viele Regelabweichungsmanöver zur Verfügung. Das Gefühl der Beschränktheit im Ringen ums Hervorbringen des originell Weiblichen beschreibt deutlich die Schriftstellerin Verena Stefan:

„Beim schreiben [...] bin ich wort um wort und begriff um begriff an der vorhandenen sprache angeeckt. [...] Die sprache versagt, sobald ich über neue erfahrungen berichten will. angeblich

\footnotetext{
${ }^{432}$ Nicole Masanek, Männliches und weibliches Schreiben? Zur Konstruktion und Subversion in der Literatur, Würzburg 2005, S. 20.

${ }^{433}$ Ebd.

${ }^{434}$ Ebd., S. $20 \mathrm{f}$.

${ }^{435}$ Ebd., S. 21.

${ }^{436}$ Ebd.
} 
neue erfahrungen, die im geläufigen jargon wiedergegeben werden, können nicht wirklich neu sein. ${ }^{6437}$

Im Bewusstsein ihres Beschränktseins sucht Stefan Strategien eines unterlaufenden Schreibens zu entfalten:

„Ich zerstöre vertraute zusammenhänge. ich stelle begriffe, mit denen nichts mehr geklärt werden kann in frage oder sortiere sie aus. - beziehung, beziehungsschwierigkeiten, mechanismen, sozialisation, orgasmus, lust, leidenschaft - bedeutungslos. sie müssen durch neue beschreibung ersetzt werden, wenn ein neues denken eingeleitet werden soll. jedes wort muss gedreht und gewendet werden, bevor es benutzt werden kann - oder weggelegt wird. “438

Diese simplen Eingriffe der Verfremdung und des Konstruierens von Neologismen scheinen das Waffenarsenal der weiblichen Ästhetik fast zu erschöpfen. Das bloße Herumbasteln mit den Bausteinen der vorhandenen Sprache lässt der schriftstellerischen Kreativität nicht besonders viel Freiheit und die Kreierung einer hyper-subversiven Bewegung, (bei gleichzeitigem Aufrechterhalten der Lesbarkeit des Textes) die aus geschickter Handhabung der Elemente der Sprache hervorgebracht wird, scheint eine nahezu geniale Schreibkunst vorauszusetzen. $\mathrm{Ob}$ Jelinek jene bereits beherrscht hat, diese Frage bleibt eher den literarischen Geschmäckern überlassen. In dem Versuch, der Lust, dem Sexuellen, den weiblichen Blick zu verleihen, sieht sie sich jedoch als gescheitert. Es bleibt daher zu fragen, was dieser Versuch hervorzubringen vermochte?

$\mathrm{Zu}$ den am meisten irritierenden Momenten in diesem Buch gehört m. E. das strategisch desorientierende Spiel mit der Lust. Um welche Art Lust handelt es sich aber? Ina Hartwig macht - den pornographischen Inhalt in Lust reflektierend - darauf aufmerksam, dass Jelineks sexuelle Poetik „eines der entscheidenden pornographischen Sujets nicht übernimmt: nämlich die Lust der Frau. “439 Ist es dann möglich, dass Hartwig einen der für Gerti bedeutendsten Momente im Roman übersieht, nämlich den Effekt der Affäre mit Michael? Dieser wird doch als deutlicher Gewinn dargestellt: ,[...] in der Frau, die das Höchste erleben und erledigen wollte, sind kernlose Werke in Kraft getreten worden. Ein Quellengebiet ist erschlossen, von dem sie jahrzehntelang heimlich träumte. [...] Ein Flächenbrand. (L, 116) [...] die Lust hat Gerti aus sich herausgerissen [...] (118)“ Es muss den Leser erstaunen und verwirren zugleich, dass sich Gertis Lust in Verbindung mit Michaels Lust entfachen und entfalten

\footnotetext{
${ }^{437}$ Verena Stefan, Häutungen: autobiografische Aufzeichnungen, Gedichte, Träume, Analysen, München 1975, S. $3 f$.

$438 \mathrm{Ebd}$.

${ }^{439}$ Ina Hartwig, Sexuelle Poetik. Proust Musil Genet Jelinek, Frankfurt am Main 1998, S. 247.
} 
vermochte, mit einer Lust also, die auf die gleiche Art und Weise Gertis Ehemann in sich zu entfachen wusste: „,...] und eure Lust bleibt immer dieselbe! Sie ist eine endlose Kette von Wiederholungen, die uns mit jedem Mal weniger gefallen, weil wir durch die elektronischen Medien und Melodien daran gewöhnt wurden jeden Tag etwas Neues ins Haus geliefert zu kriegen.“ (L,123) Diese angeblich falsche, nach einer männlichen Libido-Ökonomie vorprogrammierte $^{440}$ Lust lässt, wie es sich hier zeigt, beide Geschlechter am Genießen teilhaben: „Solche Gewalten werden vom immergleichen Gaul, der den Körper des Mannes zieht und von anziehenden Frauen vorangepeitscht wird, ausgesandt und erfassen rasch die zwergenhaftesten Zweige des weiblichen Wesens.“ (L, 116) Hat aber somit Jelinek nicht gerade die mysteriöse Lust inklusive das rätselhafte Genießen in ihrer Banalität enttarnt? Anscheinend nicht, denn: „Jetzt sprechen allein die Sinne, doch wir verstehen sie nicht, denn sie haben sich unter unserer Sitzfläche in etwas Unbegreifliches verwandelt.“ (L, 114) Einmal wieder pflegt die Lust-Autorin ihre Leser daran zu erinnern, dass es Erfahrungen gibt, die sich der Sprache entziehen, die jedoch an Orten aufzukeimen suchen, deren Erreichen uns mit dieser außersprachlichen (außersymbolischen) Einsicht bescheren mag. Ähnlich wie Kristeva mit ihrem Konzept des Geno- und Phänotextes, scheinen Jelineks literarische Lust-Spiele das Trieb-Sinn-Verhältnis ${ }^{441}$ literarästhetisch zu illustrieren. Die Sinnhaftigkeit des Romans Lust könnte sich daher nur dann offenbaren, „wenn zur gleichen Zeit der Zeichenträger, d.h. die Sprache in ihrer sinnlich konkreten Gestalt wahrgenommen wird.“442 Das Phänomen Lust kann somit nur sehr beschränkt theoretisch erfasst und expliziert werden.

Die Lust-Idee könnte aber noch weitere ehrgeizigere Ziele erreichen, indem sie als ein Begriff-Dietrich fungieren würde, mit Hilfe dessen in den herrschenden Diskurs eingebrochen werden könnte, um seine Funktionierungsweise zu karikieren und zu unterlaufen. Der Angriff fokussiert vor allem das Sexuelle, das Geschlechtliche überhaupt, die Allgegenwärtigkeit der Lust subvertiert und verzerrt dabei auch das genuin Außersexuelle, d.h. all dies, womit die unzähligen Sexszenen unterbrochen werden. Die folgende Passage schildert den Anfang einer Szene, in der der Leser zum ersten Mal mit der Art und Weise, wie sich das Geschlechtsleben des Ehepaars in Lust abspielt, konfrontiert wird:

„Neben der Frau fallen Kleidungshaufen zusammen wie tote Tiere. Der Mann, immer noch im Mantel, steht mit seinem starken Glied zwischen den Falten seiner Kleidung, als fiele Licht auf einen Stein. Strumpfhose und Unterhose bilden einen feuchten Ring um die Hausschuhe der

\footnotetext{
${ }^{440}$ Vgl. Luce Irigaray, Genealogie der Geschlechter, Freiburg 1989, S. 45.

${ }^{441}$ Vgl. Johanna Bossinade, a. a. O., S. 48.

${ }^{442}$ Ebd. „Dieser Appell an die doppelte, sowohl sinnhaft als auch sinnlich orientierte Wahrnehmung der Subjekte ist zugleich das, was die Literatur vom allgemeineren Sprachgebrauch unterscheiden soll.“
} 
Frau, aus denen sie steigt. Das Glück scheint die Frau schlaff zu machen [Hervorhebung - K.S.] sie kann es nicht fassen. Der schwere Schädel des Direktors wühlt sich beißend in ihr Schamhaar, allzeit bereit ist sein Verlangen, etwas von ihr zu verlangen.“(L, 17)

Diese Textpassage verrät zunächst überhaupt nicht, dass die beiden Eheleute eine Kluft trennt, was die Lust auf Sex miteinander betrifft. Die vorangegangenen Textpassagen informieren zwar ausdrücklich über die besonders ausgeprägte Lust des Ehemannes darauf, mit seiner Frau sexuell zu verkehren, die Einstellung Gertis scheint jedoch - was der von mir hervorgehobene Satz bezeugt - der des Mannes zu ähneln. Diese Irreführung wird jedoch schnell enttarnt. Noch im Laufe dieser ersten Sexszene, von der mit unzähligen Unterbrechungen abgeschweift wird, wird eine ganz andere Lage der Ehefrau Hermanns dargestellt. ${ }^{443}$

Wie unter dem Mikroskop bildet Lust Mechanismen der männlichen Lust ab, jede Körperhaltung der männlichen Figuren zielt gerade auf Lust ab oder wird sehr bald ihre volle Aufmerksamkeit der Lust widmen. Hermann und Michael scheinen fast ausschließlich damit beschäftigt zu sein, was Lust entfalten und befriedigen kann. Anders Gerti, die sich ihre Lust nicht einmal vorstellen kann und sich von dem falschen Genießen, das nur eine mit einem sehr kurzen Haltbarkeitsdatum etikettierte Lust produzierte, täuschen lässt.

Was Jelinek zu kreieren vermochte, ist eine gigantische rhetorische Maschinerie, die - um sich der sexuell gefärbten Metaphorik zu bedienen - eine literarische Inszenierung eines coitus interruptus darstellt. Keine Sexszene im Text wird nämlich ohne Unterbrechungen dargestellt, mehrere Abschweifungen lockern die negative Anspannung kaum, man ahnt schnell - gleich wird man wieder in den krassen Kampf der Geschlechter hineingeworfen, in dem noch heftiger und noch obszöner mit Gerti umgegangen wird. Die eingeflochtenen Vergleiche verfremden den sexuellen Kontext, die Wortspielereien scheinen der vergewaltigungsähnlichen Szenen ihren Ernst zu nehmen. Die unbegreifliche (Para)Logik der Lust schafft eine (diskursive) Kluft zwischen denen, die befriedigt werden können, und denen permanent Unbefriedigten. Die erste Gruppe bilden im Roman die beiden Herren, deren Kenntnis der Dialektik der Lust und deren geschickter/kompetenter Umgang mit ihr, sie konsequent an der Seite der Befriedigten positionieren lässt. In der Gruppe der Verlierer finden sich, wie erwartet, Gerti, aber auch der Leser. Gertis Verlust resultiert - um es auf den Punkt zu bringen - aus der Unmöglichkeit, die Position des Subjekts zu besetzen. ${ }^{444}$ Die Nicht-Befriedigung der Erwartungen des Lesers resultiert dagegen aus seiner Desorientierung,

\footnotetext{
${ }^{443}$ Siehe Lust, S. 19.

${ }^{444}$ Vgl. Fn. 407, S. $112 f$.
} 
zu der ihn die Lust-Lektüre führen musste. ${ }^{445}$ Das Fiasko der Bedeutungsbildung und des Erkennens der kommunikativen Intention des Textes sind als die logischen Konsequenzen des Scheiterns der Jelinekschen Absicht, ,Peripherie des Symbolischen zu kolonisieren', und auf dem neu gewonnenen Terrain das spezifisch Weibliche aufkeimen zu lassen, zu deuten. Der Text verrät seine Strategien schrittweise, so, wie sich Jelinek Schritt für Schritt dessen bewusst wird, dass sie ein unmögliches Unterfangen zu bewerkstelligen sucht. Der Roman ist somit mit Unmengen kleinkalibrig irritierenden Momenten gespickt, in denen nicht gleich das Desorientierungspotential bösartig lauern muss. Nach mehr als der Hälfte des Umfangs des Romans liest der Rezipient folgende Frage an sich gestellt, die keines Kommentars bedarf: „Haben Sie noch immer Lust zu lesen und zu leben? Nein? Na also.“ (L, 170) Ähnlich verblüffend muss auch das Geständnis eines Sich-Versprechens des Erzählers wirken: „Und noch etwas, das die Natur versprochen hat: das Arbeitsrecht, nach dem jeglicher Bewohner, der ein Bündnis mit seinem Unternehmer geschlossen hat, auch von Gott wieder durch den Tod erlöst werden kann (die stinkende Losung Gottes). Jetzt hab ich mich versprochen.“ (L, 239) Die kleinen Irritationen wissen sich jedoch zu häufen und solange man versucht, mit aller Anstrengung des Gedächtnisses plausible Verknüpfungen zwischen ihnen zu erstellen, subvertieren sie konsequent den Prozess der Sinnbildung. Entscheidet man sich aber irgendwann dafür, jegliche Abschweifungen, Kommentare, Apostrophierungen (als potentiell sinnhaftigkeitsbringende) zu ignorieren, dann bleibt nur noch Sex, dessen krass seltsame Darstellungsweise nach einer zu enthüllenden Logik der Lust suchen lässt.

Möchte man daher die Lage des Lust-Rezipienten einleuchtend skizzieren, so würde ich sie mit einer Falle assoziieren. Der Text verspricht Porno, subvertiert jedoch seinen Effekt; der Roman ist politisch, liefert jedoch kein fixierbares Programm; Lust möchte die Sprache selbst sprechen lassen, aber die Worte reichen dafür nicht aus. Einen zerfetzten, löchrigen Text möchte man zum Sinnhaften flicken, wie Puzzles verbinden, seine verwirrende Logik verstehen.

Die von mir als neuartig subversiv, d.i. als hypersubversiv charakterisierte literarästhetische Gestaltung des Romans Lust resultiert im Grunde aus einer extremen Ambivalenz, die in ihrer Intensität schrittweise zur Indifferenz ${ }^{446}$ mutiert. Es gibt mehrere Wege, dieses durchaus postmodernes Charakteristikum zu erreichen, in Lust ist es m.E. die extreme Affirmation der Oberfläche. Weit radikaler als noch in Pynchons CL 49 führt Jelinek

\footnotetext{
${ }^{445}$ Die Metapher eines coitus interruptus ließe sich darüber hinaus doppeldeutig und/oder doppelschichtig verstehen. Erstens wird die in Gang gesetzte Lustentfaltung Gertis vorzeitig unterbrochen, zweitens wird die Lust am Text, also die Lust, dem Gelesenen eine Bedeutung zu entnehmen, konsequent unterbrochen.

${ }^{446}$ Gedacht als Austauschbarkeit, vgl. Peter Zima, a.a.O., S. 344.
} 
„eine drastische Aufwertung der Signifikanten und der gesamten Ausdrucksebene“4477 durch, nach der der Leser in diesem Roman nichts Geheimnisvolles mehr findet. Die Radikalisierung der Affirmation der Textoberfläche inszeniert die Lust-Autorin durch eine permanente Vertreibung des Psychologischen aber auch durch den Verzicht auf die Vorgeschichte der Protagonisten. ${ }^{448}$ Eine durch den Assoziationswahnsinn erzeugte Fragmentierung des Romantextes scheint m.E. die Affirmation der Oberfläche an einen Punkt gebracht zu haben, an dem sie den Leser nur noch ,an die Konstruktion neuer ,sekundärer (und das heißt: ambiger) Verstehensraster“ ${ }^{449}$ denken lässt. Eine präzise, einleuchtende Einsicht in die ,Logik‘ der Ambivalenz in ihrer postmodernen Radikalisierung kann m.E. das Erreichen eines neuen Verstehensrasters maßgeblich erleichtern. Im Falle des Lust-Romans würde ich die Quelle der „Ambivalenz als dialektische[r] Einheit der Gegensätze ohne Synthese, als Zusammenführung unvereinbarer Werte [..] und als Zusammenwirken einander entgegengesetzter Regungen“ ${ }^{\star 450}$ in der verwirrenden Dialektik von Lust und Un-Lust, die dem Roman zugrunde liegt, situieren. Aus der Ambivalenz geht die Indifferenz hervor, „wenn die Zusammenführung der Gegensätze zu einer Dauererscheinung wird.““451 Dies lässt sich m.E. in Lust gut beobachten und zwar anders als in $C L 49$, wo die Intensität der Affirmation der Oberfläche und somit der Ambivalenz eine weit niedrigere Dynamik erreicht.

Lust ist ein Text auf der Suche, er möchte die Schnittstelle zwischen dem Weiblichen und dem Männlichen (er)finden und diesem ,anwesenden Abwesendsein“ einen ästhetischen Ausdruck geben. Die ersten Funde wurden bereits lokalisiert, der Ausdruck bleibt noch aus, da das bereits Ausgegrabene Qualitäten besitzt, die sich in Worte kaum kleiden lassen. Nur schielend vermag das Bewusstseinsauge des Lesers den doppelten Ort, das Semiotische, eine Art excluded middle des herrschenden Diskurses zu fassen.

„Aber nun rastet eine Weile.“ (L, 255)

\footnotetext{
${ }^{447}$ Ebd., S. 286.

${ }^{448}$ Siehe S. 98.

${ }^{449}$ Christoph Bode, Ästhetik der Ambiguität : zu Funktion und Bedeutung von Mehrdeutigkeit in der Literatur der Moderne, Niemeyer Tübingen 1988, S. 290.

${ }^{450}$ Peter Zima, a.a.O., S. 303.

${ }^{451}$ Ebd., S. 344.
} 


\section{Unheimliche* Desorientierung in Witold Gombrowicz' Kosmos}

\subsection{Von Indizien zu Kosmos}

Witold Gombrowicz in die Reihe der postmodernen Schriftsteller zu stellen ist, zumindest in Polen, ziemlich umstritten. ${ }^{452}$ Im Kontext der kurz angeführten Zuordnungen, die Gombrowicz entweder in der Moderne oder in der Postmoderne situieren, habe ich mich, wie bereits erwähnt, dafür entschieden den Roman Kosmos als einen Übergangsroman einzustufen. Kosmos (beendet 1965) war Gombrowicz‘ letzter Roman und der einzige, für den er 1967 den Preis Prix Formentor erhalten hat. In Polen konnte der Roman erst 1987 erscheinen, die erste Ausgabe in der deutschen Sprache erschien bereits im Jahre 1966 und trug den Titel Indizien. Da man in der ersten Übersetzung auf zahlreiche Unzulänglichkeiten ${ }^{453}$ hingewiesen hatte, wurden Gombrowicz' Werke erneut übersetzt. Beim Kosmos entschied man sich diesmal dafür, den Originaltitel beizubehalten, die neue Ausgabe erschien 1985. Die Übernahme des Originaltitels schien auch dem Inhalt des Romans besser $\mathrm{zu}$ entsprechen, der Titel Indizien legte „das Werk doch zu sehr auf die darin enthaltene

\footnotetext{
* Ich habe mich für die nähere Bestimmung der Desorientierung in Kosmos für das Adjektiv ,unheimlich` entschieden, weil eine Verdichtung von Unheimlichkeiten für die Konstituierung der Desorientierung maßgeblich mitverantwortlich ist. ,Unheimlich' meint hier zugleich (in seinem umgangssprachlichen Gebrauch) etwas Besonderes, Ungewöhnliches und nicht Banales.

${ }^{452}$ Zahlreichen, nicht wenig überzeugenden Argumenten, die Gombrowicz als Postmodernisten erklären, werden nicht weniger überzeugende Argumente gegenüber gestellt, die darauf bestehen, diesen Autor der literarischen Moderne zuzuordnen. Zu den prominentesten Anhängern der ersten Position zählt Zdzisław Łapiński, zu ihren vehementesten Kritikern dagegen Włodzimierz Bolecki, dessen Buch Polowanie na postmodernistów [Die Jagd auf Postmodernisten] sich als eine der wichtigsten und interessantesten Stimmen in der Diskussion über die Vorläufer der Postmoderne in Polen erwies. Bolecki wirft den Literaturwissenschaftlern, die Werke Gombrowicz', aber auch Stanisław Ignacy Witkiewiczs und Bruno Schulz', als postmodern interpretieren vor, ihre Zuordnungen beruhen auf wenig plausiblen methodologischen Eingriffen, die er als Postmodernisierung dieser Autoren bezeichnet. Vor allen Dingen ist es aber die Konzipierung des Subjekts, die diese Schriftsteller nach Bolecki auf keinen Fall der Postmoderne zuschreiben lässt. Eine detaillierte Konfrontation beider Positionen würde natürlich den Rahmen dieser Arbeit sprengen, ich würde aber Bolecki gern einen Kompromiss vorschlagen, in dem ich nicht alle Werke Gombrowicz', aber sicherlich Kosmos als - wenn auch nicht durchaus postmodern, dann wenigstens - sichtbar postmodern verfeinert sehen werde.

${ }^{453}$ Alle vier Romane Gombrowicz' erschienen in Deutschland zwischen 1960 und 1966 und wurden von Walter Tiel übersetzt. Der Herausgeber war der Neske-Verlag. Seit 1983 wurden alle Werke Gombrowicz' nach der erneuten, bzw. korrigierten Übersetzung von Carl Hanser-Verlag herausgegeben. Der 1985 erschienene Kosmos wurde von Olaf Kühl übersetzt. Näheres dazu und auch die ersten Reaktionen der deutschsprachigen Presse $s$. Zbigniew Wilkiewicz, Eine Entdeckung. Die Prosa Witold Gombrowicz' in der deutschsprachigen Presse, in: Heinz Kneip, Hubert Orłowski (Hg.), Die Rezeption der polnischen Literatur im Deutschsprachigen Raum und die der Deutschsprachigen in Polen 1945-1985, Darmstadt 1988.
} 
detektivische Intrige fest, wodurch ihm sein totaler - eben ,kosmischer ${ }^{6}$ - Anspruch genommen wurde. “454

Die Popularität Gombrowicz‘ in Polen ließ einen enormen Zuwachs an Forschungsliteratur entstehen, die zu einer regelrechten Gombrowiczologie angewachsen ist. Betonen möchte ich hier zwei Tendenzen: eine, die die Forschung zu diesem Autor seit Jahrzehnten bestimmt, und eine andere, die in den letzten Jahren in der Gombrowiczologie allmählich an Bedeutung gewann. 1976 bemerkte Janusz Sławiński, dass Gombrowicz zu einem sehr seltenen Beispiel eines Autors wurde, der die gesamte Forschung zu seinen eigenen Werken fast ausnahmslos beeinflusste und sich somit als der Hauptgombrowiczologe profilierte. ${ }^{455}$ Diese Tendenz besitzt die von Sławiński klar diagnostizierte Schwäche innerhalb der Gombrowiczologie: „Ihre Sprache ist fast restlos die Sprache Gombrowicz“." 456 Diese sehr treffende und einleuchtende Reflexion Sławińskis wurde von ihm im Sinne eines ermunternden Aufrufs konzipiert - die Literaturwissenschaft solle endlich den Versuch wagen, andere Gesichtspunkte (als nur die des kommentierenden Autors) zu bestimmen, sich außerhalb des Forschungsobjektes $\mathrm{zu}$ positionieren und vor allem aufzuhören, Gombrowicz mit Gombrowicz zu interpretieren. ${ }^{457}$

Die zweite Tendenz in der literaturwissenschaftlichen Forschung zu Gombrowicz, die sich besonders im letzten Jahrzehnt bemerkbar machte, sondiert den Wert, der den einzelnen Werken des Schriftstellers zugeschrieben wird. Wie der Jubiläumsband zum 100. Geburtstag Gombrowicz $^{458}$ deutlich zeigt, avancierte sein einst wenig geschätzter und seltener interpretierter Roman Kosmos zu einem besonders intensiv untersuchten Werk, in dem konsequent neue ästhetische und philosophische Qualitäten sowie bis dahin nicht decodierte Botschaften entdeckt wurden. Einige Interpreten haben zu Recht, wie ich meine, darauf verzichtet, Kosmos mit früheren Romanen Gombrowicz‘ in Verbindung zu setzen, und haben sich statt nach Gemeinsamkeiten zu suchen, ausschließlich auf die Ergründung der Tiefen und Verwirrtheiten des Kosmos-Textes konzentriert. Auch zu diesem Roman hat der Autor zahlreiche Kommentare und interpretatorische Hinweise hinterlassen, die von fast allen

\footnotetext{
${ }^{454}$ Zbigniew Wilkiewicz, a.a.O., S. 168-9. Die Richtigkeit der Übernahme des Originaltitels betonte auch Fritz J. Raddatz: „Der deutsche Titel Indizien reduziert diese Pinzettenprosa auf den Kriminalablauf einer abermals mörderisch-rauschhaften Fabel, während doch der Originaltitel Kosmos nahezu trotzig bekennerhaft klingt, mehr sagen will, alles sagt." Fritz J. Raddatz, Verwerfungen. Sechs literarische Essays., Frankfurt am Main, 1972, S. 154.

${ }^{455}$ Vgl. Janusz Sławiński, Teksty i teksty [Texte und Texte], Warszawa 1990, S. 164.

${ }^{456}$ Ebd., S. 165. [„Jej język jest prawie bez reszty językiem Gombrowicza."]

${ }^{457}$ Vgl. ebd., S. 165.

${ }^{458}$ Es handelt sich um das unter der Redaktion von Jerzy Jarzębski erschienene Buch Witold Gombrowicz. Nasz współczesny. [Witold Gombrowicz. Unser Zeitgenosse], Kraków 2010.
} 
Interpreten gern angeführt und für bare Münze genommen wurden. Kaum jemand zeigte sich misstrauisch genug, um Gombrowicz‘ Kosmos-Kommentare auf ihre Richtigkeit detailliert und präzise zu untersuchen. Angesichts dieser Tatsache scheinen die Ausnahmen an Bedeutung zu gewinnen und die gegen den Strich Interpretierenden sollen ihre interpretatorische Fruchtbarkeit leicht beweisen. Es wäre jedoch unfair, das Misstrauen gegenüber dem kommentierenden Gombrowicz in ein Ignorieren aller seiner Kommentare umzuwandeln. Die Kosmos-Kommentare werden daher zunächst zur Kenntnis genommen und im Laufe der Lektüre mit dem Romangeschehen konfrontiert.

„Kosmos ist für mich schwarz, vor allen Dingen schwarz, etwas wie ein schwarzer, zerwühlter Strom voller Wirbel, Hemmnisse, überschwemmter Gebiete, ein schwarzes Gewässer, das Tausende von Abfällen dahinträgt, und ein darin vergaffter Mensch - vergafft in dies Gewässer und von ihm davongetragen - der versucht, zu entziffern, zu verstehen, zu irgendeinem Ganzen zu verbinden ... Schwärze, Grausen und Nacht. Eine von gewaltiger Leidenschaft, von verdammter Liebe durchdrungene Nacht.“459

„Dieser Roman handelt vom Entstehen dieser Geschichte selber, vom Entstehen der Wirklichkeit, von dem, wie sie ungeschickt, lahm, aus unseren Assoziationen geboren wird... wie denn sollte eine solche Formung kein Knirschen, keine Widerstände, keine Fälschungen hervorrufen, alle Augenblicke verfällt die ungelenke Konstruktion in ein Chaos. Kosmos ist ein Roman, der sich selber während des Schreibens erschafft.“460

Beide oben zitierte Textausschnitte sollen eine einführende Funktion erfüllen und signalisieren dabei das allgemeine Klima des Romans (im Falle der ersten Passage) und mögliche Schwierigkeiten, die der Absicht des Autors entsprachen, eine Geschichte zu schreiben, die sich während des Lesens selbst zu konstituieren scheint (in der zweiten Passage). Es hat keinen Sinn, die in der ersten Passage geäußerte Meinung auf ihre Richtigkeit zu überprüfen, da sie nur die Wahrnehmung des Autors präsentiert. Die zweite Passsage formuliert dagegen eine zusammenfassende Interpretation von Kosmos, deren Bestätigung oder Verneinung zu den Aufgaben des Interpreten des Romans gehört. ${ }^{461} \mathrm{Zu}$

\footnotetext{
${ }^{459}$ Witold Gombrowicz, Eine Art Testament, München Wien, 1996, S. $128 \mathrm{f}$.

${ }^{460}$ Ebd., S. $132 f$.

461 Józef Olejniczak und Michał Paweł Markowski sind nach meinem Wissen die einzigen Interpreten Kosmos', die diese Interpretation des Romans als irreführend erklärt haben. Olejniczak schreibt: „Gombrowicz führt in seinen Autointerpretationen auf Irrwege! Gombrowicz will, dass man ihn [Kosmos - K.S.] als eine Erzählung über das Erschaffen der Erzählung liest, den Rezipienten zieht er sogar zur Mitverantwortung für dieses Entstehen. Und das grundsätzliche Problem liegt woanders. In der Tat ist es keine Erzählung über das Erzählen, sondern über das Benennen der Welt, über die Grenzen der Mimesis." [„Gombrowicz w swoich autointerpretacjach wiedzie na manowce! [...] Gombrowicz chce, by czytać go [Kosmos - K.S.]) jako opowieść o stwarzaniu się opowieści, odbiorcę nawet [...] czyni współodpowiedzialnym za jej powstawanie. A problem
} 
seinem letzten Roman hat Gombrowicz aber auch Kommentare zu konkreten Szenen hinterlassen. Sie werden im Laufe dieses Kapitels zitiert und mit Untersuchungen der literaturwissenschaftlichen Forschung konfrontiert. Es zeigt sich dabei, dass obwohl er auf die besondere Logik in seinem Roman Kosmos hingewiesen hat und klare Hilfe zum Entziffern der gesamten Bedeutung des Romans lieferte, die Interpreten immer neue, zum Teil überraschende Sinnschichten entdecken, sei es auf Irrwegen, zu denen sie der Autor selbst geführt hat, oder durch Erkundungsgänge in Regionen des Textes, die bisher unerforscht blieben. Kosmos scheint das frappierendste Werk Gombrowicz ${ }^{6}$ zu sein, wobei die Liste der frappierenden Momente konsequent, mit fast jeder ordentlichen Interpretation des Romans erweitert wird. Es sind vor allem Versuche des literarischen Ergründens des Grenzbereichs „zwischen dem unabsetzbaren, undarstellbaren Fluten und dem Beharren auf der symbolischen Darstellung, die den kulturellen Konventionen unterworfen bleibt.“ ${ }^{462}$ Markowski ist es meines Erachtens am besten gelungen, die sich in Gombrowicz' Werken entfaltende Dialektik des Unsagbaren und des Darstellbaren zu erkennen und sie treffend bildhaft zu beschreiben:

„Zwischen dem, was sich nicht beschreiben lässt (und was Kristeva als Le semiotique und Lacan als Le Reel bezeichnet) und dem, was der Beschreibung unterliegt (Le symbolique), zwischen dem ungezähmten Gestammel und dem es zäumenden Logos, [zwischen - K.S.] dem sinnlichen Rhythmus und dem gesellschaftlichen Gesetz [...] lugt in den Spalten im Text das, was dem Text entwischt. ${ }^{463}$

Gombrowicz' Literatur, geknüpft aus unzähligen Versuchen von der ,Unwirklichkeit zu der Wirklichkeit durchdringen` zu wollen, konstituiert eine neue Sprache, die es ermöglichen soll, „etwas über diese arrogant ausgebreitete ,Fläche des Unbestimmten“, die die Welt ist, zu sagen. “" ${ }^{664}$

zasadniczy jest gdzie indziej. Rzecz w tym, że to powieść nie o opowiadaniu, a o nazywaniu świata, o granicach mimesis."] Józef Olejniczak, W kosmosie 'Kosmosu'. Opowiem (wam) przygodę... Witold Gombrowicz [Über den Kosmos des 'Kosmos". Ich erzähle (euch) ein Abenteuer... Witold Gombrowicz] In: Jerzy Jarzębski (Red.) Witold Gombrowicz. Nasz wspótczesny. [Witold Gombrowicz. Unser Zeitgenosse], Kraków 2010, S. 376f. Markowskis Behauptungen zu Kosmos werden in weiteren Untersuchungen erwähnt.

${ }^{462}$ Michał Paweł Markowski, Czarny nurt Gombrowicz, świat, literatura. [Die schwarze Strömung Gombrowicz, Welt, Literatur] Kraków 2004, S. 10. [„,między nieusuwalnym, nieprzedstawialnym odmętem, a równie upartym przedstawieniem symbolicznym, podporządkowanym kulturowym konwencjom."]

${ }^{463}$ Ebd., S. $10 \mathrm{ff}$.[„Między tym, czego opisać się nie da (i co Kristeva nazywa Le semiotique, Lacan zaś Le Reel), a tym, co opisowi podlega (Le symbolique), między nieokiełznanym bełkotem a kiełznającym je logosem, cielesnym rytmem a społecznym prawem...przez szpary w tekście przeziera to, co wymyka się tekstowi."]

${ }^{464}$ Ebd., S. 14. [„,którym można by coś powiedzieć o tej arogancko rozpostartej 'połaci nieokreślonego', jaką jest świat."] 
Das Aufspüren des Aufblitzens des Unsagbaren zwischen den Zeilen des Kosmos-Textes gehört zu den größten Herausforderungen seiner Lektüre. Es wird dabei vermutet, der Text könne nicht alles sagen, was er ausdrücken wolle; es wird behauptet, man versuche uns dazu zu bringen (verleiten), die Grenzen des Textuellen, des Diskursiven zu sondieren. Die einzige Frage, die am Ende bleibt, ist: Was kann ich wissen? Über die Wirklichkeit, über den Kosmos, über das Bewusstsein. Ist die Grenze zwischen dem Wissen und dem Nicht-Wissen, dem Begreifen und dem Nicht-Begreifen fließend oder lässt sich eine klare Linie eines Jenseits des Verstehens markieren? In Kosmos betrachtet ein „ein a-menschlicher Beobachter [...] durch meterdicke Bleiglasscheiben, strahlensicher geschützt vor jeglicher Teilnahme, Figurationen.“" 465 Trotzdem erwies sich der Schutz als nicht stark genug, die Anomalien wussten die sensibelsten Öffnungen des Bewusstseins anzugreifen, die Apperzeption zu fesseln und diese ins Gefängnis der privaten Logik zu bringen. Schrittweise werden dem Kosmos-Leser Devianzen appliziert, die sein lebensweltliches Wissen sowie seine Resistenzfähigkeit gegen Momente des Sinnentzugs herausfordern werden. Durch ein geschicktes Dosieren der Irritationen und der Unklarheiten durch den Erzähler wird der Leser allmählich der Orientierungspunkte beraubt, bis er endlich den roten Faden der Erzählung nicht mehr bestimmen kann und seiner Desorientierung bewusst wird. Dem Rekonstruieren dieses Prozesses ist das folgende Kapitel gewidmet.

In seinem ganzen Werk wusste Gombrowicz auf eine ausgesprochen geschickte Art und Weise die Manifestierung seiner literarischen Phantasie mit einem konsequenten Vortrag seiner Weltanschauung zu verbinden. ${ }^{466}$ In diesem durchdachten Oszillieren fand der Autor von Kosmos den genialsten Weg, seiner großen Obsession - der Form - einen möglichst komplexen und raffinierten Ausdruck $\mathrm{zu}$ geben. Grob genommen lässt sich die Gombrowiczsche Form unter zwei Aspekten untersuchen: als die zwischenmenschliche Deformierung und als ,uns eingeborene Notwendigkeit, >die Gestalt abzurunden «“467, die als $>$ Imperativ der Form< bezeichnet wurde. Fand die schmerzhafte Deformierung ihren

\footnotetext{
${ }^{465}$ Fritz J. Raddatz, Verwerfungen. Sechs literarische Essays., Frankfurt am Main, 1972, S. 154.

${ }^{466}$ Vgl. Jerzy Jarzębski, Pojęcie ,formy' u Gombrowicza [Der Begriff der ,Form' bei Gombrowicz], in: Zdzisław Łapiński (Hg.), Gombrowicz i krytycy [Gombrowicz und Kritiker], Kraków Wrocław 1984, S. 313. Jarzębski lieferte mit diesem Aufsatz die erste ausführliche Untersuchung zum Begriff der Form bei Gombrowicz.

${ }^{467}$ Witold Gombrowicz, Eine Art Testament, a.a.O., S. 51. Gombrowicz betonte, dass bei ihm „die Form stets die Parodie einer Form ist“, Ebd., S. 134. Einen einleuchtenden Vergleich der Form und der Parodie führte Ryszard Nycz durch. Beide, betonte Nycz, sind deformierend und degradierend, der größte Unterschied zwischen ihnen besteht aber darauf, dass "die Form die unwillkürliche Parodie ist und die Parodie der Form ist ihre Selbstkenntnis" [(...) gdy forma jest parodią bezwiedną, to parodia formy jest jej samowiedzą."] Ryszard Nycz, Sylwy współczesne. Problem konstrukcji tekstu [Die zeitgenössischen Silven. Das Problem der Textkonstruktion], Wrocław, Warszawa, Kraków, Gdańsk, Łódź 1984, S. 70.
} 
ästhetischen Ausdruck in früheren Romanen Gombrowicz', so stellt Kosmos seine regelrechte Auseinandersetzung mit dem Imperativ der Form dar. Sein letzter Roman konnte somit als ein experimenteller Versuch gelten, die „Tiefenströmung von Form herauszustellen, [...] sie [...] für sich alleine in Erscheinung treten“468 $\mathrm{zu}$ lassen und das in dieser ,,zerquirlt[en], aufgewühlt[en], immer neue Möglichkeiten in sich bergend[en]“469 Strömung versunkene Bewusstsein auf seine Fähigkeit des Kreierens möglicher Wirklichkeiten zu untersuchen. Zum letzten Mal wurde „die Bestie der Form herausgefordert, nun muss man sie bei den Hörnern packen. ${ }^{\text {4470 }}$

\footnotetext{
${ }^{468}$ Ebd., S. 54

${ }^{469}$ Ebd.

${ }^{470}$ Ebd., S. 132.
} 


\subsection{Vom Spatz zu den Mündern oder die Welt mit Unheimlichkeit unternäht $t^{471}$}

Ähnlich wie im vorletzten Roman Gombrowicz‘ Pornografia trägt auch in Kosmos der Ich-Erzähler den Vornamen Witold. ${ }^{472}$ Den ersten Hinweis darauf, mit welcher Romangattung man es im Fall von Kosmos zu tun hat, findet der Leser nach zwei Seiten Lektüre. Deutlich suggeriert wird ein Detektivroman. Diese Spur, d.h. die Vermutung eines Detektivromans möchte ich in meiner ersten Annäherung an den Text aufnehmen. In den (von den Figuren) rezipierten ,Anomalien“ werden latente Desorientierungspotentiale vermutet, deren Freisetzung präzis lokalisiert und untersucht werden soll. Mit dem (anfänglichen) Schauplatz des Geschehens wird der Leser ziemlich chaotisch bekannt gemacht, indem man sein Wahrnehmungsvermögen mit wuchernden Aufzählungen überflutet:

„Schweiß, Fuks geht, ich hinter ihm, Hosenbeine, Absätze, Sand, wir schleppen und schleppen uns, Erde, Wagenfurchen, Schollen, Funkeln von glasigen Steinchen, Gleißen, Hitze, summt, flimmernde Glut, es ist schwarz von der Sonne, Häuschen, Zäune, Felder, Wälder, dieser Weg, dieser Marsch $[\ldots]^{“}(\mathrm{~K}, 7)$

Nach einigen Sätzen, in denen wir spärlich über die Gründe der Flucht des Erzählers nach Zakopane erfahren, fällt der Text wieder in den Rhythmus der Aufzählungen zurück. Viele bereits aufgezählte Elemente des Wegs, der Müdigkeit kommen wieder. Es lässt sich hier keine syntaktische Hierarchie feststellen, evoziert wird der Eindruck der Menge der Elemente, die an manchen Stellen bis zur Verwirrung führen kann. ${ }^{473}$ Nach einer kurzen Wanderung in der Sommerhitze entscheiden sich Witold und Fuks für eine Rast im Schatten des Gebüschs:

„Dort zwischen den Zweigen steckte etwas - etwas Absonderliches und Fremdes, wenn auch Undeutliches ragte dort...und dies betrachtete auch mein Kumpan. $\gg$ Ein Spatz. $\ll<>$ Aha. $<$ Es

\footnotetext{
${ }^{471}$ Das Adjektiv ,unternäht' ist die wörtliche Übersetzung des polnischen Adjektivs, podszyty', das aus dem ersten Roman Gombrowicz' Ferdydurke stammt. Das Wort entspricht generell dem deutschen ,unterfüttert' und wurde von Gombrowicz metaphorisch, im Sinne ,mit dem Kind unternäht' gebraucht. Da mir ,unternäht' weit subtiler erscheint als ,unterfüttert' und seine Bedeutung leicht erschließbar ist, habe ich mich für den Gebrauch dieses Neologismus' entschieden.

472 Nicht viele Informationen findet der Leser zur Person des Narrationsträgers, wir erfahren lediglich, dass er in Warschau studiert, Vater und Mutter, aus nicht näher erwähnten Gründen, satt hatte und zur Abwechslung nach Zakopane ins Tatra-Gebirge geflohen ist. In der Hauptstraße des Gebirgsstädtchens trifft Witold seinen alten Kumpel Fuks, der, auch von den Sorgen der Alläglichkeit fliehend, sich zur Erholung einige Tage in der Natur gönnen will. Da Fuks die Adresse einer billigen Pension weiß, die sich aber „weiter draußen, fast schon auf dem platten Lande" $(K, 7)$ befindet, machen sich die beiden sofort auf den Weg dahin.

${ }^{473}$ Vgl. dazu eine Analyse des Narrationsstils bei Kazimierz Bartoszyński, Kosmos i antynomie. [Kosmos und Antynomien] In: Zdzisław Łapiński (Hg.) Gombrowicz i krytycy [Gombrowicz und Kritiker] Kraków - Wrocław 1984 , S. 655-691.
} 
war ein Spatz. Der Spatz hing an einem Draht. Aufgehängt. Mit zur Seite geneigtem Köpfchen und aufgesperrtem Schnäbelchen. Er baumelte an einem Stück dünnen Drahtes, an einem Ast gehängt. Sonderbar. Ein gehängter Vogel. Ein gehängter Spatz. Diese Exzentrizität schrie hier mit lauter Stimme und deutet auf eine menschliche Hand, die sich ins Dickicht gedrängt hatte aber wie?" $(\mathrm{K}, 8)$

Der seltsame Fund ereignet sich jedoch nicht wirklich plötzlich, er wird durch die nächste Portion der Aufzählungen eingeleitet, als ob das tiefere Eindringen ins Gebüsch, mit allen dazu gehörenden Elementen, den Fund erst provozieren sollte:

„Er [Fuks - K.S.] drang etwas tiefer in die Sträucher ein, wo Nischen sich öffneten, Vertiefungen verdunkelt von oben verflochtenen Haseln und Fichtenästen, ich tauchte den Blick in das Gewirr von Blättern, Zweigen, Lichtflecken, Verdichtungen, gähnenden Löchern, Verklemmungen, Schrägen, Neigungen, Rundungen, weiß der Teufel, in einen fleckigen Raum, der angriff und zurückwich, anschwoll und weiß ich was, beiseite drängte, sich auftat ... verloren und schweißüberströmt fühlte ich schwarze und nackte Erde - von unten.“ (K, 8) 874

Der Fund im Gebüsch eröffnet sofort mehrere Erkenntnisperspektiven und sein Gewicht bestimmt die Richtung, in die sich das Abenteuer der Kameraden entfalten wird. Es mag ja auch nicht verwundern, denn ,in diesem üppigen Aufwuchern von Millionen Kombinationen“ $(\mathrm{K}, 8)$, das die Wahrnehmung des Erzählers ab jetzt völlig beherrscht, „, alles überhaupt kam plötzlich auf diesen Spatzen zugestürzt wie eine Menschenmenge auf den Knien, und er hatte den Thron bestiegen, der Exzentriker...und thronte in seinem Winkel.“ (K, 9) Beschlossen wird das Aufklären des Geheimnisses des hängenden Spatzen, zuerst muss aber endlich der Unterkunftsort erreicht werden. Die Tür der Pension, die Familie Wojtys gehörte, öffnet Katasia, die Verwandte der Hausbesitzerin, die sich als Wirtin der Pension zeigt. Dieser etwa vierzig jährigen molligen Frau hätten die frisch angekommenen Touristen kaum Aufmerksamkeit geschenkt, wenn nicht etwas Anomales in ihrem Gesicht von Witold entdeckt und sofort mit seltsamen Assoziationen verbunden worden wäre:

„Was mich bei dieser Frau stutzig machte, war eine sonderbare Verunstaltung des Mundes in diesem biederen Hausfrauengesicht mit hellen Äuglein - ihr Mund war an einer Seite wie angeschnitten, und diese Verlängerung, um eine Winzigkeit, um einen Millimeter, verursachte eine Verzerrung der Oberlippe, eine fortspringende oder ausgleitende, beinahe wie ein Kriechtier, - diese entschlüpfende Schlüpfrigkeit am Rande aber widerte mit schlangenhafter, froschartiger Kälte an und hatte mich dennoch auf der Stelle erwärmt und entbrannt, als der

\footnotetext{
${ }^{474}$ Der Spezifik, der in Kosmos mehrmals eingesetzten Aufzählungen von Elementen wird im zweiten Anlauf mehr Platz gewidmet. Hier sollte nur ihre erste Situierung signalisiert werden.
} 
dunkle Durchgang nämlich, der zur geschlechtlichen Sünde mit ihr führte, zur schlüpfrigen und schleimigen Sünde.“ $(K, 10)$

Die eingeschlichene (zweite) Anomalie konzentriert kurz die Aufmerksamkeit des Erzählers und bevor sie sich mit der früheren - der spatzartigen - zu verbinden vermochte, um das assoziative Aufwuchern aufs Neue anzukurbeln, wird sie zunächst in den Latenzzustand verdrängt. Die ersten Signale einer sich virusmäßig ausbreitenden Anomalie erscheinen während des Abendbrots in der Wahrnehmung Witolds, denn „die ausgleitende Lippe von Katasia fand sich in der Nähe von Lenas ${ }^{475}$ Mündchen“ $(K, 14)$ und „Lenas Mund, verschlossen und einen Spaltweit geöffnet, seine Schüchternheit...“ (K, 14) Das Anomale trifft das Normale, zu kurz jedoch wird der Kontrast beider Frauenmünder zur Schau gestellt, deswegen „nichts weiter mehr, wir [Witold und Fuks - K.S.] gingen nach oben.“ $(K, 14)$ Zum zweiten Mal seit der Entdeckung im Dickicht erinnert sich Witold an den gehängten Sperling, die Intensität der um den hängenden Vogel kreisenden Gedanken des Erzählers scheint zuzunehmen, das Erinnern an den Fund verliert ihre Neutralität und fängt an, sich lästig aufzudrängen: „es irritierte, dass sich der Spatz wieder aufdrängte, uns in die Quere kam, sich gleichsam aufplusterte und aufblähte und sich wichtiger tat, als er war - und wenn dieser Dämel $^{476}$ tatsächlich zu ihm gegangen war, dann würde der Spatz schon zu einem Würdenträger werden, der Visiten empfängt!“ (K, 16f) Immer noch finden die Anomalien im Bewusstsein Witolds kein Zueinander, abwechselnd melden sie sich in ihrem Separat-Sein, mal der Spatz, mal der Mund und die Abwesenheit Fuks' lässt Witold keine Ruhe. Das Verlassen des Zimmers und Betreten des dunklen Korridors verdrängt den Vogel und „das schielte zur Sinnlichkeit hin und war vielleicht das gleiche entschlüpfende Ausgleiten zu ihr wie das auf Katasias Lippe...“" ${ }^{477}$ (K, 17) Die Erinnerung an den verzerrten Mund fesselt Witolds Gedanken, er zeigt sich jedoch selber überrascht von den Verbindungen, die assoziativ verknüpft werden:

„,ich dachte >was, die Münder, zusammen?<, und was mich besonders wunderte, war, dass diese Münder, der einen wie der anderen, jetzt in der Vorstellung, in der Erinnerung mehr miteinander verbunden waren als damals bei Tisch, ich schüttelte sogar den Kopf, als wollte

\footnotetext{
${ }^{475}$ Lena ist Tochter der Pensionsbesitzer und wird zum Objekt eines ambivalenten Begehrens des Erzählers. Ihr Vater - Leon, der ehemalige Bankangestellte - wird allmählich zur zentralen Figur Kosmos'.

${ }^{476}$ Gemeint ist Fuks, der in der Nacht das Zimmer heimlich verlässt. Witold vermutet, dass sein Kumpan den Detektiv spielen konnte, um das Geheimnis des aufgehängten Vogels aufzuklären.

477 „ihre lippenhaft-schlüpfrige, kriechtierhafte Verzerrung, ein klein wenig, kaum merklich in Verbindung mit meiner Verstoßung, Verschreckung durch sie dort in Warschau, einer kalten, unangenehmen, stieß mich kalt zu ihrer Schweinerei hin, die hier irgendwo, in dem schlafenden Hause..." (K, 17) Wie das Zitat zeigt, bleiben die Assoziationen zu Katasias Mund konsequent erotischer Natur, sie sind aber nicht die Einzigen.
} 
ich etwas abschütteln, doch davon wurde die Verbindung von Lenas Lippen mit Katasias Lippen deutlicher, also lächelte ich, denn die verstauchte Zügellosigkeit Katasias, dieses Entschlüpfen ins Schweinische, hatte ja gar nichts, aber auch gar nichts mit dem frischen Spaltweitgeöffnetsein der jungfräulichen Verschlossenheit von Lenas Lippen gemein, nur soviel, dass das eine >bezüglich des anderen $<$ war $[\ldots]^{“}(\mathrm{~K}, 18 \mathrm{f})$

Zum ersten Mal versucht der Erzähler seine Assoziationen zu ordnen, die Gedanken zu strukturieren und sich einen Überblick über das Wahrgenommene zu verschaffen: „Die ganze > Verbindung «< war eigentlich keine Verbindung, es war ganz einfach der eine Mund betrachtet in Bezug auf den anderen Mund, im Sinne des Abstands zum Beispiel, der Richtung, der Lage ... nichts weiter ...“ $(K, 19)$ Die gedankliche Konfrontation der beiden Münder scheint aber auch die Anomalie verstärkt zu haben, denn ,lüstern-kaltes Streben zu Katasia in diesem Korridor unterlag einer Verrenkung infolge dieses beiläufigen SichEinmischens von Lena.“ (K, 19) Die hektisch durchgeführte Stilllegung des assoziativen Aufwucherns zeigt sich jedenfalls vor kurzer Dauer, die Abwesenheit Fuks ' evoziert plötzlich den verdrängten Sperling

„und es entstand so etwas wie ein ermüdendes Tennisspiel, denn der Spatz verwies mich auf den Mund, der Mund auf den Spatzen, ich fand mich zwischen Spatz und Mund, das eine schützte das andere vor, sobald ich an den Mund stürzte, beflissen, als wenn ich ihn verloren hätte, schon wusste ich, dass jenseits dieser Seite des Hauses die andere Seite war, jenseits des Mundes der einsam hängende Spatz ... Und das Peinlichste war, dass der Spatz sich nicht mit dem Mund auf einer gemeinsamen Landkarte plazieren ließ, er war vollkommen jenseits, aus einem anderen Gebiet und schließlich auch zufällig, ja ganz ungereimt, warum also war er mir so augenfällig, er hatte kein Recht dazu!“‘ $(K, 20)$

Das unklare Verweisen des Mundes (der Münder?) auf den Spatzen und umgekehrt, das als Resultat eines sich der Logik entziehenden wuchernden Assoziationsdrangs zustande kam, markiert den Anfang einer Obsession ${ }^{478}$, die den Erzähler bis zum Ende des Romans plagen wird.

„Diese beiden Rätsel beginnen nach Sinn zu verlangen. Eins durchdringt das andere, nach Einheit strebend. Es kommt zu einem Prozess von Mutmaßungen, Assoziationen, Indizien, etwas ist am Entstehen, aber ein ziemlich scheußlicher Embryo ... und diese finstere, unfassbare

\footnotetext{
${ }^{478}$ Die Obsession wird stets durch kaleidoskopisch wechselnde Konstellationen von Verweisen entfacht und scheint allmählich die Sinnlichkeit Witolds anzustecken: „Ich geriet in eine Art zitternden Verwunderung, dass Münder, die nichts gemein hatten, doch etwas gemein hatten, diese Tatsache betörte mich und ließ mich in irgendeiner unglaublichen Zerstreutheit versinken $[\ldots]^{\prime \prime}(K, 24)$
} 
Scharade wird nach ihrer Lösung rufen ... wird suchen nach der erhellenden, ordnenden Idee ..,479

An einem heißen Nachmittag entdeckt Fuks an der Zimmerdecke einen wie mit einem Spicknadel eingeritzten Pfeil: „>Wenn es ein Pfeil ist, dann zeigt er auf etwas.<“ (K, 33) Ob es eine Illusion, eine Einbildung war, ,nachprüfen könne schließlich nichts schaden, wenn wir zu dem Schluss kämen, dass er auf nichts zeige, dann hätten wir wenigstens Ruhe, dann wäre klar, dass es kein Pfeil sei, den jemand absichtlich gemacht hat [...]“ (K, 33) Da der Pfeil auf nichts im Zimmer zeigte, machen sich Witold und Fuks auf den Weg nach draußen, um dort die Richtung des Pfeils zu ermitteln. Nach einer kurzen Suche findet Fuks in einer Nische einer zerbröckelten Mauer ein kleines, an einem weißen Faden gehängtes Stäbchen, ,angehakt an eine Ziegelscharte. “480 (K, 37) Der Verweis auf den Vogel scheint offensichtlich zu sein:

„Der gehängte Spatz - das aufgehängte Stäbchen - dieses Aufhängen des Stäbchens an der Mauer, das jenes Aufhängen im Dickicht wiederholte - ein sonderbares Resultat, durch das die Intensität des Spatzen plötzlich wuchs [...] Stäbchen und Spatz, ein stäbchenverstärkter Spatz! Man könnte sich nur schwer des Gedankens erwehren, dass jemand uns mit diesem Pfeil zu dem Stäbchen geführt hatte, um an den Spatzen anzuknüpfen...“ (K, 37f)

Ein Streich (vielleicht Fuks') oder amüsiert sich jemand auf Kosten der Beiden, oder war das Ganze nur ein Zufall?

„Gewiß... aber irgendeine Neigung zur Harmonie, etwas gleichsam vage Anhakendes war in dieser Ereignisfolge zu spüren - gehängter Spatz - gehängtes Hähnchen ${ }^{481}$ - der Pfeil im Eßzimmer - der Pfeil in unserem Zimmer - das am Ende hängende Stäbchen - ein gewisser Drang nach Sinn machte sich in ihnen bemerkbar, wie bei der Scharade, wenn die Buchstaben sich allmählich zu einem Wort zusammenfügen [...] Ja, es schien doch wohl so, als wollte sich alles im Sinne irgendeines Gedankens benehmen...““822 $(\mathrm{K}, 38 \mathrm{f})$

Der Spatz bildet ab jetzt ein klares Verweiszentrum, die Quelle des Verweissystems, von der eine assoziative Ordnung aufgebaut wird. Obwohl das gesamte Prozedere absurd erscheint, gibt es etwas, was das Treiben festigt und ihm einen Hauch der Sinnhaftigkeit verleiht - die

\footnotetext{
${ }^{479}$ Witold Gombrowicz, Tagebuch 1953-1969, München Wien 1988, S. 911.

${ }^{480}$ Die Spezifik der Gegend evoziert wieder die Erinnerung an den Spatzen: „das Vordringen zu diesem Winkel, der ein eigenes Leben führte, knüpfte an jenes dunkel-kühle Dickicht mit dem Pappdeckel und dem Blechstück an - dem Spatzen - gleichsam kraft der Entfernung meldete sich jenes dort in diesem hier wieder - und es war, als lebte unsere Suche hier wieder auf." $(K, 36)$

${ }^{481}$ Von einem „,an einer der Fichten am Wege“ erhängten Hähnchen berichtet Ludwik, Lenas Mann. Vgl. K, 24.

482 Und es ist wieder eine Anormalität, die „eine gewisse Neigung zeigte, an dieser Anormalität anzuhaken“, $(K, 39)$ die Witold die Vermutung des Zufalls verwerfen lässt.
} 
Wiederholung. „Die Repetition, sei es eines Unsinns fixiert eine Art System“, 483 in Kosmos ist es das Verweisen selbst ${ }^{484}$, das zu einem System wird. Eine einzelne Absonderlichkeit bleibt meistens harmlos, wenn sie sich aber mit einer anderen Absonderlichkeit verbindet, initiiert sich spontan eine Reihe. Diese bedarf noch einer Bestätigung in der zwischenmenschlichen Kommunikation, um sich in dieser als ein neues Element verankern zu können. ${ }^{485}$

Die harmlosen Spielchen der aufeinander verweisenden Assoziationen und der sich multiplizierenden Verweise könnten eine erholsame (und trotzdem spannende) Urlaubsbeschäftigung werden, wenn nicht dem fröhlichen Treiben eine neue Atmosphäre beigemischt werden würde - die Atmosphäre des Unheimlichen: „In der Tat ... die Lippe und das Stäbchen schienen verschwägert zu sein, ebenso wie die Lippe und der Spatz, und sei es nur deshalb, weil die Lippe so unheimlich war ...“ $(K, 39)$ Angesichts des Verdachts, Katasia könne die ganze Intrige einfädeln, gewinnen Witolds Assoziationen eine neue dunkle Energie, die bereits getätigten Verweise erwachen mit einer neuen Kraft. ${ }^{486}$ Ist es also die verzerrte Lippe, durch die sich das Unheimliche eingeschlichen hat? Bei einem Abendbrot mit der Familie Wojtys und Katasia nehmen Witolds Gedankengänge stark obsessive, fast paranoide Züge an:

„Ich fühlte mich zwischen Vogel und Stäbchen wie zwischen zwei Polen, und unsere ganze Versammlung bei Tisch, unter der Lampe, kam mir wie eine spezielle Funktion jenes Systems vor, wie >>hinsichtlich<< des Vogels und des Stäbchens - das kam mir gar nicht ungelegen, bahnte diese Unheimlichkeit doch einer anderen Unheimlichkeit den Weg, die mich quälte, aber auch faszinierte. Mein Gott! Wenn der Vogel, wenn das Stäbchen, dann erfahre ich vielleicht am Ende auch, was mit dem Mund ist. (Woher? Wie? Absurd!)“ (K, 47)

Nach dem assoziativen Wirrwarr kommt wiederum eine kurze Phase der Besinnung, in einer Art methodischen Zweifelns schimmert für einen Augenblick in Witolds Gedanken seine problematische geistige Lage: „[...] gerade das war schwierig, schrecklich, irreführend, dass ich nie wissen konnte, in welchem Maße ich selbst der Urheber der Kombinationen war, die sich um mich knüpften [...]“ (K, 56) Witold und Fuks beschließen, Katasias Zimmer zu durchsuchen, es werden jedoch keine klaren Beweise gefunden, ${ }^{487}$ was Witold für einen Moment in Verzweiflung versetzt, der starke Drang nach Sinn scheint nachzulassen, er macht

\footnotetext{
${ }^{483}$ Michał Legierski, Modernizm Witolda Gombrowicza [Modernismus Witold Gombrowicz'], Warszawa 1999, S. 164. [„Repetycja choćby nonsensu ustala rodzaj systemu."]

484 „[...] es ging schließlich um dieses >>Sich-Beziehen<< selbst, das gleichsam eine gewisse Anordnung festlegte." (K, 40)

${ }^{485}$ Vgl. ebd., S. 164.

${ }^{486}$ Vgl. Witold Gombrowicz, Kosmos, S. $39 f$.

${ }^{487}$ Vgl. ebd., S. 60-66.
} 
sich kaum noch bemerkbar. Die Tatenlosigkeit angesichts des schwindenden Sinns war nicht zu ertragen, wenn nicht in diese, dann muss wenigstens in eine andere Richtung gegangen, gedacht werden. In Lenas und Ludwiks Zimmer brennt Licht, von der gegenüber dem Fenster stehenden Fichte könnte man hineinsehen,

„zu Lena vordringen [...], sie zu Gesicht bekommen, sie sehen - sie mit ihm sehen [...] Endlich sah ich. Ich war platt. Er zeigte ihr eine Teekanne. Auf alles war ich gefasst gewesen. Aber nicht auf eine Teekanne. Man muss erlebt haben, was das ist - der Tropfen, der das Fass überlaufen lässt. Was >>zuviel<< ist. Es gibt so etwas wie ein Übermaß an Wirklichkeit, ihr Aufquellen bis zur Unerträglichkeit. (Hervorhebung - K.S.) “(K, 69f)

Eine vollständige Besinnung, ein totales Verzweifeln, ein Schnitt? Witold weiß nicht weiter. Sich von dem unheimlichen, unerträglichen Aufquellen der Wirklichkeit befreien? Aber wie? Das momentane Nachlassen des wuchernden Assoziierens scheint etwas Dämonisches, Unsagbares vorzubereiten; ohne Grund erwürgt Witold Lenas Kater ${ }^{488}$ und hängt ihn an den Haken: „Er hing wie der Spatz, wie das Stäbchen, der Vollständigkeit halber.“ (K, 72) Das Spiel des Sich-Beziehens wird also weiter gespielt, nur ist Witold kein bloßer Detektiv mehr. Die Ermordung des Tieres macht ihn zum Täter und somit zum Zeichenhersteller. Wie es sich zeigt, wird er aber die Rolle des Detektivs, d.h. des Zeichendeutenden nicht aufgeben. Zwischen Produktion und Interpretation der Verweise hin und her gerissen wird der Witoldsche Wahnsinn sichtbar zunehmen, seine Paranoia eskaliert und befreit nach und nach Potentiale der Desorientierung.

Das Geschehen in Kosmos kreiert konsequent eine Atmosphäre einer sich allmählich steigernden, nicht näher beschreibbaren Unruhe. Dieses Phänomen, das ich als ein Unternähen mit Unheimlichkeit bezeichnen würde, wurde bereits im Kontext Kosmos ' (aber nicht nur) von Michał Paweł Markowski originell und einleuchtend untersucht. Der polnische Literaturwissenschaftler untersucht die Spezifik der ontischen Strukturierung der Wirklichkeit in Gombrowicz' Romanen und formuliert folgendes Fazit:

„Die Struktur der Gombrowiczschen Welt ist dreiteilig: Die Welt der heimischen Vertrautheit -1), die von dem Dämonischen heimgesucht wird - 2), das das Subjekt aus seiner vertrauten

\footnotetext{
${ }^{488}$ Alfred Gall sieht in der „Ermordung des Katers [...] eine Reaktion auf den Entzug der Einsicht in die ausgestreuten Spuren." Alfred Gall, Performativer Humanismus. Die Auseinandersetzung mit Philosophie in der literarischen Praxis von Witold Gombrowicz, Dresden 2007, S. $362 f$.
} 
Lebenswelt entwurzelt und es in eine 3) Welt einführt, die mit einer unheimlichen

Vieldeutigkeit unternäht ist, in der das Subjekt von sich selbst weggerückt wird. “489

Der Autor von Kosmos lässt seine Figuren in einer Wirklichkeit leben, die in sich drei ineinander fließende Bereiche verflechtet. Die eigentliche Dynamik der Gombrowiczschen Romane entfaltet sich, wie es scheint, an der Schnittstelle zwischen der Welt der naiven, gewohnten Beziehungen und dem Kosmos, der die heimliche Lebenswelt mit seiner gestaltlosen Strömung unterläuft. Die Invasion des Kosmos` beraubt das Zwischenmenschliche seiner Offensichtlichkeit, auch Gegenstände verlieren ihre gewohnte Verankerung und beginnen anders zu sein. ${ }^{490}$ Die Welt des Unheimlichen bildet sich nach Markowski als Resultat des Aus-dem-Gleichgewicht-Bringens der Welt der heimischen Vertrautheit. Unter Unheimlichkeit versteht er in dieser Optik „die Ansteckung Desselben durch das Andere - oder auch der Angriff der unerwarteten Anwesenheit.“491 Die Originalität der Annäherungsweise Markowskis beruht darauf, dass er von der Freudschen Konzeptualisierung des Unheimlichen ausgehend, diese um eine neuartige - man möchte sagen postmoderne - Dimension anreichert. Im Folgenden werden Freuds und Markowskis Konzepte der Unheimlichkeit skizziert und das gewonnene Wissen bei der Lokalisierung der unheimlichen Momente in Kosmos erprobt. Erwartet wird dabei die Bestätigung der These die Verdichtung von Unheimlichkeiten trage maßgeblich zur Verwirrung und folglich zur Desorientierung des Lesers bei.

\footnotetext{
${ }^{489}$ Michał Paweł Markowski, Czarny nurt Gombrowicz, świat, literatura. [Die schwarze Strömung Gombrowicz, Welt, Literatur] Kraków 2004, S. 46. [„Struktura Gombrowiczowskiego świata jest trójdzielna: świat domowej swojskości - 1) bywa nawiedzany przez demoniczność - 2), która wywłaszcza podmiot z oswojonej przestrzeni życia i wprowadza go $w-3$ ) świat podszyty niesamowitą wieloznacznością, w którym podmiot ów zostaje odsunięty od samego siebie."]

${ }^{490}$ Vgl. ebd., S. 37.

${ }^{491}$ Ebd., S. 72. [„To zarażenie tego samego przez to, co inne - albo też napad nieoczekiwanej obecności wypada nazwać niesamowitością."]
} 


\subsubsection{Das Unheimliche im Kontext der Psychoanalyse}

Es war Sigmund Freuds Aufsatz Das Unheimliche aus dem Jahre 1919, der das Thema zum ersten Mal tiefenpsychologisch zu erforschen versuchte und der in den nächsten Jahrzehnten zum obligatorischen Text für alle Forscher der Geisteswissenschaften wurde, die die dieses Phänomen zu ergründen suchten. Der Gründer der Psychoanalyse war zwar nicht der erste, der das Gefühl der Unheimlichkeit theoretisch erfassen wollte, seine Intuitionen und die Fülle der Beispiele übertrafen jedoch wesentlich die Leistung seiner Vorgänger ${ }^{492}$. Was Freuds Aufsatz vor allem zeigte, ist der Nuancenreichtum des Begriffs und des Gefühls des Unheimlichen. Die 2003 präsentierte Monographie The Uncanny von Nicolas Royle macht deutlich, dass die Unheimlichkeit als ein Wahrnehmungsphänomen heutzutage in fast jeder Disziplin der Geisteswissenschaften erforscht wird. Als falsch erweist sich nach Freud zunächst Jentschs Behauptung, „die wesentliche Bedingung für das Zustandekommen des unheimlichen Gefühls [liege - K.S.] in der intellektuellen Unsicherheit. Das Unheimliche wäre eigentlich immer etwas, worin man sich sozusagen nicht auskennt.“493 Diese Gleichung - unheimlich $=$ nicht vertraut lässt sich nach Freud nicht aufrechterhalten. Als ,Meister des Unheimlichen in der Dichtung ' nennt Freud E.T.A. Hoffmann ${ }^{494}$ und weist auf seine Strategie hin, viel Gleichartiges anzuhäufen, was den Leser schnell zur Verwirrung führt. In der Wiederholung des Gleichartigen lässt sich somit eine mögliche Quelle der Unheimlichkeit finden, diese muss jedoch ,unter gewissen Bedingungen und in Kombination mit bestimmten Umständen“ “495 strukturiert werden. Wichtig ist zum Beispiel, dass es sich dabei um eine unbeabsichtigte „Wiederholung handelt, welches das sonst Harmlose unheimlich macht und uns die Idee des Verhängnisvollen und Unentrinnbaren aufdrängt, wo wir sonst nur von >Zufall< gesprochen hätten.“496 Aus der psychoanalytischen Kontextualisierung kann Freud „das Unheimliche der gleichartigen Wiederkehr aus dem infantilen Seelenleben““497 ableiten.

\footnotetext{
${ }^{492}$ Es war Ernst Jentsch, der bereits 1906 die Arbeit Zur Psychologie des Unheimlichen verfasste.

${ }^{493}$ Sigmund Freud, Das Unheimliche (1919), in: Sigmund Freud, Psychologische Schriften B. IV, Frankfurt am Main 1970, S. 244. Da das Adjektiv heimlich nicht eindeutig ist und entweder auf vertraut, behaglich oder auf versteckt, verborgengehalten verweist, macht Freud klar: „Unheimlich sei nur als Gegensatz zur ersten Bedeutung [...] gebräuchlich." Ebd., S. 248.

${ }^{494}$ Eine präzise Untersuchung führt Freud anhand der Erzählung Sandmann durch, mit dem Ziel, Momente der unheimlichen Wirkung des Werkes zu lokalisieren und zu beschreiben. Die Ergebnisse dieser Analyse haben jedoch keine Bedeutung für meine Untersuchung.

${ }^{495}$ Ebd., S. 259.

${ }^{496}$ Ebd., S. 260.

${ }^{497}$ Ebd., S. 261. „Im seelisch Unbewussten lässt sich nämlich die Herrschaft eines von den Triebregungen ausgehenden Wiederholungszwanges erkennen, der wahrscheinlich von der innersten Natur der Triebe selbst abhängt, stark genug ist, sich über das Lustprinzip hinauszusetzen, gewissen Seiten des Seelenlebens den dämonischen Charakter verleiht, sich in den Strebungen des kleinen Kindes noch sehr deutlich äußert und ein
} 
Schlussfolgernd kann er also behaupten, seine Untersuchungen haben zur alten Weltauffassung des Animismus zurückgeführt ${ }^{498}$ und ,alles, was uns heute als >> unheimlich<< erscheint, die Bedingung erfüllt, dass es an diese Reste animistischer Seelentätigkeit rührt und sie zur Äußerung anregt.، “499

Aus dem bisher Gesagten durfte der Begründer der Psychoanalyse seine Hauptthese aufstellen: Das „Unheimliche ist wirklich nichts Neues oder Fremdes, sondern etwas dem Seelenleben von alters her Vertrautes, das ihm nur durch den Prozess der Verdrängung entfremdet worden ist. ${ }^{\text {“500 }}$ Freuds psychoanalytische Erfahrung lässt ihn außerdem das Gefühl des Unheimlichen mit den psychischen Neigungen des Neurotikers assoziieren. Es ist für neurotische Fälle typisch, die psychische Realität gegenüber der materiellen überzubetonen, was wiederum oft das Anschließen der Allmacht der Gedanken provoziert. ${ }^{501}$

Ein weiterer Schritt, der für ein tiefgründiges Verständnis der Wahrnehmung des Unheimlichen erforderlich war, war das Thematisieren des Unterschieds

„Zwischen dem Unheimlichen, das man erlebt, und dem Unheimlichen, das man sich bloß vorstellt oder von dem man liest: ${ }^{502}$ [...] Das Unheimliche des Erlebens kommt zustande, wenn verdrängte infantile Komplexe durch einen Eindruck wieder belebt werden oder wenn überwundene primitive Überzeugungen wieder bestätigt scheinen. [...] Das Unheimliche der Fiktion - der Phantasie, der Dichtung - verdient in der Tat eine gesonderte Betrachtung. Es ist vor allem weit reichhaltiger als das Unheimliche des Erlebens, es umfasst dieses in seiner Gänze und dann noch anderes, was unter den Bedingungen des Erlebens nicht vorkommt. Der Gegensatz zwischen Verdrängtem und Überwundenem kann nicht ohne tiefgreifende

Stück vom Ablauf der Psychoanalyse des Neurotikers beherrscht. Wir sind [...] darauf vorbereitet, dass dasjenige als unheimlich verspürt werden wird, was an diesen inneren Wiederholungszwang mahnen kann."

S. 261. Die Manifestationen des Wiederholungszwangs wurden von Freud in seinem Werk Jenseits des Lustprinzips analysiert. Weitere angeführte Beispiele weisen weiterhin darauf hin, dass das Unheimliche auch aus einem Prinzip resultiert, das Freud ,Allmacht der Gedanken' bezeichnet. (Näheres dazu, S. 262f.)

498 „die ausgezeichnet war durch die Erfüllung der Welt mit Menschengeistern, durch die narzißtische Überschätzung der eigenen seelischen Vorgänge, die Allmacht der Gedanken und die darauf aufgebaute Technik der Magie, die Zuteilung von sorgfältig abgestuften Zauberkräften an fremde Personen und Dinge (Mana) sowie durch alle die Schöpfungen, mit denen sich der uneingeschränkte Narzißmus jener Entwicklungsperiode gegen den unverkennbaren Einspruch der Realität zur Wehr setzte. Es scheint, dass [...] sie[dem Animismus entsprechende Phase - K.S.] bei keinem von uns abgelaufen ist, ohne noch äußerungsfähige Reste und Spuren zu hinterlassen [...] Ebd., S. 263.

${ }^{499}$ Ebd., S. 263.

${ }^{500}$ Ebd., S. 264. Dieser Schluss erinnert uns an die von Freud zitierte Definition von Schelling: „das Unheimliche sei etwas, was im Verborgenen hätte bleiben sollen und hervorgetreten ist." Diese einleuchtende These markiert den ersten großen Schritt zum Verständnis der Unheimlichkeit. Auch sie bedarf jedoch, was Freud schnell bemerkt, einer weiteren Präzisierung und Erweiterung. Es muss vor allem angemerkt werden, dass nicht alles Heimliche, was verdrängt wurde und aus der Verdrängung wiedergekehrt ist, als unheimlich wahrgenommen wird. Vgl. ebd., S. 268.

${ }^{501}$ Vgl. ebd., S. 267.

502 Ebd., S. 269. 
Modifikation auf das Unheimliche der Dichtung übertragen werden, denn das Reich der Phantasie hat ja zur Voraussetzung seiner Geltung, dass sein Inhalt von der Realitätsprüfung enthoben ist. Das paradox klingende Ergebnis ist, dass in der Dichtung vieles nicht unheimlich ist, was unheimlich wäre, wenn es sich im Leben ereignete, und dass in der Dichtung viele Möglichkeiten bestehen, unheimliche Wirkungen zu erzielen, die fürs Leben wegfallen." ${ }^{\text {503 }}$

Um die Effektivität des gewonnenen Wissens zur Sondierung des Potentials des Unheimlichen in Kosmos einzuschätzen, muss noch eine Anmerkung angeführt werden, die Freud über literarische Werke formulierte, in denen der Leser mit einer gemeinen Realität zu tun hat. In solchen Fällen (und einen solchen Fall stellt auch Kosmos dar) werden auch alle Bedingungen übernommen, die im Erleben das Gefühl der Unheimlichkeit wachrufen können. Die Literatur liefert jedoch eine unvergleichbar breitere Palette von Mitteln zur Steigerung und Vervielfältigung der unheimlichen Momente. ${ }^{504}$ Von Bedeutung wird hier z.B. die Möglichkeit, das Gefühl des Unheimlichen mit anderen Gefühlen zu vermengen.

Um die Natur der Unheimlichkeit zufriedenstellend entschlüsseln zu können, müssten m.E. nur noch ihre mögliche Dauer und ihre Erscheinungsweise reflektiert werden. Gordon C.F. Bearn kommentiert Wittgensteins Bemerkungen zum Gefühl des Unheimlichen wie folgt:

"If the world comes to seem uncanny, this will not happen gradually, reasonable doubt by reasonable doubt; it will come all of a sudden. It will be prepared of course, like an avalanche, but when it comes, it comes all at once. The uncanniness comes as a revelation."

Der Gebrauch des Freudschen Konzepts des Unheimlichen, das im Rahmen der Psychoanalyse und mit Hilfe ihrer Begrifflichkeit entwickelt, und das zur Leitidee bei der Herausarbeitung der Deutung dieses Kapitels wurde, bedarf einer Erklärung. Es ist vor allem

\footnotetext{
${ }^{503}$ Ebd., S. 271f. Die im letzten Satz formulierte These, die meines Erachtens die zweite Hauptthese zur Unheimlichkeit präsentiert, findet ihre Bestätigung in den Märchen: „[...] für die Entstehung des unheimlichen Gefühls ist, wie wir gehört haben, der Urteilsstreit erforderlich, ob das überwundene Unglaubwürdige nicht doch real möglich ist, eine Frage, die durch die Voraussetzungen der Märchenwelt überhaupt aus dem Wege geräumt ist." Ebd., S. 272. Die Unheimlichkeit bleibt auch erspart in Fällen, in denen der Dichter in der von sich erschaffenen Welt übernatürliche Existenzformen handeln lässt „als wären sie vollberechtigte Existenzen, wie wir es selbst in der materiellen Realität sind.“ Ebd., S. 272.

${ }^{504}$ Vgl. Ebd., S. $272 f$.

${ }^{505}$ Gordon C.F. Bearn, Wittgenstein and the Uncanny, Soundings: An interdsiciplinary Journal, vol.76, no.I, 1993, zit. nach: Nicolas Royle, The Uncanny, Manchester and New York, 2003, S. 320. Wittgenstein hinterließ keinen nennenswerten Beitrag zum Phänomen der Unheimlichkeit. Seine Bemerkungen markieren jedoch die Zweifel, die weitere Analysen dieses Gefühls beheben sollten: „Das Gefühl des Unheimlichen. Wie zeigt es sich? Die Dauer so eines ,Gefühls'. Wie, z. B., sieht eine Unterbrechung des Gefühls aus? Wäre es, z.B., möglich, abwechselnd eine Sekunde es zu haben, und wieder nicht zu haben? Ist nicht unter seinen Merkmalen auch eine charakteristische Art des Verlaufs (Beginns und Endes), die es z.B. von einer Sinneswahrnehmung unterscheidet?" Ludwig Wittgenstein, Bemerkungen über die Philosophie der Psychologie. Letzte Schriften über die Philosophie der Psychologie, Frankfurt am Main 1989, S. 16.
} 
zu fragen, ob der Gebrauch einer Kategorie in der Form, in der sie in der Psychoanalyse konzipiert wurde, in einer Arbeit, die keine psychoanalytische oder psychoanalytischliteraturwissenschaftliche Annäherung repräsentiert, sinnvoll und gerechtfertigt sein kann. Solches Vorgehen entspräche der Taktik einer ,partialen Deutung“, d.h. einer „Verbindung eines einzelnen Textelements mit einem psychoanalytischen Theorem. “506 Der Gegner der Anwendung solcher Verfahren - Walter Schönau - schätzt den Erklärungswert solcher Deutungen als gering ein und bezweifelt die Möglichkeit, durch solche isolierte Diagnosen sich dem Textverständnis anzunähern. ${ }^{507}$ Schönaus Meinung nach, stellen nur „integrative Deutungen [...] den Idealfall einer möglichst vollständigen konsistenten Texterklärung dar, in der der sinnvolle Zusammenhang aller Themen und Bilder erkannt wird und alle Textelemente ihren eigenen Platz bekommen.“" ${ }^{508}$ Aus zwei Gründen wird jedoch die in diesem Kapitel durchgeführte Untersuchung keine psychoanalytisch ,integrative“ Deutung liefern können. Erstens ist es die mangelnde psychoanalytische Kompetenz des Autors der vorliegenden Arbeit, wegen der die Perspektive dieser Disziplin, d.h. „,analog zur Traumdeutung vom manifesten Gehalt zur $>$ Tiefenstruktur $<$ vordringen [zu] wollen ${ }^{\text {“509 }}$, nicht erfolgreich herausgearbeitet werden könnte. Zweitens birgt m.E. die Annäherungsweise der psychoanalytischen Literaturtheorie im Fall der Untersuchung solch eines verwirrendes Textes wie Kosmos ein besonders hohes Risiko des beliebigen Hineinprojizierens psychoanalytischer Deutungen. ${ }^{510}$ Im Gegensatz zu Schönau würde ich aber den Gebrauch der ,partiellen“ psychoanalytischen Deutung als sinnvoll und fruchtbar erklären. Im Fall des Konzepts der Unheimlichkeit scheint die Kenntnis des Begriffs der Verdrängung völlig ausreichend, um das Zustandekommen dieses Gefühls begreifen und nachvollziehen zu können. Die Ideen Bearns und Markowskis zeigen dabei, dass ein aus der Psychoanalyse stammendes Theorem originelle (und für die Literaturwissenschaft fruchtbare) Ergänzungen erfahren kann. Ich hoffe, dass ich der Skepsis Schönaus zum Trotz zu zeigen vermag, dass auch ein isoliertes Anwenden eines psychoanalytischen Theorems, d.h. ohne konsequente Verknüpfung mit den der Psychoanalyse zugrunde liegenden Mechanismen, seine Absicht, d.h. die Lieferung einer plausiblen Textdeutung erreichen kann.

\footnotetext{
${ }^{506}$ Walter Schönau, Einführung in die psychoanalytische Literaturwissenschaft, Stuttgart 1991, S. 91.

${ }^{507}$ Vgl. ebd.

${ }^{508}$ Ebd.

${ }^{509}$ Ebd., S. 105.

510 Diese Gefahr lässt sich nach Schönau erheblich eindämmen, indem man „eine systematische Heuristik“ explizit macht und die inter- und intratextuelle Konsistenz im Auge behält. (Vgl. ebd.) Diese Forderung kann leider m.E. in den meisten postmodernen Texten nicht erfüllt werden.
} 
Bevor der Kosmos-Text auf der Suche nach lauernden Unheimlichkeiten durchsucht wird, sollte zuerst dasjenige Unheimliche herausgefischt werden, das von dem Erzähler selbst thematisiert wird. Zum ersten Mal verspürt Witold Unheimliches während der Erinnerung an die verzerrte Lippe Katasias, kurz danach wurde Witold unheimlich zumute angesichts des Eindrucks des sich rätselhaft konstituierenden Systems der aufeinander verweisenden Elemente, der kaputte Mund scheint jedoch in das System noch nicht integriert zu sein, er musste erst in die Verweiskette hineinassoziiert werden. ${ }^{511}$ Warum verspürt der Erzähler Unheimliches erst jetzt, wenn er doch Katasias Lippe sowie den Spatzen und das Stäbchen bereits zum x-ten Mal assoziiert?

Wie vor Kurzem erwähnt, lässt sich das Phänomen des Unheimlichen durch einen Nuancenreichtum charakterisieren, dessen Entfaltung besonders in der Literatur bemerkbar wird. Es wäre daher falsch, Unheimlichkeit als nur ein momentanes Gefühl einer Romanfigur zu betrachten denn

„the uncanny is not simply an experience of strangeness or alienation. More specifically, it is a peculiar commingling of the familiar and unfamiliar. It can take the form of something familiar unexpectedly arising in a strange and unfamiliar context, or of something strange and unfamiliar unexpectedly arising in a familiar context." ${ }^{, 512}$

Witolds Verspüren des Unheimlichen muss daher durch eine Vorbereitungsphase eingeleitet werden, es kommt zwar plötzlich, es braucht aber eine gewisse Zeit, bis es sich als solche manifestiert, ihren direkten Anreiz schafft jedoch ein gewisser Wiederholungszwang. Warum ist es aber die Lippe, die das Gefühl hervorrief? Warum nicht der exzentrische Spatz, der auch noch durch das Stäbchen verstärkt wird? Das Rätsel des verzerrten Mundes lässt sich meines Erachtens lösen, indem man bedenkt, wie stark erotisch dieser Körperteil in Kosmos gefärbt wird. Von Anfang an weckt Katasias Lippe Witolds wollüstige Begierden, obwohl sie in Gänze (im Gegensatz zu Lena) kein Sexualobjekt für ihn war. Die anomale Lippe, die allem Anschein nach auf weibliche Genitalien verwies, musste verdrängt werden und kommt aus der Verdrängung verstärkt zurück. Ich würde an dieser Stelle eine Interpretation wagen, dass es sich im Falle des Mundes um eine doppelte Verdrängung handelt: Erstens geht es um die einst verdrängte Assoziation des weiblichen Genitals ${ }^{513}$, zweitens wird der kaputte und auch ungewollte Mund durch den perfekten, begehrenswerten Mund Lenas verdrängt. Aus der verdoppelten Verdrängung resultiert meines Erachtens die Kraft der Unheimlichkeit, die der

\footnotetext{
${ }^{511}$ Vgl. die bereits von mir zitierten Passagen aus Kosmos, S. 39 u. 47, hier S. $134 \mathrm{f}$.

512 Nicolas Royle, The Uncanny, Manchester and New York 2003, S. 1.

${ }^{513}$ Dieses Beispiel führt im Kontext der Analyse zur Unheimlichkeit auch Markowski an, ohne es jedoch direkt auf Kosmos zu beziehen. Vgl. Michał Paweł Markowski, a.a.O., S. 84.
} 
geschädigten Lippe zugeschrieben wird. Ich will dadurch jedoch nicht sagen, dass die Exzentrik des auf dem Draht im Dickicht baumelnden Spatzen nichts Unheimliches produziert. Das Verspüren der Unheimlichkeit lässt sich aber skalieren, somit wird in erster Linie Dasjenige als unheimlich wahrgenommen, was intensiver aus der Verdrängung zurückkommt. Im Falle Witolds wird also Katasias Lippe zum permanenten Epizentrum des Unheimlichen (zumal er von ihr jeden Tag geweckt wird) und die obsessiven Versuche des Erzählers, den Mund/die Münder in das System des Sich-Verweisens hineinzumontieren, fängt an eine zunehmende Verwirrung zu stiften.

Das Treiben der Unheimlichkeit beherrscht allmählich virusartig das ganze Geschehen Kosmos`. Nach der Invasion des aus der Verdrängung Zurückgekehrten gab es nämlich kein Zurück mehr, das Heimliche ging verloren, für immer. Der Witoldsche Wiederholungszwang wird zum Zwang des Kreierens, der Herstellung von Verweisen, die hängende Katze verstärkt den hängenden Spatzen, verstärkt das hängende Stäbchen, legitimiert das System. Zwischen dem Rechtfertigen seiner Tat (vor sich selber) und der glimmenden Verblüffung, dass er selber der Würger der Katze ist, hin und her gerissen, erkundet Witold vorsichtig seine Lage, die „alle Anzeichen eines Sprungs ins Unbekannte“ (K, 74) aufweist. Spätestens hier müsste sich der Leser angesichts der chaotisch wechselnden Perspektiven, aus denen der Erzähler über das Wahrgenommene berichtet, darüber Gedanken machen, welche Position (und wie lange) gültig bleibt und wer gerade - der Erlebende oder der das Erlebte Kommentierende die reale Oberhand gewinnt. In dem ganzen Roman ist die Perspektive Witolds die einzige, aus der erzählt wird. In die Innenwelt anderer Figuren wird nicht eingedrungen, ${ }^{514}$ obwohl der Erzähler sich ab und zu in wilden Spekulationen über Gefühle Anderer verlieren mochte. Die Erzählinstanz erfährt jedoch im Laufe des Kosmos-Geschehens eine sich zunehmend dynamisierende Spaltung, die die erzählerische Sinnstiftung maßgeblich beeinträchtigt. Es wäre daher als erstes zu fragen, ob Witold die Geschehnisse genauso darstellt, wie er sie erfasst. $^{515}$ „[S]eine Geschichte konstituiert sich überhaupt erst dadurch, dass das amorphe, kontinuierliche Geschehen einer selektierenden und hierarchisierenden Hinsicht unterworfen wird. ${ }^{\text {516 }}$ Dieser Prozess scheint in Kosmos doch mit dem Beibehalten der Kongruenz vom Erfassen und Darstellen zu verlaufen, d.h. der Erzähler gibt wieder „,was und wie er selbst wahrgenommen hat ${ }^{\text {“517 }}$, obwohl er seine subjektive Wahrnehmung als die der Hauptfigur

\footnotetext{
${ }^{514}$ Vgl. Birgit Harreß, Die Dialektik der Form. Das mimetische Prinzip Witold Gombrowicz'., Frankfurt am Main 2001, S. 144.

${ }^{515}$ Vgl. Wolf Schmid, S. $129 f$.

${ }^{516}$ Ebd., S. 129.

${ }^{517}$ Ebd., S. 130.
} 
reproduziert. Die Quelle der Verwirrung ist also irgendwo anders zu situieren und zwar in der dynamischen Vermengung von Äußerungen des homodiegetischen Erzählers, der das Romangeschehen mit zunehmender Intensität abwechselnd erlebt und korrigierend kommentiert. Ich bin davon überzeugt, dass die Darstellung des Romangeschehens in Form eines objektiven Berichts dem Erzähler besonders am Herzen lag. Seine sich allmählich vertiefende Involviertheit in die Angelegenheiten der Verweise, sein hyperaktives detektivisches Engagement, das wahnhafte Züge aufzuweisen beginnt, entgleist ihn aus der Rolle eines, das Wahrgenommene bloß protokollierenden Beobachters. Der erlebende (subjektive) Witold liefert also eine unterschiedliche Erfassung des Geschehens von der des korrigierenden Witolds, sie nehmen also verschiedene ideologische Perspektiven an. ${ }^{518}$ Diese Fokussierung unterschiedlicher Momente der Ereignisse in der Vermengung der Perspektiven und das daraus resultierende Verwirrungspotential intensivieren sich eben nach der Ermordung des Katers. Die Untersuchung der erwürgten Katze durch alle Pensionsbewohner und Fuks, zu der auch Witold seine verlogene Teilnahme hinzufügt, wird mit einer chaotischen Dynamik erzählt, die die Aufmerksamkeit auf Seiten des Lesers stark herausfordert. Nach der kurzen genießerischen Beobachtung Lenas (während der Witolds Gefühle zwischen Irritation, Wut und Lust wechseln), in der in völlig absurder Logik das Gefühl des Schams abgelesen wird, verrät uns der Erzähler Einzelheiten seiner neuen privilegierten Position ,auf der anderen (unterstrichen - K.S.) Seite“ (K, 75): „Als hätte mich der Kater von der einen Seite der Medaille auf die andere verschoben, in jene Sphäre, wo sich Geheimnisse taten, in die Sphäre der Hieroglyphe.“ (K, 75) Dieser auf den ersten Blick intrigierende Gedanke verliert jedoch schnell den Charakter eines nüchternen Bewusstseins, indem das Erscheinen Katasias Witolds Assoziationen in den Wahnsinn treibt:

\footnotetext{
${ }^{518}$ Vgl. ebd., S. 131f. „Die ideologische Perspektive umfasst verschiedene Faktoren, die das subjektive Verhältnis des Beobachters zu einer Erscheinung bestimmen: Das Wissen, die Denkweise, die Wertungshaltung, den geistigen Horizont. Abhängig von Faktoren werden Beobachter je andere Momente des Geschehens fokussieren und infolgedessen unterschiedliche Geschichten bilden." Ebd., S. 132. Die für die Bestimmung dieser Perspektive grundlegende Frage: „Mit wessen Augen blickt der Erzähler auf die Welt?“ Ebd., S. 136. wird hier schnell beantwortet: Ausschließlich mit seinen Augen. Als problematisch erweist sich jedoch nähere Bestimmung der perzeptiven Perspektive, wenn der Erzähler zugleich die Hauptfigur ist und sein Erzählen wiederholt die Form einer Introspektion annimmt. Schmid schlägt vor, die perzeptive Perspektive als narratorial zu bezeichnen, „gleichgültig, wie markiert und subjektiv der Erzähler ist.“ Ebd, S. 142. Somit wäre die Frage der perzeptiven Perspektive in Kosmos erledigt. Was mich in Schmidschen Vorschlag ein wenig beunruhigt, ist die Bedingung für die Bestimmung einer narratorialen perzeptiven Perspektive. Es darf hier „keine Anzeichen für eine Brechung der Welt durch das Prisma einer oder mehrerer Figuren.“ Ebd., S. 142. geben. Eine solche Brechung der Welt ist aber meines Erachtens in Kosmos sichtbar und diese resultiert eben aus der Spaltung der Erzählinstanz. Interessant ist hier die Tatsache, dass die Wahrnehmungsinstanz gleich bleibt, die Spaltung vollzieht sich erst im Akt des Erzählens.
} 
„Ihr >>manieriertes<< Mündchen näherte sich dem Katzenmaul - ich spürte, wie sie im Kommen spürte, dass sie etwas diesem Maul Verwandtes an sich trug, das verschaffte mir eine plötzliche Genugtuung, als hätte mein Kater sich solide auf jener (unterstrichen - K.S.) Seite angesiedelt. [...] sie näherte sich mit schlüpfrigem Entgleiten, verrenkt und niederträchtig, eine seltsame Ähnlichkeit im Schweinischen trat auf [...] $(\mathrm{K}, 76)$

Der Wahnsinn des Auf-sich-Beziehens gewinnt noch an Kraft, als Witold in seine entzückte Erschütterung auch noch Lena miteinbezieht: „[...] ich fühlte, dass Lenas Scham mit dem Aufgehen dieser mündlichen Verderbtheit über dem Kater wuchs. Und dank ihrer Scham verband sich der Kater mit der Lippe $[\ldots]^{\text {“ }}(\mathrm{K}, 76)$ Wie verblüffend müssen daher die letzten Worte dieses Monologs erscheinen, in denen der Erzähler behauptet, mit Lenas Scham seine Hirngespinste bestätigt zu haben. Die geschilderte Situation illustriert, meiner Meinung nach, ein Beispiel einer subtilen Falle, die den Leser schnell zur Desorientierung führt. Der ganze Trick wird jedoch schrittweise vorbereitet und dem Leser in Häppchen serviert, bis die oben präsentierte Textstelle seinen Willen zum Verstehen zur Kapitulation zwingt. Vor etwa 40 Seiten eröffnete der Erzähler ein neues Romankapitel mit folgendem Geständnis:

„Ich kann das nicht erzählen ... diese Geschichte ... weil ich sie ex post erzähle. [...] Und wie soll man anders als ex post erzählen? Kann also niemals wirklich etwas ausgedrückt, in seinem anonymen Werden gezeigt werden, wird nie jemand in der Lage sein, das Gestammel des entstehenden Augenblick wiederzugeben, wie kommt es, dass wir, aus dem Chaos geboren, es doch nie zu fassen kriegen, kaum schauen wir hin, schon entsteht Ordnung unter unserem Blick ... und Gestalt ... Macht nichts. Sei es, wie es wolle.” (K, 30f)

Diese auf den ersten Blick ernst geäußerte Skepsis ${ }^{519}$ eines Erzählers über seine narrativen Grenzen illustriert, wie Arkadiusz Kalin zu Recht bemerkt, die erzählerische Spezifik des Romans. Die metanarrativen Unterbrechungen der Handlung komplizieren und stören das Erleben des Erzählers durch redigierende und ordnende Kommentare ${ }^{520}$ und lassen ihn widersprüchliche Varianten seiner Rolle erwägen. Wegen der Unmöglichkeit, anders als ex post zu erzählen, scheint der Erzähler jedoch nicht zu verzweifeln. Mit List und Tücke

\footnotetext{
${ }^{519}$ Einen ähnlichen Kommentar finden wir 16 Seiten vom Ende des Romans: „Es wird schwierig sein, den weiteren Verlauf dieser meiner Geschichte zu erzählen. Ich weiß überhaupt nicht, ob das eine Geschichte ist. So ein ständiges ... Ansammeln und Zerfallen ... von ... Elementen kann man schwerlich als Geschichte bezeichnen." (K, 166) Ich bin der Meinung, dass der an dieser Stelle geäußerte Zweifel nicht mehr als ernst genommen werden kann. Anderer Meinung ist aber Zbigniew Wilkiewicz, Personendarstellung und Menschbild im ,Kosmos' Witold Gombrowicz', Mainz 1986. Vgl. S. 20.

${ }^{520}$ Vgl. Arkadiusz Kalin, Chaos Kosmosu Gombrowicza [Das Chaos des Kosmos' Gombrowicz'], in: Witold Gombrowicz. Nasz współczesny. [Witold Gombrowicz. Unser Zeitgenosse], Kraków 2010, S. $427 f$.
} 
entfaltet er eine Strategie, die einerseits das Geschehen in statu nascendi registriert, andererseits aber korrigiert sie das oft in Form eines Gestammels hervorgebrachte Erleben.

Es wäre m.E. nicht verfehlt diese erzählerische Taktik im Kontext „der Dynamik zwischen unbewußten und bewußten Prozessen, zwischen Ausdruckswillen und Hemmungen im Schaffensvorgang“ 521 zu situieren und durch das Einschalten der psychoanalytischen Perspektive eine zusätzliche plausible Deutung der verwirrenden Erzählsituationen zu gewinnen. In dieser Optik entsprächen die mentalen Aktivitäten des erlebenden und des redigierend-ordnenden Erzählers den zwei Phasen des Schaffensaktes, dem ,Primär`- und dem ,Sekundärvorgang‘. Der ,Primärvorgang“ thematisiert „die assoziative Funktionsweise der Psyche, wie sie sich im Traum und im Wahn manifestiert, wenn die Psyche also nicht nach den Gesetzen der Logik und den Regeln der Realitätsprüfung, sondern mit den unbewußten Mechanismen der Verschiebung und der Verdichtung operiert.“ “522 Im ,Sekundärvorgang“ bemüht sich dagegen die Psyche „um eine angemessene Wahrnehmung und Berücksichtigung

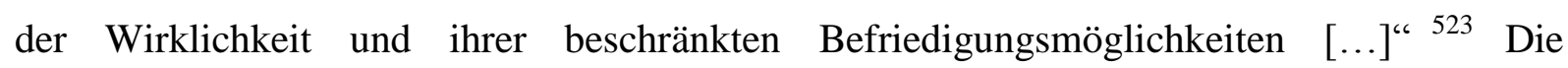
Beschreibung der Zusammenarbeit der beiden Vorgänge, mit der Annahme, der Primärvorgang kennzeichne das Unbewusste, der Sekundärvorgang dagegen das Vorbewusst und Bewusste, gehört zu den schwierigsten Aufgaben der Psychoanalyse. ${ }^{524}$ Als äußerst schwierig müsste sich daher der Versuch erweisen, die vorbewussten, bewussten und unbewussten Struktur- und Inhaltselemente Kosmos ‘ zu untersuchen und die „Lokalisierung der Textphänomene im psychischen System, also nach ihrem Verhältnis zu den psychischen Instanzen Es, Ich und Über-Ich“'525 $\mathrm{zu}$ analysieren. Erzähltechnisch würde jedenfalls solche Vermengung oder eher Zusammenarbeit des ,Primär'- und ,Sekundärvorgangs' konsequent Verwirrung stiften, da das Verfolgen und Erfassen der sich dynamisch wechselnden Perspektiven sowohl das Gedächtnis als auch die Aufmerksamkeit des Lesers herausfordern wird.

Das raffiniert erzeugte, d.h. das aus der Vermengung der sich gegenseitig unterlaufenden Perspektiven resultierende Chaos beansprucht mehr und mehr die leserliche Aufmerksamkeit bis sie eine Dynamisierung erfährt, die den Leser ins Desorientiertsein bringen müsste. Diesen kritischen Grad erreicht die Dynamisierung meines Erachtens zum ersten Mal bei der oben

\footnotetext{
${ }^{521}$ Walter Schönau, a.a.O., S. 15.

522 Ebd.

523 Ebd.

${ }^{524}$ Vgl. ebd., S. 15f. Siehe als Beispiel den Vorgang der Witzbildung, von Schönau kurz erwähnt auf S. 16.

${ }^{525}$ Vgl. ebd., S. 83.
} 
geschilderten Untersuchung der Katzenleiche. Die erste Verwirrung stiften ${ }^{526}$ die kursiv geschriebenen Adjektive , andere‘ und, jene', mit denen Witold die Seite beschreibt, auf der er sich nach dem Erwürgen der Katze fand. Dass er jetzt „nicht mehr mit ihnen, sondern gegen sie war" (K, 75) suggeriert ein früheres Zusammensein aller Figuren. Von Anfang an jedoch war der Erzähler in einer gewissen Gegenposition zu den Anderen, seine Beobachtungen, Entdeckungen und Konstatierungen entfalteten sich im Geheimen, und selbst sein Vertrauter Fuks durfte lediglich zu einem kleinen Bereich des Wahrgenommenen zugelassen werden. Die Kursivschreibung kann daher entweder als Lenkung der Aufmerksamkeit auf eine nur scheinbar bedeutungsvolle Tatsache gedeutet werden oder aber, was nicht ausgeschlossen werden darf, auf die wahnartige Überzeugung Witolds hinweisen, das Erwürgen der Katze wäre eine Art Einweihung in eine Wahrnehmungsrealität gewesen, die den anderen Figuren verschlossen bleibt. Kritisch ist dabei, was ich hier betonen möchte, die sich in immer dichteren Verflechtungen allmählich verwischende Grenze zwischen dem rein erlebenden und dem nüchtern kommentierenden Erzähler, zumal das Treiben des Aufeinander-Verweisens wahnsinnige Züge aufzuweisen beginnt. Die Verwirrung, die der ganze chaotische Monolog entfalten konnte, kulminiert in der abschließenden Überzeugung Witolds, in der er in Lenas angeblicher Scham Bestätigung für seine Hirngespinste finde. Der Gebrauch der Bezeichnung ,Hirngespinste“ würde normalerweise davon zeugen, dass der Erzähler aus dem Gestammel der Assoziationen aufgewacht wäre und seine Lage bereits erkannt hat. Da die Zuschreibung der Scham Lena dicht, aber kaum nachvollziehbar mit anderen tobenden Elementen verflochten ist, scheint der Assoziationsamok Witolds noch kein Ende gefunden zu haben. Der kommentierende Erzähler kann anscheinend den intensiv manisch Erlebenden nicht abschütteln, von einem korrigierenden Kommentar kann daher diesmal keine Rede sein. Die geistige Lage des Erzählers bleibt nach dem Exzess mit der Katze unklar.

Zu Recht bemerkt Wilkiewicz, dass der Akt des Aufhängens der Katze „die Bedeutung des Motivstrangs ,Hängen“ [hervorhebe - K.S.] [...], da der Leser den Nexus Sperling-HolzspanKatze nachvollzieht.“" ${ }^{527}$ Gleichzeitig behauptet Wilkiewicz, dass durch die Tatsache, dass „,der Erzähler vom Indizien suchenden ,Detektiv` selbst zum Täter [wird - K.S.], die oben angeführte Sequenz [...] durch den Eingriff des handelnden Erzählers eine Abschwächung ‘528 erfahre. Diese Behauptung lässt sich meines Erachtens jedoch nicht bestätigen, an die fixierte

\footnotetext{
${ }^{526}$ Ich gehe davon aus, dass die metanarrativen Kommentare Witolds gewollt einen hohen Grad an nüchterner Präzision aufweisen, um in dieser Form mit den oft chaotisch registrierten Erlebnissen des Erzählers kontrastieren zu können.

${ }^{527}$ Zbigniew Wilkiewicz, a.a.O., S. 24.

${ }^{528}$ Ebd.
} 
Sequenz mag zwar in bestimmten Passagen in Kosmos seltener erinnert werden, von ihrer Abschwächung kann jedoch keine Rede sein.

In seinen Analysen des Romans erklärt Jerzy Jarzębski die Unsicherheit des Rezipienten angesichts der Tatsache, dass er gleichzeitig an drei Orten situiert ist: „'Bei Vorkommnissen“, die als sich ereignete hier und jetzt evoziert werden, ,bei dem Bewusstsein des Erzählers', das auf die Schnelle das Chaos der Erscheinungen ordnet, und, am Text ${ }^{\star}$ - weil der Erzähler durch das Nachahmen des Stils der gesprochenen Relation, den Adressaten ,nah an sich“ situiert. “529 So positioniert, kann der Leser nicht sicher sein, womit er gerade zu tun hat, mit den Ereignissen, den psychischen Operationen oder dem Erzählen selbst, der Roman macht somit den Eindruck, als ob er noch seinen Grundton, seine Leitmelodie nicht bestimmt hat ${ }^{530}$, als ob er die ziemlich schwammige Konturierung seiner Form nicht schärfen könnte.

„Weshalb ist man den Assoziationen auf Gedeih und Verderb ausgeliefert?“ (K, 92) fragt sich Witold rhetorisch irgendwie am Rande des Geschehens und muss damit bei dem Leser den Eindruck wecken, er habe sich bereits von der ,mentalen Schwäche` erholt. Sein einsamer Besuch beim Spatzen, der mittlerweile zu einer vertrockneten Kugel wurde, gewinnt für ihn jedoch eine Bedeutung, die außerhalb des Irrsinns nur sehr schwer nachvollziehbar wäre: „Eins ist sicher, wenn ich nun hierhergekommen bin und ihm meine Erhängung des Katers gebracht habe, so ist das keineswegs eine Bagatelle, sondern eine Tat, die ich an mir vollbracht habe, Amen. Amen. Amen.“ (K, 93) Der Wahnsinn des im Dickicht kontemplierenden Witolds kulminiert in den letzten im Gebüsch mit sich selbst gewechselten Worten: „Gehn wir schon. Wie gut, dass du dein Aufhängen des Katers mit dem Aufhängen des Spatzen verbunden hast, jetzt sieht das schon ganz anders aus. Wieso anders? Frag nicht.“531 (K, 94) Die geistige Verwirrtheit des Erzählers, um die sich der Leser spätestens ab jetzt ernste Sorgen machen müsste, entzieht sich jedoch einer klaren Diagnostizierung. Der Grund dafür ist einerseits die große Zahl der Besinnungs- und Scharfsinnsmomente, in denen Witold seine mentale Lage im Griff zu haben scheint, andererseits hat der Ausflug in die Berge durch seine detaillierte Beschreibung die Dynamik des Aufeinander-Verweisens ein

\footnotetext{
${ }^{529}$ Jerzy Jarzębski, Gra w Gombrowicza w Gombrowicza [Das Spiel Gombrowicz], Warszawa 1982, S. 480. [„Przy zdarzeniach”, które ewokowane są jako zachodzące tu i teraz, „przy świadomości narratora”, porządkującej na poczekaniu chaos zjawisk, i „przy tekście” - bo narrator naśladując styl relacji mówionej, lokuje adresata „tuż koło siebie."]

${ }^{530}$ Vgl. ebd., S. 480f.

${ }^{531}$ Wilkiewicz interpretiert diese Textstelle wie folgt: „Der innere Dialog kommt einer Selbstbestätigung gleich und gibt dem Erzähler das Gefühl, nicht nur auf der ,richtigen Fährte' zu sein, sondern durch die Verknüpfung der ,Hängungen' eine bedeutsame ,Wirklichkeit' evoziert zu haben. Zumindest für einen kurzen Augenblick fühlt er sich nicht im Chaos der inn umgebenden Welt verloren, sondern nimmt die Stellung eines Demiurgen ein." Zbigniew Wilkiewicz, a.a.O., S. 122.
} 
wenig verdünnt. Der Ausflug markiert m.E. eine Wende im Roman. Die Entfernung von der Pension, in der und in deren Umgebung so viel passierte, lässt Witold seine Erlebnisse ordnen. Für einen Moment setzt die Ruhe ein, nach der ihn aber gleich ,,irgendeine neue Kombination“ belagert, „entspann sich allmählich irgend etwas, verknüpfte sich ...“ $(K, 128)$ Im Hinterkopf Witolds formiert sich aber der Diskurs des Unheimlichen neu. Bald erfährt er eine Art Verfeinerung und Stärkung seines Potentials und zwar in der Entdeckung der Selbstigkeit. 


\subsubsection{Die verwirrende Unheimlichkeit der Selbstigkeit}

Das Exkursionsgeschehen führt allmählich in eine tiefere, ästhetisch ausgeklügelte Dimension der Unheimlichkeit ein. Im Gegensatz zu dem aus der Logik der Verdrängung und/oder des Wiederholungszwanges resultierenden Unheimlichen, wird die neue Unheimlichkeit mit einem Eindringen geboren, dem „Eindringen dessen da draußen, der ganzen Welt $[\ldots]^{\text {“ }}(\mathrm{K}, 85)$ Die Einweihung ins Wahrnehmen der neuen Dimension des Unheimlichen bedeutet eine wachsende Entfremdung der heimlichen Welt und führt durch die eigenartige Erfahrung der Selbstigkeit. Der polnische Neologismus wsobność, der ins Deutsche als Selbstigkeit ${ }^{532}$ übersetzt wurde, beinhaltet eine Reihe von Teilbedeutungen, die eine subtile, raffinierte, im Ästhetischen wahrnehmbare Eigenschaft einer Person darzustellen sucht: „Rückkehr nach innen, eigene Scheußlichkeit, eigener Dreck, eigene Verbrechen, Verschlossenheit, Angewiesensein auf sich selbst, ach, Selbstigkeit! Das Eigene!“6533 $(\mathrm{K}, 119)$ Es scheint unklar zu sein, warum die Selbstigkeit - >>gleich bei gleich im Himmelreich $<<^{534}$ (K, 126) - von Witold als widerlich wahrgenommen wird. Unbegreiflich bleibt auch der Mechanismus, der das Erscheinen und Erkennen der Selbstigkeit als solcher die Erinnerungen an die fixierte Kette von aufgehängten Objekten hervorzurufen erzwingt und diese Assoziation mit einer neuen Dynamik stärkt:

„[...] Selbstigkeit! Das Eigene! Und wie ein Blitz: Das muss zu dem Kater führen, der Kater ist ganz, ganz nah ... und schon kam mir der Kater raus, ich erfuhr den Kater. Ich erfuhr den begrabenen Kater, den erwürgten Kater - aufgehängt zwischen Spatz und Stäbchen, die dort regungslos waren und ihr Dasein wachsen ließen, die durch die eigene Regungslosigkeit am zurückgelassenen, verlassenen Ort stärker wurden. Teuflischer Trotz! Je weiter, desto näher! Je banaler und absurder, desto aufdringlicher und mächtiger! Was für eine Falle, was für eine höllisch boshafte Vorrichtung! Was für ein Hinterhalt!“ (K, 119f)

Die blitzartige und laute - gemessen an der Zahl der Ausrufezeichen - Explosion von Assoziationen und Ahnungen lässt den Leser vermuten, dass sich mit der Entdeckung der Selbstigkeit eine Sphäre aufgetan hat, die ein tieferes, bzw. irrsinnigeres Wahrnehmen des unheimlichen Geschehens ermöglicht. Das zweite, viel ruhigere Erscheinen der Selbstigkeit

\footnotetext{
532 In Indizien, der ersten Übersetzung von Kosmos wurde ,wsobność' mit ,Insichsein' u. ,In-sich-Sein' übersetzt. Vgl. Witold Gombrowicz, Indizien, Pfullingen 1966, S. 123 u. 130.

${ }^{533}$ An dieser Textstelle lassen sich sehr gut Schwierigkeiten der Kosmos-Übersetzer zeigen. In der Tielschen Übersetzung heißt es: „Umkehr nach innen, eigene Schrecklichkeit, eigener Schmutz, eigene Verbrechen, Eingeschlossenheit in sich selbst, Verurteiltsein auf sich selber, ach, Insichsein! Das Seine!“ Ebd. S. 123.

${ }^{534}$ Wörtlich übersetzt heißt es: „der Seine um das Seine zu dem Seinen“ [„swój do swego po swoje“] Für solche Übersetzung entschied sich auch Tiel in Indizien. Ebd., S. 130.
} 
bekräftigt noch ihr strategisches erstes Erscheinen, indem der seltsame Mechanismus zu einem bewussten Schritt zur Lösung des Rätsels führen sollte:

„[...] hätte diese widerliche $>$ Selbstigkeit $<<[\ldots]$ auch wohl irgendeine Neigung zu ihm [Leon, Lenas Vater - K.S.]. Was konnte es mir schaden, jetzt den Spatzen und all diese Befremdlichkeit dort in dem Haus anzusprechen. Ihm das anlegen und mal sehen, ob ich nicht etwas zu sehen bekäme, ich war doch wie eine Wahrsagerin, die in die Glaskugel, in den Rauch starrt.“(K, 126)

Sollte etwa Selbstigkeit zum Schlüssel, zum Geheimnis der Hängungen werden? ${ }^{535}$ Witold ahnt, dass er in der fremden Selbstigkeit seine Selbstigkeit wie im Spiegel betrachten konnte. Trotzdem geht er mit diesen Analogien sehr vorsichtig um. Die Erfahrung der Selbstigkeit war für ihn meines Erachtens eine unheimliche Erfahrung, die man eher verdrängen als beibehalten möchte. In seiner Analyse der Gombrowiczschen Pornographie beschreibt Markowski Fryderyk, den Protagonisten, als jemanden, der unberechenbar ist, weil er nichts Konkretes ist und dadurch alles sein kann. ${ }^{536}$ Markowski schreibt Fryderyk die Selbstigkeit zu, die sich in dem intensiven Sein dieser Figur äußert. Ähnlich verhält es sich m. E. mit der Selbstigkeit der Figuren in Kosmos. Diese Eigenschaft ist irritierend und beunruhigend zugleich und besitzt somit einen Hauch des Unheimlichen. Für den Leser bleibt es aber unklar, aufgrund welcher Logik das spezifische In-sich-Sein einiger Figuren die Erinnerung an die hängenden Fakten hervorruft.

Der Versuch, Leon mit dem Kater und der hängenden Serie zu konfrontieren, scheitert. Allmählich gewinnt Lenas Vater das - zunächst ihm gegenüber ambivalent gekennzeichnete Interesse Witolds, aber seine Pläne sind ganz andere als die des Erzählers. Die Intensität Leonscher Benehmensart scheint mit jedem seiner Worte ${ }^{537}$, mit jeder seiner clownesken

\footnotetext{
535, ,[...] aber Moment, vergessen wir andererseits [...] diese >>Selbstigkeit<<, dieses >>gleich bei gleich im Himmelreich $<<$ nicht, sollte darin der Schlüssel zum Rätsel liegen, der Schlüssel zu dem, was hier angerührt und ausgeheckt wurde, och, dieses >>gleich bei gleich $<<$ war wie eine Woge, die von ihm und dem Priester und den Tolos her anstieg - und etwas furchtbar Quälendes war daran - und dieses Etwas kam auf mich zu wie ein Wald [...]" (K, 140) Das leidige, widerliche Insichsein erkannte Witold bei drei Romanfiguren: bei Jadeczka, einer frisch vermählten Freundin Lenas, bei dem auf dem Weg in die Berge getroffenen Priester und bei Leon. Alle drei Figuren verrieten ihre Selbstigkeit durch die sich in ihrem Verhalten manifestierenden Symptome: „Er saß steif da mit ausgestreckten Hand und sah $>>$ sich $<<$ die Hand an - wie der Priester, der $>>$ sich $<<$ wurstelnd mit den Fingern beschäftigte, wie Jadeczka, die $>>$ sich $<$ ihrer Liebe hingab ... und ... und ... und ich, der ich $>>$ mir $<<$ verdorben hatte ..." (K, 131f) Verdorben hatte sich Witold Lena, indem er sie mit Katasias verdorbener Lippe assoziiert hatte.

${ }^{536}$ Vgl. Michał Paweł Markowski, a.a.O., S. 90.

537 „In wiederkehrenden Variationen ergötzt sich Leon an verblüffenden Wortspielen, die nicht, wie Witold zu Beginn noch vermutet, Ausdruck einer launischen Schrulle sind. Sie werden von Leon in einer Unterhaltung mit Witold ausdrücklich als Elemente einer bewusst praktizierten Redeweise legitimiert." Alfred Gall, Performativer Humanismus. Die Auseinandersetzung mit Philosophie in der literarischen Praxis von Witold Gombrowicz,
} 
Gesten zuzunehmen. Am Anfang nähert sich der Erzähler Leon sehr vorsichtig, er möchte ihn zwar in seine Geschichte hineinmontieren, gleichzeitig sieht er aber in genau diesem Akt eine Gefahr lauern. Reflektiert wird die Figur Leon somit zunächst aus einer sicheren metanarrativen Perspektive:

„Mir war eigentlich nur an einem gelegen: dass er mir nicht verrückt wurde. Denn es stand zu befürchten, dass er ein Wahnsinniger war, mente captus, und in diesem Falle würde er einfach bedeutungslos, er und alle seine eventuellen Taten und alle Geständnisse, und dann mochte sich herausstellen, dass auch meine Geschichte sich auf die anspruchslosen Torheiten eines armen Idioten stützte - und belanglos war.“ $(\mathrm{K}, 129)$

Ein geschickter ästhetischer Griff Witolds sollte Leon jedoch als harmlos und nützlich erscheinen lassen:

„Aber wenn ich ihn ins Schweinische stieß - och, dort konnte ich ihn gebrauchen, dort kam er mir vielleicht irgendwie mit Jadeczka, mit dem Priester, mit meinem Kater, mit Katasia in Verbindung ... dort konnte er nützlich sein, als ein weiterer bescheidener Ziegel meines Hauses, das eifrig an den Grenzen erbaut wurde.“ (K, 129f)

Glaubte der Erzähler wirklich an den Erfolg seiner Geschichte dank der strategischen Nutzung der metanarrativen Perspektive, so müsste er kurz nach ihrem Verlassen ein totales Fiasko dieser Strategie zugeben. Leon weiß sich der narrativen Absichten Witolds geschickt zu entziehen, er ist die einzige Figur im Roman, „die sich alleine enthüllt und ihre Gründe erklärt; die einzige, die für ihr Spiel Witold als einen unterworfenen Partner engagiert, und den sie dabei vom Außen wahrnimmt. “538 Die Besonderheit Leons beruht vor allem darauf, dass seine Art einen Spalt in der Narration ${ }^{539}$ auftut, , [...] dieser, der bis jetzt aufspürte, ergründete und urteilte wird von einem anderen erkannt und in die Komplizenschaft

Dresden 2007, S. 368f. Da die Sprachkreationen Leons ins Deutsche kaum übertragbar sind, verzichte ich auf ihre Analyse. Untersucht werden nur Teile des ,Berg-Dialogs', der eine der möglichen Schlüsselszenen für die Untersuchung der Sinnbildung in Kosmos liefert.

${ }^{538}$ Aleksandra Okopień-Sławińska, Wielkie bergowanie, czyli hipoteza jedności 'Kosmosu' [Das große Grebebsen oder die Hypothese der Einheit von 'Kosmos'], in: Zdzisław Łapiński (Hg.), Gombrowicz i krytycy [Gombrowicz und Kritiker], Kraków Wrocław 1984, S. 696. [„sama się odsłania i tłumaczy swoje racje; jedyną, która do własnej gry angażuje Witolda jako podporządkowanego partnera, a przy tym spogląda nań z zewnątrz."]

${ }^{539}$ Diesen Spalt, Bruch oder Störung verknüpfe ich mit der Interpretation von Anna Czabanowska-Wróbel, deren Meinung nach, Leon dem Erzähler entgegengestellt wird, dem er das Sprechen entziehen will. Leon sollte somit einen separaten Ort des Sprechens einrichten, der den Ort des Erzählens bedrohen wird. Vgl. Anna Czabanowska-Wróbel, Kosmos powtórzeń Witolda Gombrowicza [Der Kosmos der Wiederholungen Witold Gombrowicz'] In: Jerzy Jarzębski (Red.) Witold Gombrowicz. Nasz współczesny. [Witold Gombrowicz. Unser Zeitgenosse], Kraków 2010, S. 451. 
gezogen. ${ }^{6540}$ Ich würde behaupten, dass er diese Eigenartigkeit seiner intensiven Selbstigkeit verdankt.

In der Schlüsselszene des Ausflugs - im Berg-Dialog - erfährt Witold das Geheimnis des nicht selten clownesk anmutenden Verhaltens ${ }^{541}$ Leons sowie das wahre Motiv für die von Leon eingefädelte Exkursion:

„,>Der Witz ist eben<<, erklärte er sachlich, >>dass der arme Leon Wojtys in seinem grauen Leben nur einen, ich möchte sagen absoluten, Spaß gehabt hat ... und das war vor siebenundzwanzig Jahren mit dieser Köchin, aus dieser Berghütte. [...] Ein Jahrestag. [...] Eine Wallfahrt. Meine Frau, das Kind, der Schwiegersohn, der Priester, die Lottens, die Tolos, allesamt auf einer Wallfahrt zu meiner Lust [...] Sollen sie teilnehmen! [...] ha, ha, die wissen nichts! Sie wissen. $\ll(K, 138 \mathrm{f})$

Als vertrauenswürdig erkannt und durch eine gewisse Affinität zu Lenas Vater gekennzeichnet, darf Witold desweiteren in Leons Kommunikationsart eingeweiht werden. Der Kern des Leonschen sprachlichen Treibens bildet das im Polnischen nicht existierende Wort berg $^{542}$. Wie Olaf Kühl zu Recht bemerkt, „Solange das Wort ,berg' im sprachlichen Alleinbesitz Leons ist, bleibt es Zeichen einer Privatsprache, die nicht einmal den Anschein von Verständlichkeit erhebt [...] Bedeutung entsteht hier allein durch die semantisierende Wirkung der syntaktischen Konstruktion“ 543 In dem Schlüsselsatz „Bembergowanie bembergiem w berg!“‘ $(K, 148)$ [„Mit dem Greb in den Grebs grebebsen!“ (K, 182)] kann diesem Syntagma „qua Analogiebildung doch so etwas wie eine vage Bedeutung aufgeprägt [werden - K.S.], die sich aus einzelnen syntaktischen und semantischen Komponenten aufbaut. ${ }^{\text {"544 }}$ Da die Leonschen Wortkreationen in dem eindeutig erotischen Kontext entstehen, darf das ,mit dem Greb in den Grebs grebebsen` mit dem Geschlechtsakt assoziiert werden,

\footnotetext{
${ }^{540}$ Ebd., S. 696. [„(...) ten, który dotąd tropił, dociekał i osądzał, zostaje przez kogoś innego rozpoznany $\mathrm{i}$ wciągnięty do współdziałania."]

${ }^{541}$ Da sich die Textausschnitte zur Lebensphilosophie Leons über mehrere Seiten erstrecken, muss hier auf das Zitieren der entsprechenden Stellen verzichtet werden. (Vgl. K, 134ff) Auf den Punkt gebracht, klänge seine Maxime, „dass man sich am Kleinen ergötzen soll.“ Alfred Gall, a.a.O., S. 371. In der Zusammenfassung Leons heißt es: „Wenn man nicht hat, was man liebt, so liebt man, was man hat.“ (K, 136)

${ }^{542}$ In Indizien hat Tiel das Wort berg ohne Änderung übernommen. Da es aber im Deutschen tatsächlich das Wort Berg existiert, wird sich der deutschsprachige Leser dabei tatsächlich einen Berg vorstellen wollen, was zweifelsohne irreführend wäre. Kühl übersetz berg mit Greb.

${ }^{543}$ Olaf Kühl, Stilistik einer Verdrängung. Zur Person von Witold Gombrowicz, Berlin 1995, S. 88.

${ }^{544}$ Ebd. „Zwar hat in der obigen Konstruktion kein Wort außer der Präposition „w“ [,in' - K.S.] (wenn man sie als lexematische versteht) eine lexikalisierte Bedeutung; jedoch verleihen die grammatischen Suffixe und Endungen (Verbalsubstantiv „-ow-anie“, die Instr.Sg. -Endung „-i-em“ dem Ganzen eine bestimmte semantische Struktur. Als semantische Invariante der Konstruktion „bembergowanie bembergiem w berg“, unabhängig von der Bedeutung der einzelnen Lexeme, könnte man die Penetration verstehen (wenn man das Syntagma räumlich konkret und nicht metaphorisch deutet).“
} 
„und die einzelnen Satzteile werden rückwirkend durch ihre syntaktische Struktur ,semantisiert': ,berg' wäre dann etwa weibliches, ,bemberg' männliches Genital.“ ${ }^{545}$ Das Zelebrieren des Grebs nach Leonscher Art könnte aber viel mehr bedeuten als nur ein Versteckspiel, in dem der alte Wojtys unter dem Mäntelchen der lallenden Neologismen seine erotischen Phantasien zu entfalten sucht. Aleksandra Okopień-Sławińska entdeckt z.B. in ihrer detaillierten Analyse des ,berg'-Phänomens seine mögliche religiöse Bedeutung, indem sie schlussfolgert, dass das Greb-Zelebrieren sowohl den sakralen als auch den gottlosen Charakter hat, dass „es ein sündhaftes Begehren des Sakralen und eine gotteslästerliche Anmaßung eines religiösen Brauchs, mit dem es sich habgierig identifiziert“ ${ }^{\star 546}$ sei. Dem Grebebsen scheint eine raffinierte Dialektik zugrunde zu liegen, es erschöpft sich nicht im Tabu- oder Normbruch, es vollzieht sich eher in der subtilen Provokation, an der Grenze der Scham, es genießt die Unwissenheit der im Grebsritual Teilnehmenden. Seine Natur ist permanent durch Zweideutigkeiten stigmatisiert. ${ }^{547}$ Dieses von Okopień-Sławińska einleuchtend untersuchte Grebebsen, indem seine subtil konstruierte Ambivalenz enthüllt wird, gibt uns einen wertvollen Hinweis auf das in der seltsamen Praxis lauernde Desorientierungspotential.

Das rätselhafte Ritual des Grebebsens wird zunächst von Witold als widerlich und abstoßend empfunden. ${ }^{548}$ Es mag deswegen verwundern, dass der Erzähler seine so lange gepflegte Beobachterdistanz so schnell aufgibt. Hat er etwa geglaubt, dass ihm Leons Einsicht hilft, das Geheimnis der auf sich beziehenden hängenden Fakten und der sich assoziierenden Münder zu enthüllen? Im Gegensatz zu Witold und Fuks lässt sich Leon jedoch „,nicht auf eine nach außen gerichtete Sinnsuche ein “549, seine konsequente Selbstigkeit konnte also den Erzähler-Detektiv erkenntnismäßig nicht weiter bringen. Werden also Leons Grebebsen und die Erfahrung der Selbstigkeit zur nächsten narrativen Sackgasse? Der Erzähler, sei es mit vollem Bewusstsein oder aus eigener Verwirrtheit, macht es dem Leser nicht leicht. Ein angespanntes Erwarten beherrscht Witold angesichts der nähernden Zeremonie, der Wechsel der Zauberformel mit Leon verleiht der Beziehung der beiden den Eindruck eines Komplotts:

\footnotetext{
${ }^{545}$ Ebd. Kühl erklärt somit als wenig überzeugend die Interpretation von Ewa Thompson, die das Grebebsen mit Masturbation assoziiert: „,,bembergowanie bembergiem w berg' and further derivatives from the root berg which does not exist in Polish, are childlike descriptions of masturbation." Vgl. Ewa Thompson, Witold Gombrowicz, Twayne 1979, zit. nach Olaf Kühl, a.a.O., S. 88.

${ }^{546}$ Aleksandra Okopień-Sławińska, a.a.O., S. 701 [„(...)jest grzesznym pożądaniem świętości i bluźnierczym przywłaszczaniem obrządku religijnego, z którym zachłannie się identyfikuje."]

${ }^{547}$ Vgl. ebd., S. 701.

${ }^{548}$ Leon wird von Witold als Schwein, Schmutzfink, Lustmolch und Onanist beschimpft. Vgl. K, $129 f$.

${ }^{549}$ Alfred Gall, a.a.O., S. 368.
} 
„Hätte er nur $>$ Greb $<<$ gesagt, es wäre nicht der Rede wert gewesen. Aber ich hatte auch > Greb $<$ gesagt. Und mein Greb in Verbindung mit seinem (vertraulichen, privaten) Greb förderte seinen Greb aus der Vertraulichkeit zutage. Das war nun nicht mehr das private Wörtchen eines Sonderlings. Das war jetzt etwas wirklich ... das war etwas Existierendes! Vor uns, hier! Und auf einmal schoss es darüber hinaus, stieß hinein, unterwarf ...“ $(K, 164)$

Ein nächstes nicht gehaltenes Versprechen der Offenbarung, ein trickreich entfachter, scheinbarer Drang nach Sinn, hängende Fakten ,zusammen mit den Mündern ... wie Abfall im brodelnden Kessel eines Wasserfalls - untergehend“ (K, 164), bleiben dem verblüfften Leser als Bilanz der Grebebsenepisode. In seiner Selbstbezüglichkeit bleibt Leon ein Minimalist, ein Meister der kleinen, unscheinbaren Annehmlichkeiten, seine minimalistisch konzipierte Sprache „erschöpft sich in der Funktion des sexuellen Begehrens“ ${ }^{6550}$ und kann daher keinen Beitrag für erzählerische Ermittlungen leisten. Deutlich spürbar wirkt dann aber die Spuren- und Reizüberflutung, denn ,ausdehnen ließ sich das auch nicht mehr $[\ldots]^{“(}(\mathrm{K}$, 167) „Die Zerstreutheit im Wirbel der inkommensurablen Perzeptionsmomente verführt zur allseitigen Umschau nach neuen Zeichen, die sich mit den beiden bereits aufgebauten Reihen verknüpfen lassen. “551 Nach neuen Reizen Ausschau haltend wird Witold schnell fündig: „Ein hängender Mensch [...] Ludwik, an einem Gürtel hängend [...] hing diese TATSACHE, eine hängende Tatsache $[\ldots]^{\text {“ }}(\mathrm{K}, 168 \mathrm{f})$. Der kurz anhaltenden Verblüffung folgt die erneute Evokation der hängenden Objekte, der hängende Ludwik scheint die Reihe ordnungsgemä $\beta$ zu vervollständigen:

„Der Spatz gehängt, das Stäbchen hängend, der Kater erwürgt-gehängt, Ludwik aufgehängt. Wie hübsch das passte! Welch eine Konsequenz! Die idiotische Leiche wurde zu einer logischen Leiche - nur dass die Logik auch schwer war ... und zu sehr meine ... persönliche ... so eine besondere ... private.“ $(\mathrm{K}, 169 \mathrm{f})$

Angesichts der Wahrnehmung der schweren hängenden Tatsache im Grübeln versenkt, erkundet Witold die Fülle möglicher Kombinationen. Eine Ahnung macht sich spürbar, ein Verlangen nach Ergänzung, nach einem Zug, der zwei Ideen, zwei Ordnungen verbinden möchte. Der Protagonist nähert sich vorsichtig der Leiche, dreht Ludwiks Kopf zum Mond und steckt den Finger in seinen Mund. „Der immanenten Folgerichtigkeit einer im wahrsten

\footnotetext{
${ }^{550}$ German Ritz, Kosmos albo strach przed Pałubq. Metafikcyjna lektura ostatniej powieści Gombrowicza [Kosmos oder die Angst vor Pałuba. Metafiktionale Lektüre des letzten Romans Gombrowicz'], in: Marek Zybura (Hg.), ,Patagończyk w Berlinie' Witold Gombrowicz w oczach krytyki niemieckiej ['Ein Patagonier in Berlin' Witold Gombrowicz in den Augen der deutschen Kritik], Kraków 2004, S. 524. Ritz sieht in den Figuren Leons und Fuks' Doppelgänger Witolds. Die wechselnden Konstellationen der Doppelgänger dynamisieren aber auch verdunkeln das Sich-aufeinander-Beziehen der Figuren Vgl. dazu: ebd., S. $521 \mathrm{ff}$.

${ }^{551}$ Alfred Gall, a.a.O., S. 355.
} 
Wortsinne >>verrückten $<$ Logik gehorchend zeigt sich Witold befriedigt über die endlich mögliche Verknüpfung der Münder mit dem Hängen.““552 Nach der gelungenen „Integration der beiden Wahrnehmungsreihen zu einem Verweisungszusammenhang“ ${ }^{553}$ scheint sich endlich, obwohl irgendwie beiläufig, ein Gedanke herauszukristallisieren; im Sinne einer Lösung detektivischer Ermittlungen konstatiert Witold: „Ich war ein Hängen.“ (K, 175) Wie ist es aber zu verstehen, wenn der Erzähler selbst die Reihe der hängenden Objekte nur um den Kater erweitert hat? Eine originelle und - wie der Literaturwissenschaftler selbst behauptet - einzig sinnvolle Aufklärung der rätselhaften Konstatierung, finden wir bei Markowski, der über den hängenden Ludwik reflektierend zu dem Fazit kommt, dass ihn nur der Diskurs über das Hängen erhängen konnte: „Es würde bedeuten, dass wir es in Kosmos mit solchem performativen Niveau der Narration zu tun haben, das dem Erzähler entwischend, die schaffende Kraft in der Ereignisfolge besitzt. Witold weiß gar nicht, dass er indem er über das Hängen spricht, zugleich Ludwik erhängt.“ 554 Die hängende Ludwikstatsache, egal wie erschütternd und absurd sie erscheinen mag, bildet jedoch meines Erachtens keinen Höhepunkt des Romans. ${ }^{555}$ Die Bedeutung der hängenden Leiche erschöpft sich darin, dass ihr ein Platz in der Serie der hängenden Objekte eingeräumt wird, und dass die Serie dadurch eine weitere Stärkung erfährt. Anders verhält es sich mit der Geste des Fingersteckens in den toten Mund. Dieser Zug liefert eine neue ästhetische Erkenntnis, d.h. eine erzwungene Verknüpfung zweier inkompatibler Assoziationsreihen, sein Durchführen kann jedoch nicht als bahnbrechend qualifiziert werden. Witolds erneutes Fingerstecken in den, diesmal lebendigen, Mund des Priesters und die Absicht, Lena zu erwürgen und zu

\footnotetext{
${ }^{552}$ Ebd., S. 381. „Und dabei eine tiefe Befriedigung, dass endlich der $>>$ Mund $<<$ sich mit dem $>$ Hängen $<<$ verbunden hatte. Ich hatte sie verbunden! Endlich. Als hätte ich meine Pflicht getan." (K, 175) Der aufmerksame Leser müsste, wie verschwommen auch immer, sich daran erinnern können, dass der Gedanke an die Verknüpfung der beiden Wahrnehmungsreihen bereits von Witold geäußert wurde: „Denn (versuchte ich die Scharade zu lesen) es besteht ja kein Zweifel [...], dass ich selbst das Geheimnis der Mund-LippenVerbindung war, es hatte sich in mir vollzogen, ich und niemand anders hatte diese Verbindung erschaffen aber (Achtung!) indem ich den Kater aufgehängt hatte, war ich [...] in jene Gruppe von Spatz und Stäbchen eingetreten, ich gehörte demnach beiden Gruppen an - folgte daraus nicht, dass die Verbindung von Lena und Katasia mit dem Spatzen und dem Stäbchen nur durch mich stattfinden konnte? - und hatte ich dadurch, dass ich den Kater aufgehängt hatte, nicht tatsächlich eine Brücke festgelegt, die alles verband ..." (K, 108) Da es schon hier dem Erzähler die Möglichkeit dämmerte, dass er selbst der Kreator des rätselhaften Auf-sichBeziehens sein könnte, würde ich dieser Stelle eine größere Bedeutung zuschreiben.

553 Ebd., S. 381.

${ }^{554}$ Michał Paweł Markowski, a.a.O., S. 179, Fn. 153. [„,To by oznaczało, że w Kosmosie mamy do czynienia z takim performatywnym poziomem narracji, który wymykając się narratorowi, ma siłę sprawczą w porządku zdarzeń. Witold bowiem nie wie wcale, że mówiąc o wieszaniu, wiesza Ludwika."]

${ }^{555}$ Anders sieht es aber Wilkiewicz: „Durch den unerwarteten Höhepunkt des Romans (Selbstmord Ludwiks) wird das Gesamtmotiv noch einmal aktualisiert und gibt dem Roman eine analoge, keineswegs logische oder gar kausale Sinnstruktur, aus der die metaphysische Gesamtaussage resultiert, da der suggerierte Zusammenhang vom Leser kognitiv nicht nachvollzogen werden kann.", Zbigniew Wilkiewicz, a.a.O., S. 25.
} 
erhängen, sind für mich Ausdruck der geistigen Lage des Protagonisten, der keinen Fortschritt erzielte. Der Roman ,franst gegen Ende zusehends in eine lose Aneinanderreihung einzelner Aufzeichnungen aus. “556 Auf der letzten Seite verschwinden sogar die Kommata, als ob der Erzähler in letzter Verzweiflung angesichts des sich ausbreitenden Chaos, die ihn überflutenden Assoziationen in aller Eile von sich wegzuspülen sucht. „In einer Wortkaskade [...] klingt $>>\operatorname{Kosmos}<<$ aus. “657

Hat der Leser den Roman zu Ende gelesen, wird er sich des Eindrucks nicht erwehren können, dass Kosmos ein über 150 Seiten gespielter Streich ist, der ihm seitens des Erzählers angetan wurde. Das naive, aufmerksame Verfolgen von Witolds Ermittlungen, die Sensibilisierung in der Erwartung der Hervorbringung irgendeiner Sinnhaftigkeit aus dem keimenden Embryo irgendeines Ganzen, musste den Leser zum dem Punkt bringen, an dem die ganze Geschichte nur noch als ein wahnhafter Exzess erscheinen konnte. Kosmos ist meines Erachtens tatsächlich ein Streich, aber was für einer! Der Roman ist in meiner Überzeugung extrem gekonnt konstruiert im Hinblick auf das ästhetische Raffinement und die Komplexität, die er im Verursachen der leserlichen Verwirrung zu entfalten weiß. Kosmos ist leider keine sichere Erkenntnis, keinerlei fixierbare Einsicht und keine klare Bedeutung zu entnehmen. Das ,Prinzip des Hängens“, die Selbstigkeit oder das ständige ,Eindringen dessen da draußen', bilden unlösbare Desorientierungsknoten, die das Herauskristallisieren eines Einzelsinns konsequent verhindern. Hinter jedem Versuch, die Bedeutung Kosmos ‘ aufzuspüren und zu fixieren lauert die Falle der Allsinnhaftigkeit, die jede denkbare Kombination legitimiert und somit der paranoiden Realitätswahrnehmung ähnelt. Die Forschung zu Gombrowicz scheint einerseits zu zeigen, dass die Untersuchung seiner Werke kein hoffnungsloses Unterfangen darstellen muss. Beschränken wir uns jedoch ausschließlich auf die Sichtung der Analysen von Kosmos, überrascht uns die Fülle unterschiedlicher, nicht selten widersprüchlicher Deutungen dieses Romans. Gombrowicz' intuitive Einschätzung zu seinem letzten Buch mag diesen Zustand teilweise prophezeit zu haben: , [...] mir scheint es, dass das Grausen von Kosmos entschlüsselt werden wird, aber wohl nicht so bald. ${ }^{\text {(558 }}{ }^{3}$ Was heißt aber „nicht so bald“? Sind wir nach einem halben Jahrhundert seit seinem Erscheinen ausreichend fortgeschritten, um behaupten zu können, Kosmos Entschlüsselung liege bereits vor? Bezeugen etwa all die mühsam herausgearbeiteten Deutungen dieses Romans, dass sein Rätsel gelöst wurde, und dass es eben auf seiner Vieldeutigkeit beruht? Oder bezeugt dieses

\footnotetext{
${ }^{556}$ Alfred Gall, a.a.O., S. 382.

${ }^{557}$ Ebd., S. 382. Mit der Rückkehr nach Hause, nach Warschau und der Information, dass es da zu Mittag Hühnerfrikassee gab, bricht Witold jeden Kontakt mit den hängenden Tatsachen ab. Vgl. K, 182.

${ }^{558}$ Witold Gombrowicz, Eine Art Testament, München Wein 1996, S. 129.
} 
Fazit eher das Gegenteil, d.h. die andauernde Unmöglichkeit einer plausiblen Interpretation? Um der Falle der bloßen Rhetorik zu entkommen, möchte ich - angesichts der postmodernen radikalen Pluralität - die Gombrowiczsche Prophezeihung zu Kosmos als ungültig erklären.

Da das Spekulieren darüber, ob Kosmos bereits und von wem überzeugender entschlüsselt wurde, keinen literaturwissenschaftlichen Nutzen hätte, und von einem Standpunkt aus durchgeführt werden müsste, den es in dieser Disziplin nicht mehr geben $\mathrm{kann}^{559}$, möchte ich das Werk erneut untersuchen, die Überzeugungskraft der bisher erbrachten Forschung überprüfen und diese mit neu gewonnenen Erkenntnissen vergleichen. Der zweite Anlauf nimmt strategisch an, man habe in der ersten Annäherung Spuren übersehen, deren Relevanz für die Konstituierung der Desorientierung gar nicht erkannt oder als marginal eingeschätzt wurden. Die erneute Ermittlung startet mit einer Blickverstellung, die die bisher unbelichteten Regionen zu durchforschen ermöglicht. Die hängende Serie, die Unheimlichkeit der Lippe, die Erfahrung der Selbstigkeit, das Auf-sich-Beziehen der Assoziationen und endlich das Leonsche Grebebsen wurden als Indizes für das Desorientierungspotential sorgfältig protokolliert und bilden die Grundpfeiler der strategischen Desorientierung.

${ }^{559}$ Da die heutige Literaturwissenschaft scheint m.E. Dissens mehr als Konsens zu schätzen . 


\subsection{Vom Erdklümpchen zum Regenguss - ein Laboratorium}

\section{des Bewusstseins}

„Das Bewusstsein hat etwas, das es zur Falle macht für sich selbst.“

W. Gombrowicz

Die Ankündigung der Lektüre Kosmos ' hört sich fast wie der Werbespot eines Reisebüros an:

„Was für Abenteuer, was für Eskapaden mit der Wirklichkeit, während sie sich so aus dem Nebel wälzt! Innere Logik und äußere Logik. Die Fallen der Logik. Irrwege des Geistes: Analogien, Oppositionen, Symmetrien... [...] Die Bildung von seitlichen Verzweigungen... dunklen Höhlen... Verstopfungen... Hemmungen, Strudeln... Drehungen...“560

Für mutige, herausforderungslustige Gemüter scheint das Eintauchen in diese unheimliche Welt alles andere als Langeweile zu versprechen. Da erst eine solide Terrainerkundung die ersten Orientierungspunkte in einer Welt voller überraschenden Wahrnehmungen sichern kann, sichten wir aufmerksam die anfängliche Darstellung des Schauplatzes: „[...] Erde, Wagenfurchen, Schollen, Funkeln von glasigen Steinchen, Gleißen, Hitze, summt, flimmernde Glut, es ist schwarz von der Sonne, Häuschen, Zäune, Felder, Wälder, dieser Weg, dieser Marsch [...]“ (K, 7) Im Grunde wäre es nichts Besonderes und dann wieder das Gleiche und mal wieder glänzte es ,,von Sonne, aber schwarz, Schwärze der Bäume, Grauheit der Erde, bodennahes Grün der Pflanzen, alles ziemlich schwarz.“ (K, 8) Aber warum schwarz? Es darf doch nicht wirklich schwarz sein. Unsicher erinnert man sich an dieses Eindringen, „Eindringen dessen da draußen, der ganzen Welt [... $]^{\text {“ }}(\mathrm{K}, 85)$ Kein Zweifel, meint Markowski, es ist „der schwarze Fluss des Kosmos', der die heimlichen Gestalten der Welt unterspült und der Sinn beginnt zu verdunsten. “561 Der die heimliche Welt unterlaufende Kosmos, ein graduell, punktuell verlaufender Prozess unzähliger Entgleisungen des Bekannten, mündet in eine ,ontologische Katastrophe“: „,...] der Sinn, den man bis jetzt als Beziehung zwischen den Bedeutungen definierte, wird mit dem Unsinn, d.h. mit dem Referenzmangel unternäht, die Menschen hören dabei auf, sich selbst und die anderen zu verstehen. ${ }^{\text {(562 }}$ Das Existieren in einer referenzlosen Welt wird aber unerträglich, um jeden Preis werden neue Beziehungen geknüpft, aus den Resten des gebliebenen neue Bedeutungen

\footnotetext{
${ }^{560}$ Witold Gombrowicz, Tagebuch 1953-1969, München Wien 1988, S. 911.

${ }^{561}$ Michał Paweł Markowski, Czarny nurt Gombrowicz, świat, literatura. [Die schwarze Strömung Gombrowicz, Welt, Literatur] Kraków 2004 S. 112. [„(...)czarna rzeka Kosmosu podmywa już znajome kształty świata i sens zaczyna się ulatniać."] In einem bereits von mir zitierten Kommentar Gombrowicz' zu Kosmos (Vgl. S. 125.), unterstreicht sein Autor die Schwärze seines letzten Romans als seine wichtigste ästhetische Eigenschaft.

${ }^{562}$ Ebd., S. 35. [„Sens, który definiował się do tej pory przez relację między znaczeniami, zostaje podszyty bezsensem, czyli brakiem referencji, ludzie zaś przestają rozumieć siebie i innych."]
} 
zusammengebastelt, ,jetzt jedoch, nach der ontologischen Katastrophe, in der alles von den klaren Bedeutungen abgespült wurde, wird sich der Sinn nur mühsam und irgendwie nicht direkt bilden, sondern [...] schräg, seitlich, von unten, mit Unsinn infiziert, parodiert, karikiert. ${ }^{\text {"563 }}$ Markowskis Fazit leuchtet ein, indem es meines Erachtens den dem Roman zugrunde liegenden imaginären Mechanismus der oszillierenden Konstituierung und den Zerfall der Wirklichkeit perfekt erkennt und beschreibt. Seine Behauptungen liefern eine der originellsten Deutungen Gombrowicz' Werke und fordern nicht selten die meist anerkannten Gombrowiczforscher heraus.

In den zahlreichen, in dem ganzen Text Kosmos ' verstreuten Momenten des, Eindringens dessen da draußen ${ }^{564}$, wird allmählich die Umwelt des Protagonisten der Heimlichkeit und Selbstverständlichkeit der Beziehungen beraubt und punktuell mit dem Unheimlichen unterlaufen. Aus den Resten der übriggebliebenen Bedeutungen, d.h. aus den Wahrnehmungsfetzen, die noch den Anschein der Sinnhaftigkeit zu besitzen scheinen, wurden aus eigener Invention, Intuition und/oder Obsessionen in Eile neue Bedeutungsreihen gebastelt, deren Beständigkeit und Legitimierung der Erzähler durch ständiges Wiederholen überprüft. Die Strategie der Repetition zeigt sich in Kosmos als enorm erfolgreich, wiederholtes Evozieren der verknüpften Wahrnehmungsreihen kreiert nämlich selbst einen Teil der Romanwirklichkeit - die nacheinanderfolgenden Hängungen. Das konsequente SichErinnern an bereits Erlebtes gewinnt somit die Kraft eines performativen Aktes.

Angesichts der schwindenden Selbstverständlichkeit der bisher vertrauten Relationen manipuliert Witold experimentierend an neuen Bedeutungen. Die Geste, mit der Witold seinen Finger in den Mund des toten Ludwiks steckt, ist ein gutes Beispiel einer Atmosphäre der enormen Unsicherheit, in der die Erkundung der neuen, unbekannten Wahrnehmungsdimension in Gang gesetzt wird. Diese Szene bildet auch meines Erachtens den unheimlichsten Moment des Romans. In der Freudschen Optik wäre es nicht verfehlt, diese seltsame Geste als Resultat der Wiederkehr des Verdrängten zu deuten. Verdrängt werden von Witold sowohl die Münder als auch das Hängen, beide als Hauptelemente einer Assoziationsreihe, deren Wahnhaft-Werden den Erzähler dazu veranlasst, seine Bemühungen

\footnotetext{
${ }^{563}$ Ebd., S. 36. [„Teraz jednak, po ontologicznej katastrofie, w której wszystko zostało obmyte z oczywistych znaczeń, sens będzie budował się opornie i jakby nie wprost, ale [...] ukośnie, bocznie, oddolnie, zarażony bezsensem, sparodiowany, skarykaturyzowany."]

${ }^{564}$ Es sind Passagen wie diese: „Anhäufung, Abgrund, Wirrwarr ... zuviel, zuviel, zuviel, Gedränge, Bewegung, Türmung, Vorstürzen, Schieben, ein allgemeines Durcheinander, große ausfüllende Mastodonte, die augenblicklich zu tausend Einzelheiten, Gruppen, Klumpen, Abenteuern zerfielen, in ungefügem Chaos, und plötzlich sammelten sich all diese Einzelheiten wieder in übermächtiger Gestalt! [...] ein Materiegewitter tobte." (K, 104f) Gemeinsam allen ähnlichen Momenten in Kosmos ist die lähmende Ratlosigkeit des Erzählers angesichts des plötzlichen Eindringens der aus unüberschaubarer Fülle der Elemente bestehender Wirklichkeit.
} 
um die Sinnhaftigkeit der Geschehnisse zu intensivieren. Die extreme Unheimlichkeit dieser Szene lässt sich aber noch besser durch Ergänzungen Bearns und Markowskis veranschaulichen. Der erste betont in Anlehnung an Wittgenstein die Plötzlichkeit, mit der das Gefühl der Unheimlichkeit zu Stande kommt und schreibt ihr die Qualität einer Offenbarung zu. ${ }^{565}$ Der zweite sieht das Unheimliche als „Resultat des Aus-dem-GewichtBringens der Welt der heimischen Vertrautheit. “ ${ }^{566}$ Beide Bemerkungen liefern eine plausible ergänzende Deutung dieser Szene. Durch das Stecken des Fingers in den Mund des Erhängten vollzog sich die symbolische Verbindung der Münder mit dem Hängen und zwar in der Art einer Offenbarung. Die vollzogene Verbindung als solche war jedoch Ausdruck einer irrsinnigen, von der vertrauten Logik entgleisten Idee, ein Eintreten in den Bereich einer ,privaten“ Logik. Die höhere Intensität der Unheimlichkeit in diesem Fall muss sich aus weiteren Eigenschaften des Schauplatzes ergeben, d.h. aus der Dämmerung, des Waldes und des Allein-Seins des Protagonisten während der Szene und vor allem der Wahrnehmung eines unnatürlichen Todes. Darüber hinaus weist selbst Witolds mentale Kondition eher unheimliche Züge auf. Bemerkenswert ist die Intensität der Wahrnehmungsverarbeitung, mit der Witold die hängende Leiche betrachtet. Die Entdeckung des Selbstmörders und seine Ausnutzung für die Vervollständigung der Verweise werden mit wilden Spekulationen eingeleitet und münden in eine ordentliche Reflexion über die vollbrachte Tat. Jeder frisch fixierten Assoziationskonstellation folgen intensive Maßnahmen des Sich-Versicherns, dass die geschaffenen Sinnstrukturen einen hohen Plausibilisierungsgrad besitzen. Der Prozess der Zurückgewinnung der Welt nach dem vernichtenden ,Eindringen dessen da draußen“ scheint also in Kosmos immer die gleiche Abfolge zu haben und er erschöpft sich im Konstruieren vorläufiger, provisorischer Bedeutungsgerüste.

Nicht ohne Grund stellt sich daher der Erzähler wiederholt die Frage - Was kann man wissen? Da er sich jedoch um ihre explizite Beantwortung nicht bemüht, sollte diese in der Luft hängende Frage den Leser vielleicht ein bisschen beunruhigen. Sie sollte meines Erachtens auch den Rezipienten dazu provozieren, sich selbst die gleiche Frage zu stellen. Bei dem Erzähler scheint dieses Dilemma in Anbetracht dessen, was oben schlussfolgert wurde, bereits ihre Lösung gefunden zu haben. Der Erzähler kann daher nur das wissen, was er sich aus den Resten des (einst vertrauten) Sinns und seiner assoziativ arbeitenden Wahrnehmung herauspräpariert. Der Leser kann zunächst in der Unwissenheit der epistemologischen Strategie des Protagonisten noch weniger wissen. Sein Weg zur Erkenntnis muss somit durch

\footnotetext{
${ }^{565}$ Vgl. Zit. 505, S. 140.

${ }^{566} \mathrm{Vgl}$. Zit. 489, S. 137.
} 
ein konsequentes kritisches In-Frage-Stellen der Plausibilität und der Überzeugungskraft der Witoldschen Denkweise und durch Lokalisieren der erzählerischen Sackgassen in der Bildung der Bedeutung führen. Es muss dabei aber der subtile Unterschied im Auge behalten werden, ob es sich um Fallen handelt, denen der Erzähler selbst nicht zu entkommen weiß, oder ob er den Leser in solche hineinzumanövrieren versucht. Die folgende Szene illustriert deutlich eine Bewusstseinsfalle, angesichts derer Witold in Ratlosigkeit gerät. Der der Perzeption dieses - ästhetisch ausgeklügelt konzipierten - Dilemmas zugrunde liegende Mechanismus soll dabei näher untersucht werden, dazu muss aber eine längere Passage aus Kosmos angeführt werden:

„Es war eine Falle aus nichts, eine dumme ... Vor mir tauchten zwei kleine Steine auf, einer rechts, der andere links, und ein bisschen weiter links schimmerte ein hellbrauner Fleck von Ameisen gelockerter Erde, noch weiter links befand sich eine ansehnliche Wurzel, schwarz und verfault - alles in einer Linie, in der Sonne verborgen, im Glanz getarnt, im Licht versteckt - ich wollte schon zwischen den Steinen hindurchgehen, bog aber im letzten Augenblick etwas ab, um zwischen dem Stein und der gelockerten Erde durchzugehen, das war eine minimale Abweichung, nicht der Rede wert, es ging so und so ... aber diese winzige Abweichung war doch unbegründet, und das, glaube ich, brachte mich aus der Fassung ... also änderte ich unwillkürlich erneut ein wenig die Richtung, um so vorbeizugehen, wie ich es anfangs gewollt hatte, zwischen den Steinen, doch da spürte ich eine gewisse Hemmung, och, eine minimale, die daher rührte, dass nach dem zweimaligen Abbiegen meine Absicht, zwischen den Steinen hindurchzugehen, schon den Charakter einer Entscheidung angenommen hatte, einer geringfügigen natürlich, denn die vollkommene Gleichgültigkeit dieser Dinge im Gras berechtigte zu keiner Entscheidung, was machte es für einen Unterschied, hier oder da vorbeizugehen [...] Ich beschloss daher, zwischen den Steinen hindurchzugehen ... doch in den paar Sekunden, die vergangen waren, war der Entschluss noch mehr Entschluss geworden und schien unmöglich, es war doch alles eins ... also hielt ich wieder inne. Und wütend setzte ich erneut das Bein vor, um zwischen Stein und Erde hindurchzugehen, wie es meine Absicht gewesen war, da sehe ich, dass es kein gewöhnlicher Durchgang mehr, sondern etwas Bedeutsameres wäre, wenn ich nach dreimaligem Start zwischen dem Stein und der Erde hindurchginge ... also wähle ich den Weg zwischen der Wurzel und der Erde ... merke aber, dass das so aussähe, als hätte ich Angst bekommen, und will erneut zwischen Stein und Erde hindurchgehen, zum Teufel, was geschieht hier, was ist los, ich werde hier doch nicht auf ebenem Wege stehen, was soll das, kämpfe ich denn mit Gespenstern, um Himmels willen! [...] Ich rührte mich nicht. Ich stand da. Doch mein Stehen wurde immer unzurechnungsfähiger, ja wahnsinniger, ich hatte kein Recht zu stehen, das war UNMÖGLICH, ICH MUSSTE GEHEN ... Aber ich stand da. Und da in dieser Unbeweglichkeit, wurde meine Unbeweglichkeit mit der Unbeweglichkeit des Spatzen dort im Gebüsch identisch, mit der Unbeweglichkeit des Systems, das dort unbeweglich verharrte, Spatz-Stäbchen-Kater, mit jenem leblosen unaufhörlichen System, wo Unbeweglichkeit sich staute, wie ich mich hier, auf der Wiese, in meiner wachsenden Unbeweglichkeit staute, ohne mich bewegen zu können ... Da setzte ich mich in Bewegung. 
Mit einem Male brachte ich alles in mir, alle Unmöglichkeit zu Fall und ging ganz glatt vorbei, ohne auch nur zu wissen, wo, denn das hatte keine Bedeutung $[\ldots]^{“}$ (K, 142f)

Die in der obigen Szene enthaltenen Dilemmata des Erzählers sowie die Auseinandersetzung mit ihnen, liefern meines Erachtens den wichtigsten, obwohl impliziten Beitrag zur Aufklärung der Sinnbildung im letzten Roman Gombrowicz‘ . Der Moment des Erstarrens auf ebenem Wege markiert das Ausschalten der äußeren, vertrauten Logik. Der einfachen Bewegung vorwärts steht auf einmal etwas im Wege, was normalerweise gar nicht wahrgenommen wäre. Witolds Perzipieren wechselt die Wahrnehmungsebene und schaltete die innere, private Logik ein. Die Sinnbildung startet und kreiert Bedeutungen und Beziehungen an Orten und aus Objekten, die bedeutungs- oder referenzlos sind. Die verdrängte äußere, d.i. die herkömmliche, vertraute Logik meldet sich inzwischen punktuell, indem sie ihre Maßstäbe zurückzugewinnen sucht ${ }^{567}$, kommt dann endlich verstärkt aus der Verdrängung zurück und annulliert im Augenblick die Impasse des verwirrten Bewusstseins. Die sich bekämpfenden Systeme der Sinnbildung dynamisieren stark die Apperzeption des Erzählers, somit ließe sich auch der ganze Kosmos im Sinne eines Prozesses untersuchen, den man als graduelle Privatisierung der Logik bezeichnen könnte. Jerzy Jarzębski deutet die zitierte Szene dagegen als Flucht Witolds vor dem (vollen) Bewusstsein. Der Protagonist hat Angst davor, zwischen den Dingen gefangen zu werden, er assoziiert daher jede zu treffende Wahl mit einer Art Gefangenschaft. ${ }^{568}$

Obwohl der angeführte Textausschnitt hauptsächlich Witolds Bewusstseinsperipetien thematisiert, erschöpft es sich nicht im ästhetischen Ausdruck dieses Problems. In den ersten Sätzen der Szene beschreibt der Protagonist mit großer Präzision die Struktur der Falle. Nachdem er ihre Bestandteile genannt hat, weist er auf die Situierung der die Falle bildenden Elemente hin: ,alles in einer Linie, in der Sonne verborgen, im Glanz getarnt, im Licht versteckt.“ $(K, 142)$ Der Erzähler konnte den Hinweis natürlich als provokativ oder einfach aus Jux so formuliert haben, ich behaupte jedoch, dass dieser Zug auf einen tieferen Sinn hindeute. Das Erscheinen der Dinge in der Sonne, im Glanz und Licht symbolisiert ihr Anden-Tag-Bringen, von dem Verborgen-, Getarnt- oder Versteckt-Sein kann daher keine Rede sein. Die Steine, die Wurzel und die gelockerte Erde sind aus dem heimlichen Zusammenhang gerissen und verlangen als solche, d.h. entgleiste, nach einem neuen Sinn, nach einer sinnvollen Verankerung. Die Bedeutungen werden sich sozusagen an der Oberfläche

\footnotetext{
${ }^{567}$ Das sich verlängernde Stehenbleiben erscheint Witold als Beweis der Unzurechnungsfähigkeit und des Wahnsinns.

${ }^{568}$ Vgl. Jerzy Jarzębski, Gra w Gombrowicza [Das Gombrowiczspiel], Warszawa 1982, S. 466. Jarzębski scheint jedoch mit seinem Fazit nur das Ende der Szene gedeutet zu haben.
} 
konstituieren, „da die Sinnstruktur bei Gombrowicz eine horizontale und nicht eine vertikale ist. Das bedeutet, dass der Sinn nicht versteckt ist, unter der Oberfläche der Dinge und Ereignisse verborgen, wie bei Freud, sondern er entsteht als Effekt der Beziehungen zwischen ihnen." ${ }^{569}$ Markowski stellt diese These auf, nachdem er die Spezifik der in Kosmos mehrmals wiederkehrenden Erdklümpchen analysierte und zu dem Fazit kam, dass ihr Geheimnis und ihre Unbegreiflichkeit nicht darauf beruhen, dass sie auf Verborgenes (bzw. Verdrängtes) verweisen, sondern darauf, dass sie plötzlich manifest ${ }^{570}$ werden. So gesehen, „sind die Gombrowiczschen Klümpchen und Stäbchen gar nicht geheimnisvoll, sondern unsinnig.“" ${ }^{571}$ Genauso unsinnig sind die sich zu einer imaginierten Falle arrangierten Steine, Wurzeln und Erde. Sie verweisen auf nichts, sie sind lediglich für den Erzähler manifest geworden, obwohl sie es früher nicht waren, ihr Ans-Licht-Kommen erzwingt jedoch ein Verlangen nach Sinn, den die vertraute Logik nicht liefern kann. Die Entdeckung der Erdklümpchen macht Markowski, indem er das Potential Kosmos' im Hinblick auf seine Unheimlichkeit untersuchte. Seine Deutung scheint somit die Freudschen Schlussfolgerungen einleuchtend erweitert zu haben. In Kosmos lässt sich daher das Treiben sowohl der verdrängungsartigen, d.h. der psychisch bedingten, als auch der kosmisch-ontologischen Unheimlichkeiten wahrnehmen. Das literarisch-ästhetische Raffinement der zweiten Sorte des Unheimlichen ist allem Anschein nach eine eigenartige Qualität Gombrowiczscher Literatur. Aber eine mit Unheimlichkeiten gespickte Literatur bedeutet vor allen Dingen ein Herausfordern des leserlichen Wahrnehmungs- und Deutungsvermögens. Ein Zuviel an Verwirrung mag ein „fürchterliche[s] Doppelsehen ${ }^{572}$, das sich als Riss in der Wirklichkeit empfinde“ 573

\footnotetext{
${ }^{569}$ Michał Paweł Markowski, a.a.O., S. 149. [„(...) struktura sensu u Gombrowicza jest horyzontalna, nie wertykalna, co oznacza, że sens nie jest schowany, ukryty pod powierzchnią rzeczy i zdarzeń, jak u Freuda, ale powstaje jako efekt relacji między nimi."] Man könnte an dieser Stelle die These riskieren, die horizontale Sinnstruktur gehöre zu den wichtigsten Errungenschaften der Postmoderne. Gemeint damit wäre ein mehr oder weniger radikal vollzogene Abschied von der Tiefe und dem, doppelten Boden' und eine permanente Affirmation der Oberfläche. In raffinierter Literatur, wie der Gombrowicz', wird die Existenz einer Tiefendimension trickreich vorgetäuscht. Man bemüht nicht selten Konzepte und Begrifflichkeiten namhafter Philosophen, um diese Dimensionen ergründen zu können (Siehe meinen Exkurs zu diesem Kapitel.) Es zeigt sich aber, dass die entscheidende Kraft, die die Handlungen der Gombrowiczschen Figuren determiniert, ist das ,Zwischenmenschliche' und die davon unzentrennliche ,Form', die man sich gegenseitig aufzwingt und von der man vergeblich zu fliehen sucht. Beide lassen sich, wie es der Autor Kosmos' gekonnt darzustellen wusste, auf der Oberfläche hervorragend inszenieren.

${ }^{570}$ Sie wurden so manifest, wie manifest Erdklümpchen (in einer für sich natürlichen Umgebung) nur sein können. Weil sich das Manifest-Sein, worauf Fotis Jannidis aufmerksam macht (Vgl. Fotis Jannidis, Figur und Person. Beitrag zu einer historischen Narratologie, Berlin New York 2004, S. 59.), skalieren lässt, wurden die Erdklümpchen, durch sein plötzliches Aus-dem-Zusammenhang-Gerissen-Sein maximal manifest, was jedoch noch nicht bedeutet, dass sie dadurch sinnhaft werden. Das Gegenteil war hier eher der Fall.

${ }^{571}$ Ebd., S. 150. [„,(..) to Gombrowiczowskie grudki i patyki nie są wcale tajemnicze, ale bezsensowne”]

572 Das fürchterliche Doppelsehen kann unter Umständen an den Jelinekschen schielenden Blick erinnern.
} 
verursachen, ein unerträgliches Gefühl, das die Lektüre in eine Qual verwandeln kann. Wie und ob der Leser das fürchterliche Doppelsehen von sich abzuschütteln vermag, hängt von der entsprechenden Annäherung an den Text des Romans ab, ihre volle Überwindung ist, wie es jedoch scheint, programmatisch nicht möglich.

Sich strategisch an Kosmos anzunähern, bedeutet meines Erachtens in erster Linie die Lokalisierung der Zentren der (potentiellen) Sinnbildung. Ich würde vier solcher Zentren bestimmen: Das Sich-aufeinander-Beziehen, die Selbstigkeit, das Grebebsen und das Eindringen. Das erste, auf Basis assoziativer Verweise des Erzählers aufgebaute Zentrum, dynamisiert schnell das Romangeschehen und konzentriert die Aufmerksamkeit des Lesers. Das Bedeutungsversprechen bleibt bis zu den letzten Seiten Kosmos ' aufrechterhalten und muss höchstwahrscheinlich in eine Enttäuschung münden. ${ }^{574}$ Das potentielle Sinnzentrum erweist sich als Ort der Sinnzerstreuung. Die Selbstigkeit, recht spät ins Geschehen eingeführt, scheint dagegen den Leser von den wuchernden Assoziationen des Protagonisten zu erlösen. Besonders sinnverdächtig wäre dabei die Tatsache, dass ihr Wahrnehmen immer die altbekannte Reihe der hängenden Objekte (bzw. eines davon) evoziert. Der zunächst nicht zu erwehrende Eindruck, dass man in der Selbstigkeit den Schlüssel zum Sich-aufeinanderBeziehen gefunden hat, musste leider in die nächste Enttäuschung münden. Aus der Tatsache, dass Selbstigkeit bei dem Priester, Jadeczka und Leon diagnostiziert wird, lassen sich keinerlei logische Verknüpfungen mit anderen Ereignissen erstellen. Das Ritual des Grebebsens, obwohl es scheinbare Affinität zur Selbstigkeit aufweisen könnte, verwirrt endlich den Leser durch die Fülle seiner möglichen Bedeutungen. „Leon zelebriert in einer gezielt desemantisierten Rede die eigene Verfügungsgewalt über die Sprache und reißt dadurch noch die letzten Brücken intersubjektiver Verständigung ab. Die kommunikative

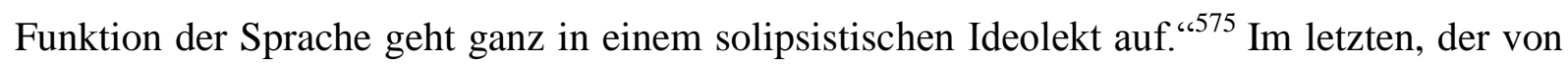
mir lokalisierten Zentren potentieller Sinnbildung, dem Eindringen (,dessen da draußen') chiffriert Gombrowicz seine Deutung der Wirklichkeitskonstituierung. Bis auf die Szene der dummen Falle, werden Momente des Eindringens in kleinen Häppchen in dem ganzen Kosmos verstreut und ohne besonders aufdringlich zu sein, signalisieren sie dem Bewusstsein eine Störung innerhalb seiner Strukturen. Defekt scheint die Möglichkeit des nachhaltigen

\footnotetext{
${ }^{573}$ Witold Gombrowicz, Tagebuch 1953-1969, München Wien 1988, S. 158. Dieses fürchterliche Doppelsehen suchte Gombrowicz in einem ganz anderen Kontext heim. Sein treffendes Verknüpfen mit Kosmos verdanken wir Markowski. Vgl. Michał Paweł Markowski, a.a.O., S. 37.

${ }^{574}$ Weil es nämlich nicht anzunehmen ist, dass das Prinzip des Hängens die ganze Assoziationslogik regiert.

${ }^{575}$ Alfred Gall, Performativer Humanismus. Die Auseinandersetzung mit Philosophie in der literarischen Praxis von Witold Gombrowicz, Dresden 2007, S. 371.
} 
Abspeicherns der wahrgenommen Daten zu sein, ,jede gebildete Anordnung oder ,Konfiguration“ bedeutet nur ein momentanes Ereignis, eine lokale Konzentration, augenblickliche Kristallisierung ${ }^{6576}$, die von dem baldigen Zerfall bedroht ist. Der Prozess der Wirklichkeitsbildung ist daher in Kosmos unzertrennlich mit der wachsenden Zerstreutheit des Erzählers verbunden. Aber eben diese Zerstreutheit dynamisiert ständig das Geschehen des Romans, das wiederholte (punktuelle) Entgleisen der heimlichen Welt, in dem ihre vertraute Sinnhaftigkeit schwindet, intensiviert ihr Sein. ${ }^{577}$ Die Intensität der zu wahrnehmenden Wirklichkeit kann aber das Fiasko der Bildung stabiler, nachhaltiger Sinnstrukturen nicht kompensieren. Es ist einerseits schwer anzunehmen, dass sich die ganze Bewusstseinsanstrengung Witolds in der Dynamik der sich verdrängenden Logiken erschöpfen könnte, andererseits ist die Einsicht, dass „die Bewusstseinsarbeit des Erzählers [...] in sich auf eine paradoxe Art und Weise das Konstruieren der Wirklichkeit mit ihrem Zerfall verbindet ${ }^{\star 678}$, die einzige plausible Erkenntnis, die sich dem Roman entnehmen lässt.

Nicht ohne Grund sieht man in Kosmos eine literarische Konfrontation mit dem Chaos par excellence, der als eine dynamische Kraft als die Antithese der Form konzipiert wird. ${ }^{579}$

Das Treiben des Chaos' (d.h. ,dessen da draußen, der ganzen Welt') vollzieht sich in dem letzten Roman Gombrowicz‘ durch die Gegenüberstellung der Reiz- und Dingüberflutung mit der Sinnverknappung, die der Überflutung nicht standhalten kann. Der Unerträglichkeit dieser Situation wird Abhilfe geschaffen, indem man Strategien des Sinnleihens entfaltet. Diese Taktik lässt sich in der Analyse der Sinnkonstituierung in der Mikroskala erkennen.

In seiner im Kontext der Sinnbildung durchgeführten Untersuchung Kosmos' schlägt Kazimierz Bartoszyński vor, zwei Räume des Romans zu unterscheiden. Als eine Art neutraler Hintergrund eröffnet sich im Text zunächst ein Raum, der im Sinne eines chaotischen, absurden Nullzustands wahrgenommen wird. ${ }^{580} \mathrm{Er}$ wird im Roman durch Anhäufung, Abgrund, Wirrwarr, Gedränge, Türmung, Vorstürzen und allgemeines

\footnotetext{
${ }^{576}$ Andrzej Zawadzki, Gombrowicz a myśl słaba [Gombrowicz und das schwache Denken], in: Jerzy Jarzębski (Red.) Witold Gombrowicz. Nasz współczesny. [Witold Gombrowicz. Unser Zeitgenosse], Kraków 2010, S. 133. [„Każdy budowany układ czy „konfiguracja” to momentalne wydarzenie, lokalne skupienie, chwilowa krystalizacja (...)"]

${ }^{577}$ Vgl. Michał Paweł Markowski, a.a.O., S. 89. Die Intensität der entgleisten Welt verbindet Markowski mit Selbstigkeit mancher Figuren Gombrowicz', jedoch nicht im Kontext Kosmos'.

${ }^{578}$ Alfred Gall, Rozgrywka z filozofiq. 'Bycie i czas' Martina Heideggera w maszynerii 'Kosmosu' Witolda Gombrowicza [Eine Spielpartie mit der Philosophie. 'Sein und Zeit' Martin Heideggers in der Maschinerie ,Kosmos" Witold Gombrowicz'] In: Jerzy Jarzębski (Red.) a.a.O., S. 356. [„Praca świadomości narratora (...) łączy w sposób paradoksalny konstruowanie rzeczywistości z jej unicestwieniem."]

${ }^{579}$ Vgl. Arkadiusz Kalin, Chaos Kosmosu Gombrowicza. [Der Chaos des Kosmos' Gombrowicz'], in: Jerzy Jarzębski (Red.), a.a.O., S. $425 f$.

${ }^{580}$ Vgl. Kazimierz Bartoszyński, Kryzys czy trwanie powieści [Die Krise oder das Fortbestehen des Romans], Kraków 2004, S. 347.
} 
Durcheinander gekennzeichnet. Im Prozess des Emporkommens der Sinnhaftigkeit bildet sich ein weiterer Raum, den Bartoszyński als das potentielle Wahrnehmungsfeld bezeichnet: „In diesem Feld herrscht eine ,hohe Spannung der Semantisierung', d.h. eine Atmosphäre des generellen Sinnleihens - auch den Elementen, die grundsätzlich inkohärent und isoliert sind [...] “581 Wenn sich also in Kosmos zwei Sinnsorten, eine kriminelle und eine sexuelle bestimmen lassen, denn „der ganze Raum des Romans [...] impliziert Konnotationen (oder einen Verdacht der Konnotationen) entweder sexueller oder verbrecherischer Art ${ }^{\text {“582 }}$, dann vollzieht sich das Romangeschehen im Sinne eines semantischen Experiments, in dem abwechselnd Momente des Sinnleihens und Sinnentzugs zum Ausdruck kämen, getrieben durch Erscheinen und Schwinden der funktionalen Bezugssysteme. ${ }^{583}$ In solcher Konzeption bewegt sich der Protagonist von einem desemantisierten zu einem dünn semantisierten Raum, wo er momentane Sinnbildungen in kurzen Sinnleihaktionen bewerkstelligt, um dann wieder zu dem Zustand der Sinnentleerung zurückzukommen. Mit dem Verlassen Warschaus und des Elternhauses scheint Witold somit symbolisch die heimliche Welt der vertrauten Sinnbildung verlassen zu haben. In der künstlichen Wirklichkeit des neuen Ortes herrscht aber ein Zustand des permanenten Sinnmangels. Angesichts dieser Verknappung und der drohenden Verwirrung entfaltet er also die Strategie des Sinnleihens, in der Objekten, Gefühlen, Beziehungen Sinn mit einer kurzen Ausleihfrist geliehen wird. Am Ende darf Witold in die alte Welt wieder zurückkommen und da ist das Hühnerfrikassee zu Mittag an dem richtigen Ort und braucht nicht mit dem geliehenen Sinn sinnhaft gemacht zu werden.

Indem ich Bartoszyńskis Analyse der Bedeutungskonstituierung in Kosmos als grundsätzlich überzeugend annehmen würde, möchte ich sie noch um die Lokalisierung der Momente des Eintretens in die künstliche Welt und ihres Verlassens ergänzen. Die Lockerung der herkömmlichen Logik wird schon auf den ersten Seiten durch die Enumeration der chaotisch wahrgenommenen Dinge ${ }^{584}$ vorbereitet. Wesentlich dynamischer wird jedoch der Abschied von der imaginierten Welt konzipiert. Ein Augenblick davor, bevor der Platzregen einsetzt, meldet sich noch in dem letzten sinn- und kommafreien Aufwuchern von

\footnotetext{
${ }^{581}$ Ebd. [„WW polu tym panuje 'wysokie napięcie semantyzacji', czyli atmosfera generalnego użyczania sensu także elementom w zasadzie niespójnym i izolowanym [...]”]

${ }^{582}$ Ebd., S. 347f. [”, [...]cała bowiem przestrzeń powieści [...] implikuje konotacje (lub podejrzenie konotacji) bądź seksualne bądź przestępcze."]

${ }^{583}$ Vgl. ebd., S. 348f.

${ }^{584}$ Die Enumerationen greifen die vertraute Logik deswegen an, weil sie als Ausdruck der absoluten Beziehungs- losigkeit zwischen den aufgezählten Dingen fungieren. Als solche signalisieren sie die ersten Symptome des Weltzerfalls. Vgl. Michał Paweł Markowski, a.a.O., S. 89.
} 
Assoziationen die schwere, besondere, private Logik. ${ }^{585}$ Und dann begann es ,in Strömen zu gießen. Lose, dicke Tropfen“ $(K, 182)$ und zig andere Dinge, wieder mit Kommata voneinander getrennt, ganz wie früher aber doch irgendwie anders. Wie gut passt das alles auf einmal, wie logisch entspringen Verknüpfungen, wie fließend und leicht erreicht man das Ende.

Könnte man den ganzen Text Kosmos 'im Sinne einer Wanderung erleben, würde man auf den den Ausflug dokumentierenden Fotos folgende Charakteristika des Terrains feststellen:

„Wir haben die Bewegung von dem Komma, über den Punkt bis hin zum Schwinden der Interpunktion. Am Anfang verbindet Witold den Spatzen, das Stäbchen usw., mit dem Komma, dann wird jedes der Objekte für einen Moment zu einem Begriff; es bildet eine getrennte, aus einem Element gebildete Serie (Der Spatz. Das Stäbchen.) [...] Am Ende verschwinden sowohl die Großschreibung als auch die Interpunktion. [...] Wir erreichen [...] die reine Potenz ohne jede Spur, die eine grammatische Figur hinterlässt. Uns übrig bleibt ein Katalog, dessen Elemente mit nichts getrennt sind; somit verschwindet auch das ,zwischen“. ‘586

Obwohl Michał Okłot in seiner Aufzeichnung die Quarantäne des Regengusses ausgelassen hat, scheint seine Skizze den Grundmechanismus des Funktionierens der privaten Logik aufzudecken. Bestätigt wird somit der in den früheren Analysen konstatierte, allmählich fortschreitende Wirklichkeits- und Apperzeptionszerfall im Roman, in dem den schwindenden Beziehungen zwischen den Dingen die schwindende Interpunktion entspricht.

Von der Wahrnehmung der ersten Erdklümpchen bis zum Regenguss breitet sich in Kosmos ein irrsinniges Laboratorium aus, in dem das Bewusstsein des Erzählers Apperzeptionsexperimenten unterzogen wird. Als Erstes getestet wird das Wahrnehmungsvermögen in der Mikroskala der Wirklichkeit, die „erdrückende Fülle von Verbindungen, Beziehungen ...“ $(K, 37)$ überfordert jedoch schnell den Experimentator und er „schaute auf das Haus und das Gärtchen - diese großen synthetischen Gestalten, riesige

\footnotetext{
585 , [...] ich dachte der Spatz Lena Stäbchen Lena Kater in den Mund Honig Lippe ausrenken Wand Erdkrumme Riß Finger Ludwik Gebüsch hängt hängen Mund Lena allein dort Teekanne Kater Stäbchen Zaun Straße Ludwik Priester Mauer Kater Stäbchen Spatz Kater Ludwik hängt Stäbchen hängt Spatz hängt Ludwik Kater ich werde aufhängen ---“ $(K, 182)$

${ }^{586}$ Michał Okłot, ,Możliwość fantasmagorii z hipopotamami', czyli obraz materii u Gombrowicza ['Die Möglichkeit der Phantasmagorie mit den Nilpferden', d.h. das Bild der Materie bei Gombrowicz], in: Jerzy Jarzębski (Red.), a.a.O., S. 406. [ [...] mamy ruch od przecinka, przez kropkę, do zaniku interpunkcji. Na początku Witold łączy wróbla, patyk itd. przecinkiem, później każdy z elementów staje się na chwilę terminem; tworzy oddzielną jednoelementową serię (Wróbel. Patyk.) [...] Wreszcie wielkie litery jak i interpunkcja znikają. [...] Osiągamy [...] czystą potencję, pozbawioną nawet śladu, jaki zostawia figura gramatyczna. Zostajemy z katalogiem, którego elementy nie są niczym oddzielone; znika tedy i „pomiędzy”.]
} 
Mastodonte der Dingwelt, stellten die Ordnung wieder her $[\ldots]^{“}(\mathrm{~K}, 37)$ Diese strategische Beschränkung der Reizüberflutung bringt jedoch keine Erkenntnis hervor, die Einsicht, „die Mikroskala der Wirklichkeit generiere eine die menschliche Möglichkeiten übersteigende

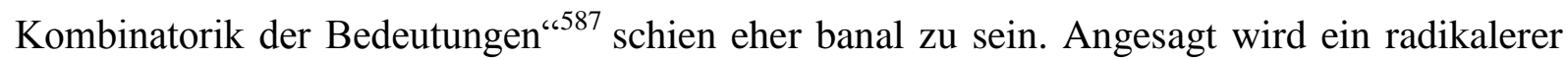
Schritt, Simulation des von der vertrauten Perzeption abweichenden Wahrnehmens, ein Sprung in Paralogie. ${ }^{588}$ Das Konstruktionsprinzip, das dabei strategisch erprobt werden sollte, war das einer Bastelei:

„[...] ohne einen Plan handelnd, improvisierend 'arbeitet sie Reihen von Elementen mit bestimmter Struktur, auf Basis von Resten und Überresten der Ereignisse' aus, die nach früheren Konstruktionen und Destruktionen übriggeblieben sind. Sie bilden eine Art [...] verfügbarer Mittelreserve, die entweder als Stoff oder als Instrumente zum kaleidoskopischen Rearrangement genutzt werden sollen, in dem nicht die Natur der Einheiten, sondern ihre Funktionen und Bedeutungen geändert werden.“589

Das bastelnde Bewusstsein braucht sich nicht mehr um die drohende Reizüberflutung zu kümmern, da man aufhörte, den Sinnüberfluss als ein zu bewältigendes Problem zu betrachten. In den dynamisch verlaufenden De-Re-Konstruktionen sind es nämlich nicht mehr Bedeutungen, die ihre Enthüllung fordern, sondern die Zeichen, die sich sehr leicht mit anderen Zeichen assoziieren lassen und die erst „für eine Struktur ,appellieren“, in der sie

\footnotetext{
${ }^{587}$ Arkadiusz Kalin, Chaos 'Kosmosu' Gombrowicza. [Das Chaos Kosmos' Gombrowicz'], in: Jerzy Jarzębski (Red.), a.a.O., S. 432. [„Mikroskala rzeczywistości generuje przerastającą ludzkie możliwości kombinatorykę sensów.”]

${ }^{588}$ Paralogie ist „falsche Schlussfolgerung trotz richtiger Voraussetzung. In der Psychiatrie Form einer Denkstörung. Besteht darin, >>dass die im Gedankenzusammenhange zunächst sich darbietende Vorstellung unterdrückt und durch eine andere, ihr verwandte, ersetzt wird << (Kraepelin) Dem Denken geht damit der logische Zusammenhang verloren, wodurch das Verständnis für andere erschwert oder unmöglich wird." Uwe Henrik Peters, Lexikon Psychiatrie Psychotherapie Medizinische Psychologie, München Jena 2007, S. 386. Kalin versteht paralogisches Denken nicht nur im Sinne eines psychologischen Phänomens, sondern sondiert nach Lyotard seinen Nutzen für die Beschreibung der Kondition der Wissenschaft und der Kultur. Lyotard entfaltete ein neuartiges Verständnis der Paralogie, indem er diesen Begriff mit Formen der kleinen Erzählungen, wie offene Systematik, das Lokale oder die Antimethode verbindet. Als ein „oft unterschätzter Zug in der Pragmatik des Wissens" fungiert Paralogie als eine Kraft, die „die Erklärungsfähigkeiten destabilisiert und sich in der Verordnung neuer Normen des Begreifens manifestiert [...]“ Jean-François Lyotard, Das postmoderne Wissen Ein Bericht, Graz Wien 1986, S. 175ff. Gerade die Lyotardschen Paralogien scheinen die Bewusstseinsperipetien Kosmos' treffend zu beschreiben.

${ }^{589}$ Ryszard Nycz, Sylwy współczesne. Problem konstrukcji tekstu [Die zeitgenössischen Silven. Das Problem der Textkonstruktion], Wrocław, Warszawa, Kraków, Gdańsk, Łódź 1984, S. 76. [„działając bez wyraźnego planu, w sposób improwizowany, wypracowuje zespoły o pewnej strukturze, na podstawie resztek i szczątków zdarzeń pozostałych po uprzednich konstrukcjach i destrukcjach. Tworzą one rodzaj [...] podręcznego zapasu środków, które mają zostać użyte bądź jako materiał, bądź jako narzędzia do kalejdoskopowej rearanżacji, w której natura samych jednostek nie ulega zmianie, choć zmieniają się ich funkcje i znaczenia."
} 
bedeuten könnten. ${ }^{6590}$ Im Falle des Spatzen müssen daher die detektivischen Anstrengungen des Protagonisten verworfen werden, ,um die Wirklichkeit als die , mit der Möglichkeit der Bedeutungen infizierte "verspüren zu können und die sich in der Serie der signifikanten Ereignissen allmählich enthüllende ,Idee des Hängens“ zu erblicken.“ ${ }^{591}$ Der bastelnde Erzähler erinnert in dieser Praxis ein wenig an Sokrates, der strategisch vorgehend, widersprüchliche Werte entgegenzustellen suchte, um auf diesem Wege den Prozess der emporsteigenden Begriffe von den Zweifeln zu bereinigen. Ob aber der am Ende erreichte Punkt zwischen Sinn- und Unsinnhaftigkeit das Bewusstsein mit befreiender Kakophonie beschert? ${ }^{592}$ Die nüchterne Auswertung unbekümmert getriebener Bastelei kann leider nichts dergleichen bestätigen:

„Ich war noch immer verwirrt, ich wusste nicht ein noch aus, so viele, so viele Fäden, Verknüpfungen, Insinuationen, wenn ich alle von Anfang an aufzählen wollte, Kork, Untersatz, das Zittern der Hand, der Schornstein, ich würde mich verlieren, ein Gestöber von Dingen und nicht genau umrissenen Angelegenheiten, die kaum einen Sinn ergaben, immer wieder verband sich, verzahnte sich die eine oder andere Einzelheit mit der anderen, aber schon wuchsen neue Verbindungen, neue Richtungen - davon lebte ich, mehr schlecht als recht [Hervorhebung - K.S.] ${ }^{593}$, ein Chaos, ein Haufen Müll, ein Brei - ich steckte die Hand in die Mülltuite, zog heraus, was mir in die Finger kam, und guckte, ob es sich eignete zum Bau ... meines Häuschens ... das, armes Ding, die phantastischsten Formen annahm ... und so ohne Ende.“ $(K, 126)$

Was den Erzähler beherrscht, ist die wachsende Skepsis, eine mit Angst unterfütterte Unsicherheit, dass man sich vielleicht auf dem Weg ins Innere seines Selbst vergaloppiere. Was einem Bewusstsein, das sich zu sehr in seine Tiefen verirrte droht, ist das Grauen, dass man sich auf einmal im Haus des autistischen Ichs eingesperrt findet. ${ }^{594}$

\footnotetext{
${ }^{590}$ Ebd., S. 78. Nycz spricht hier von flüssigen Bedeutungen, die einen sehr geringen symbolischen Wert besitzen. Dieser Mangel „garantiert ihm [dem Zeichen - K.S.] eine unheimliche Polyfunktionalität, die ihm ermöglicht, verschiedene syntaktische Positionen zu besetzen, die Form unterschiedlicher Wortklassen anzunehmen [...]“ Ebd., S. 79. [„zapewnia mu niezwykłą polifunkcjonalność, umożliwiającą zajmowanie rozmaitych pozycji składniowych, przybieranie form różnych części mowy [...]"]

${ }^{591}$ Ebd., S. 81 [„,by móc odczuć rzeczywistość jako 'zakażoną możliwością znaczeń' i dostrzec w serii znaczących zdarzeń stopniowo wyłaniającą się 'ideę wieszania'."]

${ }^{592} \mathrm{Vgl}$. Dorota Wojda, Niegrzeczny Gombrowicz O kommunikacji ponad regułami [Der unartige Gombrowicz Über Kommunikation außerhalb der Regeln], in: Jerzy Jarzębski (Red.), a.a.O., S. 725. Das Gefühl der befreienden Kakophonie brachte Wojda aus einem ganz anderen Kontext als die Untersuchung Kosmos' hervor. Ähnlich meiner Analysen sind jedoch die von Wojda genannten Etappen, die in solche Kakophonie mündeten.

${ }^{593}$ Ich habe die Phrase hervorgehoben, weil der Übersetzer die polnischen Worte, jakbym nie żył' falsch übersetzte. Es heißt: ,als wenn ich nicht lebte', was darauf hinweist, wie sehr die Wahrnehmungspraxis der Protagonisten seine Lebensintensität inzwischen erdrückt.

${ }^{594}$ Vgl. German Ritz, a.a.O., S. 529.
} 
Der oben erwähnte Punkt zwischen der Sinn- und Unsinnhaftigkeit bildet meiner Meinung nach einen signifikanten Grenzort auf dem Weg des Bewusstseins zur Sondierung seiner Überlebenstaktik angesichts der drohenden Entgleisungen der Welt. Die Praxis der Bastelei hat ihren Sinn, weil man uns dadurch mit Zeichen reichlich versorgt. Das Ziel dieses Spiels ist es aber, jedes Zeichen mit mindestens irgendeinem anderen Zeichen zu verbinden, d.h. jede Bastelei ist darauf ausgerichtet (irgendwelche) Beziehungen zu knüpfen. Kein Zeichen darf auch zu lange unverbunden bleiben, da sein Sein irgendwann dem Bewusstsein unangenehm aufdringlich erscheinen mag. Es bleibt also nichts anderes als konsequent und solide zu kombinieren und „was ist da leichter, als zu kombinieren!“ (K, 56) Im unschuldigen Rearrangieren der sich kombinierenden Zeichen scheinen wir jedoch nicht zu bemerken, dass jede unsere Geste mit einer Fülle von Möglichkeiten behaftet ist, durch die sie nichts Konkretes nachhaltig hervorheben vermag. ${ }^{595}$ Dieser Zustand der ,allmächtigen Vieldeutigkeit‘, wie es Karpiński nennt oder - anders ausgedrückt - der paranoiden Allsinnhaftigkeit markiert meines Erachtens das Endstadium eines Experiments, dessen Zeugen und/oder Versuchskaninchen wir während der Kosmos-Lektüre sein durften. Das diesem Experiment in Form eines Regengusses radikal gesetzte Ende „suggeriert, dass es reicht, die ursprüngliche Intention des Blicks zu ändern, damit alles wie in einem Kaleidoskop wirbelte, sich in andere Systeme und Bedeutungen einrichtete. ${ }^{\text {“596 }}$

Was bleibt (uns) aber nach dieser bereinigenden Sturmflut? Oder, um anders zu fragen, was ist in Kosmos passiert? Um die Lage des Lesers nach der absolvierten Kosmos-Lektüre richtig einschätzen zu können und eine Art Schlussbilanz ziehen zu können, möchte ich noch einmal auf eines der Theoreme der Psychoanalyse zurückgreifen und zwar auf den ,Tagtraum‘. Der Begriff, der in der psychoanalytischen Interpretation als Mittelglied zwischen dem Traum und dem Kunstwerk fungieren sollte, bezeichnet „die vorgestellte Wunscherfüllung des Wachzustandes [und als solcher berücksichtigt] stärker als der Traum das Realitätsprinzip. “597 Als Erstes möchte ich in dieser Optik die Situation des Erzählers erkunden. Die Entwicklung seiner Erzählung weist nämlich eine allmähliche Entgleisung von der vertrauten Logik und der üblichen Wirklichkeitswahrnehmung auf, was ihn in eine Art Tagtraum versetzt. Witolds Kontakt zur äußeren Wirklichkeit wird zwar im Laufe des Romangeschehens nie radikal unterbrochen, die Spezifik seiner Weltrezeption lässt sich

\footnotetext{
${ }^{595}$ Vgl. Wojciech Karpiński, Gombrowiczowska przestrzeń [Der Gombrowiczsche Raum], in: Zdzisław Łapiński (Hg.), Gombrowicz i krytycy [Gombrowicz und Kritiker], Kraków Wrocław 1984, S. 179.

${ }^{596}$ Ebd., S. 179 [, [...] sugeruje, że wystarczy zmienić pierwotną intencję spojrzenia, aby wszystko zawirowało jak w kalejdoskopie, ułożyło się w inne układy i znaczenia."]

${ }^{597}$ Walter Schönau, a.a.O., S. 86.
} 
jedoch nur noch im Sinne einer ,privaten` Logik erfassen. Sein (unbewusster) Wunsch wäre die Logik des Sich-aufeinander-Beziehens zu dechiffrieren. Die Wunscherfüllung vollzieht sich durch das Verbinden der Münder mit dem Hängen, in der Geste des Fingersteckens in den Mund des Hängenden. Zu fragen wäre noch, ob das Einschalten der Perspektive des ordnend-kommentierenden Erzählers die Unterbrechung des Tagtraums zur Folge hätte? Sollte nämlich der Kommentierende auch als der Tagträumende gelten, würde sich seine Rolle in der Anpassung der Wunscherfüllung an das Realitätsprinzip erschöpfen. An dem Punkt, an dem der vereinigte Erzähler seine Aufmerksamkeit dem Hühnerfrikassee widmet, bleibt der wahrscheinlich desorientierte Leser vor einem Dilemma stehen, das seinen Tagtraum (d.h. den Prozess der Lektüre) - um in der psychoanalytischen Optik zu bleiben keineswegs mit der Wunscherfüllung, d.h. mit dem Gewinn der Bedeutung des Romans als Ganzes, abschließen lässt. Eine Menge explizit und implizit gestellter Fragen in der Makround Mikroperspektive überflutet das Gedächtnis des Lesers und lässt ihn mit großer Mühe höchstens die möglichen Antwortvarianten sondieren.

Was ist also in Kosmos passiert? Mit der Makroperspektive beginnend, war das die „Formung des Formlosen [...], die unter dem Eindruck des Geformtseins“ ${ }^{\text {(598 }}$ geschah, das „Entstehen der Wirklichkeit, von dem, wie sie ungeschickt, lahm, aus unseren Assoziationen geboren wird“" ${ }^{699}$, der Zerfall der Welt ,in Stücke unter dem Andrang des unbegreiflichen

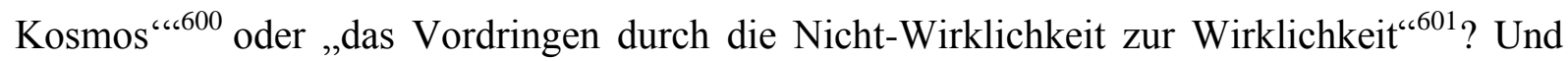
aus der Mikroperspektive blickend? Hat sich das Hängen verselbständigt und den Status eines autonomen Diskurses erlangt? Erschöpft sich das Grebs-Ritual im Kontext des Sexuellen? Welche, im Rahmen der detektivischen Ermittlungen registrierte Zeichen lassen sich als intersubjektiv nachvollziehbare einstufen und welche sollten dem wahnhaften Assoziationsdrang des Erzählers zugeschrieben werden? Die chaotische Verschachtelung der Sinnbildungsmomente in der Mikro- und Makroskala lässt jede der obigen Deutungen bestätigen, denn der mit Paralogien gespickte, mit Unheimlichkeit unterfütterte, bastelnd komponierte und paranoide Züge aufweisende Text Kosmos ' will eben darauf zielen und sich darin erschöpfen, den Leser auf den Irrweg der Desorientierung zu führen.

Ähnlich wie Pynchons CL 49 habe ich auch Gombrowicz' Kosmos, an der Schnittstelle zwischen Moderne und Postmoderne situiert. Weit subtiler als Pynchon und Jelinek steigert

\footnotetext{
${ }^{598}$ Birgit Harreß, a.a.O., S. 223.

${ }^{599}$ Witold Gombrowicz, Eine Art Testament, München Wien, 1996, S. 132.

${ }^{600}$ Michał Paweł Markowski, a.a.O., S. 150. [„na kawałki pod naporem niezrozumiałego kosmosu”]

${ }^{601}$ Vgl. Jerzy jarzębski, Gra w Gombrowicza, Warszawa 1982, S. 108.
} 
der Autor von Kosmos jedoch die Affirmation der Textoberfläche. ${ }^{602}$ Auch die Ambivalenz scheint hier m.E. eine geringere Entstehungsdynamik aufzuweisen, da sie nicht durch Datenüberflutung (wie in $C L 49$ ) oder durch Fragmentierung (wie in Lust) gestiftet ist, sondern keimt langsam auf dank Strategien (Momenten) wie konkurrierende Erzählerstandpunkte (einerseits der erlebende, andererseits der korrigierende Erzähler), die Thematisierung der Leserrolle ${ }^{603}$ und die Hervorbringung einer privaten Sinnbildungslogik des Protagonisten.

\footnotetext{
${ }^{602}$ Siehe das Zitat von Michał Okłot auf S. 168.

${ }^{603}$ Siehe die von mir zitierte Passage aus Kosmos auf S. 145. Konkurrierende Erzählerstandpunkte und Thematisierung der Leserrolle mögen auch den Lust-Leser irritieren. Die permanente Fragmentierung, das häufige Unterbrechen des Erzählerberichts und kurze, eher provokative Ansprachen an den Leser radikalisieren die Ambivalenz hier weit mehr als in Kosmos.
} 


\subsection{Exkurs: Philosophische (Meta)Desorientierung}

\section{im Kontext der Kosmos-Lesarten}

„Ich möchte als Künstler gelesen werden. Ich hasse diese allzu
philosophische Erklärungen meines Schaffens.“

W. Gombrowicz

Es gibt zweifelsohne nicht viele SchriftstellerInnen, deren Werk - wie es bei Gombrowicz der Fall ist - so viel Irritation und Desorientierung verursacht hat und zwar nicht nur auf der Rezeptionsebene einzelner Texte, sondern auch im Bereich der Forschungsarbeit. Was ich damit meine, hat nichts damit zu tun, dass die Literatur des Autors Kosmos' eine Fülle unterschiedlicher, nicht selten widersprüchlicher Interpretationen inspiriert hat, was im Falle eines schwierigen Schriftstellers oft der Fall ist; es geht mir um ein meines Erachtens falsches Vorgehen mancher Interpreten, die den Werken Gombrowicz' die Fähigkeit der Wissenserzeugung und/oder der Lieferung von Einsichten philosophischer Natur zuschreiben wollen.

Das Problem, das ich im folgenden Exkurs thematisieren und skizzieren möchte, entspringt - in seinem Makrokontext - der Frage nach der Aufgabe und den Möglichkeiten der Literatur als ästhetisch-textuellem Gebilde. Mein sehr bescheidenes Ziel beschränkt sich jedoch hiermit lediglich auf das Beleuchten einer Interpretationsstrategie, die literarischen Werken Fähigkeiten zuschreibt, die sie meines Erachtens nicht besitzen können. Grob gesagt vertrete ich die Meinung, dass fiktionele literarische Werke sich weder um Lösung irgendwelcher Probleme, sei es epistemologischer, ontologischer oder axiologischer Natur bemühen, noch versuchen sie, jene im Sinne der zu lösenden Dilemmata zu betrachten. Der Grund dafür sind das Wesen und der Inbegriff der Kunst, die

„nicht Argument, [sondern] [...] Entladung [sei]. In einem Künstler geschieht alles gleichzeitig, alles wirkt zusammen, Theorie und Praxis, Denken und Leidenschaft, Leben und Wertung und Verstehen des Lebens [...] Diese Mannigfaltigkeit in der Art, den Stoff anzugehen, dies, daß der Künstler ständig auf mehreren Stühlen zugleich sitzt, sichert ihm eine größere Freiheit des Manövrierens. [...] der Widerspruch, welcher der Tod des Philosophen ist, ist das Leben des Künstlers. “604

\footnotetext{
${ }^{604}$ Witold Gombrowicz, Eine Art Testament, München Wien 1996, S. 62f. Ähnliche Momente im Kontext des literarischen Schaffens bringt auch die Schriftstellerin Ulla Lenze hervor: „Die Literatur konstituiert in jedem Moment das, was sie erzählt, als Gesamtheit von Inhalt und Klang in sinnlicher Evokation. [...] Der literarische Text [...] geht über das Diskursive und Verständnisorientierte hinaus."
} 
So gesehen würde sich Literatur in der Affirmation erschöpfen, was jedoch nicht gleich bedeuten muss, dass sie jede Beziehung zur Philosophie brechen sollte. Das komplexe und subtile Verhältnis zwischen den beiden wurde bereits von Platon erkannt und sondiert, der letzlich den „Ursprung der Philosophie in der Abkehr von der Dichtung und deren Verbindung zum Mythos“605 situierte. Platon verdanken wir die Grenzziehung zwischen der dichterischen und philosophischen Sprache, indem er der Philosophie die Qualität eines Metadenkens, d.h. eines Denkens des Denkens zuschreibt und der Dichtung dagegen, die Fähigkeit eines Denkens, das ,durchdringt' verweigert. ${ }^{606}$ Das von Platon zu einem philosophischen Problem erhobene Frage nach dem Unterschied zwischen literarischer und philosophischer Erkenntnis wurde dank Alexander Baumgarten zum Thema der Ästhetik, in der er eine „kritische Instanz zur logischen Erkenntnis“607 suchte.

Es spräche im Grunde nichts dagegen, literarische Äußerungen in der philosophischen Perspektive zu situieren oder für den Gewinn einer neuartigen Deutung, sich philosophischer Begrifflichkeiten zu bedienen. Es ist aber, wie ich meine, verfehlt zu behaupten, literarische Texte können die, durch die philosophische Reflektion ausgearbeiteten Konzepte bestätigen oder falsifizieren, denn ,in der ,Philosophie“ geht es grosso modo darum, die Prinzipien und Gründe der Wirklichkeit mittels Sprache zu erkennen; Aufgabe der ,Literatur` ist es dagegen, künstliche bzw. künstlerische Wirklichkeiten durch Sprache allererst zu erzeugen.“608

An zwei philosophisch inspirierten Interpretationen Kosmos` versuche ich zu zeigen, wann das Vermengen der inkommensurablen Diskurse m.E. zu weit geht und zu ästhetischrhetorisch anziehenden, diskursiv jedoch unzulässigen Schlussfolgerungen führt.

In der Abhandlung Performativer Humanismus. Die Auseinandersetzung mit Philosophie in der literarischen Praxis von Witold Gombrowicz erkennt man bereits im Titel der Arbeit die Annahme ihres Autors, Alfred Gall, dass der Literatur Gombrowicz' unter anderem eine Auseinandersetzung mit der Philosophie zu entnehmen sei. Diese meines Erachtens

http://www.deutschlandradiokultur.de/literatur-vs-philosophie-wovon-man-nicht-sprechenkann.2162.de.html?dram:article_id=320732

${ }^{605}$ Hans Feger (Hg.), Handbuch Literatur und Philosophie, Stuttgart Weimar 2012, S. 1.

${ }^{606}$ Vgl. ebd.

${ }^{607}$ Ebd., S. 4.

${ }^{608}$ Markus Wirtz, Schnittstellen und Demarkationslinien literarischer und philosophischer Textualität In: Martin Roussel, Markus Wirtz, Antonia Wunderlich (Hg.), Eingrenzen und Überschreiten: Ver-fahren in der Moderneforschung, Würzburg 2005, S. 232. Um es noch anders auszudrücken: „Beide, Philosophie und Literatur, repräsentieren nicht, sondern reflektieren Wirklichkeiten, und das hießt die Konstitutionsweisen von Wirklichkeit, aber sie tun dies in unterschiedlicher Weise, als Darstellung oder Denken, als Poiesis oder Analytik ihres Gegenstandes." Eva Horn, Bettine Menke, Christoph Menke, Literatur als Philosophie - Philosophie als Literatur, München 2006, S. 12. 
unbekümmerte Unterstellung wird im Folgenden anhand einiger Ausführungen Galls kritisch reflektiert.

In seiner sonst solide und einleuchtend durchgeführten Analyse Kosmos ' entdeckt der Literaturwissenschaftler angeblich philosophisch geprägte Inhalte und die ihnen gewidmeten Untersuchungen führen ihn zur Behauptung: „In Kosmos [...] wird die Ontologie Heideggers dekomponiert. “609 Im Verlauf des Vergleichs zwischen Kosmos und Sein und Zeit kommt Gall zur Formulierung folgender These:

„Kosmos reicht wesentlich weiter als Sein und Zeit und stellt nicht nur die Frage der ,Weltlichkeit‘ und des ,Entzugs der Weltlichkeit‘, sondern enthüllt eine völlig andere Betrachtung der Welt. In Kosmos vollzieht sich eine völlige Streichung der 'Weltlichkeit'. Während einer ähnlichen Derealisierung offenbart sich die ontologische Unstabilität der Wirklichkeit.“610

Galls Untersuchung wird mit einigen Bemerkungen vorbereitet, deren Relevanz er, wie ich behaupte, nicht richtig erkannte. Wir lesen z.B., dass ein literarischer Text „seine Quellen nicht von philosophischen Annahmen her[leitet], die ihn mit nichts determinieren [und dass] Kosmos sich den Ansprüchen des abstrakten Gedankens entzieht." ${ }^{611}$ Gegen beide Feststellungen ist nichts einzuwenden, ihre Konsequenzen scheint Gall jedoch übersehen zu haben. Wichtiger noch für einen Interpreten, der mit der Absicht forscht, einem literarischen Werk Qualitäten philosophischer Reflexion zu entnehmen, sind weitere Bemerkungen: „Es ist ungewiss, in welchem Sinn das Wort,Wirklichkeit` zu verstehen sei und auf welche Art und Weise sich das Bewusstsein auf diese Wirklichkeit, die es konstruiert, bezieht. “612 Hätte Gall die Relevanz dieser Unklarheiten erkannt, hätte er m.E. auf die Erforschung philosophischer Qualitäten Kosmos ‘ verzichten müssen. Nicht nur in dem letzten Roman Gombrowicz‘ bleibt unklar, was der Autor unter ,Wirklichkeit' versteht, auch viele seiner kommentierenden Äußerungen präzisieren diesen Begriff nicht und erwecken den Eindruck, Gombrowicz gebrauche ihn eher unverbindlich und spontan, je nach Kontext eher assoziativ denn als logisch fundiert.

Die Verwirrung um die, Wirklichkeit‘ wird z.B. im Testament bemerkbar. Das Ziel seiner Literatur formuliert Gombrowicz wie folgt: „Eine der Hauptaufgaben meines Schreibens ist,

\footnotetext{
${ }^{609}$ Alfred Gall, Performativer Humanismus. Die Auseinandersetzung mit Philosophie in der literarischen Praxis von Witold Gombrowicz, Dresden 2007, S. 525.

${ }^{610}$ Alfred Gall, Rozgrywka z filozofiq. 'Bycie i czas' Martina Heideggera w maszynerii 'Kosmosu' Witolda Gombrowicza. [Eine Spielpartie mit der Philosophie. 'Sein und Zeit' Martin Heideggers in der Maschinerie "Kosmos" Witold Gombrowicz'.], in: Jerzy Jarzębski (Red.) a.a.O., S. 362.

${ }^{611}$ Ebd., S. 354

612 Ebd., S. 355.
} 
durch die Unwirklichkeit hindurch zur Wirklichkeit zu dringen. “613 Leider folgen dieser geheimnisvoll-vieldeutigen Anmerkung keine Präzisierungen. Später scheint er jedoch doch einen Hinweis geschmuggelt zu haben: „Denn die Wirklichkeit (dachte ich), diese allgemeine, objektive, ist gar keine Wirklichkeit. Die wahre Wirklichkeit, das ist diese eigene, private."614 Der Protagonist in Gombrowicz vorletzten Roman Pornographie will - nach dem Kommentar des Autors - „,Zu neuen ,Wirklichkeiten“ gelangen”615, den Vertretern des französischen nouveau roman wird dann aber „Unloyalität gegenüber der Wirklichkeit““616 vorgeworfen. Ein Interpret, der in Gombrowicz‘ Werken nach philosophischen Erkenntnissen sucht, muss sich also erst dieser Verwirrung bewusst werden. Gombrowicz' Unbekümmertheit im Umgang mit Begriffen, deren präzise Bestimmung für die philosophische Deutung unerlässlich ist, macht jedoch m.E. alle solche Annäherungen zunichte. Anderer Meinung ist jedoch Gall, der trotz der diagnostizierten Unbestimmtheit des Wirklichkeitsbegriffs, sich dadurch nicht gehindert sieht, die ,Wirklichkeit' Kosmos ' mit der ,Wirklichkeit ${ }^{\star}$ des Heideggerschen Sein und Zeit vergleichen zu können. In seinen Ausführungen ${ }^{617}$, die die Analyse der oben genannten Werke vorbereiten, lassen sich Annahmen herausfischen, die meines Erachtens schwer nachvollziehbar sind. Es ist zum Beispiel unklar, wo „das spannungsgeladene Verhältnis zwischen konzeptuell-systematischer Wirklichkeitserschließung in der Philosophie und imaginativ-metaphorischer Erkundung der Wirklichkeit im literarischen Schreiben“6618 zu diagnostizieren sei. Selbst, wenn der „Verlust der Gegenwart [...] als Erfahrung der Negativität zu begreifen“"619 sei, müsse doch daraus kein Streit zwischen Literatur und Philosophie resultieren, wie es Gall behauptet. Man kann sich hier des Eindrucks nicht erwehren, dass der Literaturwissenschaftler beide Diskurse als miteinander konkurrierende sieht. ${ }^{620}$ Beide sind in dieser Optik Lieferanten von Modellen

\footnotetext{
${ }^{613}$ Witold Gombrowicz, Eine Art Testament, S. 12.

${ }^{614}$ Ebd., S. 30.

${ }^{615}$ Ebd., S. 56. Dieses Mal wird Wirklichkeit auch noch in Anführungszeichen geschrieben, was die Deutung weiterhin erschwert.

${ }^{616}$ Ebd., S. 136.

${ }^{617}$ Gall unterstützt seine Thesen mit dem Konzept der ,ästhetischen Negativität', das von Karl-Heinz Bohrer herausgearbeitet wurde.

${ }^{618}$ Alfred Gall, Performativer Humanismus. Die Auseinandersetzung mit Philosophie in der literarischen Praxis von Witold Gombrowicz, Dresden 2007 S. 116.

${ }^{619}$ Ebd., S. 114.

${ }^{620}$ Es wäre m.E. vorsichtiger, wie es Markus Wirtz tut, ,die Philosophie' und ,die Literatur' als zwei autonome Gebiete zu betrachten; „,Die Philosophie‘ [ließe sich] aufgrund ihrer auf Grundlagenkenntnis ausgerichteten Intention dem epistemisch-propositionalen Bereich der Sprach- bzw. Schriftverwendung zurechnen, während die (schöne) ,Literatur' im modernen Sinne als Ensemble fiktionaler und poetischer Schrifterzeugnisse zweifelsfrei dem Reich der Sprach-Kunst zuzurechnen wäre.“ Markus Wirtz, a.a.O., S. 232. Wirtz versucht die subtilen Unterscheidungen zwischen dem Philosophischen und dem Literarischen hervorzubringen und listet sieben Fälle auf, die die Konstellationsmöglichkeiten zwischen den beiden Sprachverwendungen beschreiben.
} 
oder Konzepten der Wirklichkeit und „die philosophisch geprägte Literatur überbietet die Philosophie, da sie ein unverstelltes Gewahrwerden des Negativen zulässt $[\ldots]^{\text {‘621 }}$ Was sich in Gallschen Augen in diesem kulturellen Kontext abspielt und von ihm begrüßt wird, ist „die Transformation der philosophischen Semantik in der literarischen Praxis [mit der] Zielsetzung der Neugewinnung von Wirklichkeit [... ]6622 Obwohl es, ähnlich wie bei Gombrowicz, nicht klar ist, um welche Wirklichkeit es sich eigentlich handelt, macht Gall „Theorien und Weltvorstellungen [für] eine Entwirklichung von Welterfahrung [verantwortlich, da] die nicht mehr an das empfindende, handelnde, denkende, leidende Individuum zurückgekoppelt ist.“623 Der ,Vorstoß zur Wirklichkeit“, was auch immer es bedeuten könnte, ,erfolgt als Durchbrechung der Positivität philosophischer Begriffsbildung durch Freilegung von Negativität $[\ldots]^{\text {“624 }}$ Verblüffend klingt das Aufzählen der Defizite, indem einer Disziplin, deren Natur Abstraktion und Verallgemeinerung sind, Derealisierung und Entmenschlichung vorgeworfen werden.

Abgesehen von den wenigen Unstimmigkeiten, die Galls Positionierung in dem angeblichen Streit zwischen der Literatur und der Philosophie nicht wirklich erkennen lassen, liefert die Untersuchung des Sein und Zeit gegenübergestellten Roman Kosmos eine einleuchtende und informative Interpretation, gegen die meines Erachtens wenig einzuwenden ist. Die Analysen des Romangeschehens, geführt mit Hilfe Heideggerscher Begrifflichkeit, lassen überzeugende Schlussfolgerungen kreieren und bieten Versuche an, schwierige Momente der Geschichte zu plausibilisieren. Das Problem beginnt jedoch genau an den Orten, wo Gall den diskursiven Unterschied zwischen den beiden Texten zu vergessen scheint und/oder diesen ignoriert. Als verdächtig erscheint beispielsweise die Strategie, in der er ein Phänomen des Romangeschehens interpretiert und dieses mit einem Begriff versieht, um jenen dann einem aus Sein und Zeit stammenden Begriff gegenüberzustellen. So wird z.B., die in Kosmos diagnostizierte ,Derealisierung der Welterfahrung ‘ mit der im Werk Heideggers herausgearbeiteten ,Entweltlichung ${ }^{6}$ verglichen ${ }^{625}$, als ob beide Ideen eine vergleichende epistemische Zuverlässigkeit ${ }^{626}$ aufweisen könnten. Eine Serie solcher kleinen diskursiven

\footnotetext{
${ }^{621}$ Alfred Gall, Performativer Humanismus, S. 115.

${ }^{622}$ Ebd., S. 117.

${ }^{623}$ Ebd.

624 Ebd.

${ }^{625} \mathrm{Vgl}$. Alfred Gall, Rozgrywka z filozofiq, a.a.O., S. 352ff u. Performativer Humanismus. S. 383.

${ }^{626}$ Die epistemische Unzuverlässigkeit ist eines der vier antikognitivistischen Argumente: „Fiktionale literarische Werke können uns zwar wahre Überzeugungen vermitteln, sie können uns aber kein Wissen vermitteln, weil wir nicht gerechtfertigt sind, diese Werke als zuverlässige Quellen anzusehen - es sei denn, wir prüfen die Zuverlässigkeit der fiktionalen Quellen durch andere, nichtfiktionale Quellen, zum Beispiel Geschichtsbücher.
} 
Sünden führt im Fall Galls dazu, dass er in der Zusammenfassung seiner Abhandlung behauptet, „Gombrowiczs literarische Praxis verläuft als Auseinandersetzung mit Philosophie und kann als Revision philosophischer Weltbilder sowie als Neuerschließung noch nicht begrifflich zu Aussagesätzen verdichteter Dimensionen des Wirklichen gelten. “627 Das Manko solcher subtilen Übersehungen beruht meines Erachtens darauf, dass sie den Lesern ohne Philosophiekenntnisse ein falsches Signal geben, dass den literarischen sowie den philosophischen Texten diskursiv vergleichbare Qualitäten entnommen werden dürfen.

Ein weiteres Beispiel ,diskursiver Unbekümmertheit' fand ich im Aufsatz Michał Januszkiewiczs, der Kosmos als Auseinandersetzung mit dem Problem der Metaphysik wahrnimmt und ähnlich wie Gall dem Roman philosophische Leistungen entnimmt. Anders als der Autor von Performativer Humanismus macht sich Januszkiewicz jedoch die Mühe, die in seiner Analyse gebrauchten Begriffe zu definieren. So wird der Leser gleich am Anfang der Untersuchung darüber informiert, was hier unter ,Metaphysik ${ }^{628} \mathrm{zu}$ verstehen sei, auch der geschichtsphilosophische Kontext wird knapp erwähnt und das Wissen der altgriechischen Philosophen mit den dem Kosmos entnommen Erkenntnissen verglichen. Und eben in diesem Vergleich, oder vielleicht nur in dessen Formulierung, ist Januszkiewicz meines Erachtens zu

In letzterem Fall würden wir unser Wissen aber den Geschichtsbüchern verdanken, nicht dem fiktionalen Werk." Maria E. Reicher, Können wir aus Fiktionen lernen? in: Christoph Demmerling/Íngrid Vendrell Ferran (Hg.), Wahrheit, Wissen und Erkenntnis in der Literatur, Berlin 2014, S. 77. „Ästhetischer Antikognitivismus besteht [...] in der Ablehnung entweder der These, dass wir durch Kunstwerke Wissen erwerben können, oder in der Ablehnung der These, dass der kognitive Wert eines Kunstwerks zu dessen Wert als Kunstwerk beiträgt." Maria E. Reicher, a.a.O., S. 75. Die weiteren antikognitivistischen Argumente sind: „Der Redundanzeinwand: Man kann zwar etwas von fiktionalen Werken lernen, aber es gibt keine besondere Art von Erkenntnis, die wir nur durch fiktionale Werke erlangen können. [...]Der Trivialitätseinwand: Rezipienten behaupten oft, von fiktionalen literarischen Werken etwas gelernt zu haben, können aber häufig nicht formulieren, was sie gelernt haben, und wenn sie es doch versuchen, kommen oft nur banale Allerweltweisheiten zum Vorschein, die der Komplexität der Werke in keiner Weise gerecht werden. [...] Der Einwand der fehlenden Referenz: Man kann von fiktionalen literarischen Werken nichts lernen, weil fiktionale literarische Werke sich nicht auf die reale Welt beziehen, jedenfalls nicht im behauptenden Modus." E. Reicher, a.a.O., S. 76f. (Die Enwände entlehnt Reicher von Berys Gaut, der jedoch anders als Reicher über Kunstwerke im Allgemeinen spricht. Vgl. Berys Gaut, Art and Knowledge, in: The Oxford Handbook of Aesthetics, Edited by Jerrold Levinson, Oxford 2003, S. 439-444.) Reicher positioniert sich in seinem Aufsatz an Seite des ästhetischen Kognitivismus.

${ }^{627}$ Ebd., S. 113. Die folgende Anmerkung zeigt, dass Gall den Unterschied zwischen der Literatur und der Philosophie gar nicht vergessen hat. Nicht ganz klar ist jedoch, ob er in der angemerkten Vermeidung der Verpflichtung auch seine Verpflichtung zum Im-Auge-Behalten der Inkompatibilität der Diskurse mitgemeint hat. „Die literarische Praxis ebnet mitnichten den Unterschied zwischen Philosophie und Literatur ein, sondern akzentuiert in textueller Gestalt die spannungsvolle Auseinandersetzung mit dem Problem einer möglichen Grenzziehung, ohne im Vollzug der Differenzierung von literarischem Schreiben und philosophischer Reflexion einer vorgängiger Norm, die eine solche Trennung begründet, verpflichtet zu sein." S. 112.

${ }^{628}$ Michał Januszkiewicz, 'Kosmos' Witolda Gombrowicza a problem nihilizmu europejskiego, ['Kosmos' Witold Gombrowiczs und das Problem des europäischen Nihilismus], in: Jarzębski, Jerzy(Red.) Witold Gombrowicz. Nasz współczesny. [Witold Gombrowicz. Unser Zeitgenosse], Kraków 2010, S. $462 f$. 
weit gegangen. Dem Roman wird zugeschrieben, er stelle Ansprüche der Metaphysik in Frage $^{629}$, ein Fazit, das Rationalisierung und Klarheit suggeriert, um die sich die Gombrowiczsche Literatur - man möchte sagen programmatisch - nicht kümmert.

Das Problem des Gebrauchs der philosophischen Begrifflichkeit in den literaturwissenschaftlichen Annäherungen mündet nicht selten in die Versuchung, den literarischen Text selbst als zum Teil philosophisch bedeutsam zu deuten und im Kontext philosophischer Werke zu situieren. Die Besonderheit des Falls Gombrowicz scheint die Versuchung noch zu steigern, da der polnische Schriftsteller selbst als Kenner der Philosophie galt und sich in seinem Tagebuch sowie in zahlreichen Interviews und Kommentaren zu den Fragen dieser Disziplin gern und kompetent äußerte. In seinen längeren Äußerungen lassen sich dabei sowohl präzis formulierte und philosophisch fundierte Anführungen als auch quasiphilosophische kurze Reflexionen ${ }^{630}$ finden, wobei besonders die letzteren nicht selten in Verbindung mit den konkreten Werken im Sinne einer Erklärung und/oder Einführung gebracht werden. Von solchen, mit der Philosophie unternähten ${ }^{631}$ Hilfestellung führt, wie es scheint, kein langer Weg zu der Annahme, Gombrowicz liefere mit seiner Literatur Einsichten von philosophischer Tragweite, indem er z.B. die Heideggersche Ontologie demontiere ${ }^{632}$, wie es Gall will oder die klassische Metaphysik in Frage stelle, wie es Januszkiewicz behauptet. Gern übersehen werden dabei Warnungen wie diese: „Die Literatur ist nicht dazu da, Probleme zu lösen, sie stellt Probleme. “633 oder eindeutige Bemerkungen wie jene, die ich nicht zufällig zum Motto dieses Exkurses gemacht habe: „Ich möchte als Künstler gelesen werden. Ich hasse diese allzu philosophische Erklärungen meines Schaffens.“634

Um diese Art Verwirrung zu vermeiden, reicht es meines Erachtens, die Unterschiede zwischen der (grundlegenden) Intention eines Philosophen und der eines Schriftstellers, während der interpretatorischen Arbeit im Auge zu behalten. Einleuchtend hat dies Tadeusz Kępiński reflektiert, indem er bemerkt: „Ein Philosoph trägt die epistemische Verantwortung

\footnotetext{
${ }^{629}$ Ebd., S. 464.

${ }^{630}$ Ein gutes Beispiel solcher lockeren quasi-philosophischen Äußerungen stellt das Gespräch über die Form dar, das Gombrowicz mit Dominique de Roux im Testament führt. Vgl. S. 51-67.

${ }^{631}$ Zu diesem Neologismus siehe meine Anmerkung in der Fn. 471, S. 130.

${ }^{632}$ Dabei zeigt sich aber als problematisch, wie die Art der Realität der im literarischen Werk geschaffenen Entitäten zu bestimmen wäre: „Zum einen ist es schwierig, ontologische Merkmale fiktionaler Charaktere zu benennen, die für alle Formen von literarischer Fiktion gültig sind. Zum anderen zwingt der ontologische Diskurs dazu, fiktionale Entitäten in irgendeiner Form als nicht existierend zu betrachten, was der Intuition widerspricht, dass fiktionale Entitäten als Teile der Welt des Lesers angesehen werden können." Christoph Demmerling,Íngrid Vendrell Ferran, Philosophie der Literatur. Fragen, Probleme und Perspektiven, in: Christoph Demmerling/ Íngrid Vendrell Ferran, a.a.O., S. 11.

${ }^{633}$ Witold Gombrowicz, Eine Art Testament, S. 61.

${ }^{634}$ Witold Gombrowicz, Dzieła, t.XIV, [Gesamelte Werke, B.XIV], Kraków 1997, S. 342.
} 
für seine Thesen, der philosophierende Schriftsteller braucht sich für die Grammatik der Erkenntnis nicht $\mathrm{zu}$ legitimieren, weder von dem Rezipienten noch von sich selbst: gewöhnlich handelt er ,aus Überzeugung، ““635 Das 'Sich-Ereignen’ der Wirklichkeit fungiere - Kępiński folgend - für einen Denker als Überprüfung, wobei ein Schriftsteller es zum Stoff seines Schreibens mache. Was die beiden (diskursiv) unterscheidet, nennt er die ,Dichte des Denkprozesses' und schreibt dem philosophischen Gedanken eine größere Dichte (vor allem die epistemologische) als dem literarischen Gedanken zu. ${ }^{636}$ Die ungenügende Dichte eines literarischen Philosophierens reicht nach Kępiński nicht dazu, neues Wissen hervorzubringen und zwar im Sinne ,der Überschreitung der Annäherungsgrade auf dem Weg der Erkenntnis. ${ }^{\text {“637 }}$ Literatur ist aber auf jeden Fall imstande, Probleme der Philosophie, sei es ontologischer, epistemologischer oder axiologischer Natur zu demonstrieren und zwar ohne in Antinomien zu geraten. ${ }^{638}$ Es ist möglich, denn , die literarische Äußerung ist nämlich eine Äußerung mit einer gesenkten Assertion" ${ }^{639}$, was ihr den Eindruck verleiht, dass sie sich zwischen Subjektivität und Objektivität situiert, „und sie erscheint dabei bloß als ein ,Projekt des Seins` und ein ,Projekt des Subjekts‘, sie muss also konkretisiert, vervollständigt, interpretiert im Akt der Rezeption werden.“640 Einen interessanten Gedanken erörtert im Kontext dieser Problematik Christoph Demmerling, indem er einzuschätzen sucht, inwiefern sich literarische Texte mit den Gedankenexperimenten z.B. der Philosophie vergleichen lassen. Gemeinsam wäre für beide Sprachverwendungsarten nach Demmerling, dass sie „nicht unmittelbar mit Wahrheit oder Wissen verbunden sein müssen, [um] ihren kognitiven Wert $\mathrm{zu}^{\text {“641 }}$ behalten. Literarische Texte können jedoch nicht so, wie Gedankenexperimente in der Philosophie funktionieren, ,da die Anordnung von Figuren und Situationen eine Vielzahl

\footnotetext{
${ }^{635}$ Tadeusz Kępiński, Witold Gombrowicz. Studium portretowe drugie. [Witold Gombrowicz. Das zweite Porträtstudium], Warszawa 1992, S. 79. Am Beispiel Gombrowicz' analysiert Kępiński zwei Untersuchungen, deren Autoren philosophische Deutung von Kosmos herausgearbeitet haben. ,Philosophisch' meint hier zweierlei: Erstens wurde behauptet, Gombrowicz liefere in seinem letzten Roman Erkenntnisse philosophischer Natur, zweitens sollte selbst die Annäherung an den Text philosophisch betrieben werden. Kępiński hält nichts dagegen, Gombrowicz als einen philosophierenden Autor zu lesen, als solcher ist er aber noch lange kein Philosoph. Vgl. S. 78-141.

${ }^{636} \mathrm{Vgl}$. ebd.

${ }^{637}$ Ebd., S. 80.

${ }^{638}$ Vgl. Jarzębski, Między kreacjq a interpretacjq [Zwischen Kreation und Interpretation] In: Gombrowicz filozof [Gombrowicz ein Philosoph], Kraków 1991, S. 187.

${ }^{639}$ Ebd., S.188. [„,wypowiedź literacka jest bowiem wypowiedzia o obniżonej asercji”]

${ }^{640}$ Ebd.

${ }^{641}$ Christoph Demmerling,Íngrid Vendrell Ferran, Philosophie der Literatur. Fragen, Probleme und Perspektiven, in: Christoph Demmerling/ Íngrid Vendrell Ferran, a.a.O., S. 18.
} 
von Aspekten umfassen und komplexer sind als die in der Regel eindimensionalen Szenarien, mit denen wissenschaftliche oder philosophische Gedankenexperimente aufwarten.“642

Zu Recht, wie ich meine, bemerkt Kępiński, dass die Lektüre von Kosmos keineswegs das Wissen über die Welt erweitere ${ }^{643}$, somit vermag sie es auch nicht, philosophische Ideen zu ergänzen oder gar zu überwinden. Was affirmativ-entladend zu wirken sucht, kann auch nicht gleichzeitig kontemplativ-rationalisierend sein. Nichtsdestotrotz wirkt Literatur nicht selten als eine Art ,erkenntnisschöpfender Stimulator', der die Prozesse der philosophischen Reflexion in Gang zu setzen vermag. ${ }^{644}$

\footnotetext{
${ }^{642} \mathrm{Ebd}$

${ }^{643}$ Vgl. Tadeusz Kępiński, a.a.O., S. 140.

${ }^{644}$ Vgl.ebd., S. 80.
} 


\section{Fazit}

„Vorbei ist die Zeit des gewöhnlichen Lesens.“

W. Gombrowicz

Die vorliegende Dissertation suchte Textstrategien zu lokalisieren und zu beschreiben, die Rezipienten postmoderner Prosa zum Zustand der Desorientierung führen, d.h. zu dem Punkt im Verlauf der Lektüre eines literarischen Werkes, an dem der Leser nicht (mehr) fähig ist, den Sinn der Textausschnitte und die sinnstiftenden Beziehungen zwischen ihnen (auch im Hinblick auf das Textganze) diskursiv $\mathrm{zu}$ konstituieren (hervorzubringen). Die Desorientierung kam jeweils zustande als Folge der Anhäufung von Irritationen und Verwirrungen, die die Lektüre in erster Linie punktuell stören. Der desorientierte Leser sieht sich folglich vor die Notwendigkeit gestellt, seine Erkenntniserwartungen in Frage zu stellen und die ihm vertrauten Strategien der Sinnstiftung zu hinterfragen. In drei Romanen versuchte ich Textstellen zu lokalisieren, an denen der Sinn aufhört, diskursiv eindeutig deutbar, decodierbar oder erklärbar zu sein. Die Untersuchung sollte zur Findung der auf die Desorientierung zielenden Textstrategien führen.

Die Desorientierung wird im Allgemeinen ontologisch (fragend nach dem, Was') und/oder epistemologisch (fragend nach dem ,Wie') fundiert, d.h. der Rezipient wird mit Unklarheiten konfrontiert, welcher Art Entitäten die Protagonisten begegnen und auf welchen Wegen sie zur Erkenntnis kommen (können). Sowohl ontologische als auch epistemologische Momente weisen darüber hinaus ein spezifisches Insistieren auf das Vorhandensein einer Realität, einer Dimension auf, bei gleichzeitiger explizit thematisierter Unmöglichkeit der literarischen Inszenierung dieser (de facto literarästhetisch undarstellbaren) Realität. Der Prozess des Desorientiert-Werdens müsste daher - so meine Behauptung - etwas mit der Steigerung der Ästhetisierungsintensität gemeinsam haben, d.h. mit dem Multiplizieren der (potentiell bedeutungsvollen) Beziehungen zwischen den Textkonstituenten. Diese Steigerung ließe sich mit dem Prozess der Entgrenzung der Ästhetik beschreiben und sie gehört m.E. zu den wichtigsten Merkmalen der Postmoderne. Diese auf den ersten Blick sich bloß auf der Oberfläche vollziehende Ästhetisierung reiche beim genauen Hinsehen, wie uns der bekannte Affirmator der ,Aktualität des Ästhetischen“ Wolfgang Welsch zu belehren sucht, bis zur „Ästhetisierung unserer Erkenntnis- und Wirklichkeitskategorien einschließlich der Kategorie 
Wahrheit.“645 Die Komplexität und die Permanenz der Entgrenzung der Ästhetik müssen daher sowohl horizontal als auch vertikal gesichtet werden. Die Oberflächenästhetisierung bedeutet „soviel wie Ausstattung der Wirklichkeit mit ästhetischen Elementen, Überzuckerung des Realen mit ästhetischem Flair.“646 Bereits hier macht sich der von Welsch betonte Doppelcharakter der Ästhetik bemerkbar:

„Denn die aisthesis hat zwei Seiten; sie ist durch eine Gabelung von Empfindung einerseits und Wahrnehmung andererseits charakterisiert. Die Empfindung ist lustbezogen und gefühlshaft, die Wahrnehmung hingegen ist gegenstandsbezogen und erkenntnisartig. Subjektive Bewertung bildet den Fokus der Empfindung, objektive Feststellung den Skopus der Wahrnehmung. Dieser Gabelung entsprechend kann >ästhetisch< im Blick auf den Lustakzent der Empfindung eine hedonistische und im Blick auf die Betrachtungshaltung der Wahrnehmung eine theoretizistische Bedeutung annehmen. “647

Eine spezifische Ästhetisierung der Wahrnehmung könnte dann den ersten Moment der sich vollziehenden Entgrenzung des Ästhetischen markieren. Welsch kompliziert jedoch seine Ausführungen, indem er nicht jede Wahrnehmung als ästhetisch einstufen will:

„Wenn wir eine Wahrnehmung als >ästhetisch< bezeichnen, so haben wir nicht die gewöhnliche Art des Wahrnehmens im Sinn, sondern eine besondere und höherstufige Wahrnehmung, die sich auf spezifische Aspekte und Gegenstände richtet [...] Diese ästhetische Wahrnehmung bezieht sich generell weniger auf Elemente als auf Verhältnisse von Elementen: auf Zusammenhänge und Kontraste, Harmonien und Korrespondenzen, Gegenführungen oder Analogien. Die ästhetische Wahrnehmung ist an deren Stimmigkeit und Gelungensein interessiert. Fragen der Form und der Proportion bilden ihre Domäne.“648

Die Schwierigkeit dieser Ausgrenzung liegt meines Erachtens jedoch in der Inkonsequenz, die hier zum Vorschein kommt, wenn man, wie es Welsch tut, die Ästhetisierung aller Wahrnehmungsschichten verkündet. Jede (Art) Wahrnehmung müsste dann einfach mehr oder weniger ästhetisch sein, d.h. mehr oder weniger intensiv (je nach ihrer Komplexität)

\footnotetext{
${ }^{645}$ Wolfgang Welsch, Grenzgänge der Ästhetik, Stuttgart 1996, S. 45.

${ }^{646}$ Ebd., S. 11.

${ }^{647}$ Ebd., S. 26.

${ }^{648}$ Ebd., S. 28. „Wo sich >ästhetisch< auf solche Wahrnehmungen bezieht, rückt daher ein form - und proportionenbezogenes Bedeutungselement in den Vordergrund. Zusätzlich ist für solche Wahrnehmung ein theoretizistisches Bedeutungselement kennzeichnend: die ästhetische Wahrnehmung hat die Vollzugsform der Betrachtung. Am unmittelbaren Sein der Dinge ist sie ohnehin nicht interessiert, und noch ihre eigentümlichen Gegenstände genießt sie auf Distanz - eben in der Weise der Betrachtung. Die ästhetische Wahrnehmung ist nicht praxisorientiert, sondern kontemplativ, nicht pragmatisch, sondern theoretizistisch." Da die Grenzen zwischen einer nicht-ästhetischen und ästhetischen Wahrnehmung, wie sie Welsch sehen möchte, fließend bleiben, scheint mir diese Ausgrenzung kaum nachvollziehbar und wenig fruchtbar zu sein.
} 
perzipiert werden. Die Wahrnehmungen würden sich dann bloß durch ihre Intensität voneinander unterscheiden.

Die zentrale Schwierigkeit der Argumentationslogik, die Welsch verfolgt, betrifft jedoch seine Behauptung, Ästhetik sei „nicht [mehr - K.S.] Vehikel, sondern [sei] zur Essenz geworden“649, „gehört also nicht mehr bloß zum Überbau, sondern zur Basis.“650 Was Welsch dabei als Vermächtnis der Moderne verkündet und begrüßt, ist die Prinzipialisierung, Universalisierung und die epistemologische Fundamentalisierung des Ästhetischen ${ }^{651}$ :

„Immer mehr drängt sich der Gedanke auf, dass ästhetische Kategorien zum Verständnis schon elementaren und allgemeinen Wirklichkeitsverfassung geeignet sein könnten. An die Stelle der klassischen ontologischen Kategorien von Sein, Wirklichkeit, Beständigkeit, Realität usw. treten jetzt ästhetische Zustandskategorien wie Schein, Beweglichkeit, Bodenlosigkeit und Schweben. [...] Insofern wohnt jedem Urteil ein ästhetischer Akt inne. Somit entspricht das ästhetische Urteil nicht nur der reinen Grundform eines jeden Urteils, sondern davon gilt sogar die Umkehrung: jegliches Urteil schließt einen ästhetischen Vollzug ein. [...] Unsere Erkenntnis ist sowohl in ihrer propositionalen Verfassung wie in ihrem kommunikativen Charakter ästhetisch bedingt. “652

Es liegt auf der Hand, dass die von Welsch affirmierten ,ästhetischen Fundamente allen Erkennens, [die] prinzipielle Protoästhetik der Kognition“653 im Grunde nicht mehr als eine permanente Entgrenzung des Ästhetischen schönzureden suchen, eine Aktualität der Ästhetik begrüßen, die meines Erachtens zu Recht als eine falsche Aktualität in Frage gestellt wurde. ${ }^{654}$ Eine derartige Entgrenzung muss und kann jedenfalls nicht in alle Bereiche eindringen, die einst als nicht ästhetische galten:

„Gewiß haben beide, Kunst und Theorie, Momente des je anderen an sich, aber der Kern ästhetischer Erfahrung ist nicht-diskursiv, so wie der Kern eines Arguments nicht rhetorischpersuasiv ist. Verwischt man die Grenzen, so geht nicht nur die Präzision des Denkens verloren

\footnotetext{
${ }^{649}$ Ebd., S. 14.

${ }^{650}$ Ebd., S. 15.

${ }^{651}$ Vgl. ebd., S. 53 u. 71.

${ }^{652}$ Ebd., S. 71 u. 78. Die epistemologische Ästhetisierung sollte „den eigentlichen Untergrund der aktuellen Ästhetisierungsprozesse“ bilden, die in allen Lebensbereichen verlaufen: „erstens die verhübschende Oberflächenästhetisierung des Alltags, zweitens die tiefergehende, technologisch und medial bedingte Ästhetisierung unserer materiellen wie sozialen Wirklichkeit, drittens die ebenso tiefreichende Ästhetisierung unserer lebenspraktischen Einstellungen und moralischen Orientierungen [...] “ Ebd., S. 54f.

${ }^{653}$ Ebd., S. 46.

${ }^{654}$ Eine falsche Aktualität des Ästhetischen diagnostiziert Karl Heinz Bohrer im Buch Die Grenzen des Ästhetischen, München Wien, 1998, S. 171f. Er macht dabei darauf aufmerksam, wie radikal sich verschiedene Auffassungen der Ästhetik voneinander unterscheiden.
} 
und seine Beziehung zur Sache, sondern auch die spezifische Intensität der ästhetischen Erfahrung - beide werden schmierig und gefühlig. “655

Aus guten Gründen, wie man sieht, müssen also der ohnehin in der Postmoderne weit fortgeschrittenen Entgrenzung Grenzen gesetzt werden, sonst müssten wir uns bald in einer Wirklichkeit abfinden, in der nur noch Ästhetisches da wäre und zwar in allen Existenz- und Wahrnehmungsschichten. Als besonders umstritten muss in dieser Hinsicht auch die Konzeption des ,ästhetischen Denkens“ erscheinen, in dem das Ästhetische „nicht bloß Gegenstand der Reflexion [sei], sondern den Kern des Denkens selbst betreffen“656 wird. Das ästhetische Denken sollte begriffliches Denken ergänzen bzw. ersetzen, weil es ,gegenwärtig das eigentlich realistische ist. [...] Denn es allein vermag einer Wirklichkeit, die - wie die unsrige - wesentlich ästhetisch konstituiert ist, noch einigermaßen beizukommen. ${ }^{\text {“657 Dem }}$ ästhetischen Denken schreibt Welsch die Erkenntniskompetenz, die Fähigkeit, Diagnosen zu stellen sowie orientierend zu wirken, $\mathrm{zu} .{ }^{658}$

Nochmals wird also versucht, das Denken seines Fundaments, d.h. der Diskursivität zu berauben, eine Strategie, die meines Erachtens den Dissens bloß um des Dissenses willen stärkt und gegen jeden Versuch einer Konsensbildung resistent macht. Was im Endeffekt entsteht, sind unzählige Inseln inkompatibler Sinnhaftigkeiten, die rhetorischen Eruptionen, die im Spiel der sprachlichen Überbietungen sich in ihren bloßen Entladungen erschöpfen. Bereits angesichts dieser Zwischenbilanz sehe ich die Notwendigkeit einer Grenzziehung als ausreichend begründet:

„Je reiner der ästhetische Kern erhalten ist, umso größer die Strahlkraft nach außen: diese geschieht allerdings nicht als sozialkritische Korrektur des generellen Diskurses, sondern vielmehr als dessen Irritation. [...] die Irritation des Diskurses vollzieht sich nämlich als Subversion der Gültigkeit seiner normativen Begriffe. Gerade weil der generelle Diskurs selbst [...] keine ästhetischen Elemente besitzt - sofern er solche besitzt, verändert er sich nach Maßgabe der Komplexität solcher Elemente sofort zur poetischen Rede, weil also der Diskurs aästhetisch ist, kann die ästhetische Subjektivität subversiv auf ihn zurückwirken.“659

\footnotetext{
${ }^{655}$ Rudolf Burger, Das Denken der Postmoderne. Würdigung einer Philosophie für Damen und Herren, in: Albert Berger, Gerda Elisabeth Moser (Hg.), Jenseits des Diskurses. Literatur und Sprache in der Postmoderne. S. 37.

${ }^{656}$ Wolfgang Welsch, Ästhetisches Denken, Stuttgart 1990, S. 46. „Ästhetisches Denken ist eines, für das Wahrnehmungen auschlaggebend sind. Und zwar sowohl als Inspirationsquelle wie als Leit- und Vollzugsmedium."

${ }^{657}$ Ebd., S. 57.

${ }^{658} \mathrm{Vgl}$. ebd.

${ }^{659}$ Karl Heinz Bohrer, a.a.O., S. 188.
} 
Was Bohrer einleuchtend betont, ist die Einsicht, dass die Entgrenzung des Ästhetischen nur auf Kosten desselben betrieben werden könne ${ }^{660}$, indem seine subversive und zugleich differenzierende Kraft geschwächt werde und „das enigmatisch-elitäre Moment des eigentlich Ästhetischen immer mehr abhanden" ${ }^{\text {6661 }}$ komme.

Was Welsch verkündet und wofür er sich offen einsetzt, fand bereits seinen Ausdruck in der postmodernen Literatur. Teils mit großem, teils mit mangelndem Raffinement versuchen SchriftstellerInnen, die der Nachmoderne zugeschrieben werden können, der höchst ästhetisierten Wirklichkeit, der tobenden Entgrenzung der Ästhetik also, literarischen Ausdruck zu geben. Wie stark sie dabei die Diskursivität, den Kern des begrifflichen Denkens herausfordern, versuchte ich eben in dieser Dissertation zu untersuchen.

Jede durch die Lektüre der von mir untersuchten Romane verursachte Desorientierung hat ihre Quelle in der Entgrenzung der Ästhetik, die sich grob genommen zu einer Strategie des Sinnentzugs bzw. Sinnverknappung entfaltete. Der Leser wird wiederholt mit einem Versprechen eines zu entdeckenden Sinns getäuscht und was er dagegen wahrnimmt, ist die allmählich zunehmende Entdifferenzierung der Ereignisse. Irgendwann im Laufe der Lektüre wird er mit dem Dilemma konfrontiert, die Bedeutung des Romangeschehens diskursiv nicht mehr nachvollziehen zu können. Dieser Moment markiert auch das Verlieren oder das Destabilisieren jeglicher Orientierungspunkte. Im Einzelnen wird die Entgrenzung des Ästhetischen und die ihr entspringende Entdifferenzierung unterschiedlich komplex inszeniert. Die Perzeption des Lesers wird z.B. mit Unmengen von Signifikanten überflutet, zu denen er vergeblich nach passenden Signifikaten sucht. Die Erzählung der Ereignisse und Gestaltung der Figuren werden oft unterbrochen, gehemmt, aufgehoben, nicht zu Ende gebracht/erzählt, so dass die Konstituierung der Gesamtbedeutung permanent unterlaufen wird. Obwohl alle Geschichten linear erzählt sind, scheint es unmöglich zu sein, irgendetwas in ihnen als sichere Erkenntnis $\mathrm{zu}$ gewinnen, da das permanente Stören des Signifikationsprozesses den Leser mit einem Minimum eines Sinns/einer Sinnhaftigkeit zurücklässt. Die Ästhetik der Desorientierung ließe sich somit als eine Ästhetik der Entdifferenzierung der Geschehensmomente, d.h. der Steigerung der Wahrscheinlichkeit ihrer Gleichwertigkeit für die Bedeutungskonstituierung beschreiben; Wiederholt geweckt wird der Eindruck, dass es sich hier um etwas Bedeutungsvolles handelt, dessen Bestimmen sich jedoch konsequent als unerreichbar erweist. Durch die Entdifferenzierung wird die Bedeutung zerstreut und sie kann sich hinter vielen möglichen Zeichen und Symbolen verstecken.

\footnotetext{
${ }^{660}$ Ebd., S. 178.

${ }^{661}$ Ebd., S. 172.
} 
Die Postmoderne (Literatur) lockert mit der (Entgrenzung der) Ästhetik die Diskursivität und zwar bis zu dem Punkt, an dem diese ihre Funktion verliert, indem sie ihre Rolle des Hinführens zur Sinnstiftung nicht mehr zu erfüllen vermag. Was damit erreicht ist, ist ein Zustand der fortgeschrittenen Entropie, in der unterschiedliche Deutungen als gleich plausibel und gleich adäquat erscheinen. Es scheint tatsächlich richtig zu sein, postmoderne Literatur als eine gegen den ,Sinnterror' immunisierte zu betrachten und zwar in dem Sinne, dass man in ihr vergeblich nach einer zu entdeckenden Botschaft Ausschau hält. ${ }^{662}$

Ist die Quelle der Desorientierung im postmodernen Roman generell in der Entgrenzung des Ästhetischen zu situieren, so werden die Desorientierungsstrategien im Einzelnen unterschiedlich eingesetzt und entfaltet. Was sich dabei gut beobachten lässt, ist der Fortschritt der Entgrenzung. In dieser Hinsicht ließe sich Elfriede Jelineks Lust als am weitesten ästhetisch entgrenzt einstufen, in Witold Gombrowicz ${ }^{6}$ Kosmos ist dagegen dieses spezifische Phänomen am wenigsten fortgeschritten.

Jelineks sehr gekonnt inszeniertes Entgrenzen entspringt vor allen Dingen der stark hervorgehobenen ,Seichtheit" und der nahezu a-psychologischen Konzipierung der Romanprotagonisten, die die österreichische Schriftstellerin zu Hauptcharakteristika ihrer Prosa gemacht hat. Die Figuren Jelineks lassen sich als zu einem ,tiefenlose[n] OberflächenEs [...] mit einem neuen Typ von Emotionalität, [d.i. zu den] frei flottierenden personalen Intensitäten“ ${ }^{663}$ degradierte beschreiben und als solche, zu bloßen Körpern reduzierte, bewegen sich chaotisch von den Höhepunkten der sinnlichen Genüsse bis zu den Tiefpunkten körperlichen Leidens. Als Effekt dieser Strategie wirken die Charaktere und „das konkret Schreckliche [...] seltsam ausgehöhlt, flach. Da alles ausgesprochen wird, das Zeichen tendenziell mit dem Bezeichneten zusammenfällt, kann sich kein Hinweis auf verborgene Bedeutsamkeit [...] einstellen. “664 Mit ihrem Antiporno-Roman, zu dem Lust werden sollte, schuf Jelinek ein Werk, das mit wechselnden Intensitäten die Lektüre von harmlosen Irritationen über sich zunehmend häufende Verwirrungen bis hin zur Desorientierung führt.

„Einen ganzen Fundus an Soziolekten, Jargons, Versatzstücken aus Werbung, Comic, Weltbetrachtung und Natur führt Elfriede Jelinek auf, um in Lust [...] [mehrere - K.S.]

\footnotetext{
${ }^{662}$ Vgl., Wendelin Schmidt-Dengler, Werner Kofler in: Albert Berger, Gerda Elisabeth Moser (Hg.), a.a.O., S. 298.

${ }^{663}$ Gabriele Schwab, Entgrenzungen und Entgrenzungsmythen: zur Subjektivität im modernen Roman; Daniel Defoe, Herman Melville, Virginia Woolf, James Joyce, Samuel Beckett, Thomas Pynchon, Stuttgart 1987, S. 18.

${ }^{664}$ Günther A. Höfler, "Stop making sense". Werner Schwabs Pop-Stück, Mesalliance aber wir ficken uns prächtig'-ein postmodernes Volksstück? in: Albert Berger, Gerda Elisabeth Moser (Hg.), a.a.O., S. 334.
} 
Kopulationen so über die Runden zu bringen, daß Leseneulingen in jedem Fall schlecht und den

Lesern als postmodern-abgeklärten Zynikern keineswegs langweilig werden kann.“665

Dem thematisch-rhetorischen Patchwork wird zusätzlich ein assoziatives Delirium ${ }^{666}$ beigemischt, das die Narration unnatürlich dynamisiert, die Zeichen nach einem undecodierbaren Muster multipliziert und das Gedächtnisvermögen des Lesers durch unzählige Abschweifungen herausfordert. Lust zielt konsequent auf permanente Störung, indem der Rezipient zur Re-Orientierung der herkömmlichen Leseeinstellung gezwungen wird. Der Schreibgestus des ständigen Entziehens der sinnhaftigkeitsstiftenden Tiefenschicht sucht den Leser zu einem Jäger umzuwandeln, der in der undurchschaubarer Fülle der Zeichen und Symbole diejenigen aufzuspüren und zu erjagen versucht, die den Hunger der Gesamtbedeutung zu stillen vermögen. Die chaotische Verschachtelung von Daten, Berichten und Kommentaren wird mit großer Wahrscheinlichhkeit das Gedächtnis des Lesers bis zum Erschöpfen bringen. Das wahre Desorientierungspotenzial entfaltet sich jedoch in meiner Überzeugung im Kontext der im Sexuellen situierten Dialektik der Lust, die in einer provozierend krassen Art und Weise zum Ausdruck kommt.

Möchte man irgendwann im Laufe der Lektüre auf die vergebliche Mühe der plausiblen Verknüpfung der rezipierten Passagen verzichten, entscheidet man sich also dafür, der Fülle der Abschweifungen weniger Aufmerksamkeit zu schenken, dann bleibt nur noch Sex und zwar in der Form einer verzerrten Pornografie versprachlicht, die (allem Anschein nach) strategisch konzipiert wurde. Hat Jelinek etwa hinter der unterlaufenden Verzerrung des Pornografischen die verwirrende Logik der Lust zu chiffrieren gesucht? Tatsächlich hat sie es versucht „den Blick auf das Obszöne [...] aus weiblicher Sicht zu zeigen“6667, wie sie selbst gesteht, was sie aber noch gesteht, ist das Fiasko dieses Unterfangens. ${ }^{668}$ Was erzählt dann wirklich der Roman Lust, wenn nicht das, was seine Autorin beabsichtigt hat? Welche Lust um genauer zu fragen - fand in Lust ihren Ausdruck? Der Hinweis Ina Hartwigs, in Lust fehle „eines der entscheidenden pornographischen Sujets [...]: nämlich die Lust der Frau“6669 konnte ich jedenfalls, wie bereits erwähnt, nicht bestätigen. ${ }^{670}$ Sowohl die zwei involvierten männlichen Figuren als auch die Protagonistin werden mehrmals von der Lust ergriffen, was

\footnotetext{
${ }^{665}$ Gerda Elisabeth Moser, Die Funktion der Sprache in der österreichischen postmodernen Literatur, in: Albert Berger, Gerda Elisabeth Moser (Hg.), a.a.O., S. 243.

${ }^{666}$ Wendelin Schmidt-Dengler, a.a.O., S. 302. Diese sehr zutreffende Bezeichnung charakterisiert m.E. sehr gut Jelineks Schreibweise. Hier betrifft sie aber Texte Werner Koflers.

${ }^{667}$ Vgl. S. 104.

${ }^{668}$ Vgl. ebd.

669 Ina Hartwig, Sexuelle Poetik. Proust Musil Genet Jelinek, Frankfurt am Main 1998, S. 247.

${ }^{670} \mathrm{Vgl}$. die entsprechenden Romanstellen, in denen sich die Lust-Protagonistin in der Affäre mit dem Studenten Michael verliert, zit. z.B. auf S. $119 f$.
} 
jedoch nicht heißt, dass alle auch ihre Kosten kommen. Es ist offensichtlich, dass Gerti ihre Lust nicht so befriedigen kann, wie es Hermann und Michael vermögen. Es bleibt aber völlig im Dunkeln, inwieweit sich Gertis Lust von der der sie misshandelnden Männer unterscheiden sollte. In dieser Unklarheit oder genauer gesagt in Versuchen, sie aufzulösen, situierte ich eben die spezifische Hyper-Subversion des Jelinekschen Romans und ihr Desorientierungspotential. Das Novum des hyper-subversiven Wirkens bestünde meines Erachtens in dem Unterfangen, Momente des spezifisch Männlichen mit Momenten des spezifisch Weiblichen in einen Konflikt zu bringen, bei gleichzeitiger Unmöglichkeit, dem Weiblichen diskursiv gesonderte Züge geben zu können.

Die postulierte, imaginäre Grenze des männlichen Diskurses, die Jelinek intensiv zu (er)finden versuchte, um diese zu überschreiten, konnte sie nicht hervorbringen. Selbst die krasseste Verzerrung des männlichen Blicks auf das Obszöne, Subversion dessen „mittels einer gedanklich und sprachlich purzelbaumschlagenden écriture "671, konnte das genuin Weibliche nicht kreieren, der weiblichen Lust wurde keine gesonderte Form zugeschrieben. Das höchst aggressiv betriebene Unterlaufen des männlichen Diskurses führte zu keiner ,tieferen Wahrheit', jede (potenzielle) Tiefe schien auf der Textoberfläche aufgelöst zu werden. ${ }^{672}$ Der ums Dechiffrieren der scheinbar ,zwischen den Worten“ versteckten LustDialektik bemühte Leser wird mit Fragen konfrontiert, auf die er in Lust keinerlei Antworten findet: Wie vermochte sich Gertis Lust in Verbindung mit Michaels Lust zu entfachen, mit einer Lust, die auf die gleiche Art und Weise Gertis Ehemann in sich zu entfachen weiß? Wie verhält es sich wirklich mit Gertis Lust, denn „eure Lust bleibt immer dieselbe! Sie ist eine endlose Kette von Wiederholungen, die uns mit jedem Mal weniger gefallen, weil wir durch die elektronischen Medien und Melodien daran gewöhnt wurden jeden Tag etwas Neues ins Haus geliefert zu kriegen.“ (L, 123) Könnte es etwa in der Art eines (unbewussten) Ausrutschers der Autorin passieren, dass sie ihre Protagonistin an der falschen, nach einer männlichen Libido-Ökonomie vorprogrammierten ${ }^{673}$ Lust teilhaben ließ, obwohl sie doch um den weiblichen Blick auf Lust bemüht war? Oder ist das alles ironisch gemeint? Oder ist es letztendlich die Sprache, die versagt hat, denn ,jetzt sprechen allein die Sinne, doch wir verstehen sie nicht, denn sie haben sich unter unserer Sitzfläche in etwas Unbegreifliches verwandelt.“ (L, 114) Zweimal wird der Leser daher daran erinnert, dass es Erfahrungen gibt, für die noch keine Worte erfunden wurden, und jene vermochte auch Jelinek nicht zu

\footnotetext{
${ }^{671}$ Neva Šlibar, Anschreiben gegen das Schweigen. Robert Schindel, Ruth Klüger, die Postmoderne und die Vergangenheitsbewältigung, in: Albert Berger, Gerda Elisabeth Moser (Hg.), a.a.O., S. 348.

${ }^{672}$ Vgl. Bogdan Baran, Postmodernizm i końce wieku, inter esse, Kraków 2003, S. 189.

${ }^{673}$ Vgl. Luce Irigaray, Genealogie der Geschlechter, Freiburg 1989, S. 45.
} 
erfinden. Das „Heranschreiben an das Unaussprechbare“ ${ }^{674}$ musste scheitern und zur logischen Konsequenz dieses Scheiterns wird die Unmöglichkeit, Lust zu einem sinnhaften Ganzen deuten zu können. Allmählich konnte sich Jelinek während des Schreibens dessen bewusst werden, dass sie Undarstellbares zu versprachlichen sucht, genauso Schritt für Schritt kann sich auch der Lust-Rezipient dessen bewusst werden, dass seine Bedeutungssuche vielleicht in die Desorientierung mündet.

Anders als Lust versucht Gombrowicz' Kosmos die Reste einer Tiefe - vergeblich, wie sich am Ende des Romans zeigt - zu retten. In dieser Hinsicht ist meines Erachtens der letzte Roman des polnischen Schriftstellers auf dem Weg von der Moderne zur Postmoderne zu situieren. Die schrittweise Auflösung der Tiefenschicht der Erzähleridentität wird dadurch vollzogen, dass die ,Wahrnehmungs-Assoziations-Logik‘ und die ,Ordnungslogik ‘ sich als miteinander permanent konfligierende erweisen. Im Endeffekt müssen (um einer Katastrophe vorzubeugen ${ }^{675}$ ) alle Versuche einer Einigung verworfen werden, indem die Aufmerksamkeit an der Oberfläche fixiert wird, letztendlich an der Textoberfläche, wo das Verschwinden der Interpunktion $^{676}$ jegliche Ordnungs- und Hierarchisierungsversuche zunichtemacht. Anders als in Lust wird sich somit in Kosmos die Entgrenzung des Ästhetischen eher allmählich vollziehen und ihren Effekt hat m.E. treffend der von mir in dieser Frage bereits zitierte Markowski auf den Punkt gebracht: „[...] die Sinnstruktur ist bei Gombrowicz eine horizontale und nicht eine vertikale. Das bedeutet, dass der Sinn nicht versteckt ist, unter der Oberfläche der Dinge und Ereignisse verborgen, wie bei Freud, sondern entsteht als Effekt der Beziehungen zwischen ihnen." ${ }^{, 677}$ Markowski entdeckt hier und thematisiert - um es nochmals zu betonen - eine Textstrategie, deren Einsatz dem Leser die Veränderung seiner üblichen Leseeinstellung abverlangt. Der Sinn darf jetzt grundsätzlich dem gegebenen ,Sprachmaterial“ entnommen werden, die Interpretation darf sich ausschließlich aus den ,Kombinationen“ von gegebenen Zeichen ergeben. Ich würde, wie bereits erwähnt, an dieser Stelle die These riskieren, diese horizontale Sinnstruktur gehört zu den wichtigsten Charakteristika der postmodernen Literatur. Sie entsteht als Effekt einer zunehmenden Ästhetisierung, d.h. sie wird inszeniert in mehr oder weniger intensiver und exzessiver Affirmation der (Text)Oberfläche. Jelineks Lust wäre in der Hinsicht ein Beispiel einer höchst exzessiven

\footnotetext{
${ }^{674}$ Neva Šlibar, a.a.O., S. 348.

${ }^{675}$ Würde Witold seine Assoziationslogik weiter verfolgen, müsste er Lena umbringen.

${ }^{676}$ Eine treffende Interpretation dieses Schwindens liefert Michał Okłot. Vgl. Zit. 586, S. 168.

${ }^{677}$ Michał Paweł Markowski, Czarny nurt Gombrowicz, świat, literatura. [Die schwarze Strömung Gombrowicz, Welt, Literatur] Kraków 2004, S. 149.
} 
Affirmation der Oberfläche, Gombrowicz‘ Kosmos ist dagegen ein Beispiel einer eher subtil tastenden Form dieser Affirmation.

Das bloße Verschieben der sinnhaftigkeitsbildenden Schicht an die Oberfläche erledigt jedoch mitnichten das Problem der Bedeutungsbildung in postmodernen Texten. Die raffiniertere Literatur der Nachmoderne weiß das Vorhandensein einer Tiefendimension geschickt und trickreich vorzutäuschen und dadurch ihr Verwirrungspotential wesentlich zu stärken. Es sind vor allen Dingen Momente des unerwarteten Eindringens einer kaum darstellbaren ,Realität ${ }^{678}$, mit denen Kosmos explizit und implizit durchtränkt ist und die den Leser nach einer unter dem Versprachlichten versteckten Sinnschicht suchen lassen. All diese Momente empfindet der Erzähler als bedrückend, lähmend, unheimlich, und sie können entweder als Neuformierung oder als bloßer Zerfall der Wirklichkeit gedeutet werden. Die punktuell erscheinenden Unheimlichkeiten bei gleichzeitiger Reduktion der Tiefendimension bergen in sich meines Erachtens das größte Desorientierungspotential des Romans. Das Unheimliche in Kosmos verliert allmählich seinen Bezug auf irgendeinen verdrängten Inhalt ${ }^{679}$ und entfaltet sich zum Unheimlichen, das aus dem plötzlichen, völlig unerwarteten Manifest-Werden von Elementen ${ }^{680}$ hervorgeht. Dieses plötzliche Aus-dem-ZusammenhangGerissen-Sein beraubt das Manifest-Gewordene seines natürlichen Sinns und macht es in dem Moment unbegreiflich. Der Leser muss es aber als geheimnisvoll wahrnehmen und sucht das Rätsel des Manifest-Werdens zu lösen. Das Unsinnig-Gewordene entzieht sich aber konsequent dem Sinnhaft-Werden und unterläuft somit ständig die Signifikationsprozesse. Der Leser wird es nicht akzeptieren wollen, dass Erdklümpchen, Steine, Wurzel und Erde auf nichts verweisen, dass sie bloß für den Erzähler manifest geworden sind, was sie früher nicht waren, und dass sich in diesem Manifest-Werden ihren Sinn erschöpft. Dieses Auf-NichtsVerweisen unterläuft zusätzlich den Assoziationswahn des Erzählers, indem die irrsinnig geknüpften Verweise doch als Verweise anerkannt werden müssen. Das Fokussieren der Münder, ihr assoziatives Verknüpfen mit dem Hängen, dem Stäbchen, der Selbstigkeit wird keine logische Rechtfertigung finden, es wird aber im Kontext der Assoziations(para)logik Witolds nachvollziehbar. Das punktuelle ,Eindringen dessen da draußen“, d.h. das ManifestWerden des bis jetzt Nicht-Manifesten beraubt dagegen den Erzähler allmählich der Heimlichkeit und der Selbstverständlichkeit der gewohnten Beziehungen. Das Verwirrende ergibt sich dabei aus dem daraus resultierenden ,fürchterliche[n] Doppelsehen, das sich als

\footnotetext{
${ }^{678}$ Siehe z.B. S. $159 f$.

${ }^{679}$ Die typischen, ,verdrängungsartigen' Unheimlichkeiten kommen ebenfalls in Kosmos zum Zuge. Sie werden auch direkt als unheimliche benannt, wie im Beispiel des unheimlich wirkenden Mundes Katasias. Vgl. K, S. $19 \mathrm{f}$.

${ }^{680}$ Siehe dazu die entsprechende Kosmos-Passage, S. $161 \mathrm{f}$.
} 
Riss in der Wirklichkeit empfinde.“681 Dieses kaum erträgliche Gefühl, das jeden Versuch, zu einer sicheren Erkenntnis zu gelangen, unterläuft, wird der Kosmos-Leser mehrmals erfahren müssen. Die undurschaubare Dialektik des momentanen Eindringens des Kosmos in die heimliche Umwelt hat meines Erachtens noch einen weiteren destruierenden Effekt, sie destabilisiert nämlich zunehmend die Wahrnehmungsprozesse des Protagonisten. Die verwirrende Verflechtung von Äußerungen des erlebenden und des korrigierendkommentierenden Erzählers zeugt davon, dass immer irrsinnigere Kombinationen von Verweisen hervorgebracht werden und zu einer quasi paranoiden Realitätswahrnehmung führen. Hier lauert auch die Falle der Allsinnhaftigkeit, in der jedes wahrgenommene Element mit einem anderem nach Belieben verknüpft werden und in eine beliebige Deutung münden kann.

Einen erheblichen Fortschritt der Entgrenzung des Ästhetischen markieren darüber hinaus der Greb-Dialog und das Ritual des Grebebsens. Das Wort (Greb), das keine Bedeutung hat und somit keine intersubjektiv nachvollziehbare Assoziationen wecken kann, kann nur noch an der Textoberfläche als Zeichen mit einem suspendierten Sinn beobachtet werden. Nur provisorisch kann Greb etwas bedeuten, nur seine Situierung zwischen anderen Worten und seine Bewegungen zwischen den Kontexten lassen dem Wort sehr vage Bedeutungen zuschreiben und seine Rolle für das Geschehen genauso vage einschätzen. Die Erfahrungen des ,Eindringens dessen da draußen“ sowie das Spiel mit dem Greb betonen - in meiner Überzegung - die zunehmende Sensibilisierung für das Oberflächliche und führen schrittweise zur Fixierung der Aufmerksamkeit an der Textoberfläche. Das bereits erwähnte Schwinden der Interpunktion auf der letzten Seite des Romans könnte als eine der möglichen (literarästhetischen) Endstationen der Entgrenzung der Ästhetik verstanden werden, in der ein Maximum an Entdifferenzierung erreicht worden wäre und folglich eine Desorientierung pur.

Der schrittweise vollzogene und vielleicht auch an einigen Stellen nicht ganz dezidierte Abschied von der Moderne ${ }^{682}$ - in dieser Optik würde ich den letzten Roman Gombrowicz‘ situieren - hat eben einen Text produziert, in dem explizit, quasi hinterfragend, die Frage aufkommt, ,Was kann man wissen?‘

\footnotetext{
${ }^{681}$ Witold Gombrowicz, Tagebuch 1953-1969, München, Wien 1988, S. 158.

${ }^{682} \mathrm{Vgl}$. dazu den bereits von mir erwähnten Włodzimierz Bolecki, der Gombrowicz dezidiert als einen Schriftsteller der Moderne profiliert. Anders als Postmodernisten, suche Gombrowicz nach Bolecki obsessiv nach einem verborgenen Sinn der Wirklichkeit und verwerfe keinesfalls den Glauben an das Subjekt, das Individuum und die Individualität. Włodzimierz Bolecki, Polowanie na postmodernistów, [Die Jagd auf Postmodernisten], Kraków 1999.
} 
Was ist also in Kosmos wirklich passiert? Wurde das Hängen zum Prinzip, hat es sich etwa verselbständigt? Erschöpfte sich das Grebebsen im Sexuellen? Wäre Leon als Witolds Doppelgänger denkbar? Wäre sein Assoziationswahn als Symptom der mentalen Schwäche, z.B. der Paranoia zu deuten oder eher als Simulation einer Ermittlungsstrategie, die bloß nach außen paranoide Züge aufweist? All diese Fragen wird sich jeder um Erkenntnis bemühte Kosmos-Leser stellen müssen und keine von ihnen vermag er zufriedenstellend zu beantworten. Auch in der Makroperspektive lässt sich Kosmos keine klare Botschaft entnehmen. Man könnte lange darüber streiten, ob der Roman die Neuformung, die Neustrukturierung der Wirklichkeit und des Wirklichkeitssinns, ihren/seinen bloßen Zerfall, ihre Privatisierung ${ }^{683}$ oder den Versuch, ,durch die Unwirklichkeit hindurch zur Wirklichkeit zu dringen“6 ${ }^{684}$ zum Ausdruck bringt. Fakt ist dagegen, Kosmos bringt Hierarchien, Ordnungen und die Logik des Diskursiven durcheinander, experimentiert mit der Steigerung der Ästhetisierung und scheint somit in der Postmoderne angekommen zu sein. Die Entdeckung der ästhetisch entgrenzten Textoberfläche für literarisches Tun lässt Gombrowicz vor allen Dingen das Fiasko der Diskursivität ${ }^{685}$ (ohne die jedoch keine Intersubjektivität garantiert werden kann) zum Ausdruck bringen. Problematisiert und erweitert werden aber auch Phänomene wie Unheimlichkeit und Selbstigkeit, deren Inszenierung an der Oberfläche nach neuen Formen und Strategien verlangt.

Da sich die Entgrenzung der Ästhetik m.E. skalieren lässt, würde ich den Roman The Crying of Lot 49 von Thomas Pynchon zwischen dem tastenden Kosmos und dem radikal entgrenzten Lust situieren. Ähnlich wie Gombrowicz‘ letzter Roman stellt CL 49 eine Verschachtelung von Berichten detektivischer Ermittlungen, Erinnerungen, Vermutungen, Analogien und Wortspielen dar. Während jedoch bei Gombrowicz das Geschehen durch die zunehmende Intensität gekennzeichnet ist, sind es bei Pynchon Unmengen von Daten, Namen und Ereignissen, die die Protagonistin und somit den Leser überfluten. Der zunehmend dynamischen mentalen Verarbeitung von Wahrnehmungen und Assoziationen des KosmosErzählers entspricht die wachsende Entdifferenzierung der zu verarbeitenden Daten in $C L 49$. Angesichts der Reizüberflutung wird sich der Leser in erster Linie um eine Strategie des Sortierens und Hierarchisierens der gelieferten Informationen bemühen. Der Informationsfluss scheint jedoch strategisch so manipuliert zu sein, dass die neu eintretenden Figuren nur

\footnotetext{
${ }^{683}$ Vgl. Witold Gombrowicz, Eine Art Testament, S. 30.

${ }^{684}$ Ebd., S. 12.

${ }^{685}$ Dieses Fiasko resultiert eben aus der Entgrenzung des (Literar)Ästhetischen. In Kosmos kommt dies zum Ausdruck, indem Witold seine Wahrnehmungen und Assoziationen vergeblich in die vertraute Logik (d.h. auf dem Weg rational durchgeführten Ermittlungen) hineinzupressen sucht.
} 
so lange in dem Geschehen agieren, bis sie bei dem Leser den Eindruck erwecken, gleich könne er dank ihnen eine sinnhafte Verknüpfung der zahlreichen Indizien erstellen. Ähnlich verhält es sich mit Berichten und Hinweisen, die notorisch in Momenten unterbrochen werden, in denen sie anfangen, das Testamentsgeheimnis Inveraritys ein wenig aufzuklären.

Das sehr gekonnte Manipulieren der Dialektik der Differenzierung und Entdifferenzierung ermöglichte Pynchon noch weitere Fallen anzulegen, die zu interpretatorischen Sackgassen wurden. Es handelt sich nämlich um punktuell erscheinende Momente des Eindringens einer unbekannten Entität ins Wahrnehmungsfeld der Protagonistin. In sich nähernde Offenbarungen gekleidet, scheint Pynchon in dieser Form, dem Undarstellbaren einen literarästhetischen Ausdruck geben zu wollen. Dieses Unterfangen bleibt jedoch wiederholt ohne Erfolg, denn „unmediated revelation may never appear in a body of language.“686 Nochmals wird der Leser mit dem (leeren) Versprechen einer verborgenen Bedeutung gelockt und nochmals vermag er es nicht, (diesmal) den leeren Hierophanien Sinn zu entnehmen.

Die avancierte ,Postmodernität‘ von $C L 49$ lässt sich meines Erachtens an mehreren Stellen des Romantextes ablesen. Es sind nicht nur Probleme epistemologischer Natur, die in der Literatur der Moderne dominierten, sondern auch Fragen der Ontologie, mit denen Pynchons Roman gespickt ist. ${ }^{687}$ Mit der Unmöglichkeit konfrontiert, das Vermächtnis zu vollstrecken, muss die Protagonistin die ihr bisher vertrauten (diskursiven) Erkenntniswege hinterfragen. Ihre, unsicher vor sich hin artikulierte, Frage: „Soll ich eine Welt projizieren?“, markiert eben - so meine These - den Abschied von der Moderne. Angesichts des wiederholten Scheiterns der Erkenntnisstrategien, die Oedipa einzusetzen sucht, um ihre Aufgabe der Testamentsaufklärung zu bewältigen, wagt sie, (vielleicht angesichts der sich nähernden Paranoia) den Gedanken der möglichen Selbstkreierung ihrer Welt und somit die Hervorhebung der privaten Sinnhaftigkeit ${ }^{688}$ in Betracht zu ziehen.

Ähnlich wie Gombrowicz kann auch Pynchon, die Aufmerksamkeit des Rezipienten schrittweise herausfordern. Die klar formulierte Aufgabe der Protagonistin, ihre durchdachte Vorbereitung, das Vermächtnis zu vollziehen, ihre Schritte und Überlegungen, all das macht anfänglich den Eindruck, CL 49 könnte zwar mit der Fülle der Figuren und Hinweisen das Gedächtnis überfordern, diese Irritation sollte jedoch die Lektüre keinesfalls erheblich beeinträchtigen. Die tatsächliche Verwirrung entspringt erst der sich entgrenzenden

\footnotetext{
${ }^{686}$ Peter L. Cooper, Signs and Symptoms, Berkeley, Los Angeles London 1983, S. 204.

${ }^{687}$ Vgl. dazu den mehrmals von mir zitierten Text Brain McHale's Constructing Postmodernism, London, New York 1992.

${ }^{688}$ Pynchon hat somit eben das inszeniert, was Gombrowicz in Kosmos explizit thematisierte, d.h. die Notwendigkeit einer privaten Logik, angesichts der Unzulänglichkeit der Diskursivität.
} 
ästhetischen Ebene der Werkes. Eingeführt wird der nichtssagende Name Tristero, mit einem Symbol des gedämpften Horns versehen, wird es der Protagonistin als das geheime Postsystem vorgestellt. In undurchschaubarer Logik fängt Tristero an, mit jeder neu erscheinenden Figur und mit jedem neuen Ereignis in Verbindung gebracht zu werden. Letztlich symbolisiert es die Haltung der Entgleisten und Entrechteten der Gesellschaft, erweist sich als Name eines Helden in einem blutigen Theaterstück, hat etwas mit den Offenbarungen zu tun, führt zum wahnsinnig gewordenen Psychiater, zum exzentrischen Natur- wissenschaftler, scheint etwas mit der Verzerrung der Kommunikation und dem Konzept der Entropie gemeinsam zu haben. Die permanente Instabilität des Tristero macht es zu einem Signifikanten, dem man fast jede Bedeutung anheften kann, und bildet somit meines Erachtens den wichtigsten Desorientierungsknoten in $C L$ 49. Diese - auf die allmähliche Beraubung der Orientierungspunkte zielende - Strategie lässt sich einleuchtend mit dem Phänomen der Entropie erklären. Grob genommen, handelt es sich dabei um die Wahrnehmung einer Unordnung, und zwar sowohl in der perzipierten Wirklichkeit als auch im Kommunikations- fluss. Die Zunahme an Entropie beschreibt generell ein Phänomen, in dem sich „ein Zusammenprall beziehungsloser Einzelordnungen“689 intensiviert. Dies ist direkt in den Erfahrungen der Protagonistin erkennbar: Oedipa trifft Menschen unterschiedlicher gesellschaftlicher Schichten, die ihr erlauben, einen kurzen Blick in ihre sehr unterschiedliche Umwelten zu werfen. In der Kommunikation mit anderen Figuren sucht sie die gewonnenen Informationen und Hinweise effizient zu sortieren und zu hierarchisieren. Das kann ihr jedoch nicht gelingen, weil die Äußerungen mit denen sie konfrontiert wird, eine sehr zufallshafte Abfolge aufweisen, was mit einer sehr großen Menge an Informationen verbunden ist, ${ }^{690}$ die letztlich viele mögliche Szenarien als gleich wahrscheinlich erscheinen lassen. So gesehen, beraubt die zunehmende Entropie Oedipa orientierungsgebender, ordnender Erkenntnis- strategien. Die allmählich fortschreitende Entdifferenzierung und Enthierarchisierung hindert sie und folglich den Leser konsequent daran, die sie überflutenden Informationen und Ereignisse sinnhaft miteinander verknüpfen zu können. Mit dieser Strategie der Desorientierung ist das gesamte Romangeschehen von $C L 49$ durchtränkt: schablonenhafte Gestaltung der Figuren und das Fehlen der psychologischen Dimension lassen kaum Unterschiede zwischen ihnen feststellen, die ihre Rollen für Oedipas Aufgabe differenzieren ließen. Keiner der im Laufe der Ermittlungen gewonnenen Blickwinkel

\footnotetext{
${ }^{689}$ Rudolf Arnheim, Entropie und Kunst: ein Versuch über die Unordnung und Ordnung, Köln 1979, S. 23.

${ }^{690}$ Vgl. S. $69 f$.
} 
erkämpft das Privileg, relevanter als andere zu sein. Überraschend klar scheint nur noch angesichts der angehäuften Verwirrungen - Oedipas Erkenntnisbilanz auszufallen:

„Entweder: entweder du bist tatsächlich - ohne die Hilfe von LSD [...] auf einen geheimen Schatz, auf eine verborgene Schicht deiner Träume gestoßen, auf ein Nachrichtennetz, über dessen Drähte eine ganz schöne Menge von Amerikanern aufrichtig miteinander kommunizieren kann, während sie ihre Lügen [...] all die Früchte ihrer geistigen Armut, dem offiziellen Verteilersystem der Regierung anvertrauen, vielleicht aber bist du sogar auf eine echte Alternative zu dieser Ausweglosigkeit, zu diesem einförmigen Leben [...], das die Seele jedes Amerikaners zerreißt, den du kennst, und deine eigene auch [...] gestoßen. Oder: oder du bildest dir das alles nur ein. Oder ein Komplott ist gegen dich geschmiedet worden [...] Oder du bildest dir ein solches Komplott nur ein [...] Das waren also jetzt [...] die Alternativen. Diese symmetrischen vier. Keine davon gefiel ihr wirklich, am erträglichsten schien ihr immer noch, geisteskrank zu sein $[\ldots](C L 49,145 f)$

,Diese symmetrischen vier', genauer gesagt, das klare Bewusstsein dieser Erkenntnisbilanz markiert meines Erachtens den (entropischen) Höhepunkt von CL 49 und somit ein perfekt inszeniertes epistemologisches Patt. So formulierte Bestimmung der Lage impliziert das Versagen der Diskursivität und zugleich den Zustand der Desorientierung. ${ }^{691}$ Der einzige Ausweg aus der Unerträglichkeit der Gleichwahrscheinlichkeit mehrerer (Sinn)Optionen, scheint in die (kreative) Paranoia hineinzuführen. Der Leser wird sich dagegen von seinen provisorischen, im Laufe der Lektüre erstellten, Deutungen verabschieden müssen.

Anders als Jelinek bringen Gombrowicz und Pynchon noch das Ringen des Subjekts um die Rettung seiner diskursiven Identität zum Ausdruck. Was sie vor allen Dingen inszenieren, ist jedoch die Invasion, das Eindringen, das Fortschreiten der Entgrenzung des Oberflächlichen, des Ästhetischen. Sowohl Oedipa als auch Witold scheitern angesichts der Fülle der sich ästhetisierenden Wahrnehmungen, sie vermögen weder ihre Identität zu retten noch eine effiziente, ordnende Strategie des Umgangs mit der neuen Wirklichkeit herauszuarbeiten. Es wäre daher nicht verfehlt, diese Strategie als einen spezifisch postmodernen Moment einzustufen. Es handelt sich hier nämlich einerseits um eine explizit formulierte Unmöglichkeit, irgendeiner imaginierten Entität oder Dimension den sprachlichen Ausdruck zu geben. Der Sinn dieser Mitteilung scheint jedoch andererseits kaum verständlich zu sein, wenn die weiten Teile des Romangeschehens, und zwar in allen drei von mir untersuchten Romanen, den Eindruck wecken, dass man hier eben um die Hervorbringung des

\footnotetext{
${ }^{691}$ Nach Heinz Ickstadt mündet die Lektüre von $C L 49$ in eine interpretatorische Agonie. Vgl. Heinz Ickstadt, Thomas Pynchon: Die Versteigerung von Nr. 49, in: Heinz Ickstadt (Hg.), Ordnung und Entropie. Zum Romanwerk von Thomas Pynchon, Reinbek bei Hamburg 1981, S. 111.
} 
Nicht-Diskursiven bemüht sei. Um jeden Preis wird also versucht, das Undarstellbare in Worte, in Sätze zu kleiden, es an der breiten Textoberfläche sichtbar zu machen, die Desorientierung dabei vorprogrammierend. Die einfachsten Methoden finden wir bei Pynchon: Die Daten- und Ereignisüberflutung und die Vermengung von inkompatiblen Begrifflichkeiten ließen eine dermaßen kunterbunte Textoberfläche entstehen, dass ihre intensive Wahrnehmung das Gedächtnis- und das Sinnbildungsvermögen permanent überfordert. Weit raffinierter ist in dieser Hinsicht meines Erachtens die Art Gombrowicz': Irgendwann wird sich der Leser des Eindrucks nicht erwehren können, es wird hier wiederholt das Gleiche erzählt. Dass sich beim genauen Hinsehen das Gleiche als nicht ganz das Gleiche zeigt, kompliziert noch den Eindruck, verschlimmert die Lage des Rezipienten, der zwar zu ahnen beginnt, dass das Gleiche in jeder neu kreierten Konstellation nicht mehr das Gleiche sei, welcher Sinn sich jedoch diesen üppig blühenden Kreationen entnehmen lässt, vermag er keinesfalls herauszufinden. Der Roman Jelineks mag wiederum den Eindruck erwecken, man war hier sehr darum bemüht, einen literarischen Text zu schaffen, der etwas Fremdes aus sich abzuhusten sucht, als ob er sich mit etwas sehr Schlimmen verschluckt hätte. ${ }^{692}$ Diesen Eindruck wusste Jelinek geschickt den ganzen Roman lang aufrechtzuerhalten, auf keiner Textseite scheint Lust zur Ruhe zu kommen.

Da Jelineks Lust wesentlich postmoderner, d.h., wie bereits erwähnt, weit fortgeschrittener ästhetisch entgrenzt ist als Kosmos und $C L 49$, wird sie m.E. ein erheblich größeres Desorientierungspotential entfalten. Dieses konnte auch entsprechend komplex inszeniert werden: starke Fragmentierung des Romantextes, eine irritierend-irreführende Lust-Dialektik, die krasse Verzerrung des Diskurses der Pornografie mit kaum realisierbarer Folge, die wechselnde Identität des Erzählers und chaotische Vermengung von Kommentaren zu unterschiedlichsten thematischen Bereichen, all das macht den Roman Lust zu einem literarischen Beispiel der postmodernen Totalästhetisierung. Die untersuchten Romane Gombrowicz' und Pynchons müssen in dieser Hinsicht als (noch) ziemlich bescheiden erscheinen. Nichtsdestotrotz wissen alle drei Werke ihren Rezipienten gedankliche Peripetien in puncto Verstehen zu bereiten, wenn wir als ,Verstehen“ „die Rekonstruktion von kommunikativer Intention [...] [insbesondere - K.S.] die Rekonstruktion von diskursiven

\footnotetext{
${ }^{692}$ Wenn man diesen Vergleich weiterdenkt, könnte man sich das zu hervorbringende Weibliche als das Abzuhustende denken. In dieser Optik gesehen, braucht das Abzuhustende den männlichen Diskurs, um inn zu schwächen und auszubeuten, um sich auf seine Kosten zu konstituieren und sich in einer möglichst starken Differenz zu ihm begreifen zu können.
} 
Zusammenhängen“693 meinen. Es scheint kaum möglich, diesen literarischen Texten eine eindeutige Absicht (es sei denn die, ihre Rezipienten zu desorientieren) zuzuschreiben, die sich aus der „Ausführung einer zielbezogenen Handlung“ ${ }^{694}$ erkennen ließe. Die Desorientierung wird somit an Orten aufkeimen, an denen das Denken ihre Funktion, d.h. das Hinführen zum Verstehen, nicht mehr erfüllen kann. Oedipa und Witold verstehen sehr gut in den ihnen vertrauten Diskursen. Beginnen aber diese Diskurse (durch das ,Eindringen dessen da draußen“ oder durch die Entgrenzung des Ästhetischen) zu entgleisen, entstehen auch Defizite in den gewohnten Strategien des Verstehens, die um die diskursive Ordnung bemühte Subjekte ordentlich verwirren. Ein wenig anders verhält es sich mit Gerti, die keinerlei Bemühungen um das Verstehen ihrer Lage von sich gibt. Zum bloßen Körper und seinen Bedürfnissen reduziert, erfüllt Gerti nur noch die Rolle eines Zeichens, dessen Bewegung zwischen anderen Zeichen ihre frühere Ordnung durcheinander bringen soll. Die zunehmende Ästhetisierung in ihrem strategischen Einsatz dient in dieser Optik vor allem der Problematisierung des Verstehens und folglich der Bedeutungsbildung (oder auch umgekehrt). Wie verwirrend, erschöpfend und folglich desorientierend das Versteckspiel mit dem Signifikat, nach dem unzählige Signifikanten suchen, sein kann, versuchten meine Untersuchungen zu zeigen. Es ist dadurch m.E. klarer geworden, wie destabilisierend es sich auf die Prozesse der Rationalisierung auswirkt, wenn sich ein Wechsel der Dominante im Ästhetischen vollzieht, d.h. wenn die Ästhetik, die einst die Funktion des Mediums erfüllte, zur Essenz jeder Wahrnehmung avancierte.

Die strategische - auf die Desorientierung des Rezipienten zielende - literarästhetische Entgrenzung hat noch weitere Folgen, die von der Literaturwissenschaft erst benannt/erkannt und untersucht werden müssen. Ich möchte hier noch auf zwei Probleme hinweisen. Es ist in der Postmoderne offenbar geworden, dass wir nicht mehr so lesen und denken (können), wie wir es einst taten. Das Fortschreiten der Ästhetisierung wird m.E. irgendwann zum Eindruck führen, dass Sinn immer weniger fassbar, sondern immer mehr fühlbar wird. Der Sinn koppelt sich allem Anschein nach von der Diskursivität ab und scheint zwischen Lust und Unlust zu zirkulieren. ${ }^{695}$ „As meaning is lost, the materiality of words becomes obsessive ${ }^{696}$ $[\ldots]$

\footnotetext{
${ }^{693} \mathrm{Vgl}$. Fotis Jannidis, Zur kommunikativen Intention. Anfänge, in: Karl Eibl, Katja Mellmann, Rüdiger Zymner (Hg.), Im Rücken der Kulturen, Paderborn 2007, S. 185. Nach Jannidis verstehe ich hier Intention als ,Attribuierungsphänomen“, bei dem „nicht die Intention, die jemand hat, sondern die Intention, die einer einem anderen zuschreibt" untersucht wird. Ebd., S. 190.

${ }^{694}$ Ebd., S. 194.

${ }^{695}$ In dieser Optik scheint Lyotard das Erhabene in der Postmoderne aufzufassen, dessen Quelle er in den Versuchen, das Absolute darzustellen, situiert und diese als ,negative‘ Darstellung bezeichnet: „Das Erhabene
} 
a signifier that has lost its signified has thereby been transformed into an image. ${ }^{697}$ Die postmoderne Kommunikation scheint daher allmählich zu einer Zirkulation von Zeichen zu degenerieren, deren verknappte Sinnhaftigkeit die Versuche tiefgründiger Polemiken zunichtemacht.

Das zweite Problem betrifft die Subversion, deren strategischer Einsatz das explizit Dargestellte, das Oberflächliche, das Herrschende konsequent zu unterlaufen suchte. Die Subversion war immer dazu da, um Schichten der Kommunikation gegeneinander auszuspielen, um das zwischen den Worten Geahnte gegen das in Worten Ausgedrückte einzusetzen. Was lässt sich aber jetzt noch unterlaufen, wenn uns die Totalästhetisierung an der Oberfläche gefangengenommen hat? Wie kann man innerhalb des Ästhetischen irgendetwas in einen Konflikt bringen? Wäre es nicht unsinnig, in der Ära des Dissenses, der zum Markenzeichen der Postmoderne wurde, etwas $\mathrm{zu}$ unterlaufen $\mathrm{zu}$ versuchen? Der Wandel, den das Subversive in der Postmoderne erfahren hat, wird teilweise sichtbar, wenn man es im Kontext des unzuverlässigen Erzählens situiert, d.h. herauszufinden versucht, inwieweit Behauptungen des Erzählers ,als falsch gelten müssen mit Bezug auf das, was in der erzählten Welt der Fall ist. “698 Der unzuverlässige Erzähler konnte dabei sehr oft durch seine Ironie lokalisiert werden, denn

„ironische Kommunikation verdoppelt das Kommunikat zwischen zwei Gesprächspartnern in eine explizite und eine implizite Botschaft. Die implizite Botschaft widerspricht der expliziten und soll vom Hörer als die ,eigentlich gemeinte‘ aufgefaßt werden. [...] Die besonderen Möglichkeiten fiktionaler Texte werden jedoch erst dann genutzt, wenn die doppelte Botschaft der Ironie auf zwei verschiedene Sender verteilt ist. In diesem Fall kommuniziert der unzuverlässige Erzähler eine explizite Botschaft, während der Autor dem Leser implizit,

\footnotetext{
ist kein Gefühl der Lust, sondern eine Mischung von Lust und Unlust. Es gelingt nicht, das Absolute darzustellen - darin liegt die Unlust; doch man weiß, daß es dargestellt werden muß und daß das Vermögen der Empfindungen oder der Bilder über das Sinnlich-Wahrnehmbare (das Bild) das darzustellen hat, was die Vernunft begreifen kann. Und selbst, wenn es ihr nicht gelingt und wir daran leiden, empfinden wir doch eine reine Lust bei dieser Spannung." Jean-François Lyotard, Immaterialität und Postmoderne, Berlin 1985, S. 98f. ${ }^{696}$ ",as in the case when children repeat a word over and over again until its sense is lost and it becomes an incomprehensible incantation." Fredric Jameson, Postmodernism and consumer society, in: Hal Foster (red) Postmodern Culture, London 1985, S. 138.

${ }^{697}$ Ebd. Dieser Effekt ist m. E. besonders oft in Thomas Bernhards Romanen Kalkwerk und Aus/öschung wahrnehmbar.

${ }^{698}$ Matias Martinez, Michael Scheffel, Einführung in die Erzähltheorie, C.H. Beck, München 2005, S. 100. Ich greife hier nur eine Version der literarischen Unzuverlässigkeit auf. Eine detaillierte Untersuchung dieses Phänomens liefern u.a. Veröffentlichungen: Unreliable narration: Studien zur Theorie und Praxis unglaubwürdigen Erzählens in der englischsprachigen Erzählliteratur, hrsg. von Ansgar Nünning, Trier 1998 und Was stimmt denn jetzt?: Unzuverlässiges Erzählen in Literatur und Film, hrsg. von Fabienne Liptay, Yvonne Wolf, München 2005.
} 
sozusagen an dem Erzähler vorbei, eine andere, den Erzählerbehauptungen widersprechende Botschaft vermittelt. “699

Würde ich solche ironisch verdoppelte Kommunikate in den von mir untersuchten Romanen sondieren wollen, so zeigt sich diese Mühe schnell als aussichtslos. Im Fall Kosmos ' wäre der Erzähler, der als Figur an dem Geschehen teilnimmt,

„gegenüber den anderen Figuren nach dem logischen System der literarischen Fiktion nicht privilegiert [...] Selbst in diesen Fällen ist jedoch die Unzuverlässigkeit des Erzählers zumeist auf seine theoretischen Sätze begrenzt, während seine mimetischen Sätze vom Leser weiterhin für notwendig wahr gehalten werden.“700

Die Schwierigkeit, dem kommentierenden Kosmos-Erzähler Unzuverlässigkeit zuzuschreiben, resultiert vor allem aus der Tatsache, dass hier eben das Gegenteil der Fall zu sein scheint; gegenüber dem in mimetischen Sätzen berichtenden und erlebenden Erzähler übernimmt der kommentierende die ordnende und $\mathrm{ab}$ und $\mathrm{zu}$ orientierende Funktion. Von der Unzuverlässigkeit kann hier daher keine Rede sein.

Weitaus komplizierter gestaltet sich aber die Erzählerrede in Jelineks Lust. Da sich in diesem Roman die Identität des Erzählers nicht eindeutig bestimmen lässt und auch seine Distanz zur erzählten Welt keine feste ist, wäre es in dieser Hinsicht sinnvoll, diesen Fall als ein Beispiel des mimetisch unentscheidbaren Erzählens einzustufen. Diese Zuschreibung erweist sich jedoch als problematisch, wenn man bedenkt, dass die Rede des Erzählers eine im Grunde stabile und klar bestimmbare erzählte Welt darstellt. ${ }^{701}$ Der Eindruck der Unzuverlässigkeit wird zwar während der Lust-Lektüre höchst wahrscheinlich erweckt, sein Entstehen wird jedoch nicht der Unentscheidbarkeit in puncto der konkreten Beschaffenheit der erzählten Welt entspringen. Sollten wir solche ,mimetische Unentscheidbarkeit` nur den Erzählerreden zuschreiben, in denen „keine einzige Behauptung des Erzählers [...] in ihrem Wahrheitswert entscheidbar [ist], und keine einzige Tatsache der erzählten Welt [...] definitiv fest[steht] ${ }^{\text {“702 }}$, so ließe sich in keinem der von mir untersuchten Romane diese Art des unzuverlässigen Erzählens finden.

All diese und viele andere, von der postmodernen Literatur hervorgebrachten Phänomene, laufen an den Grenzen des Symbolischen zusammen. Und eben da hat der Prozess seines Ausfransens bereits begonnen. Experimentiert wird mit den Grenzen der sprachästhetischen

\footnotetext{
${ }^{699}$ Matias Martinez, Michael Scheffel, a.a.O., S. $100 f$.

${ }^{700}$ Ebd., S. 101.

${ }^{701}$ Vgl. ebd., S. 103.

${ }^{702} \mathrm{Ebd}$.
} 
Entgrenzung, mit der Wahrnehmung der Ambivalenz, der Indifferenz. Herausgefordert wird jedes Mal die Diskursivität, indem - mit der Elastizität des sprachlichen Materials spielend die Grenzpunkte ihrer Funktionalität gemessen werden. Die Desorientierung scheint in jenem ,dazwischen ${ }^{703}$ aufzukeimen, wo sich ,excluded middle ${ }^{704}$, der Kosmos, das ,Weibliche“ anzusiedeln suchen, wo sie deutlich imaginiert nach einer symbolischen Ausdrucksform Ausschau halten und diese doch nicht finden können. Jede Desorientierung ist jedoch ein Übergangs-, ein Zwischenzustand, der Hinterfragung, Dekonstruktion, Umorientierung der Erkenntnisstrategien initiiert. Eine Neuformierung, sei es der neuen Wirklichkeit, der neuen Denk- und Lesart braucht aber Zeit und eine Reihe enttäuschender Versuche. Die postmoderne Literatur experimentiert gerne mit der ,Logik des Unsinns', den Sinn parodierend $^{705}$, desorientierend und allzu gerne scheint sie ihre Leser dazu zu provozieren, sich einer privaten Logik zu bedienen.

\footnotetext{
${ }^{703}$ Das ,Dazwischen' kennzeichnete die mentale Kondition, die generelle Befindlichkeit Gombrowicz'. Vgl. dazu Witold Gombrowicz, Eine Art Testament, München Wien 1996, S. 8,16,23.

${ }^{704}$ Vgl. dazu meine Anmerkung in der Fn. 150, S. 45 u. Zit. S. 64.

${ }^{705}$ Vgl. Witold Gombrowicz, a.a.O., S. 24.
} 


\section{Literaturverzeichnis}

\section{Primäre Literatur:}

Gombrowicz, Witold: Indizien. Verlag Günther Neske, Pfullingen 1966.

Gombrowicz, Witold: Kosmos. Carl Hanser Verlag, München Wien 1985.

Gombrowicz, Witold: Kosmos. Wydawnictwo literackie, Kraków 1988.

Jelinek, Elfriede: Lust, Rowohlt, Reinbek bei Hamburg 2000.

Pynchon, Thomas: The Crying of Lot 49. Vintage, London 1996.

\section{Sekundäre Literatur:}

Alber, Jan/ Fludernik, Monika (Hg.): Moderne/Postmoderne. Wissenschaftlicher Verlag, Trier 2003.

Arnheim, Rudolf. Entropie und Kunst: ein Versuch über die Unordnung und Ordnung. DuMont, Köln 1979.

Baackmann, Susanne: Erklär mir Liebe. Weibliche Schreibweisen von Liebe in der Gegenwartsliteratur. Argument-Verlag, Hamburg 1995.

Baran i Suszczyński, Kraków 1996. S. 7-21.

Baran, Bogdan: Postnietzsche. Inter Esse, Kraków 2003.

Baran, Bogdan: Postmodernizm i końce wieku. [Der Postmodernismus und die Enden des Jahrhunderts.] Inter Esse, Kraków 2003.

Bartoszyński, Kazimierz: Kosmos i antynomie. [Kosmos und Antynomien.] In: Zdzisław Łapiński (Hg.): Gombrowicz i krytycy Gombrowicz und Kritiker]

Wydawnictwo literackie, Kraków, Wrocław 1984. S. 655-691.

Bartoszyński, Kazimierz: Kryzys czy trwanie powieści. [Die Krise oder das Fortbestehen des Romans.] Universitas, Kraków 2004.

Bearn, Gordon C.F.: Wittgenstein and the Uncanny, Soundings: An interdsiciplinary Journal, vol.76, no.I, (1993).

Berressem, Hanjo: Pynchon's Poetics Interfacing Theory and Text. University of Illinois Press, Urbana, Chicago 1993.

Bode, Christoph: Ästhetik der Ambiguität: zu Funktion und Bedeutung von Mehrdeutigkeit in der Literatur der Moderne. Niemeyer, Tübingen 1988. 
Bohrer, Karl Heinz: Die Grenzen des Ästhetischen. Carl Hanser Verlag, München Wien, 1998.

Bolecki, Włodzimierz: Polowanie na postmodernistów. [Die Jagd auf Postmodernisten.] Wydawnictwo Literackie, Kraków 1999.

Bossinade, Johanna: Poststrukturalistische Literaturtheorie. Verlag J.B. Metzler, Stuttgart Weimar 2000.

Burger, Rudolf: Das Denken der Postmoderne. Würdigung einer Philosophie für Damen und Herren. In: Albert Berger/Gerda Elisabeth Moser (Hg.): Jenseits des Diskurses.

Literatur und Sprache in der Postmoderne. Passagen Verlag, Wien 1994. S. 29-40.

Burger, Rudolf: Der böse der Elfriede Jelinek, In: Gürtler, Christa (Hg.): Gegen den schönen

Schein. Texte zu Elfriede Jelinek. Verlag Neue Kritik, Frankfurt (Main) 1990. S. 17-29. Burzyńska, Anna: Postmoderna: pomiędzy Wieża Babel a Biblioteka Babel. [Zwischen dem Babelturm und der Babelbibliothek.] In: Postmodernizm. Teksty polskich autorów [Die Postmoderne. Die Texte polnischer Autoren.] Bunkier Sztuki inter esse, Kraków 2003. S. 53-78.

Cioran, Emile M.: Der Absturz in die Zeit. Klett-Cotta, Stuttgart 1980.

Cixous, Hélène: The laugh of the Medusa. In: Signs, Vol. 1, No. 4, Chicago 1976. S. 875-893.

Claas, Dietmar: Ein abgekartetes Spiel? Handlungsspiele in Die Versteigerung von No. 49 und die innovative Leistung des Lesers. In: Ickstadt, Heinz (Hg.), Ordnung und Entropie. Zum Romanwerk von Thomas Pynchon. Rowohlt, Reinbek bei Hamburg 1981. S. 128-146.

Cooper, Peter L.: Signs and Symptoms. Berkeley, Los Angeles, London: University of California Press, 1983.

Czabanowska-Wróbel, Anna: Kosmos powtórzeń Witolda Gombrowicza [Der Kosmos der Wiederholungen Witold Gombrowicz'.] In: Jarzębski, Jerzy (Red.): Witold Gombrowicz. Nasz współczesny. [Witold Gombrowicz. Unser Zeitgenosse.] Universitas, Kraków 2010. S. 444-458.

Demmerling, Christoph/ Vendrell Ferran, Íngrid: Philosophie der Literatur. Fragen, Probleme und Perspektiven. In: Demmerling, Christoph/ Vendrell Ferran, Íngrid (Hg.): Wahrheit, Wissen und Erkenntnis in der Literatur. Akademie Verlag, Berlin 2014. S. 7-24.

Dugdale, John: Thomas Pynchon Allusive Parables of Power. MacMillan, Houndmills, Basingstoke, Hampshire, London 1990. 
Feger, Hans (Hg.): Handbuch Literatur und Philosophie. Verlag J.B. Metzler, Stuttgart Weimar 2012.

Fiedler, Leslie A.: Überquert die Grenze, schließt den Graben! In: Wolfgang Welsch (Hg.): Wege aus der Moderne. VCH Acta humaniora, Weinheim 1988. S. 57-74.

Fludernik, Monika: Einführung in die Erzähltheorie. Wissenschaftliche Buchgesellschaft, Darmstadt 2006.

Freese, Peter: From Apocalypse to entropy and beyond: The second law of thermodynamics in Post-War American Fiction. Verlag Die Blaue Eule, Essen 1997.

Freese, Peter: Vom apokalyptischen zum entropischen Ende: Thermodynamik, Informatik und Literatur. Universität Paderborn, Paderborn 2006.

Frege, Gottlob: Über Sinn und Bedeutung. In: Ders. Funktion, Begriff, Bedeutung. Fünf logische Studien. (Hrsg. von Günther Patzig) Vandenhoeck \& Ruprecht, Göttingen 2008. S. 23-46.

Freud, Sigmund: Das Unheimliche (1919) In: Freud, Sigmund: Psychologische Schriften, B. IV. S. Fischer Verlag, Frankfurt am Main 1970. S. 241-274.

Gall, Alfred: Performativer Humanismus. Die Auseinandersetzung mit Philosophie in der literarischen Praxis von Witold Gombrowicz. Thelem, Dresden 2007.

Gall, Alfred: Rozgrywka z filozofia. 'Bycie i czas' Martina Heideggera w maszynerii 'Kosmosu' Witolda Gombrowicza [Eine Spielpartie mit der Philosophie. 'Sein und Zeit' Martin Heideggers in der Maschinerie ,Kosmos ' Witold Gombrowicz '] In: Jarzębski, Jerzy(Red.): Witold Gombrowicz. Nasz współczesny. [Witold Gombrowicz. Unser Zeitgenosse] Universitas, Kraków 2010. S. 352-364.

Gaut, Berys: Art and Knowledge. In: The Oxford Handbook of Aesthetics. Edited by Jerrold Levinson, Oxford 2003, S. 439-444.

Gombrowicz, Witold: Dzieła, t. XIV. [Gesamelte Werke, B. XIV], Wydawnictwo Literackie, Kraków 1997.

Gombrowicz, Witold: Eine Art Testament, Carl Hanser Verlag, München Wien 1996.

Gombrowicz, Witold: Tagebuch 1953-1969, Carl Hanser Verlag, München Wien 1988.

Grant, J. Kerry: A Companion to The crying of Lot 49. Athens: University of Georgia Press, 1994.

Habermas, Jürgen: Der philosophische Diskurs der Moderne. Suhrkamp Verlag, Frankfurt am Main 1985.

Habermas, Jürgen: Die Moderne - ein unvollendetes Projekt. In: Wolfgang Welsch (Hg.): Wege aus der Moderne. VCH Acta humaniora, Weinheim 1988. S. 177-192. 
Harreß, Birgit: Die Dialektik der Form. Das mimetische Prinzip Witold Gombrowiczs. Peter Lang, Frankfurt am Main 2001.

Hartwig, Ina: Schwere Arbeit am Monument des Sexus. Über Elfriede Jelineks Lust. In: Heinz Ludwig Arnold (Hg.): Elfriede Jelinek. Ed. Text+Kritik, H. 117, München 2007. S. 74-84.

Hartwig, Ina: Sexuelle Poetik. Proust Musil Genet Jelinek. Fischer Taschenbuch Verlag, Frankfurt am Main 1998.

Hassan, Ihab: Postmoderne heute. In: Wolfgang Welsch (Hg.), Wege aus der Moderne. VCH Acta humaniora, Weinheim 1988. S. 47-56.

Heidemann-Nebelin, Klaudia: Rotkäppchen erlegt den Wolf. Marieluise Fleißer, Christa Reinig und Elfriede Jelinek als satirische Schriftstellerinnen. Holos Verlag, Bonn 1994. Hill, Robert Ratcliff: Epistemological dilemmas in the works of Norman Mailer and Thomas Pynchon: The themes and motifs of systematization, paranoia and entropy. University of Tulsa, Oklahoma 1981.

Hite, Moly: Ideas of Order in the novels of Thomas Pynchon, Columbus: Ohio State University Press, 1983.

Hoffmann, Gerhard: Das narrative System der Postmoderne und die Auflösung des Charakters im Erzähltext: Die Reduktionsformen von Handeln und Bewußtsein. In: Hoffmann, Gerhard (Hg.): Der zeitgenössische amerikanische Roman: Von der Moderne zur Postmoderne, Bd. 1, Elemente und Perspektiven. Wilhelm Fink Verlag, München 1988. S. 145-224.

Horn, Eva/Menke, Bettine/Menke, Christoph: Literatur als Philosophie - Philosophie als Literatur. Wilhelm Fink Verlag, München 2006.

Höfler, Günther A.: Vergrößerungsspiegel und Objektiv: Zur Fokussierung der Sexualität bei Elfriede Jelinek. In: Bartsch, Kurt/ Höfler, Günther (Hg.): Elfriede Jelinek. Literaturverlag Droschl, Graz,Wien 1991. S.155-172.

Höfler, Günther A.: „,Stop making sense“. Werner Schwabs Pop-Stück,Mesalliance aber wir ficken uns prächtig ' - ein postmodernes Volksstück? In: Berger, Albert/Moser, Gerda Elisabeth (Hg.): Jenseits des Diskurses. Literatur und Sprache in der Postmoderne Passagen Verlag, Wien 1994. S. 323-336.

Hornung, Alfred /Kunow, Rüdiger: Der amerikanische Gegenwartsroman und seine kulturelle Matrix. In: Hoffmann, Gerhard (Hg.): Der zeitgenössische amerikanische Roman: von der Moderne zur Postmoderne, Bd. 1. Elemente und Perspektiven. Wilhelm Fink Verlag, München 1988. S. 45-80. 
Hutcheon, Linda: A Poetics of Postmodernism. History, Theory, Fiction. Routledge, New York, London 1988.

Huyssen, Andreas: Postmoderne - eine amerikanische Internationale. In: Huyssen, Andreas/

Scherpe, Klaus (Hg.), Postmoderne. Zeichen eines kulturellen Wandels. Rowohlt,

Reinbek bei Hamburg 1986. S. 13-44.

Ickstadt, Heinz: Einleitung, In: Ickstadt, Heinz (Hg.): Ordnung und Entropie. Zum

Romanwerk von Thomas Pynchon. Rowohlt, Reinbek bei Hamburg 1981. S. 7-15.

Ickstadt, Heinz: Thomas Pynchon: Die Versteigerung von No.49. In: Ickstadt, Heinz (Hg.):

Ordnung und Entropie. Zum Romanwerk von Thomas Pynchon, Reinbek bei Hamburg 1981. S. 104-127.

Irigaray, Luce: Genealogie der Geschlechter. Kore, Freiburg i. Br. 1989.

Irigaray, Luce: Zur Geschlechterdifferenz. Wiener Frauenverlag, Wien 1987.

Irigaray, Luce: Das Geschlecht das nicht eins ist. Merve Verlag, Berlin 1979.

Irigaray, Luce: Speculum. Suhrkamp, Frankfurt am Main 1980.

Isenschmid, Andreas: Trivialer Roman in experimenteller Tarnung. In: Kurt Bartsch, Günther Höfler (Hg.): Elfriede Jelinek. Literaturverlag Droschl, Graz-Wien 1991. S. 239-243. Jakobson, Roman: Poetik Ausgewählte Aufsätze 1921-1971, Suhrkamp, Frankfurt am Main 1979.

Jameson, Fredric: Postmodernism and consumer society. In: Foster, Hal (red): The AntiAesthetic: essays on postmodern culture. Port Townsend, WA: Bay Press, 1983, S. 127-144.

Jannidis, Fotis: Figur und Person. Beitrag zu einer historischen Narratologie, Walter de Gruyter, Berlin, New York 2004.

Jannidis, Fotis: Zur kommunikativen Intention. Anfänge. In: Eibl, Karl/Mellmann, Katja/ Zymner, Rüdiger (Hg.): Im Rücken der Kulturen. Mentis, Paderborn 2007. S. 185-204. Januszkiewicz, Michał, 'Kosmos' Witolda Gombrowicza a problem nihilizmu europejskiego, ['Kosmos' Witold Gombrowicz ' und das Problem des europäischen Nihilismus] In: Jarzębski, Jerzy(Red.) Witold Gombrowicz. Nasz współczesny. [Witold Gombrowicz. Unser Zeitgenosse] Universitas, Kraków 2010. S. 459-470.

Jarzębski, Jerzy: Gra w Gombrowicza w Gombrowicza [Das Spiel Gombrowicz.] Państwowy Instytut Wydawniczy, Warszawa 1982.

Jarzębski, Jerzy: Pojęcie ,formy ' u Gombrowicza. [Der Begriff der ,Form ' bei Gombrowicz.] In: Łapiński, Zdzisław (Hg.): Gombrowicz i krytycy. [Gombrowicz und Kritiker.] Wydawnictwo literackie, Kraków, Wrocław 1984. S. 313-346. 
Jarzębski, Jerzy: Między kreacja a interpretacją. [Zwischen Kreation und Interpretation.] In: Gombrowicz filozof. [Gombrowicz ein Philosoph.] Wydawnictwo ZNAK, Kraków 1991. S. 177-205.

Jauß, Hans Robert: Der literarische Prozeß des Modernismus von Rousseau bis Adorno. In: Studien zum Epochenwandel der ästhetischen Moderne. Suhrkamp Verlag, Frankfurt am Main 1989. S. 67-103.

Jelinek, Elfriede/Heinrich, Jutta/Meyer, Adolf-Ernst: Sturm und Zwang. Schreiben als Geschlechterkampf. Ingrid Klein Verlag, Hamburg 1995.

Kalin, Arkadiusz: Chaos Kosmosu Gombrowicza. [Das Chaos des Kosmos ' Gombrowicz'] In: Jarzębski, Jerzy(Red.): Witold Gombrowicz. Nasz współczesny. [Witold Gombrowicz. Unser Zeitgenosse] Universitas, Kraków 2010. S. 425-443.

Karpiński, Wojciech: Gombrowiczowska przestrzeń [Der Gombrowiczsche Raum] In: Łapiński, Zdzisław (Hg.): Gombrowicz i krytycy. [Gombrowicz und Kritiker] Wydawnictwo literackie, Kraków Wrocław 1984. S. 171-183.

Kępiński, Tadeusz: Witold Gombrowicz. Studium portretowe drugie. [Witold Gombrowicz. Das zweite Porträtstudium.] Wydawnictwo Alfa, Warszawa 1992.

Klepper, Martin: Pynchon, Auster, De Lillo. Die amerikanische Postmoderne zwischen Spiel und Rekonstruktion. Campus Verlag, Frankfurt/Main, New York 1996.

Kletterhammer, Sieglinde: Welcome to Pornotopia? Literarische Sexualästhetik und Skandal seit 1968. In: Neuhaus, Stefan/ Holzner, Johann (Hg.): Literatur als Skandal FälleFunktionen-Folgen. Vandenhoeck \& Ruprecht, Göttingen 2007. S. 412-428.

Koch, Gertrud: Sittengemälde aus einem röm. kath. Land. Zum Roman Lust. In: Gürtler, Christa (Hg.): Gegen den schönen Schein. Texte zu Elfriede Jelinek. Verlag Neue Kritik, Frankfurt (Main) 1990. S. 135-141.

Kolbuszewska, Zofia: The poetics of chronotope in the novels of Thomas Pynchon. Society of the Catholic University of Lublin, Lublin 2000.

Korwin-Piotrowska, Dorota: Powiedzieć świat. Kognitywna analiza tekstów literackich na przykładach. [Die Welt sagen. Kognitive Analyse literarischer Texte mit Beispielen.] Universitas, Kraków 2006.

Kristeva, Julia: Die Revolution der poetischen Sprache. Suhrkamp, Frankfurt am Main 1987. Kühl, Olaf: Stilistik einer Verdrängung. Zur Person von Witold Gombrowicz (Diss.) Freie Universität Berlin, Berlin 1995.

Lachmann, Renate: Thesen zu einer weiblichen Ästhetik, In: Opitz, Claudia (Hg.): Weiblichkeit oder Feminismus? Drumlin Verlag, Weingarten 1984. S. 181-194. 
Lahann, Birgit: Männer sehen in mir die große Domina. In: Stern 37 (8.9.1988).

Legierski, Michał: Modernizm Witolda Gombrowicza. [Modernismus Witold Gombrowicz'], Instytut badań literackich, Warszawa 1999.

Lersch, Barbara: Der Ort der Leerstelle. Weiblichkeit als Poetik der Negativität und der Differenz. In: Brinker-Gabler, Gisela (Hg.): Deutsche Literatur von Frauen, Bd. 2. Verlag C.H. Beck, München 1988. 487-502.

Lyotard, Jean-François: Das postmoderne Wissen. Edition Passagen, Graz Wien 1986. Lyotard, Jean-François: Essays zu einer affirmativen Ästhetik. Merve-Verlag, Berlin 1982. Lyotard, Jean-François: Immaterialität und Postmoderne. Merve Verlag, Berlin 1985. Łapiński, Zdzisław: Postmodernizm - co to i po co? [Die Postmoderne - Was ist das und wozu?] In: Teksty Drugie [Zweite Texte] Nr.1 (1993). S. 74-86.

Mangel, Anne: Maxwell's demon, entropy, information: The Crying of Lot 49, In: George Levine, David Leverenz (ed.): Mindful Pleasures Essays on Thomas Pynchon. Boston, Toronto: Little, Brown and Company, 1976. S. 87-100.

Markowski, Michał Paweł: Czarny nurt Gombrowicz, świat, literatura. [Die schwarze Strömung Gombrowicz, Welt, Literatur] Wydawnictwo Literackie, Kraków 2004. Martinez, Matias/ Scheffel, Michael: Einführung in die Erzähltheorie. C.H. Beck, München 2005.

Masanek, Nicole: Männliches und weiblicher Schreiben? Zur Konstruktion und Subversion in der Literatur. Königshausen und Neumann, Würzburg 2005.

Mc Hale, Brian: Postmodernist Fiction. Routledge, London and New York 1987.

McHale, Brian: Constructing Postmodernism, London, New York: Routledge, 1992.

McHale, Brian: Postmodernist Fiction, London and New York: Routledge, 1987.

Medoro, Dana: Menstruation and Melancholy: The Crying of Lot 49. In: Abbas, Niran (ed.): Thomas Pynchon: Reading from the margins. Madison, NJ: Fairleigh Dickinson University Press, 2003. S. 71-90.

Megill, Allan: Prophets of Extremity. Nietzsche, Heidegger, Foucault, Derrida. University of California Press, Berkeley,Los Angeles,London 1985.

Meyer, Anja: Elfriede Jelinek in der Geschlechterpresse. ,Die Klavierspielerin ' und ,Lust ' im printmedialen Diskurs. Olms-Weidmann, Hildesheim, Zürich, New York 1994.

Meyer, Eva: Vorspiel: Annäherung an eine andere Schreibweise. In: Brigitte Wartmann (Hg.), Weiblich-Männlich. Kulturgeschichtliche Spuren einer verdrängten Weiblichkeit Ästhetik und Kommunikation Berlin 1980. S. 62-76. 
Moser, Gerda Elisabeth: Die Funktion der Sprache in der österreichischen postmodernen

Literatur. In: Berger, Albert/Moser, Gerda Elisabeth (Hg.): Jenseits des Diskurses.

Literatur und Sprache in der Postmoderne. Passagen Verlag, Wien 1994. S. 233-250.

Mustroph, Tom: Lektüren. Von der Autorintention hin zur freien Semiose. Schleiermacher-

Gadamer-Iser-Derrida. Pynchon-Kundera-Jelinek. Tectum Verlag, Marburg 2000.

Neureuter, Elisabeth: Ordnung und Chaos in amerikanischen Romanen nach 1960. Joseph

Heller Catch 22, John Barth Giles Goat-Boy, Thomas Pynchon Gravity's Rainbow.

Universität Regensburg, Regensburg 2001.

Nietzsche, Friedrich: Die Geburt der Tragödie. Hrsg. von Giorgio Colli und Mazzimo

Montinari. dtv, de Gruyter, München 1999.

Norris, Christopher: Deconstruction and the 'Unfinished Project of Modernity'. The Athlone Press, London 2000.

Nycz, Ryszard (Red.): Odkrywanie modernizmu. [Das Entdecken des Modernismus '.]

Universitas, Kraków 1998.

Nycz, Ryszard (Red.): Postmodernizm. Antologia przekładów (Przedmowa). [Die

Postmoderne. Die Antologie der Textübersetzungen (Vorwort).] Wydawnictwo

Wydawnictwo Baran i Suszczyński, Kraków 1996. S. 7-21.

Nycz, Ryszard: Sylwy wspótczesne. Problem konstrukcji tekstu. [Die zeitgenössischen Silven. Das Problem der Textkonstruktion], Ossolineum, Wrocław Warszawa Kraków Gdańsk Łódź 1984.

Okłot, Michał: ,Możliwość fantasmagorii z hipopotamami', czyli obraz materii u Gombrowicza. [ 'Die Möglichkeit der Phantasmagorie mit den Nilpferden', d.h. das Bild der Materie bei Gombrowicz] In: Jarzębski, Jerzy (Red.): Witold Gombrowicz. Nasz współczesny. [Witold Gombrowicz.Unser Zeitgenosse] Universitas, Kraków 2010. S. 392-406.

Okopień-Sławińska, Aleksandra: Wielkie bergowanie, czyli hipoteza jedności 'Kosmosu' [Das große Grebebsen oder die Hypothese der Einheit von 'Kosmos'] In: Łapiński, Zdzisław (Hg.): Gombrowicz i krytycy.[Gombrowicz und Kritiker] Wydawnictwo literackie Kraków Wrocław 1984. S. 693-706.

Olejniczak, Józef: W kosmosie 'Kosmosu'. Opowiem (wam) przygodę ... Witold Gombrowicz [Über den Kosmos des 'Kosmos'“. Ich erzähle (euch) ein Abenteuer... Witold

Gombrowicz] In: Jarzębski, Jerzy (Red.): Witold Gombrowicz. Nasz współczesny.

[Witold Gombrowicz. Unser Zeitgenosse] Universitas, Kraków 2010. S. 365-377.

Peters, Uwe Henrik: Lexikon Psychiatrie Psychotherapie Medizinische Psychologie. Urban \& 
Fischer, München Jena 2007.

Picicci, Annibale: Noise Culture. Kultur und Ästhetik des Rauschens in der Informationsgesellschaft am Beispiel von Thomas Pynchon und Don DeLillo. John F. Kennedy Institut für Nordamerikastudien, Berlin 2001.

Poirier, Richard: The Importance of Thomas Pynchon, In: Harold Bloom (ed.), Thomas Pynchon. New York, New Haven, Philadelphia: Chelsea House Publishers, 1986. S. 47-58.

Potocka, Maria Anna: Manieryzm po modernizmie. [Manierismus nach der Moderne] In: Postmodernizm. Teksty polskich autorów. [Die Postmoderne. Die Texte polnischer Autoren.] Bunkier Sztuki inter esse, Kraków 2003. S. 131-155.

Prechtl, Peter/Burkard, Franz-Peter (Hg.): Metzler Philosophie Lexikon. Begriffe und Definitionen. Verlag J.B. Metzler, Stuttgart-Weimar 1999.

Presber, Gabriele: Die Kunst ist weiblich. Droemer Knaur, München 1988.

Preston, Alison T.J.: Humor and Decentered Meaning in Lot 49. In: Schaub, Thomas Approaches to Teaching Pynchon's The Crying of Lot 49 and Other Works. New York: The Modern Language Association of America 2008. S. 76-82.

Raddatz, Fritz J.: Verwerfungen. Sechs literarische Essays. Suhrkamp, Frankfurt am Main, 1972.

Rasper, Christiane: „Der Mann ist immer bereit und freut sich auf sich. “ Die satirische Inszenierung des pornographischen Diskurses. In: Interdisziplinäre Forschungsgruppe Frauenforschung, Liebes- und Lebensverhältnisse. Sexualität in der feministischen Diskussion, Campus Verlag, Frankfurt am Main, New York 1990. S. 121-140.

Reicher, Maria E.: Können wir aus Fiktionen lernen? In: Demmerling, Christoph/ Vendrell Ferran, Íngrid (Hg.): Wahrheit, Wissen und Erkenntnis in der Literatur. Akademie Verlag, Berlin 2014. S. 73-96.

Ritz, German: Kosmos albo strach przed Pałuba. Metafikcyjna lektura ostatniej powieści Gombrowicza [Kosmos oder die Angst vor Pałuba. Metafiktionale Lektüre des letzten Romans Gombrowicz'] In: Zybura, Marek (Hg.): ,Patagończyk w Berlinie“ Witold Gombrowicz w oczach krytyki niemieckiej. [ 'Ein Patagonier in Berlin' Witold Gombrowicz in den Augen der deutschen Kritik] Universitas, Kraków 2004. S. 513-530. Royle, Nicolas: The Uncanny. Manchester University Press, Manchester, New York, 2003 Saariluoma, Liisa: Der postindividualistische Roman. Königshausen und Neumann, Würzburg 1994.

Safranski, Rüdiger: Nietzsche Biographie seines Denkens. Hanser Verlag, München 2000. 
Scharang, Michael: Lebenselixier auf dem Misthaufen. Zu Elfriede Jelineks „Lust“.

In: Literatur Konkret H. 14, Gremliza Verlag, Hamburg 1989.

Schaub, Thomas: Pynchon: the voice of ambiguity. Urbana: University of Illinois Press, 1981.

Scherpe, Klaus R.: Dramatisierung und Entdramatisierung des Untergangs - zum ästhetischen Bewußtsein von Moderne und Postmoderne. In: Huyssen, Andreas/ Scherpe, Klaus R. (Hg.): Postmoderne. Zeichen eines kulturellen Wandels. Rowohlt, Reinbek bei Hamburg 1986. S. 270-301.

Schlich, Jutta: Phänomenologie der Wahrnehmung von Literatur. Am Beispiel von Elfriede Jelineks Lust (1989). Max Niemeyer Verlag Tübingen 1994.

Schmid, Wolf: Elemente der Narratologie. Walter de Gruyter, Berlin, New York 2008.

Schmid-Bortenschlager, Sigrid: Der analytische Blick. In: Carine Kleiber, Erika Tanner (Hg.) Frauenliteratur in Österreich von 1945 bis heute. Peter Lang, Bern, Frankfurt am Main, New York 1986. S. 109-129.

Schmidt, Siegfried J.: Ästhetische Prozesse: Beiträge zu einer Theorie der nicht-mimetischen Kunst und Literatur. Kiepenheuer \& Witsch, Köln 1971.

Schmidt-Dengler, Wendelin: Werner Kofler. In: Berger, Albert/Moser, Gerda Elisabeth (Hg.): Jenseits des Diskurses. Literatur und Sprache in der Postmoderne Passagen Verlag, Wien 1994. S. 295-308.

Schober, Wolfgang H.: Erzähltechniken in Romanen: Eine Untersuchung erzähltechnischer Probleme in zeitgenössischen Romanen (Diss.) Akad. Verl.-Ges. Athenaion, Wiesbaden 1975.

Schönau, Walter: Einführung in die psychoanalytische Literaturwissenschaft. J.B. Metzler Verlag, Stuttgart 1991.

Sławiński, Janusz: Teksty i teksty. [Texte und Texte] Wydawnictwo PEN, Warszawa 1990. Schwab, Gabriele: Entgrenzungen und Entgrenzungsmythen: zur Subjektivität im modernen Roman; Daniel Defoe, Herman Melville, Virginia Woolf, James Joyce, Samuel Beckett, Thomas Pynchon. Steiner, Stuttgart 1987.

Schwab, Gabriele: Entgrenzungen und Entgrenzungsmythen: zur Subjektivität im modernen Roman; Daniel Defoe, Herman Melville, Virginia Woolf, James Joyce, Samuel Beckett, Thomas Pynchon. Steiner, Stuttgart 1987.

Schwab, Werner: Vernichten, ohne sich anzupatzen, Interview mit R. Koberg und K. Nüchtern. In: Falter (Wien) 40 (1992) S. 2-5. 
Sheppard, Richard: The Problematics of European Modernism. In: Steve Giles (editor):

Theorizing Modernism. Essays in critical theory. Routledge, London, New York 1993. S. 1-51.

Slade, Joseph W.: Thomas Pynchon. Peter Lang, New York, Bern, Frankfurt am Main, Paris 1990.

Stefan, Verena: Häutungen : autobiografische Aufzeichnungen, Gedichte, Träume, Analysen. Verlag Frauenoffensive, München 1975.

Stephan, Inge/Weigel, Sigrid (Hg.): Feministische Literaturwissenschaft, Argument Verlag, Berlin 1984.

Šlibar, Neva: Anschreiben gegen das Schweigen. Robert Schindel, Ruth Klüger, die Postmoderne und die Vergangenheitsbewältigung. In: Berger, Albert/Moser, Gerda Elisabeth (Hg.): Jenseits des Diskurses. Literatur und Sprache in der Postmoderne. Passagen Verlag, Wien 1994. S. 337-356.

Tanner, Tonny: City of Words. American Fiction 1950-1970, London: Jonathan Cope, 1971. Thompson, Ewa: Witold Gombrowicz. Twayne, Boston 1979.

Ulfig, Alexander: Lexikon der philosophischen Begriffe. Fourier Verlag, Wiesbaden 1997. Weber, Ingeborg: Den Bahn der patriarchalen Spiegel-Logik brechen, dem weiblichen Begehren eine Chance: Luce Irigaray und das Konzept des parler femme. In: Weber, Ingeborg (Hg.), Weiblichkeit und weibliches Schreiben. Poststrukturalismus. Weibliche Ästhetik. Kulturelles Selbstverständnis., Wissenschaftliche Buchgesellschaft, Darmstadt 1994.

Weigel, Sigrid: Das Schreiben des Mangels als Produktion von Utopie. In: Hassauer, Friederike/Roos, Petet (Hg.), Die Frauen mit Flügeln die Männer mit Blei?, Affolderbach \& Strohmann Verlag, Siegen 1986.

Weigel, Sigrid: Die Stimme der Medusa. Schreibweisen in der Gegenwartsliteratur von Frauen. tende, Dülmen-Hiddingsel 1995.

Welsch, Wolfgang: Ästhetisches Denken. Reclam, Stuttgart 1990.

Welsch, Wolfgang: Grenzgänge der Ästhetik. Reclam jun., Stuttgart 1996.

Welsch, Wolfgang: Unsere postmoderne Moderne. VCH, Acta humaniora, Weinheim 1987.

Wiener, Norbert: The Human Use of Human Beings: Cybernetics and Society. Houghton Mifflin, Boston 1950.

Wilkiewicz, Zbigniew: Eine Entdeckung. Die Prosa Witold Gombrowicz' in der deutschsprachigen Presse, In: Kneip, Heinz/Orłowski, Hubert (Hg.): Die Rezeption der polnischen Literatur im Deutschsprachigen Raum und die der Deutschsprachigen in Polen 
1945-1985. Deutsches Polen-Institut, Darmstadt 1988. S. 160-173.

Wilkiewicz, Zbigniew: Personendarstellung und Menschbild im ,Kosmos 'Witold Gombrowiczs. Liber Verlag, Mainz 1986.

Wirtz, Markus: Schnittstellen und Demarkationslinien literarischer und philosophischer

Textualität. In: Roussel, Martin/Wirtz, Markus/Wunderlich, Antonia (Hg.):

Eingrenzen und Überschreiten: Ver-fahren in der Moderneforschung. Königshausen \& Neumann, Würzburg 2005. S. 231-246.

Wittgenstein, Ludwig: Bemerkungen über die Philosophie der Psychologie. Letzte Schriften über die Philosophie der Psychologie. Suhrkamp, Frankfurt am Main, 1989.

Wojda, Dorota: Niegrzeczny Gombrowicz. O kommunikacji ponad regułami. [Der unartige Gombrowicz. Über Kommunikation außerhalb der Regeln] In: Jarzębski, Jerzy (Red.): Witold Gombrowicz. Nasz współczesny. [Witold Gombrowicz.Unser Zeitgenosse] Universitas, Kraków 2010. S. 714-726.

Wolf, Werner: Ästhetische Illusion und Illusionsdurchbrechung in der Erzählkunst. Theorie und Geschichte mit Schwerpunkt auf englischem illusionsstörenden Erzählen. Max Niemeyer, Tübingen 1993.

Zalewski, Andrzej: Strategiczna dezorientacja. Perypetie rozumu w fabularnym filmie postmodernistycznym. [Strategische Desorientierung. Peripetien der Vernunft im postmodernen Spielfilm.] Instytut Kultury, Warszawa 1998.

Zapf, Hubert: Postmoderne Literaturtheorie, In: Hans Vilmar Geppert, Hubert Zapf (Hg.): Theorien der Literatur Grundlagen und Prinzipien, Bd. 2. Francke Verlag, Tübingen 2005. S. 206-224.

Zawadzki, Andrzej: Gombrowicz a myśl słaba. [Gombrowicz und das schwache Denken] In: Jarzębski, Jerzy (Red.): Witold Gombrowicz. Nasz współczesny. [Witold Gombrowicz. Unser Zeitgenosse] Universitas, Kraków 2010. S. 129-137.

Zima, Peter V.: Moderne/Postmoderne: Gesellschaft, Philosophie, Literatur. Francke Verlag, Tübingen Basel 1997.

Zima, Peter V.: Moderne/Postmoderne: Gesellschaft, Philosophie, Literatur. Francke Verlag, Tübingen Basel 2001.

Zima, Peter V.: Ästhetische Negation. Das Subjekt, das Schöne und das Erhabene von Mallarmé und Valéry zu Adorno und Lyotard. Königshausen \& Neumann, Würzburg 2005.

Zima, Peter V.: Das literarische Subjekt: Zwischen Spätmoderne und Postmoderne. Francke Verlag, Tübingen und Basel 2001. 


\section{Weblinks:}

http://de.wikipedia.org/wiki/Sender-Empf\%C3\%A4nger-Modell (Stand: 9. Sep. 2013)

http://www.youtube.com/watch?v=4VSOLR5iIMU (Stand: 9. Sep. 2013)

http://www.vonfintel.de/texte/geisteswissenschaft/jelinek.htm (Stand: 12. Sep. 2013)

http://www.deutschlandradiokultur.de/literatur-vs-philosophie-wovon-man-nicht-sprechen

kann.2162.de.html?dram:article_id=320732 (Stand: 21. Dez. 2015) 